Sávia Gavazza dos Santos

\title{
UTILIZACÃO DE METANOL, ETANOL E METANO COMO DOADORES DE ELÉTRONS PARA A DESNITRIFICAÇÃO
}

Tese apresentada à Escola de Engenharia de São Carlos da Universidade de São Paulo, como parte dos requisitos para a obtenção do Título de Doutor em Engenharia Civil área: Hidráulica e Saneamento.

Orientador: Prof. Tit. Eugenio Foresti

São Carlos 
Dedico este trabalho à minha família, meu pai Luiz e minhas irmãs Virgínia, Clarice e Luciana, ao meu amor Eduardo Massao, ao meu mestre Eugenio Foresti e à minha mãe, meu exemplo de vida, que já não está mais de corpo presente entre nós, mas que, certamente, está sempre comigo. 


\section{AGRADECIMENTOS}

Ao Prof. Eugenio Foresti, pela excelente orientação, ensinamentos, conselhos, carinho e amizade, por ser o meu gigante e um exemplo de profissional e de ser humano que levarei para a minha vida. Pessoa melhor, certamente, não haveria para me fazer compreender sobre os fundamentos da Biotecnologia Anaeróbia.

Ao Prof. Marcelo Zaiat, por ter me ensinado a gostar de cinética, pela constante dedicação e contribuição à este trabalho, seja no laboratório, na correção de artigos ou no ajuste de modelos cinéticos. Por seus ensinamentos e seu exemplo que tanto contribuíram para a minha formação profissional.

À Profa. Maria Bernadete Varesche, por ter me acolhido na microbiologia e apostado nesse trabalho. Por ter ensinado a Engenheira Civil a olhar para uma lâmina cheia de bichinhos e dizer: Nossa, que lindo!

À Profa. Rosana Vazoller por ter proporcionado, de maneira muito gratificante, meu primeiro contato com a microbiologia. $\mathrm{O}$ amor com que conduz o seu trabalho serve de grande exemplo para mim.

À Dra. Isabel Kimiko Sakamoto, grande companheira nas análises de Biologia Molecular, pessoa sem a qual, os resultados de DGGE não teriam sido alcançados.

As mulheres mais importantes da minha vida, minhas queridas irmãs Clarice e Luciana e minha tia Sônia, por terem cuidado tão bem do Painho, enquanto eu estive em São Carlos, por serem meu exemplo e meu porto seguro. À vocês, a minha eterna gratidão... Aos homens mais importantes da minha vida, meu pai Luiz e meu amor Massao, pelo incentivo, paciência e por depositarem, quase que diariamente, uma dose de confiança em mim, o que me deu forças para seguir em frente.

Aos doutores Nélia e Márcio Callado, por serem os responsáveis pela minha vinda para São Carlos. Pessoas por quem eu tenho grande admiração e respeito.

A doutora Rosângela Sampaio Reis, pelo incentivo constante e ameaças de extradição caso eu retornasse para Maceió sem o título de doutora.

À minha família em São Carlos, por terem me acolhido com muito amor e carinho, principalmente nos momentos em que eu mais senti falta de casa, como nos almoços de domingo, Páscoa, Natal, nos dias de frio e nas noites de asma: Karina Querne de 
Carvalho; Janete e Débora Foresti; Madalena, Larissa, Siomara, Adriane e Anelise Olmo.

Aos grandes amigos Giovana Wiecheteck, Alessandra Bragança e Fernando Baptistella, pelo apoio diário, incentivo e pelos prazerosos momentos de lazer, tão importantes por servirem como repositores de energia para os momentos de trabalho.

Às pessoas que me ajudaram a entender um monte de coisa sobre análises físicoquímicas e cromatografia, Beth, Janja e Ana Paula Paim, pela amizade, carinho e disposição com que sempre me auxiliaram durante a execução da parte experimental.

Aos funcionários Eloísa, Paulo, Júlio, Flávia, Fernanda, Paví, Sá, Márcia, Valderez, Cecília, Rose, Valdeci, André, Vagner e D. Terezinha pela responsabilidade com que executam suas funções, o que tornou o meu trabalho mais gratificante.

As queridas Alessandra e Loren, da diretoria, pela excelente qualidade do trabalho prestado.

Aos alunos de iniciação científica Alexandre e Aline pela ajuda na realização dos perfis “temporais".

Ao time de vencedores do LPB, pela enriquecedora troca de conhecimentos e por terem tornado muito agradável o ambiente de trabalho e o dia-a-dia naquele laboratório: Rogers, Samantha, Gica, Luiz Ricardo, Valquíria, Márcio Barbosa, Selma, Douglas, Katt, Luiz Hamilton, Betão, Neyson, Fazolo, Marilu, Ivana, Luciana, Flavinha, Gunther, Hélio, Andréa, Estela, Dirlane, Luana, Júlia, Iolanda, Edu, Leonídia, Mércia, Bruna, Dalva, Fernandão, André, Moacir e Ana Paula Miqueleto.

Aos amigos que de forma indireta tiveram participação nesse trabalho: Jucélia, Monique, Paola, Cáscia, Kátia, João, João Rodrigo, Luciana, Madalena, Adelena, Paulo Centurione, Pedro Ivo, Leonardo Vieira, Leonardo Barra, Flávio e Thiago.

À CAPES pela bolsa de mestrado concedida.

À FAPESP, pela bolsa de doutorado direto concedida e pelo apoio financeiro através do Projeto Temático processo nº 2001-05489-0. 
"A mente que se abre a uma nova idéia, jamais voltará ao seu tamanho original”

Albert Einstein 


\section{LISTA DE FIGURAS}

FIGURA 1 - Sistema de transporte de elétrons envolvido na desnitrificação $\quad 7$

FIGURA 2 - Fluxograma dos experimentos realizados 23

FIGURA 3 - Esquema dos reatores anóxicos 25

FIGURA 4 - Foto dos reatores no interior da câmara $\quad 25$

FIGURA 5 - Foto do exterior da câmara climatizada 25

FIGURA 6 - Esquema ilustrativo das condições de operação dos reatores anóxicos comparativos 26

FIGURA 7 - Frascos tipo erlenmeyer utilizados nos ensaios para determinação de parâmetros cinéticos intrínsecos

FIGURA 8 - Reatores anóxicos utilizados nos ensaios de desnitrificação com metano 31

FIGURA 9 - Esquema ilustrativo das variações nutricionais 31

FIGURA 10 - Esquema ilustrativo das amostras incubadas no ensaio de purificação 33

FIGURA 11 - Reator desnitrificante com cultura purificada, amostra MMO3 36

FIGURA 12 - Resultados do monitoramento do reator alimentado com etanol (RE) para $\mathrm{C} / \mathrm{N}=1,0$

FIGURA 13 - Resultados do monitoramento do reator alimentado com metanol (RM1) para $\mathrm{C} / \mathrm{N}=1,0$

FIGURA 14 - Resultados do monitoramento do reator alimentado com metano/ar (50\%/50\%) - (RM2)

FIGURA 15 - Perfis de concentração de nitrato e nitrito, nas fases de adaptação (A) e de biomassa adaptada (B) para os diferentes doadores de elétrons

FIGURA 16 - Consumo das fontes de carbono metanol e etanol, associados aos perfis temporais de concentração de nitrato (fase B)

FIGURA 17 - Perfis temporais de velocidade de consumo de nitrato e nitrito, para os reatores

FIGURA 18 - Concentrações de nitrato e de nitrito, no efluente do reator RM1 $(C / N=0,75)$

FIGURA 19 - Concentrações de nitrato e de nitrito, no efluente do reator RM2 (ausência de oxigênio)

FIGURA 20 - Perfis de concentração de nitrato, nitrito, metanol e etanol na fase C para os reatores

FIGURA 21 - Velocidade de conversão de nitrato, na fase $C(C / N=0,75)$

FIGURA 22 - Concentrações de nitrato e nitrito, no efluente do reator RM1(relação $\mathrm{C} / \mathrm{N}=$ $0,5)$

FIGURA 23 - Perfis temporais de concentração de nitrato, nitrito, metanol e etanol, para a relação $\mathrm{C} / \mathrm{N}=0,5$ (fase $\mathrm{D}$ ), nos reatores

FIGURA 24 - Velocidade de conversão de nitrato, nas fases A, B, C e D, para os doadores de elétrons Metanol e Etanol

FIGURA 25 - Principais morfologias observadas através de microscopia óptica comum e fluorescência

FIGURA 26 - Morfologias observadas em microscopia eletrônica de varredura (MEV)

FIGURA 27 - Diversidade de microrganismos pertencentes ao Domínio Bacteria nas amostras do inóculo (In) e dos reatores RE, RM1 e RM2, na fase B 
FIGURA 28 - Diversidade de microrganismos pertencentes ao Domínio Archaea nas amostras do inóculo (In) e dos reatores RE, RM1 e RM2, na fase B

FIGURA 29 - Diversidade de microrganismos pertencentes ao Domínio Bacteria nas amostras do inóculo (In) e dos reatores E e M1, nas fases B, C e D

FIGURA 30 - Diversidade de microrganismos pertencentes ao Domínio Bacteria nas amostras do inóculo (In) e dos reatores RE e RM1, nas fases B, C e D

FIGURA 31 - Diversidade de microrganismos pertencentes ao Domínio Archaea nas amostras do inóculo (In) e dos reatores RE e RM1, nas fases B, C e D

FIGURA 32 - Perfis temporais de concentração de nitrato, nitrito, $\mathrm{N}_{2} \mathrm{O}$, metanol e etanol obtidos, para a fase $\mathrm{B}$, nos reatores para estudo cinético

FIGURA 33 - Perfil temporal de concentração de nitrato e nitrito obtidos, para a fase $C$, no reator especial alimentado com etanol.

FIGURA 34 - Ajuste de modelo cinético aos perfis temporais de concentração de nitrato, nitrito e $\mathrm{N}_{2} \mathrm{O}$ nos reatores $\mathrm{M}, \mathrm{MO}, \mathrm{MM}, \mathrm{MMO}$ e $\mathrm{C}$

FIGURA 35 - Velocidades de conversão de nitrato e de nitrito - Reator M

FIGURA 36 - Morfologias observadas por meio de microscopia eletrônica de varredura (MEV): (a) bacilos em matriz polímero, encontrados no reator MM e (b) Bacilos e bacilos em cadeia na superfície do grânulo do reator MO.

FIGURA 37 - Morfologias observadas por meio de microscopia óptica comum

FIGURA 38 - Diversidade de microrganismos pertencentes ao Domínio Bacteria nas amostras do inóculo (In) e dos reatores C, M, MO, MM e MMO

FIGURA 39 - Diversidade de microrganismos pertencentes ao Domínio Archaea em amostras do inóculo (In) e reatores C, M, MO, MM e MMO

FIGURA 40 - Morfologias observadas em aumento da massa celular e coloração Gram

FIGURA 41 - Colônias obtidas para as amostras: (a) $\mathrm{MMO}_{3}$ e (b) $\mathrm{MMO}_{2}$

FIGURA 42 - Ácidos voláteis quantificados no ensaio cinético - cultura purificada a partir do reator $\mathrm{MMO}$, na presença de nitrato

FIGURA 43 - Separação das bandas em gel de DGGE das amostras do reator MMO e das culturas purificadas $\mathrm{MMO}_{3}(\mathrm{CP} 1)$ e $\mathrm{MMO}_{2}$ (CP2)

FIGURA 44 - Resultado do processo de extração de DNA das amostras de lodo dos reatores anóxicos comparativos, alimentado com etanol, metanol e metano, nas fases B, C e D

FIGURA 45 - Resultado do processo de extração de DNA das amostras de lodo dos reatores anóxicos alimentados com metano, M, MO, MM, MMO e C

FIGURA 46 - Produto da amplificação, por PCR, para o Domínio Bacteria, das amostras de lodo dos reatores RE, RM1 e RM2, nas fases B, C e D

FIGURA 47 - Produto da amplificação, por PCR, para o Domínio Archaea, das amostras de lodo dos reatores RE, RM1 e RM2, nas fases B, C e D

FIGURA 48 - Produto da amplificação, por PCR, para o Domínio Bacteria, das amostras de lodo dos reatores anóxicos alimentado com metano, M, MO, MM, MMO e C

FIGURA 49 - Produto da amplificação, por PCR, para o Domínio Archaea, das amostras de lodo dos reatores anóxicos alimentado com metano, M, MO, MM, MMO e C 


\section{LISTA DE TABELAS}

TABELA 1 - Papel dos metais traço requeridos pelas células 19

TABELA 2 - Descrição e objetivos dos experimentos realizados 22

TABELA 3 - Composição da água residuária sintética que simulou efluente nitrificado 24

TABELA 4 - Composição da solução de sais minerais na água residuária sintética 24

TABELA 5 - Características esperadas para a água residuária sintética 24

TABELA 6 - Concentrações de etanol e metanol para as relações C/N utilizadas 27

TABELA 7 - Esquema das fases em que foram realizados os perfis temporais de 27
concentração de nitrato e nitrito

TABELA 8 - Parâmetros analisados para cada doador de elétrons específico 30

TABELA 9 - Descrição das condições nutricionais dos reatores anóxicos alimentados 32 com metano

TABELA 10 - Composição da solução traço mineral 32

TABELA 11 - Concentração de nitrito utilizada para cada amostra 34

TABELA 12 - Condições nutricionais utilizadas de acordo com a origem do inóculo 34

TABELA 13 - Volume de células purificadas obtidas para cada condição nutricional 36

TABELA 14 - Parâmetros analisados e métodos de análises 39

TABELA 15 - Seqüências dos primers utilizados para amplificação dos fragmentos de 43

TABELA 16 - Composição da reação de PCR 44

TABELA 17 - Temperatura e duração das etapas da amplificação por PCR 44

TABELA 18 - Composição da solução do gel gradiente desnaturante 45

TABELA 19 - Resumo dos resultados obtidos no monitoramento dos reatores 50

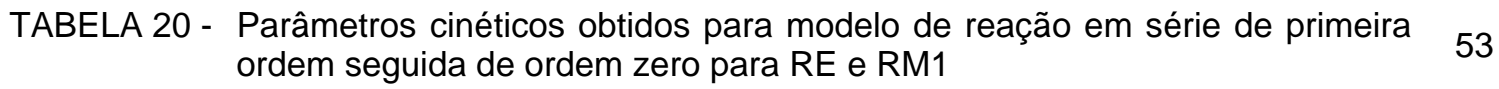

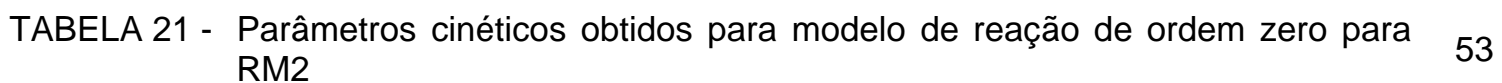

TABELA 22 - Parâmetros cinéticos obtidos para modelo de reação de primeira ordem 55
para consumo de metanol e etanol

TABELA 23 - Alcalinidade teórica produzida durante a desnitrificação 59

TABELA 24 - Alcalinidade a bicarbonato produzida durante o processo de desnitrificação 59

TABELA 25 - Resumo dos resultados provenientes do monitoramento dos reatores 63

TABELA 26 - Parâmetros cinéticos obtidos para os reatores RE e RM1, fase C 67

TABELA 27 - Parâmetros cinéticos obtidos para reator RM2, fase C 67

TABELA 28 - Resumo do monitoramento dos reatores RE e RM1, fase D 70

TABELA 29 - Concentrações máximas de nitrito observadas nos reatores alimentado com 72 metanol e etanol, nas fases B, C e D

TABELA 30 - Parâmetros cinéticos aparentes obtidos para a fase D, nos reatores 73
alimentados com metanol e etanol $\begin{array}{ll}\text { TABELA } 31 \text { - } & \begin{array}{l}\text { Morfologias presentes nas amostras retiradas dos reatores e submetidas à } \\ \text { microscopia de contraste de fase e fluorescência }\end{array} \\ & 75\end{array}$ 
TABELA 32 - Resumo dos resultados obtidos por meio da utilização da técnica de PCR/DGGE

TABELA 33 - Relação F/M calculadas para a fase $B$, dos reatores RM1, RE e RM2

TABELA 34 - Parâmetros cinéticos aparentes para modelo cinético de ordem zero para consumo de nitrato

TABELA 35 - Parâmetros cinéticos para o modelo de reações múltiplas em série obtidos a partir dos dados utilizando metano como doador de elétrons (reator M)

TABELA 36 - Morfologias observadas durante purificação das amostras provenientes dos reatores anóxicos alimentados com metano

TABELA 37 - Morfologias observadas durante purificação das amostras provenientes dos reatores anóxicos alimentados com metano

TABELA 38 - Volume de células purificadas obtidas para cada condição nutricional 


\section{LISTA DE SIGLAS E SÍMBOLOS}

\begin{tabular}{|c|c|}
\hline ATP - & Adenina Tri-fosfato \\
\hline C - & Reator controle \\
\hline C2 - & Amostra purificada na presença de nitrito e ausência de metano \\
\hline C3 - & Amostra purificada na presença de nitrato e ausência de metano \\
\hline $\mathrm{Cf}$ & Lodo floculento - fase C \\
\hline $\mathrm{Cg}$ & Lodo granular - fase C \\
\hline CG & Citosina-Guanina \\
\hline $\mathrm{C} / \mathrm{N}$ & Relação carbono/nitrogênio \\
\hline CONAMA - & Conselho Nacional do Meio Ambiente \\
\hline Df - & Lodo floculento - fase D \\
\hline $\mathrm{Dg}-$ & Lodo granular - fase D \\
\hline DGGE - & Eletroforese em Gel de Gradiente Desnaturante \\
\hline DNA - & Ácido desorribonucléico \\
\hline DQO - & Demanda química de oxigênio \\
\hline EESC - & Escola de Engenharia de São Carlos \\
\hline ERIC - PCR & Enterobacterial Repetitive Intergenic Consensus-PCR \\
\hline FID - & Detector de Ionização de Chama \\
\hline LPB & Laboratório de Processos Biológicos \\
\hline M - & Reator alimentado com metano \\
\hline M2 - & Amostra purificada na presença de metano e nitrito \\
\hline M3 - & Amostra purificada na presença de metano e nitrato \\
\hline MEV - & Microscopia Eletrônica de Varredura \\
\hline MM - & Reator alimentado com metano e metais \\
\hline MM2 - & Amostra purificada na presença de metano, metais e nitrito \\
\hline MM3 - & Amostra purificada na presença de metano, metais e nitrato \\
\hline $\mathrm{MMO}-$ & Reator alimentado com metano, metais e oxigênio \\
\hline MMO2 - & Amostra purificada na presença de metano, metais, oxigênio e nitrito \\
\hline MMO3 - & Amostra purificada na presença de metano, metais, oxigênio e nitrato \\
\hline
\end{tabular}




\begin{tabular}{|c|c|}
\hline $\mathrm{MO}-$ & Reator alimentado com metano e oxigênio \\
\hline MO2 - & Amostra purificada na presença de metano, oxigênio e nitrito \\
\hline MO3 - & Amostra purificada na presença de metano, oxigênio e nitrato \\
\hline N-amon. & Nitrogênio amoniacal \\
\hline NaR - & Enzima nitrato redutase \\
\hline $\mathrm{NiR}-$ & Enzima nitrito redutase \\
\hline NMP - & Número Mais Provável \\
\hline NOR - & Enzima redutase do óxido nítrico \\
\hline $\mathrm{N}_{2} \mathrm{OR}-$ & Enzima redutase do óxido nitroso \\
\hline PCR - & Reação de Polimerização em Cadeia \\
\hline RANA - & Redução Assimilativa de Nitrato à Amônia \\
\hline RDNA - & Redução Dissimilativa de Nitrato à Amônia \\
\hline RE - & Reator alimentado com etanol \\
\hline RM1 - & Reator alimentado com metanol \\
\hline RM2 - & Reator alimentado com metano \\
\hline RNA - & Ácido ribonucléico \\
\hline ST - & Sólidos Totais \\
\hline STF - & Sólidos Totais Fixos \\
\hline STV - & Sólidos Totais Voláteis \\
\hline UNICAMP - & Universidade Estadual de Campinas \\
\hline USF & Universidade de São Paulo \\
\hline
\end{tabular}




\section{SUMÁRIO}

RESUMO

ABSTRACT

1. INTRODUÇÃO

2. OBJETIVOGERAL

3. OBJETIVOS ESPECÍFICOS

4. REVISÃO DA LITERATURA

4.1 Desnitrificação

4.2 Metano como doador de elétrons 12

$\begin{array}{ll}4.3 \text { Cinética da desnitrificação } & 15\end{array}$

4.4 Redução Dissimilativa de Nitrato à Amônia 17

4.5 Suplementação de sistemas desnitrificantes com micronutrientes 18

4.6 Diversidade microbiana - utilização de técnicas moleculares 20

5. METODOLOGIA

5.1. Inóculo 23

5.2 Água residuária sintética $\quad 24$

5.3. Experimentos com reatores anóxicos comparativos 24

$\begin{array}{ll}5.4 \text { Experimentos com reatores para estudo cinético } & 28\end{array}$

5.5 Experimentos com reatores anóxicos alimentados com metano 30

5.6 Ensaio de purificação 33

5.6.1. Crescimento das culturas em meio sólido 36

5.6.2. Ensaio para obtenção da cinética de crescimento celular 37

5.7 Parâmetros e métodos de análises 38

5.7.1. Metodologias utilizadas nas análises de Biologia Molecular 41

5.7.1.1. Extração de DNA $\quad 41$

5.7.1.2. Amplificação por PCR 43

5.7.1.3 Eletroforese em gel de gradiente desnaturante (DGGE) 45

5.8 Análise dos resultados obtidos nos ensaios cinéticos 46

6. RESULTADOS E DISCUSSÃO

6.1. Experimentos com reatores anóxicos comparativos 47

6.1.1 Relação $\mathrm{C} / \mathrm{N}=1,5 \quad 47$

6.1.2. Relação $\mathrm{C} / \mathrm{N}=1$ (Fases A e B) 47

6.1.3. Relação $\mathrm{C} / \mathrm{N}=0,75$ (Fase $\mathrm{C}$ ) 60

6.1.4. Relação $\mathrm{C} / \mathrm{N}=0,5$ (Fase $\mathrm{D}$ ) 69

6.1.5. Acompanhamento morfológico do lodo $\quad 74$

6.1.6. Análise da diversidade microbiana $\quad 79$

6.2. Experimentos com reatores para estudo cinético 90

6.3 Experimentos com reatores anóxicos alimentados com metano 94

$\begin{array}{ll}\text { 6.4. Ensaio de Purificação } & 104\end{array}$

6.5. Crescimento das culturas em meio sólido 108

6.6. Ensaio para obtenção da cinética de crescimento celular 108

7. CONCLUSÕES 112

\begin{tabular}{lr} 
8. SUGESTÕES & 118 \\
\hline & 120
\end{tabular}

9. REFERÊNCIAS BIBLIOGRÁFICAS

$\begin{array}{ll}\text { 10. APÊNDICES } & 127\end{array}$

10.1. Apêndice 1 - Resultados de Extração de DNA 127

10.2. Apêndice 2 - Produtos de PCR 129 


\section{RESUMO}

SANTOS, S. G. (2003). Utilização de metanol, etanol e metano como doadores de elétrons para a desnitrificação. Tese (Doutorado) - Escola de Engenharia de São Carlos, Universidade de São Paulo, São Carlos, 2003.

Esta tese apresenta e discute os dados obtidos a partir de trabalho experimental projetado para avaliar comparativamente o desempenho de reatores desnitrificantes em batelada, tendo etanol, metanol e gás metano como doadores de elétrons. Os experimentos foram realizados em reatores em escala de bancada. Os ensaios com gás metano objetivaram verificar a efetividade deste sub-produto de reatores anaeróbios em substituir os doadores exógenos de elétrons comumente utilizados, tais como metanol e etanol. Para alcançar o objetivo principal deste trabalho, os parâmetros cinéticos de desnitrificação, para os doadores de elétrons ensaiados, foram determinados nas diferentes condições operacionais. Além disso, as alterações ocorridas na população microbiana, ao longo do período experimental, foram avaliadas em relação à diversidade microbiana, por meio de análises microscópicas (óptica, de fluorescência e eletrônica de varredura) e da técnica de Biologia Molecular de PCR/DGGE. A completa desnitrificação foi alcançada para todos os compostos testados, e o etanol foi o doador de elétrons mais eficiente para a desnitrificação. A melhor razão carbono-nitrogênio para a desnitrificação foi igual a 1,0. Contudo, este parâmetro foi encontrado ser inadequado para utilização no processo de desnitrificação, uma vez que não expressa a capacidade real do composto usado em doar elétrons. A desnitrificação com metano ocorreu tanto na presença como na ausência de oxigênio, embora a baixas velocidades quando comparado com os outros compostos. No entanto, a configuração do reator utilizado neste estudo não foi adequada para promover a efetiva dissolução do gás metano na fase líquida. Por essa razão, sugere-se o desenvolvimento de configurações de reatores apropriadas para minimizar as resistências à transferência de massa da fase gasosa para a líquida e também desta para a biomassa.

Palavras Chave: desnitrificação, etanol, metanol, metano, cinética, diversidade microbiana. 


\section{ABSTRACT}

SANTOS, S. G. (2003). The use of methanol, ethanol and methane as electrons donors for denitrification. Ph.D Thesis - Escola de Engenharia de São Carlos, Universidade de São Paulo, São Carlos, 2003.

This thesis presents and discusses the data obtained from an experimental work designed to evaluate the comparative performance of denitrifying batch reactors utilizing ethanol, methanol and methane gas as electron donors. The experiments were carried out at using bench-scale reactors. The experiments using methane gas were meant to verify the effectiveness of such a by-product of anaerobic reactors instead of exogenous electron donors commonly used, such as methanol and ethanol. To achieve this main objective, the kinetic parameters of denitrification for the distinct electron donors assayed were determined in different operating conditions. Besides, the microbial population changes inside the reactors along the experimental time were evaluated in respect to the microbial diversity, by means of microscopy analysis (optical, fluorescent and electronic scanning) and the Molecular Biology technique, PCR/DGGE. Complete denitrification was achieved with all the compounds tested, and ethanol was the most effective electron donor for denitrification. The best carbon to nitrogen ratio for denitrification was 1.0. However, this parameter was found to be inadequate for using in denitrification process, since it does not express the real capacity of the compound used to donate electrons. Denitrification with methane occurred in the presence and also in the absence of oxygen, although at lower velocities compared to those with the other compounds. However, the reactor configuration utilized in this study was not adequate to promote the effective methane gas dissolution in the liquid phase. Therefore, it is suggested the development of appropriate reactor configurations to minimize mass transfer resistances from the gas to the liquid phase and also from that to the biomass.

Keywords: denitrification, ethanol, methanol, methane, kinetic, microbial diversity. 


\section{INTRODUÇÃO}

A qualidade da água, de grande parte dos rios brasileiros, encontra-se comprometida devido, principalmente, ao lançamento de efluentes domésticos e industriais, na maioria da vezes, sem ter sido submetido a nenhum tipo de tratamento.

O lançamento direto de esgotos domésticos e de efluentes de sistemas de tratamentos de esgotos, contribui para o aumento da quantidade de nutrientes nos corpos d’água, principalmente nitrogênio e fósforo, que em concentrações elevadas, podem provocar a proliferação excessiva de algas e, como conseqüência, tornar os corpos d’água eutrofizados. A eutrofização dos corpos d'água provoca o desequilíbrio ecológico entre as diversas formas de vida presente nos rios e lagos, provocando impacto ambiental considerável e deteriorando a qualidade da água, motivo pelo qual deve ser evitada. Além disso, a presença de nitrogênio, nas formas de nitrato e nitrito, também é alvo de grande preocupação, pois o nitrito é potencialmente cancerígeno (formação de nitrossaminas) e causador de deficiência de hemoglobina no sangue, em crianças. Rajapakse e Scutt (1999) afirmam que os riscos à saúde, decorrentes da presença de nitrato e nitrito, em água utilizada para consumo humano, vão desde hipertrofia de tireóide a 15 diferentes tipos de câncer, incluindo defeitos de nascimento e hipertensão em adultos.

Devido a esses fatores, a legislação tem sido cada vez mais restritiva quanto ao lançamento de efluentes que contenham nitrato e nitrito. No Brasil, a resolução CONAMA 20/86 não estabelece diretamente as concentrações de nitrato e nitrito que podem estar presentes nos efluentes de sistemas de tratamento de esgotos. Apenas a concentração de amônia encontra-se limitada em 5 mg-N/L. No entanto, a limitação das concentrações de nitrato e nitrito acaba sendo indireta, pois o artigo 23 dessa resolução determina que: “Os efluentes não poderão conferir ao corpo receptor características em desacordo com o seu enquadramento”. De acordo com a classificação das águas doces, pertencentes às classes 1, 2 e 3, do Território Nacional, as concentrações máximas admitidas, de nitrato e nitrito, são iguais a $10 \mathrm{mg} \mathrm{N}-\mathrm{NO}_{3}{ }^{-} / \mathrm{L}$ e $1,0 \mathrm{mg} \mathrm{N}-\mathrm{NO}_{2}{ }^{-} / \mathrm{L}$, 
respectivamente. Desta forma, de acordo com a classe do rio no qual se deseja efetuar o lançamento, a somatória das cargas dos efluentes não pode ultrapassar a capacidade suporte do corpo d’água.

Outros países limitam as concentrações para lançamento de nitrato em níveis bem mais restritivos do que o Brasil. Por exemplo, atualmente exige-se que algumas indústrias da comunidade européia introduzam o processo de desnitrificação nos seus sistemas de tratamento de águas residuárias (RAJAPAKSE e SCUTT, 1999); nos países da América do Norte a descarga de efluentes que contenham nitrato está limitada em 5 mg $\mathrm{N}^{-\mathrm{NO}_{3}}{ }^{-} / \mathrm{L}$, enquanto que a legislação do Canadá reduziu esse limite para 2mg N$\mathrm{NO}_{3}{ }^{-} / \mathrm{L}$ (LOUZEIRO et al., 2002).

Por esse motivo, além de remover matéria orgânica, as estações de tratamento de esgotos estão cada vez mais se adaptando para promover a remoção de nutrientes, principalmente nitrogênio e fósforo. Dessa forma, é fundamental a realização de pesquisas que buscam o desenvolvimento de tecnologias visando a minimização dos custos e maximização da eficiência de remoção de poluentes. Nesse contexto, destacamse os sistemas de tratamento biológico utilizados para controlar a quantidade de nutrientes presente nos efluentes de sistemas de tratamento de águas residuárias.

Sistemas de tratamento para remoção de nitrogênio de águas residuárias, incluindo os processos de nitrificação/desnitrificação, têm sido empregados com sucesso. É importante que o processo de desnitrificação seja atingido, pois é através dele que o nitrogênio é liberado para a atmosfera, na forma gasosa. Como os efluentes de tratamentos secundários apresentam baixas concentrações de carbono orgânico residual, fontes externas são usualmente utilizadas para promover o processo de desnitrificação biológica.

A larga experiência adquirida pelo grupo de pesquisa em Biotecnologia anaeróbia do Laboratório de Processos Biológicos - LPB, do Departamento de Hidráulica e Saneamento da Escola de Engenharia de São Carlos - USP, comprova a grande viabilidade de remoção de nutrientes através da combinação dos processos anaeróbio e aeróbio. Pesquisas mais recentes (VIEIRA, 2000; CALLADO, 2001) apontam para a necessidade de se estudarem os diferentes doadores de elétrons que podem ser utilizados para a desnitrificação. O principal objetivo dessa linha de pesquisa é verificar a viabilidade do uso de fontes internas de doadores de elétrons no sentido de minimizar os custos decorrentes da adição de fontes exógenas de carbono e tornar mais acessível a aplicação de técnicas de remoção de nutrientes. 
O trabalho de Callado (2001) indicou que o gás metano, produzido durante o processo de digestão anaeróbia, apresenta potencial para ser aproveitado como fonte interna de elétrons para a desnitrificação. Apesar de alguns resultados promissores já terem sido alcançados, as vias metabólicas envolvidas são ainda desconhecidas, havendo controvérsia sobre várias etapas do processo.

Para dar continuidade às pesquisas sobre pós-tratamento de esgotos, este trabalho pretendeu contribuir para o aprofundamento no conhecimento do processo de desnitrificação biológica, através da investigação comparativa sobre a eficiência do processo, quando promovido na presença dos doadores de elétrons, metanol, etanol e metano.

O metanol é o composto mais utilizado como fonte externa de carbono para a desnitrificação nos países do hemisfério norte. No Brasil, o etanol é produzido em grande escala a partir da cana de açúcar e apresenta custo inferior ao metanol. Enquanto o gás metano é produzido durante o processo de digestão anaeróbia, processo este que se encontra completamente estabelecido como tecnologia para remoção de matéria orgânica, sendo representativo de fonte interna de elétrons para a desnitrificação.

Neste trabalho, esses três doadores de elétrons foram utilizados com o objetivo de se comparar o desempenho do processo de desnitrificação em relação ao doador de elétrons. Além disso, a influencia da relação $\mathrm{C} / \mathrm{N}$ foi também avaliada nos reatores suplementados com metanol e etanol. 


\section{OBJETIVO GERAL}

Verificar a eficiência da desnitrificação utilizando metanol, etanol e metano como doadores de elétrons.

\section{OBJETIVOS ESPECÍFICOS}

$\diamond$ Obter parâmetros cinéticos de desnitrificação para os doadores de elétrons: metanol, etanol e metano.

$\diamond \quad$ Avaliar a diversidade microbiana presente nos reatores desnitrificantes por meio da técnica de PCR/DGGE (reação de polimerase em cadeia/eletroforese em gel de gradiente desnaturante);

$\diamond$ Acompanhar a dinâmica das morfologias presentes nos reatores, ao longo do tempo de operação, por meio de técnicas microscópicas.

$\diamond$ Verificar a viabilidade de utilização do gás metano como doador de elétrons para a desnitrificação. 


\section{REVISÃO DA LITERATURA}

Efluentes de reatores anaeróbios utilizados para tratamento de esgotos, em geral, não atendem aos padrões de emissão estabelecidos pela legislação brasileira, devido à presença de microrganismos patogênicos, da fração remanescente de matéria orgânica solúvel e particulada, e de nutrientes, principalmente nitrogênio e fósforo.

Sistemas de tratamento para remoção de nitrogênio de águas residuárias, que incluem os processos de nitrificação e desnitrificação, têm sido bastante utilizados. A nitrificação consiste em um processo biológico, através do qual ocorre a oxidação do íon amônio $\left(\mathrm{NH}_{4}{ }^{+}\right)$ao íon nitrato $\left(\mathrm{NO}_{3}^{-}\right)$, em ambientes aeróbios.

Pelo fato de as bactérias nitrificantes apresentarem baixa velocidade de crescimento e serem mais sensíveis, do que os microrganismos desnitrificantes, à cargas tóxicas e mudanças das condições ambientais, como $\mathrm{pH}$ e temperatura, sobre elas vem se concentrando a maior parte dos estudos que envolvem a remoção de nitrogênio. As bactérias quimiolitoautotróficas conhecidas por serem as mais importantes para nitrificação são as pertencentes aos gêneros Nitrossomonas e Nitrobacter. No entanto, recentemente, as técnicas de Biologia Molecular permitiram observar que as espécies Nitrosococcus mobilis e Nitrospira sp têm representado as populações dominantes em sistemas de lodos ativados de tratamento de águas residuárias domésticas e industriais (DABERT et al., 2002).

O processo de nitrificação, isoladamente, não alivia o problema da eutrofização, pois o nitrato é um nutriente prontamente utilizável por vegetais, podendo provocar a proliferação de algas nos corpos d'água receptores.

Para que a remoção de nitrogênio realmente minimize os problemas decorrentes do lançamento desse composto no meio ambiente é necessário que o processo de desnitrificação seja realizado.

A seguir são fornecidas algumas definições que se fazem necessárias para que o processo de desnitrificação biológica seja mais bem compreendido. 


\subsection{Desnitrificação}

A desnitrificação é a conversão biológica do nitrogênio, na forma de nitrato, a formas mais reduzidas, como $\mathrm{NO}, \mathrm{N}_{2} \mathrm{O}$ e $\mathrm{N}_{2}$ (ROS, 1995). Esse processo ocorre através da ação de bactérias anaeróbias facultativas heterótrofas, que utilizam matéria orgânica como fonte de carbono e de energia. As rotas bioquímicas utilizadas são idênticas àquelas envolvidas na respiração, exceto pelo aceptor de elétrons que, na desnitrificação, é o nitrato.

De acordo com Tiedje (1988), o termo redução aplica-se a redução de nitrato para nitrito apenas. Já o termo desnitrificação é utilizado para redução de um dos óxidos de nitrogênio (nitrato ou nitrito) para um dos compostos gasosos de nitrogênio, oxido nítrico, nitroso ou $\mathrm{N}_{2}$. No entanto, a desnitrificação é considerada completa quando o produto $\mathrm{N}_{2}$ é formado.

Na Figura 1 são ilustrados os complexos de transferência de elétrons e produção de energia associada com a respiração anóxica. A seguir, é realizada uma discussão sobre a Figura 1, baseada nos textos apresentados por Averill e Tiedje (1982); Casey et al. (1999a); Casey et al. (1999b); Madigan et al. (1997) e Leningher (1975).

Durante a transferência de elétrons do NADH para as enzimas redutases dos óxidos de nitrogênio (nitrato redutase e nitrito redutase), os elétrons passam apenas por dois estágios de conservação de energia (estágios 1 e 2 - Figura 1), enquanto que, na respiração aeróbia, eles passam por três estágios, tendo o citocromo $a$ participação no processo aeróbio. Os compostos NADH desidrogenase, ubiquinona (Q), citocromo bc e citocromo $c$ são comuns aos sistemas de transporte de elétrons aeróbio e anóxico.

A enzima nitrato redutase $(\mathrm{NaR})$ é considerada ser a mais importante da respiração anóxica. Sua ação consiste na redução de nitrato a nitrito, que ocorre na membrana celular (Figura 1). Os elétrons passam da ubiquinona (Q) para a enzima NaR. Na catálise da enzima $\mathrm{NaR}$, dois elétrons são passados para o nitrato, processo este que resulta no deslocamento de dois prótons, a partir do periplasma, para formar nitrito e água.

Durante a transferência de dois elétrons para a enzima NaR, a ubiquinona (Q) ejeta dois prótons para o periplasma, no processo de transferência de elétrons para o complexo $b c_{t}$, e estabelece a posição para a redução do nitrato, sendo este o segundo estágio de conservação de energia do caminho da respiração anóxica. 


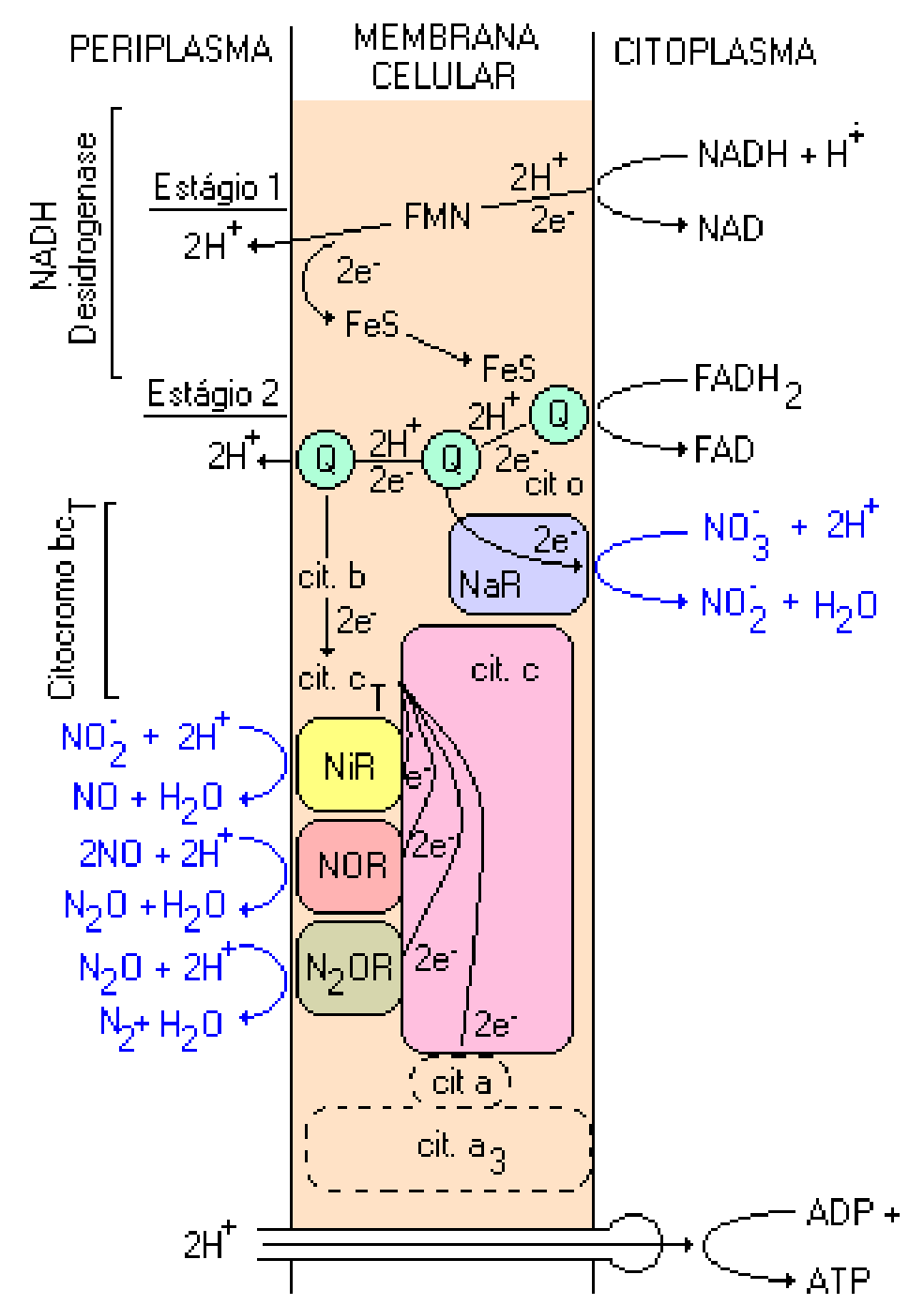

Figura 1. Sistema de transporte de elétrons envolvido na desnitrificação. Fonte: Casey et al. (1999a), modificado de acordo com Black (2002).

Definido o local, no citoplasma, do sítio ativo da enzima NaR, o nitrato tem que ser transportado através da membrana celular (ou citoplasmática), do espaço periplasmático para o citoplasma, para ser reduzido. O primeiro processo refere-se ao estabelecimento da ligação $\mathrm{H}^{+}-\mathrm{NO}_{3}^{-}$, mecanismo este dependente da força motriz estabelecida pela movimentação de prótons através da membrana celular. O nitrato atravessa a membrana, juntamente com dois ou mais prótons, durante a produção de ATP, e é reduzido para nitrito na membrana celular. Para cada molécula de nitrato que atravessa a membrana celular, uma molécula de nitrito pode retornar ao espaço periplasmático.

Em seguida, entra em ação a enzima nitrito redutase (NiR), cuja função é reduzir nitrito, presente no meio líquido ou originado da redução de nitrato, para óxido nítrico. 
A enzima nitrito redutase, situada no espaço periplasmático da membrana celular, recebe um elétron do citocromo $c$ e, do sítio catalítico da redutase, o elétron é transferido para o nitrito, em processo que transporta, também, dois prótons do periplasma, para formar óxido nítrico e água. Para cada par de elétrons que passa para o nitrito, quatro prótons são bombeados através da membrana, de forma que o microrganismo tem o mesmo ganho energético, tanto para reduzir nitrato, como nitrito.

Dois diferentes tipos de enzima nitrito redutase têm sido identificados: um citocromo complexo contendo sítios do tipo $c$ e tipo-d, referido como $c d_{t}$ e um citocromo complexo contendo cobre. Aparentemente, ambos desempenham a mesma função, mas estão presentes em diferentes espécies de organismos desnitrificantes (SHAPLEIGH e PAYNE, 1985).

A produção de NO por desnitrificantes é questionada na literatura, porque, embora $\mathrm{N}_{2} \mathrm{O}$ seja usualmente detectado, o mesmo não ocorre com NO (AVERILL e TIEDJE, 1982). Alguns autores acreditam que o NO não é detectado porque está presente, apenas, no interior das células e em concentrações muito baixas (CARR e FERGUSON, 1990). Contudo, sob condições adversas como, por exemplo, concentração elevada de nitrito, presença de toxinas ou em células velhas, este pode excretado para fora da célula (CASEY et al., 1999b).

A função da enzima redutase do óxido nítrico (NOR) é reduzir o óxido nítrico para óxido nitroso. Existe incerteza considerável sobre a posição desta enzima, em relação à membrana celular. O que distingue esta redutase das outras, é que ela é responsável pela formação da ligação $\mathrm{N}-\mathrm{N}$ do $\mathrm{N}_{2} \mathrm{O}$. Para isto, duas moléculas de NO são requeridas para formação de uma molécula de $\mathrm{N}_{2} \mathrm{O}$. Esta redutase recebe um par de elétrons do citocromo $c$. Do sítio catalítico da redutase, os elétrons passam para duas moléculas de óxido nítrico, processo este que transporta dois prótons para formar cada molécula de óxido nitroso e água. Para cada par de elétrons originados do NADH, recebidos pelo óxido nítrico, quatro prótons são bombeados através da membrana, apresentando a mesma proporção entre prótons e elétrons da redução de nitrato e nitrito. Por este motivo, a produção energética é similar nesses processos de redução.

Finalmente, a função da enzima redutase do óxido nitroso $\left(\mathrm{N}_{2} \mathrm{OR}\right)$ é reduzir óxido nitroso a $\mathrm{N}_{2}$. Esta enzima está situada no espaço periplasmático da membrana celular e recebe um par de elétrons do citocromo $c$ e, do sítio catalítico da enzima, os elétrons são transferidos para o óxido nitroso, processo que transporta, também, dois prótons do periplasma. O produto final é liberado da célula. O par de elétrons é 
transferido pelos mesmos complexos já citados nos processos de redução anteriormente descritos.

Nem todos os microrganismos, classificados como desnitrificantes, podem executar toda a rota metabólica, desde nitrato até $\mathrm{N}_{2}$. Alguns microrganismos são capazes de executar apenas uma parte desse metabolismo, a partir de um dos compostos iônicos de nitrogênio (nitrato ou nitrito) para um dos compostos gasosos ( $\mathrm{NO}, \mathrm{N}_{2} \mathrm{O}$ ou $\mathrm{N}_{2}$ ) e estes organismos são identificados como desnitrificantes parciais. Além disso, alguns organismos são capazes, apenas, de reduzir nitrato para nitrito, sendo referidos como redutores de nitrato (CASEY et al., 1999a; BOTHE et al., 2000).

A desnitrificação pode ocorrer devido à atividade de diversas espécies de bactérias desnitrificantes ou desnitrificantes parciais, comumente encontradas nos sistemas biológicos de tratamento de esgotos, como: Pseudomonas, Alcaligenes, Flavobacterium, Achromobacter, Bacillus, Micrococcus, Acinetobacter, dentre outras. Essas culturas apresentam desenvolvimento relativamente fácil nos reatores biológicos.(TIEDJE, 1988; EISENTRAEGER et. al., 2001)

Utilizando sondas genéticas (análise DNAr 16S), Etchebehere et al. (2000) identificaram as seguintes culturas de bactérias desnitrificantes: Thauera aromatica, Alcaligenes defragrans, Comamonas terrigena e Acidovorax sp. LW1.

Segundo Madigan et al. (1997), os passos da redução dissimilativa, a formas intermediárias gasosas de nitrogênio, são mostrados a seguir:

$$
\mathrm{N}^{-\mathrm{NO}_{3}}{ }^{-} \rightarrow{\mathrm{N}-\mathrm{NO}_{2}}^{-} \rightarrow \mathrm{N}-\mathrm{NO} \rightarrow \mathrm{N}-\mathrm{N}_{2} \mathrm{O} \rightarrow \mathrm{N}^{-\mathrm{N}_{2}}
$$

As bactérias responsáveis pela desnitrificação utilizam matéria orgânica como fonte de carbono e de energia. Porém, efluentes de tratamentos secundários apresentam baixas concentrações de carbono orgânico residual. Por esse motivo, fontes externas de carbono são usualmente utilizadas para promover o processo de desnitrificação (BENEFIELD e RANDALL, 1980).

Metanol e etanol têm sido muito utilizados como fontes de carbono, pois suas eficiências na desnitrificação foram comprovadas (HER e HUANG, 1995; ZHAO et al., 1999). Outras fontes, como glicose (HER e HUANG, 1995), etanol (NYBERG et al., 1996) e acetato (BANDPI et al., 1999), também têm sido utilizadas. Entretanto, o uso desses compostos pode inviabilizar aplicações em grande escala, pelo alto custo (COSTA et al., 2000). 
Pochana e Keller (1999) realizaram experimentos utilizando acetato com fonte de carbono. A adição de acetato foi realizada em períodos alternados, de aproximadamente 10 dias. No primeiro período, na ausência de acetato, a concentração de nitrato no efluente foi muito alto. No $11^{\circ}$ dia, após a adição de acetato, ocorreu, com certa defasagem, decréscimo drástico da concentração de nitrato. Da mesma forma, quando cessou adição de acetato, no $20^{\circ}$ dia, foi observado novo acúmulo de nitrato. Esse experimento confirmou que a introdução de uma fonte externa de carbono é criticamente importante para que a desnitrificação total de águas residuárias seja atingida.

Houbron et al. (1999) sugerem que o metano pode ser fonte externa alternativa de carbono, por ser um composto natural, barato, não tóxico e apresentar facilidade de eliminação.

Her e Huang (1995) utilizaram metanol, ácido acético e glicose como fontes de carbono e verificaram que diferentes funções orgânicas e relações carbono/nitrogênio $(\mathrm{C} / \mathrm{N})$ inadequadas provocaram acúmulos de compostos intermediários. Quando quantidades insuficientes das fontes de carbono foram utilizadas na desnitrificação, ocorreu acúmulo de nitrito.

Segundo Houbron et al. (1999), a relação de massas C/N, para a desnitrificação, deve ser de aproximadamente 3. Na maior parte dos estudos realizados, essa relação esteve entre 6 e 7 (POCHANA e KELLER, 1999, SHIEH e MULCAHY, 1986). Contudo, Callado (2001) apresentou, em uma relação dos valores de razões C/N encontradas na literatura, a faixa entre 0,9 a 1,7, como sendo os valores ótimos para promover de forma adequada o processo de desnitrificação.

Chiu et al. (2003) concluíram que a relação C/N para a desnitrificação deve variar de acordo com a concentração de nitrato presente no meio líquido, sendo que quanto maior a concentração de nitrato, menor foi o valor da relação $\mathrm{C} / \mathrm{N}$. Os valores recomendados foram iguais a 5,5; 4,5; 4,0 e 2,6, para as concentrações de $\mathrm{N}_{-}-\mathrm{NO}_{3}{ }^{-}$de 25 , 50, 100 e $200 \mathrm{mg} / \mathrm{L}$, respectivamente. Nos experimentos os autores utilizaram acetato de sódio como fonte exógena de carbono.

Baixos valores da relação $\mathrm{C} / \mathrm{N}$ podem causar acúmulo de nitrito nos reatores biológicos (BANDPI e ELLIOTT, 1998), enquanto a redução dissimilativa de nitrato a amônia pode ocorrer, para elevadas relações C/N (GYLSBERG et al. 1998), prejudicando o processo de desnitrificação. 
Os principais fatores que interferem na desnitrificação são $\mathrm{pH}$, temperatura e concentração de OD. A manutenção de baixas concentrações de oxigênio dissolvido nos sistemas desnitrificantes é fator essencial para que bons níveis de redução de nitrato sejam alcançados. A desnitrificação pode ser melhor na ausência de OD. Segundo Pochana e Keller (1999), a eficiência da desnitrificação decresce quando a concentração de OD é superior a $0,2 \mathrm{mgO}_{2} / \mathrm{L}$.

A temperatura e o pH são as condições ambientais mais importantes para o desenvolvimento da desnitrificação. Para Van Haandel e Marais (1999), a desnitrificação pode se desenvolver na faixa de temperatura de $7^{\circ} \mathrm{C}$ a $40^{\circ} \mathrm{C}$ e, abaixo de $3^{\circ} \mathrm{C}$, nenhuma desnitrificação é observada. Entretanto, na maioria dos estudos de desnitrificação desenvolvidos, a temperatura é mantida na faixa de $20^{\circ} \mathrm{C}$ a $30^{\circ} \mathrm{C}$.

Vários autores afirmam que a faixa ótima de $\mathrm{pH}$, para a desnitrificação, situa-se entre 6,5 e 7,5, e que, em $\mathrm{pH}<6,0$ e $\mathrm{pH}>8,0$, ocorrem diminuições nas atividades de bactérias desnitrificantes.

Considerando os parâmetros $\mathrm{pH}$, temperatura, tempo de detenção hidráulico (TDH) e relação $\mathrm{C} / \mathrm{N}$ como sendo os mais importantes para o estabelecimento de população desnitrificante em reatores anóxicos, Jianping et al. (2003) variaram esses parâmetros, tendo encontrado, como valores ótimos, o $\mathrm{pH}$ de 7,5, a temperatura de $30^{\circ} \mathrm{C}$, TDH igual a 2,5h e a relação $\mathrm{C} / \mathrm{N}$ igual a 0,95 . Nessas condições, os autores operaram biorreator contínuo de três fases contendo biomassa imobilizada em carvão ativado, sendo o metanol utilizado como fonte exógena de carbono adicionado a efluente nitrificado sintético, de indústria de fertilizante, a fim de desnitrificar 460 mgN/L de nitrato. As eficiências de remoção de nitrato e DQO, alcançadas para as condições ótimas, foram iguais a 96\% e 93\%, respectivamente. No caso dessa indústria, o metanol constituiu fonte exógena de baixo custo por ser sub-produto do processo de produção de carbamida.

Além desses fatores, é preciso conhecer as causas da redução direta de nitrato a amônia e da acumulação de nitrito nos processos de desnitrificação. Callado (2001) afirma que o acúmulo indesejado de nitrito, em sistemas de nitrificação e desnitrificação, tem ocorrido devido às dificuldades no estabelecimento de parâmetros operacionais ideais e na compreensão das interações que ocorrem entre os fatores reguladores do processo, enfocando a necessidade de estudos sobre as influências do tipo de fonte de carbono e da relação C/N no acúmulo de nitrito. 


\subsection{Metano como doador de elétrons}

De acordo com Jeris e McCarty.(1964), o metano representa de 60 a 80\% do biogás produzido nos sistemas de tratamento anaeróbios de esgotos domésticos. Por esse motivo, o seu aproveitamento para a desnitrificação representa uma alternativa bastante interessante, necessitando de estudos que comprovem a sua viabilidade.

Estudos sobre a utilização de metano como único doador de elétrons para a desnitrificação são escassos. Eisentraeger et al. (2001) comentam sobre o insucesso de um sistema piloto construído na Alemanha, para remediação de águas subterrâneas contaminadas com nitrato, através da introdução de gás metano. Segundo os autores, esse insucesso foi decorrente da falta de conhecimento sobre os fundamentos do consumo microbiano de metano.

Segundo Madigan et al. (1997), as bactérias metanotróficas utilizam metano como doador de elétrons para obtenção de energia e como única fonte de carbono. Esses microrganismos possuem um sistema enzimático específico, denominado metano monoxigenase, responsável pela introdução de um átomo de oxigênio na molécula de metano, levando à formação de metanol e, por isto, estas bactérias são aeróbias obrigatórias. Os autores consideram interessante o mecanismo bioquímico da oxidação do metano, que envolve, em cada passo, a oxidação por um par de elétrons:

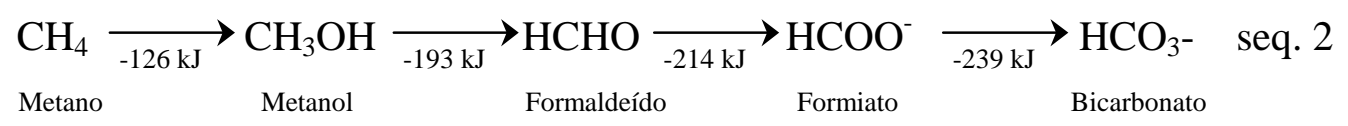

Svenning et al. (2003) purificaram culturas de bactérias metanotróficas, a partir de amostras de solo, em meio padrão contendo nitrato. A técnica de diluições decimais seriadas (NMP) foi aplicada ao sistema de membrana solo substrato para obtenção das culturas purificadas. Os autores observaram que as culturas isoladas, após purificação, eram constituídas por bacilos curvos e retos e cocos. A análise da diversidade das bactérias metanotróficas purificadas, através da utilização da técnica de fingerprinting ERIC-PCR (Enterobacterial Repetitive Intergenic Consensus-PCR), utilizando primers específicos para amplificação de genes funcionais dos grupos de bactérias metanotróficas I e II, permitiu detectar que haviam até 10 linhagens diferentes na mesma amostra purificada. 
As bactérias metanotróficas também podem nitrificar e oxidar amônia para nitrito. De acordo com Bothe et al. (2000), metanotróficas e bactérias oxidadoras de amônia ocupam nichos similares em solos e em habitat aquáticos, que contenham gradientes de oxigênio e metano ou amônia, respectivamente. Suas interações são complexas e pouco conhecidas até agora.

Em amostras de solo, Horz et al. (2002) detectaram, através da técnica de DGGE, a presença de bactérias metanotróficas nos primeiros $20 \mathrm{~cm}$ de profundidade de solo fertilizado com 50-80 kg N/ha.ano, utilizado para pasto de cavalos. Os autores monitoraram a concentração de $\mathrm{CH}_{4}$ e de $\mathrm{O}_{2}$ e afirmam que, nos primeiros $5 \mathrm{~cm}$ de solo, foi utilizado o $\mathrm{CH}_{4}$ da atmosfera, sendo que as populações de metanotróficas, encontradas abaixo de $5 \mathrm{~cm}$, utilizaram o metano produzido por micro-sítios anaeróbios.

Existe grande interesse em compreender melhor as características funcionais e fisiológicas dessas bactérias uma vez que, de acordo com Svenning et al. (2003), esses microrganismos apresentam grande potencial para utilização em biorremediação por serem capazes de co-oxidar uma grande variedade de hidrocarbonetos halogenados. Além disso, é muito provável que bactérias metanotróficas sejam comuns ocorrer em ambientes que contenham metano, sendo necessário apenas, haver oxigênio em concentrações microaerofílicas.

Para a ocorrência do processo de desnitrificação, tendo metano como doador de elétrons, quando a concentração de oxigênio é baixa, duas hipóteses principais têm sido aventadas: i) a desnitrificação ocorre pela ação de bactérias consumidoras de metano e capazes de utilizar nitrato como aceptor de elétrons na presença de oxigênio e; ii) inicialmente ocorre a produção de um intermediário orgânico, pela ação de uma associação de bactérias metanotróficas, sendo este composto utilizado, a seguir, como fonte de carbono para as bactérias desnitrificantes aeróbias, anaeróbias ou facultativas. A primeira hipótese não está demonstrada até o momento, enquanto a segunda tem sido claramente comprovada por vários autores (THALASSO et al., 1997; COSTA et al., 2000). Adicionalmente, a ocorrência da desnitrificação na presença de metano como única fonte de carbono, sob condições anóxicas (ausência de oxigênio), foi demonstrada recentemente (ISLAS-LIMA et al., 2002).

Costa et al. (2000) realizaram experimentos em batelada sob condições microaerófilas e sugerem que a desnitrificação, através de metano, ocorre pela ação de um consórcio constituído por dois tipos de bactérias: as metanotróficas (capazes de oxidar metano e produzir um composto orgânico) e as desnitrificantes (que utilizam 
esses compostos como doadores de elétrons para a desnitrificação). Os autores propõem, nos seus experimentos, que o acetato foi o composto produzido pelas metanotróficas durante crescimento, sob concentração limitada de oxigênio. No entanto, segundo esses autores, apesar de a desnitrificação com metano sob condições limitantes de oxigênio ter sido demonstrada, os mecanismos desse processo e os microrganismos envolvidos são ainda desconhecidos.

A partir dos resultados obtidos em seus experimentos, Thalasso et al. (1997) questionam a viabilidade da desnitrificação com metano, pois foi observado que, quanto maior a pressão parcial de oxigênio, melhor foi a eficiência da desnitrificação, mas também foi maior o crescimento da biomassa. Foi confirmado o crescimento de bactérias desnitrificantes e metanotróficas, mas o mecanismo envolvido foi considerado ser muito complexo. Nas análises cromatográficas por HPLC (cromatografia líquida de alta eficiência), ocorreu um pico no cromatograma que não correspondia a nenhum dos compostos intermediários conhecidos da oxidação aeróbia de metano. Dessa forma, os autores concluem que, sem o controle adequado do processo, nem mesmo toda a produção de metano de uma estação típica de tratamento de águas residuárias seria suficiente para prover o metano necessário para se alcançar a desnitrificação completa. Os autores consideram, também, bastante dispendiosa a oxidação de metano a compostos intermediários.

Além disso, ao longo de todos os experimentos realizados por Thalasso et al. (1997), na presença de metano e oxigênio, não foi observada formação de nitrito durante o processo de desnitrificação.

Apesar de a desnitrificação ter sido encontrada ocorrer simultaneamente à oxidação aeróbia de metano, Houbron et al. (1999) só detectaram desnitrificação considerável quando o fluxo de oxigênio cessou e sua concentração atingiu valores inferiores a $1,0 \mathrm{mg} / \mathrm{L}$.

Considera-se, portanto, questionável a afirmativa de que a etapa inicial da desnitrificação, através de metano, deva ocorrer, necessariamente, na presença de oxigênio.

Em experimentos posteriores aos publicados por Thalasso et al. (1997), o mesmo grupo de pesquisa operou reator desnitrificante (reator contínuo de mistura), utilizando metano como única fonte de carbono, na ausência de oxigênio. Os resultados obtidos são apresentados por Islas-Lima et al. (2002), em que os autores observaram que a eficiência da desnitrificação com metano foi tão alta quanto aquela obtida quando o 
doador de elétrons foi o acetato. Além disso, foi operado um reator controle, na ausência de metano, mas nenhuma desnitrificação foi observada. Esses estudos confirmaram que a desnitrificação, com o uso de metano como fonte de carbono, foi detectada ocorrer também na ausência de oxigênio.

\subsection{Cinética da desnitrificação}

A determinação de parâmetros cinéticos, através da obtenção das velocidades de utilização de substrato, apresenta-se como importante ferramenta para comparação entre diferentes doadores de elétrons, além de fornecer dados que podem ser utilizados para projetos de unidades de tratamento terciário.

A maioria dos estudos encontrados na literatura sobre cinética da desnitrificação apresenta parâmetros cinéticos aparentes, cuja determinação não considera a resistência à transferência de massa de substrato, do meio líquido para a superfície da partícula (transferência externa de massa) e desta para o seu interior (transferência interna de massa), o que torna a aplicação desses parâmetros restrita às condições para as quais foram determinados. Parâmetros cinéticos intrínsecos possuem aplicabilidade para condições mais diversas, por serem determinados em condições nas quais a influência da resistência à transferência de massa foi minimizada.

A velocidade de desnitrificação depende da natureza e da concentração da matéria carbonácea utilizada como doador de elétrons. Estudos anteriores (SHIEH e MULCAHY, 1986; ROS, 1995; VAN HAANDEL e MARAIS, 1999) confirmaram que a cinética da desnitrificação ocorreu segundo reação de ordem zero. No entanto, se a desnitrificação for considerada ocorrer através de duas etapas elementares: redução de nitrato a nitrito e redução de nitrito a nitrogênio gasoso, pode-se aplicar o conceito de reações múltiplas irreversíveis em série, apresentado por Silveira (1996). O modelo considerando que a desnitrificação ocorre através de reações de primeira ordem, tendo nitrito como o único produto intermediário, conforme a seqüência 3, está explicitado nas equações 1 , 2 e 3 . Tais equações foram obtidas a partir de balanço de massa em reator em batelada.

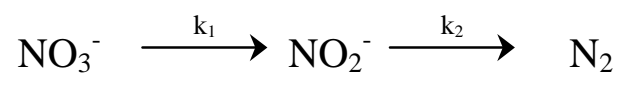

seq. 3 


$$
\begin{aligned}
& C_{\mathrm{NO}_{3}^{-}}=C_{\mathrm{NO}_{3}^{-} \mathrm{o}^{-}} \cdot e^{-k_{1} t} \\
& C_{\mathrm{NO}_{2}^{-}}=\frac{k_{1} C_{\mathrm{NO}_{3}^{-} \mathrm{o}}}{k_{2}-k_{1}} \cdot\left(e^{-k_{1} t}-e^{-k_{2} t}\right) \\
& C_{\mathrm{N}_{2}}=C_{\mathrm{NO}_{3}^{-} \mathrm{o}} \cdot\left[1+\frac{\left(k_{1} \cdot e^{-k_{1} t}-k_{2} \cdot e^{-k_{2} t}\right)}{k_{2}-k_{1}}\right]
\end{aligned}
$$

onde, $\quad C_{\mathrm{NO}_{3}^{-}}=$concentração de nitrato, $\mathrm{mg} / \mathrm{L}$

$\mathrm{C}_{\mathrm{NO}_{3}{ }^{-} \mathrm{o}}=$ concentração inicial de nitrato, $\mathrm{mg} / \mathrm{L}$

$\mathrm{C}_{\mathrm{NO}_{2}^{-}}=$concentração de nitrito, $\mathrm{mg} / \mathrm{L}$

$C_{N_{2}}=$ concentração de nitrogênio gasoso, $\mathrm{mg} / \mathrm{L}$

$\mathrm{k}_{1}=$ constante de saturação do nitrato

$\mathrm{k}_{2}=$ constante de saturação do nitrito

A obtenção de perfis temporais de concentração de nitrato e nitrito, para cada doador de elétrons, permite o ajuste das expressões (eq. 1, 2 e 3) aos dados experimentais, a partir das quais determinam-se os parâmetros cinéticos $\mathrm{k}_{1}$ e k2. Obtidos os valores dos parâmetros cinéticos, os diferentes doadores de elétrons podem ser comparados entre si. Caso o modelo proposto não represente bem os dados experimentais, outras combinações de reações de consumo de nitrato e nitrito devem ser avaliadas.

Vieira (1996) desenvolveu metodologia para determinação de parâmetros cinéticos intrínsecos em mesa rotativa incubadora (“shaker”). A utilização de biomassa imobilizada na forma de grânulos requer velocidade mínima de agitação de 200rpm, para minimização dos efeitos de transferência externa de massa. Além disso, o módulo de Thiele observado ( $\phi_{\mathrm{obs}}$ ) deve ser avaliado, visando minimizar a resistência à transferência interna de massa. Bailey e Ollis (1986) apresentam critério para avaliação da magnitude dos efeitos de transferência de massa intraparticular, baseado no módulo de Thiele observado:

$$
\phi_{o b s}=\frac{r_{o b s} X R_{e q}{ }^{2}}{9 D_{e} S_{b}}
$$


onde: $\quad \phi_{\text {obs }}=$ módulo de Thiele observado;

$\mathrm{r}_{\mathrm{obs}}=$ velocidade específica de utilização de substrato observada, $\left[\mathrm{T}^{-1}\right]$;

$\mathrm{X}=$ concentração de biomassa, $[\mathrm{M}] .[\mathrm{L}]^{-3}$;

$\mathrm{S}_{\mathrm{b}}=$ concentração de substrato no meio líquido, $[\mathrm{M}] .[\mathrm{L}]^{-3}$;

$\mathrm{R}_{\mathrm{eq}}=$ raio da esfera equivalente, [L].

De acordo com os autores, se o módulo de Thiele observado for menor que 0,3, a cinética global não estará limitada pela difusividade.

\subsection{Redução Dissimilativa de Nitrato à Amônia}

A desnitrificação é um processo importante na ciclagem de nitrogênio no meio ambiente. No entanto, nos reatores biológicos muitas vezes pode ocorrer competição entre os microrganismos responsáveis por algumas etapas do ciclo do nitrogênio. A redução de nitrato à amônia pode ser realizada, tanto para assimilação celular (anabolismo), quando nitrato é a única forma de nitrogênio disponível no meio, processo definido como redução assimilativa de nitrato à amônia, como também para utilização do substrato orgânico e redução de nitrato e nitrito à amônia. Neste último caso, conhecido com redução dissimilativa de nitrato à amônia (RDNA).

A RDNA foi, por muito tempo, confundida com a redução assimilativa de nitrato a amônia e seu processo não era muito estudado. Nos últimos 20 anos, tem sido constatado que a população responsável pela RDNA exerce grande influência nos reatores desnitrificantes e o processo foi reconhecido ser distinto do assimilativo.

Alguns termos têm sido utilizados para designar o processo catabólico de redução de nitrato a nitrogênio amoniacal, como: redução dissimilativa, dissimilatória e desassimilativa de nitrato a $\mathrm{N}$-amoniacal.

Os microrganismos que fazem a RDNA serão, neste trabalho, chamados de microrganismos produtores de amônia ou amonificadores.

De acordo com Tiedje (1988), o desenvolvimento da população de microrganismos responsáveis pela RDNA ocorre como resultado da competição entre os metabolismos fermentativo e respiratório. O principal fator que afeta a competição entre bactérias desitrificantes e produtoras de amônia é a proporção entre doador e aceptor de elétrons disponível. 
As equações 5 e 6 mostram que, para que ocorra a redução de nitrato à $\mathrm{N}_{2}$ (desnitrificação), são necessários 5 elétrons para promover o processo, enquanto que a RDNA utiliza 8 elétrons:

$$
\begin{array}{lll}
\mathrm{NO}_{3}{ }^{-}+5 \mathrm{e}^{-} \rightarrow \mathrm{N}_{2} & \text { (desnitrificação completa) } \\
\mathrm{NO}_{3}{ }^{-}+8 \mathrm{e}^{-} \rightarrow \mathrm{NH}_{4}^{+} & \text {(RDNA) } & \text { eq. } 5 \\
& \text { eq. } 6
\end{array}
$$

Em sistemas que apresentam baixa relação $\mathrm{C} / \mathrm{N}$, as bactérias desnitrificantes provavelmente devem ser favorecidas durante a competição, enquanto que, quando o doador de elétrons encontrar-se em excesso (C/N elevado), a RDNA deve ser preferida, pois o metabolismo dos microrganismos é um processo altamente regulado e a RDNA não será preferencialmente realizada quando o doador de elétrons não estiver em excesso.

Os resultados apresentados por Guynot et al. (1998) mostram que, para que os microrganismos que produzem N-amoniacal não tomem uma proporção importante entre a população que reduz nitrato, em reator desnitrificante, é importante alimentá-lo com substratos não fermentáveis e baixas proporções C/N. Além disso, os autores observaram que o lodo aeróbio apresentou maior proporção de desnitrificantes/amonificadoras que o anaeróbio. Por essa razão, tal lodo foi utilizado como inóculo no reator desnitrificante. Contudo, o valor da proporção mudou com o tempo de operação e, após 16 meses, a população de amonificadores esteve muito próxima da população de desnitrificantes.

\subsection{Suplementação de sistemas desnitrificantes com micronutrientes}

Sabe-se que os micronutrientes complementam os requerimentos nutricionais e melhoram o desempenho dos processos biológicos. São requeridos em pequenas quantidades, denominadas traço. Os micronutrientes são metais que desempenham papéis importantes sobre a atuação de várias enzimas.

Segundo Madigan et al. (1997), o ferro é o micronutriente mais importante e é requerido, pela célula, em maiores quantidades que os demais, devendo ser considerado macronutriente. O ferro desempenha papel importante na respiração celular, por ser um componente essencial para os citocromos e proteínas FeS envolvidas no transporte de elétrons. 
Na Tabela 1 são apresentados os principais micronutrientes requeridos pelas células e as funções celulares com as quais estão relacionados. É importante observar que nem todos os elementos listados são requeridos por todas as células; alguns metais listados são encontrados apenas nas enzimas de microrganismos específicos. De acordo com essa tabela, apenas os metais cobre, molibdênio, manganês, níquel, zinco e ferro desempenham funções nas células dos microrganismos desnitrificantes.

Tabela 1. Papel dos metais traço requeridos pelas células.

\begin{tabular}{|c|c|}
\hline Elemento & Presença / requerimento \\
\hline Cromo (Cr) & $\begin{array}{l}\text { Requerido pelos mamíferos para o } \\
\text { metabolismo da glicose, não é conhecido } \\
\text { como requerimento microbiano. }\end{array}$ \\
\hline Cobalto (Co) & $\begin{array}{l}\text { Vitamina } \mathrm{B}_{12} \text {; transcarboxilase (bactérias } \\
\text { do ácido propiônico). }\end{array}$ \\
\hline Cobre $(\mathrm{Cu})$ & $\begin{array}{l}\text { Certas proteínas, notavelmente aquelas } \\
\text { envolvidas na respiração, por exemplo, } \\
\text { oxidase do citocromo } c \text {; ou na fotossíntese. }\end{array}$ \\
\hline Manganês (Mn) & $\begin{array}{l}\text { Ativador de muitas enzimas; presente no } \\
\text { fotosistema II em fototróficos oxigênicos. }\end{array}$ \\
\hline Molibdênio (Mo) & $\begin{array}{l}\text { Presente em várias enzimas que contém } \\
\text { flavina; também na molibdênio } \\
\text { nitrogenase, nitrato redutase, sulfeto } \\
\text { oxidase, DMSO-TMAO redutase e } \\
\text { algumas desidrogenases do formiato. }\end{array}$ \\
\hline Níquel (Ni) & $\begin{array}{l}\text { Presente nas desidrogenases, coenzima } \mathrm{F}_{430} \\
\text { da metanogenese, desidrogenase do } \\
\text { monóxido de carbono e uréase. }\end{array}$ \\
\hline Selênio (Se) & $\begin{array}{l}\text { Formiato desidrogenase, } \\
\begin{array}{l}\text { hidrogenases e algumas } \\
\text { selenocisteína. }\end{array}\end{array}$ \\
\hline Tungstênio (W) & $\begin{array}{l}\text { Algumas desidrogenases do formiato; } \\
\text { oxotransferases de hipertermófilos. }\end{array}$ \\
\hline Vanádio (V) & Vanádio nitrogenase e bromoperoxidase. \\
\hline Zinco (Zn) & $\begin{array}{l}\text { Presente em enzimas anidrase carbônica, } \\
\text { álcool desidrogenase, RNA e DNA } \\
\text { polimerase e muitas proteínas do DNA. }\end{array}$ \\
\hline Ferro (Fe) & $\begin{array}{l}\text { Citocromos, catalases, peroxidases, } \\
\text { proteínas ferro-enxofre, oxigenases e todas } \\
\text { as nitrogenases. }\end{array}$ \\
\hline
\end{tabular}

Fonte: Madigan et al. (1997)

De acordo com Burgess et al. (1999), elementos traço fazem com que componentes das enzimas e seus co-fatores atuem na catálise das reações metabólicas e na manutenção da estrutura enzimática. Eles podem atuar, também, como enzimas metálicas ativadoras que, diferentemente das coenzimas, não fazem parte da reação que 
catalisam, mas são utilizados no transporte de elétrons dentro da célula. Os micronutrientes têm influência sobre a seleção das populações microbianas que crescem durante a degradação do resíduo e também na diversidade das espécies presentes.

\subsection{Diversidade microbiana - utilização de técnicas moleculares}

O conhecimento dos microrganismos envolvidos e das interações microbianas que ocorrem durante a desnitrificação é de fundamental importância para compreensão do processo, pois pode permitir sua otimização através do conhecimento das relações sintróficas que ocorrem em comunidades complexas. A aplicação de técnicas de Biologia Molecular para identificação da diversidade microbiana fornece informações sobre a estrutura e atividade microbianas não elucidadas através da utilização de técnicas de microbiologia e microscopia convencionais (ROSADO et al., 1997).

Em todas as células, os próprios genes são compostos por ácido desoxirribonucléico (DNA). A informação biológica está armazenada no DNA, como uma seqüência de bases nitrogenadas (MADIGAN et al., 1997). O gene $16 S$ é útil para os estudos de avaliação da diversidade microbiana, por estar presente em todas as células procariontes e conter regiões conservadas.

Métodos mais rápidos, como fingerprinting genético (análises de variabilidade genética de comunidades microbianas), utilizando a técnica de DGGE (eletroforese em gel de gradiente desnaturante), de fragmentos de DNAr 16S, amplificados por PCR (reação de polimerização em cadeia), fornecem visualização direta da diversidade filogenética com elevado poder de resolução. No entanto, embora esse tipo de análise permita avaliar a diversidade de microrganismos presente nos reatores, não possibilita inferir sobre a atividade desses microrganismos.

Para essa determinação, o primeiro passo é a extração do DNA da amostra, seguida de sua amplificação por PCR, gerando uma mistura de fragmentos de DNA, que representam todas as espécies presentes naquela amostra. Em seguida, a amostra é submetida à eletroforese em gel, com gradiente desnaturante (DGGE), para detectar alterações nos produtos de PCR (CATTONY, 2001).

Para a realização do DGGE, não é necessário o conhecimento prévio da comunidade microbiana presente na amostra. As moléculas são separadas, dentro de um gradiente químico de desnaturação, de acordo com a quantidade de ligações CG contida nas amostras de DNA. Durante a amplificação das amostras de DNA, por PCR, através 
da utilização de um primer universal, vários fragmentos de DNA amplificados são separados no gel (ligações CG) e aparecem representados por bandas. Cada banda observada no gel de DGGE representa, teoricamente, uma seqüência de DNA e por extensão, uma população microbiana (DABERT et al., 2002).

Como as bactérias nitrificantes são mais sensíveis a variações das condições ambientais e cargas de choque, essa população tem sido mais estudada por sua dificuldade de estabelecimento nos sistemas biológicos para remoção de nitrogênio. Poucos estudos que envolvam microrganismos desnitrificantes utilizando técnicas de Biologia Molecular têm sido realizados.

Além dos estudos de diversidade microbiana, os estudos com cultura pura são muito importantes por fornecer informações sobre as condições nutricionais e ambientais e sobre a cinética de crescimento de determinados microrganismos. Desta forma, fica mais fácil compreender o papel desses microrganismos quando se desenvolvem em culturas mistas e melhorar o desempenho dos reatores. 


\section{METODOLOGIA}

Para facilitar a compreensão dos ensaios realizados, este capítulo foi dividido por experimento, mantendo a seqüência em que estes foram realizados. O mesmo lodo foi utilizado para inocular os reatores, sendo que suas principais características estão descritas no item 5.1. A água residuária utilizada também foi sempre a mesma, para todos os ensaios e operação dos reatores.

A Tabela 2 apresenta o resumo dos experimentos realizados, em que são indicados as fontes de carbono utilizadas e os objetivos pretendidos com a realização dos mesmos.

Tabela 2. Descrição e objetivos dos experimentos realizados.

\begin{tabular}{|c|c|c|c|}
\hline \multicolumn{2}{|c|}{ Experimento } & $\begin{array}{c}\text { Tempo de } \\
\text { Operação } \\
\text { (meses) } \\
\end{array}$ & Objetivo \\
\hline $\begin{array}{c}\text { Reatores } \\
\text { anóxicos } \\
\text { comparativos } \\
(4 \mathrm{~L})\end{array}$ & $\begin{array}{c}\text { Etanol }(\mathrm{C} / \mathrm{N}=1,0) \\
\text { Etanol }(\mathrm{C} / \mathrm{N}=0,75) \\
\text { Etanol }(\mathrm{C} / \mathrm{N}=0,50) \\
\text { Metanol }(\mathrm{C} / \mathrm{N}=1,0) \\
\text { Metanol }(\mathrm{C} / \mathrm{N}=0,75) \\
\text { Metanol }(\mathrm{C} / \mathrm{N}=0,50) \\
\text { Metano (s/ oxigênio) } \\
\text { Metano (c/ oxigênio) }\end{array}$ & $\begin{array}{l}4 \\
2 \\
2 \\
4 \\
2 \\
2 \\
4 \\
2\end{array}$ & $\begin{array}{c}\text { Obter parâmetros cinéticos } \\
\text { aparentes, para serem utilizados } \\
\text { como ferramenta de comparação } \\
\text { entre as relações C/N e doadores } \\
\text { de elétrons e avaliar a diversidade } \\
\text { microbiana ao longo do tempo de } \\
\text { operação. }\end{array}$ \\
\hline $\begin{array}{c}\text { Reatores para } \\
\text { estudo cinético } \\
(250 \mathrm{~mL})\end{array}$ & $\begin{array}{c}\text { Etanol }(\mathrm{C} / \mathrm{N}=1,0) \\
\text { Etanol }(\mathrm{C} / \mathrm{N}=0,75) \\
\text { Metanol }(\mathrm{C} / \mathrm{N}=1,0) \\
\text { Metano (c/ oxigênio) }\end{array}$ & $\begin{array}{l}\text { Utilizados em } \\
\text { ensaios curtos } \\
\text { com duração de } \\
\text { algumas horas }\end{array}$ & $\begin{array}{l}\text { Obter parâmetros cinéticos } \\
\text { intrínsecos. Os frascos de } 250 \mathrm{~mL} \text {, } \\
\text { preenchidos com lodo proveniente } \\
\text { dos reatores de } 4 \mathrm{~L} \text {, foram } \\
\text { submetidos à agitação "shaker". }\end{array}$ \\
\hline $\begin{array}{l}\text { Reatores } \\
\text { anóxicos } \\
\text { alimentados } \\
\text { com metano } \\
(500 \mathrm{~mL})\end{array}$ & $\begin{array}{c}\text { Metano } \\
\text { Metano e oxigênio } \\
\text { Metano e metais } \\
\text { Metano, metais e } \\
\text { oxigênio } \\
\text { Controle (sem metano e } \\
\text { sem oxigênio) }\end{array}$ & 2 & $\begin{array}{c}\text { Verificar a influência do oxigênio } \\
\text { e da suplementação com metais } \\
\text { sobre a cinética da desnitrificação } \\
\text { através de metano e avaliar a } \\
\text { diversidade microbiana dos } \\
\text { reatores. }\end{array}$ \\
\hline
\end{tabular}


Além desses experimentos, foram realizados ensaios de purificação, com lodo proveniente dos reatores anóxicos alimentados com metano (Tabela 2), com o objetivo de obter culturas puras, tanto de microrganismos desnitrificantes utilizadores de metano, como de consórcios bacterianos compostos por organismos metanotróficos e desnitrificantes.

Os reatores anóxicos comparativos alimentados com etanol, metanol e metano, foram denominados RE, RM1 e RM2, respectivamente.

Na Figura 2 é apresentado o fluxograma dos experimentos, juntamente com os principais parâmetros que foram avaliados em cada reator desnitrificante.

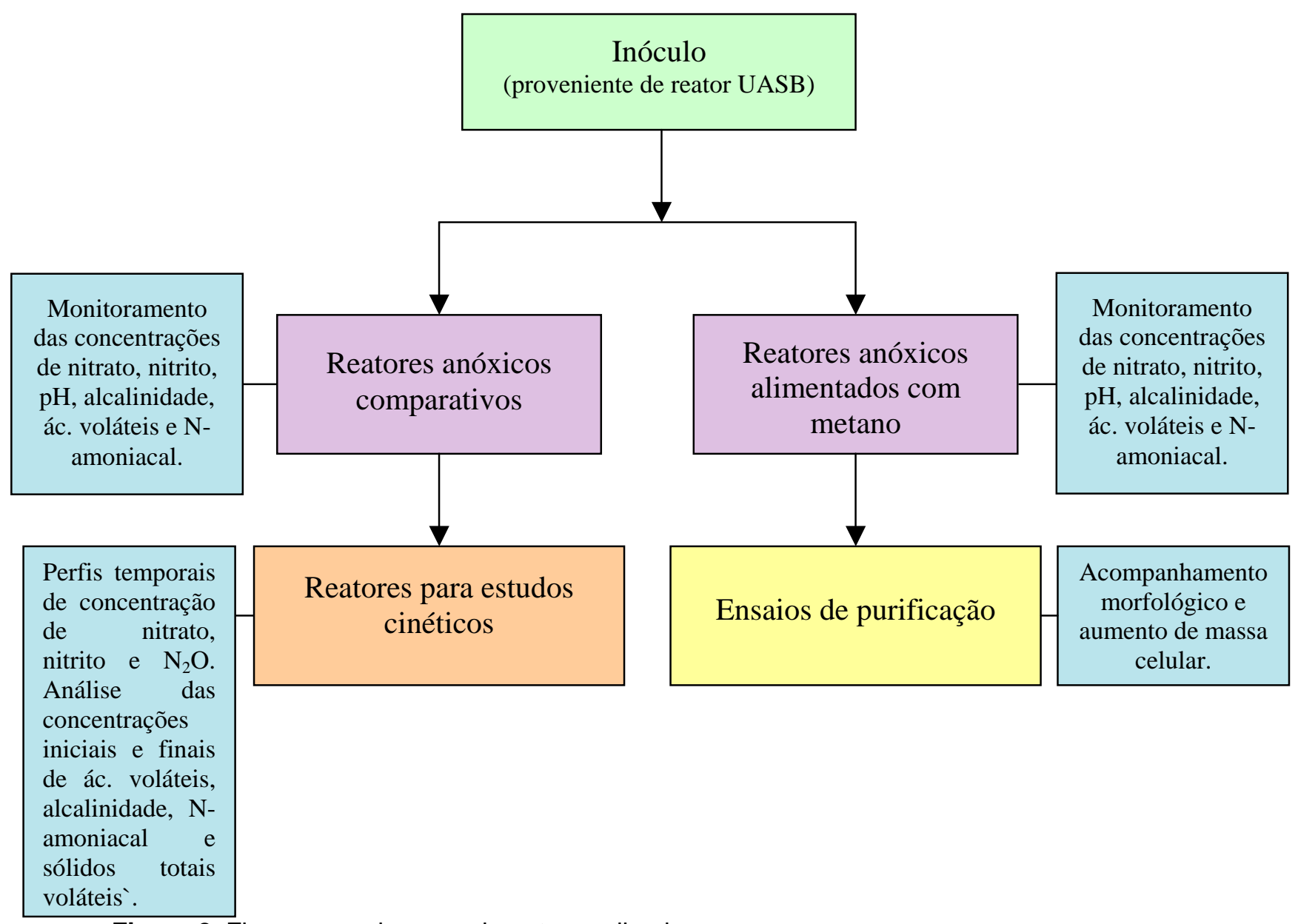

Figura 2. Fluxograma dos experimentos realizados

\subsection{Inóculo}

Os reatores foram inoculados com lodo anaeróbio granular proveniente de reator UASB utilizado para tratamento de efluente de abatedouro de aves. Este lodo tem sido intensivamente utilizado nas pesquisas realizadas no Laboratório de Processos Biológicos - LPB (EESC-USP) por apresentar grande diversidade de microrganismos. 


\section{2 Água residuária sintética}

A água residuária sintética utilizada foi preparada de maneira a simular efluente nitrificado de sistema de tratamento de esgotos sanitário (CALLADO, 2001) e contém os principais compostos normalmente presentes nesse tipo de efluente. A composição e as características desta água residuária estão apresentadas nas Tabelas 3 e 5 . Enquanto a composição da solução de sais minerais é apresentada na Tabela 4.

Tabela 3. Composição da água residuária sintética que simulou efluente nitrificado.

\begin{tabular}{cc}
\hline Constituinte & Concentração \\
\hline Nitrato de potássio $\left(\mathrm{KNO}_{3}\right)$ & $144,28 \mathrm{mg} / \mathrm{L}$ \\
Fosfato de potássio $\left(\mathrm{KH}_{2} \mathrm{PO}_{4}\right)$ & $74,58 \mathrm{mg} / \mathrm{L}$ \\
Sulfato de sódio $\left(\mathrm{Na}_{2} \mathrm{SO}_{4}\right)$ & $10,35 \mathrm{mg} / \mathrm{L}$ \\
Uréia $\left(\mathrm{CON}_{2} \mathrm{H}_{4}\right)$ & $8,57 \mathrm{mg} / \mathrm{L}$ \\
Bicarbonato de Sódio $\left(\mathrm{NaHCO}_{3}\right)$ & $100,00 \mathrm{mg} / \mathrm{L}$ \\
Sais minerais & $5,00 \mathrm{~mL} / \mathrm{L}$ \\
\hline
\end{tabular}

Tabela 4. Composição da solução de sais minerais na água residuária sintética.

\begin{tabular}{cc}
\hline Sais Minerais & Concentração (g/L) \\
\hline $\mathrm{NaCl}_{2}$ & 50,0 \\
$\mathrm{MgCl}_{2} \cdot 6 \mathrm{H}_{2} \mathrm{O}$ & 1,4 \\
$\mathrm{CaCl}_{2} \cdot 2 \mathrm{H}_{2} \mathrm{O}$ & 0,9 \\
\hline
\end{tabular}

Tabela 5. Características esperadas para a água residuária sintética

\begin{tabular}{cc}
\hline Componentes & Concentração (mg/L) \\
\hline $\mathrm{N}-\mathrm{NTK}$ & 4,0 \\
$\mathrm{~N}^{-N^{2}}$ & 20,0 \\
$\mathrm{SO}_{4}{ }^{2-}$ & 7,0 \\
$\mathrm{PO}_{4}{ }^{3-}$ & 17,0 \\
Alcalinidade $\left(\mathrm{CaCO}_{3}\right)$ & 100,0 \\
\hline $\mathrm{pH} \mathrm{7,5}$
\end{tabular}

\subsection{Experimentos com reatores anóxicos comparativos}

Foram utilizados três reatores anóxicos em batelada $(4 \mathrm{~L})$ preenchidos com 1,5 L de inóculo e 2,0 L de água residuária sintética, sendo de 0,5 L o volume do head-space (Figuras 3 e 4). Os reatores foram mantidos em câmara climatizada (Figura 5) com temperatura controlada de $30^{\circ} \mathrm{C} \pm 1^{\circ} \mathrm{C}$ e submetidos a ciclos de batelada de $24 \mathrm{~h}$. Os frascos eram dotados de dispositivos para a introdução e a retirada de líquido e gases, que permitiam a alimentação dos reatores com a água residuária, a retirada de efluentes tratados e de amostras de lodo, bem como a troca de gases do head-space pela passagem de fluxo de gás (metano ou nitrogênio) no interior dos mesmos. Além da água residuária sintético, cada reator recebeu uma dentre as seguintes fontes de carbono específicas: metanol, etanol ou metano. 


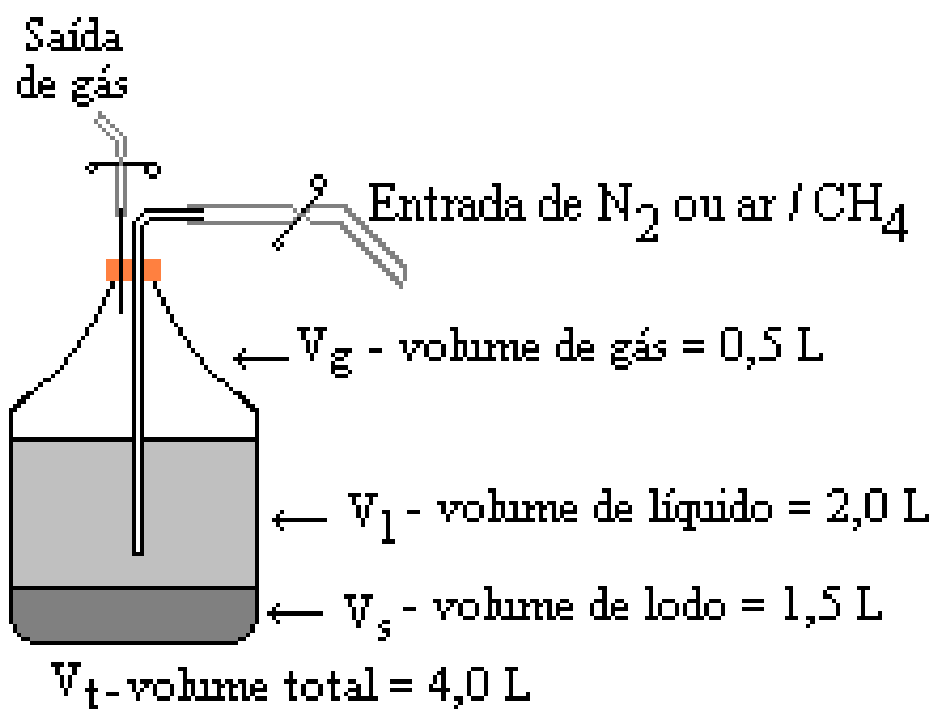

Figura 3. Esquema dos reatores anóxicos

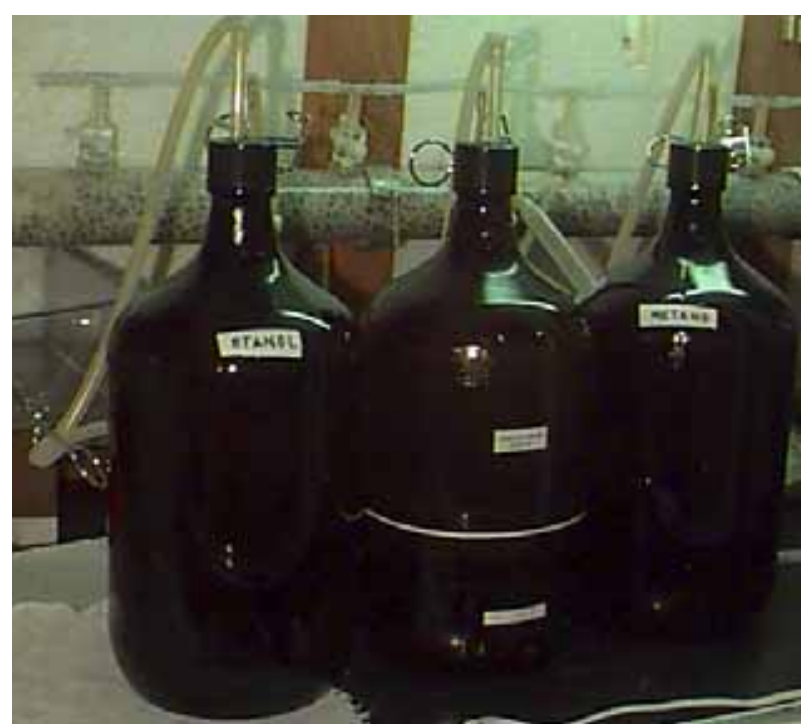

Figura 4. Foto dos reatores no interior da câmara

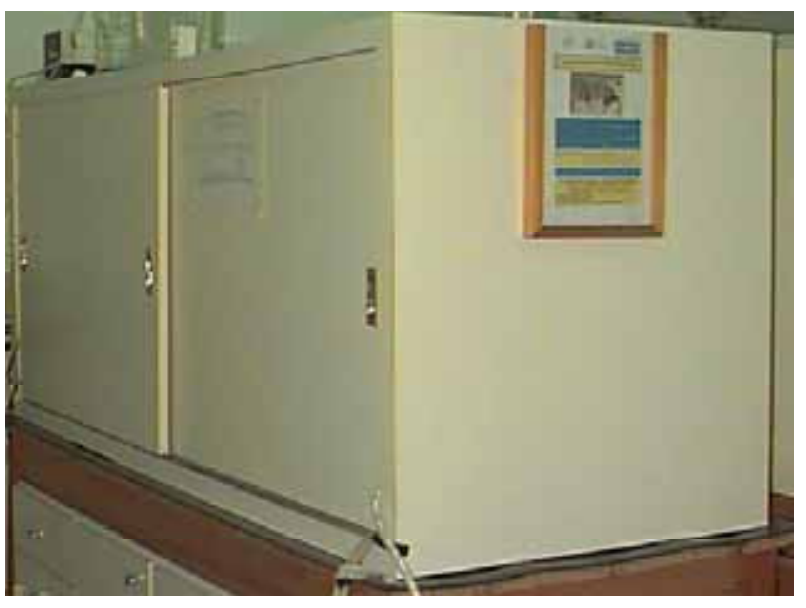

Figura 5. Foto do exterior da câmara climatizada

Os reatores alimentados com etanol e metanol foram operados durante 5 dias, mantendo-se a relação a $\mathrm{C} / \mathrm{N}$ igual 1,5. Em seguida, esta relação foi sendo diminuída ao longo do tempo de operação: $\mathrm{C} / \mathrm{N}$ igual 1,0, durante quatro meses; $\mathrm{C} / \mathrm{N}$ igual 0,75, por dois meses e $\mathrm{C} / \mathrm{N}$ igual 0,5 , por mais dois meses. As relações estequiométricas de desnitrificação para os doadores de elétrons, metanol e etanol são apresentadas nas equações 7 e 8 . O reator alimentado com metano foi operado, na presença de oxigênio, durante os quatro primeiros meses. Nos dois meses seguintes, foi operado na ausência de oxigênio. Na Figura 6 é apresentado esquema ilustrativo das condições de operação dos reatores anóxicos comparativos. 


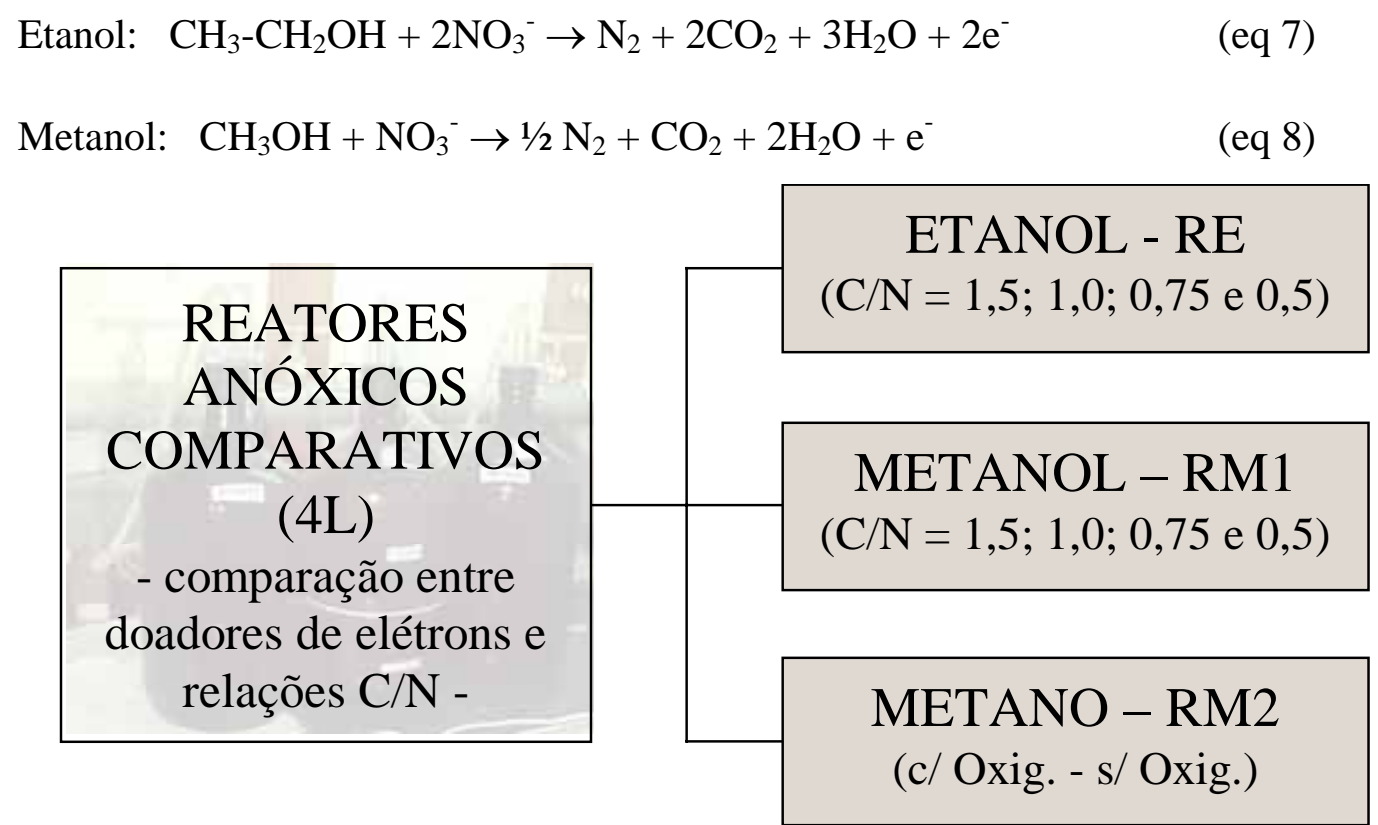

Figura 6. Esquema ilustrativo das condições de operação dos reatores anóxicos comparativos.

Após receberem a água residuária, a composição do gás no head-space foi alterada, com o objetivo de se evitar a contaminação com o meio ambiente ou a mistura com outros gases, garantindo-se, desse modo, a manutenção da atmosfera desejada. Os reatores contendo metanol e etanol foram submetidos à atmosfera de $N_{2}$ (100\%), durante os 5 primeiros minutos do ciclo de batelada. No caso do reator alimentado com metano, esse gás foi introduzido no reator e manteve-se presente no head-space, por constituir-se na fonte de carbono do processo de desnitrificação estudado. Por esse motivo, visando promover o desenvolvimento de bactérias metanotróficas, o reator foi submetido a mistura de, aproximadamente, 50\% de ar (introduzido através de compressor - atmosfera) e 50\% metano, durante 30 minutos, nos quatro primeiros meses de operação. Em seguida, foi operado por mais dois meses, substituindo-se a atmosfera gasosa de maneira a se obter 100\% de metano imediatamente após essa operação.

As concentrações iniciais das fontes de carbono, etanol e metanol, visaram a manutenção das relações $\mathrm{C} / \mathrm{N}$ utilizadas, conforme apresentado na Tabela 6. A concentração de nitrato esperada no meio foi de $20 \mathrm{mg}-\mathrm{N} / \mathrm{L}$, durante a variação da relação C/N. 
Tabela 6. Concentrações de etanol e metanol para as relações $\mathrm{C} / \mathrm{N}$ utilizadas

\begin{tabular}{cccccc}
\hline Fonte de carbono & $\begin{array}{c}\text { Densidade } \\
(\mathrm{g} / \mathrm{mL})-\end{array}$ & $\begin{array}{c}\text { Pureza } \\
(\%)\end{array}$ & $\begin{array}{c}\text { Concentração por relação C/N (mg/L) } \\
\mathbf{C} / \mathbf{N}=\mathbf{1 , 0}\end{array}$ & $\mathbf{C} / \mathbf{N}=\mathbf{0 , 7 5}$ & $\mathbf{C} / \mathbf{N}=\mathbf{0 , 5}$ \\
\hline Etanol $\left(\mathrm{CH}_{3} \mathrm{CH}_{2} \mathrm{OH}\right)$ & 0,791 & 99,5 & 38,3 & 28,8 & 19,2 \\
Metanol $\left(\mathrm{CH}_{3} \mathrm{OH}\right)$ & 0,792 & 99,8 & 53,3 & 40,0 & 26,7 \\
Concentração de nitrato esperada: $20 \mathrm{mg}-\mathrm{N} / \mathrm{L}$ & & & \\
\hline
\end{tabular}

Os ensaios para obtenção dos parâmetros cinéticos foram realizados após atingido o período de adaptação dos lodos às águas residuárias, ou seja, após as concentrações de nitrato e nitrito, presentes no efluente dos reatores, apresentarem variação pouco significativa entre uma batelada e outra. As amostras foram coletadas em intervalos de tempo regulares, para a obtenção de perfis de concentrações de nitrato e de nitrito ao longo do tempo.

Conforme ilustrado na Tabela 7, nos reatores alimentados com etanol e metanol, para a relação $\mathrm{C} / \mathrm{N}$ igual a 1,0, foi realizado um ensaio durante a fase de adaptação (fase A - após 2 meses de operação) e outro, com o sistema adaptado (fase B - após 4 meses de operação). Para as relações $\mathrm{C} / \mathrm{N}$ iguais a 0,75 e 0,5 , os reatores foram operados durante dois meses com cada relação e os ensaios foram realizados ao final de cada período de operação (fases C e D, respectivamente). No caso do reator alimentado com metano, os ensaios foram realizados nas fases A, B e C. Ao término da fase C, a operação deste reator foi finalizada.

Tabela 7. Esquema das fases em que foram realizados os perfis temporais de concentração de nitrato e de nitrito.

\begin{tabular}{cccc}
\hline \multirow{2}{*}{ Fase } & \multicolumn{3}{c}{ Doador de elétrons } \\
\cline { 2 - 4 } & Etanol & Metanol & Metano \\
\hline A (adaptação) & $\mathrm{C} / \mathrm{N}=1,00$ & $\mathrm{C} / \mathrm{N}=1,00$ & com oxigênio \\
$\mathrm{B}$ & $\mathrm{C} / \mathrm{N}=1,00$ & $\mathrm{C} / \mathrm{N}=1,00$ & com oxigênio \\
$\mathrm{C}$ & $\mathrm{C} / \mathrm{N}=0,75$ & $\mathrm{C} / \mathrm{N}=0,75$ & sem oxigênio \\
$\mathrm{D}$ & $\mathrm{C} / \mathrm{N}=0,50$ & $\mathrm{C} / \mathrm{N}=0,50$ & - \\
\hline
\end{tabular}

Durante o período de monitoramento dos reatores, os parâmetros $\mathrm{pH}$, alcalinidade, ácidos voláteis, nitrato e nitrito foram analisados três vezes por semana. Os sólidos totais e voláteis, presentes no licor misto, foram analisados apenas no final das fases $A, B, C$ e D.

Foi realizada a quantificação celular através da técnica de número mais provável (NMP) no lodo de inóculo e no final da fase B, em todos os reatores, objetivando comparar a quantidade de microrganismos desnitrificantes entre os reatores ensaiados. 
O acompanhamento da evolução das morfologias presentes no lodo dos reatores foi realizado através de microscopia óptica comum e de contraste de fase, em microscópio Olympus (BX 60). No início da operação e antes da mudança de cada fase, foram coletadas amostras do lodo para realização da análise da diversidade microbiana através da técnica de DGGE.

\subsection{Experimentos com reatores para estudo cinético}

No final das fases B e C, descritas no item 5.3, foram retiradas amostras de lodo de cada reator anóxico de $4 \mathrm{~L}$, alimentados com metanol, etanol e metano e realizados os ensaios que visaram à obtenção de parâmetros cinéticos intrínsecos de desnitrificação.

Os experimentos foram realizados em mesa rotativa incubadora ("shaker”), com temperatura controlada em $30{ }^{\circ} \mathrm{C} \pm 1{ }^{\circ} \mathrm{C}$, utilizando-se erlenmeyers de $250 \mathrm{~mL}$ (Figuras 7a e 7b), devidamente adaptados para manter condições anóxicas no meio líquido. Cada frasco recebeu 20 g de lodo úmido (aproximadamente $20 \mathrm{~mL}$ ); $70 \mathrm{~mL}$ de água residuária sintética, sendo de $170 \mathrm{~mL}$ o volume destinado à fase gasosa head-space.

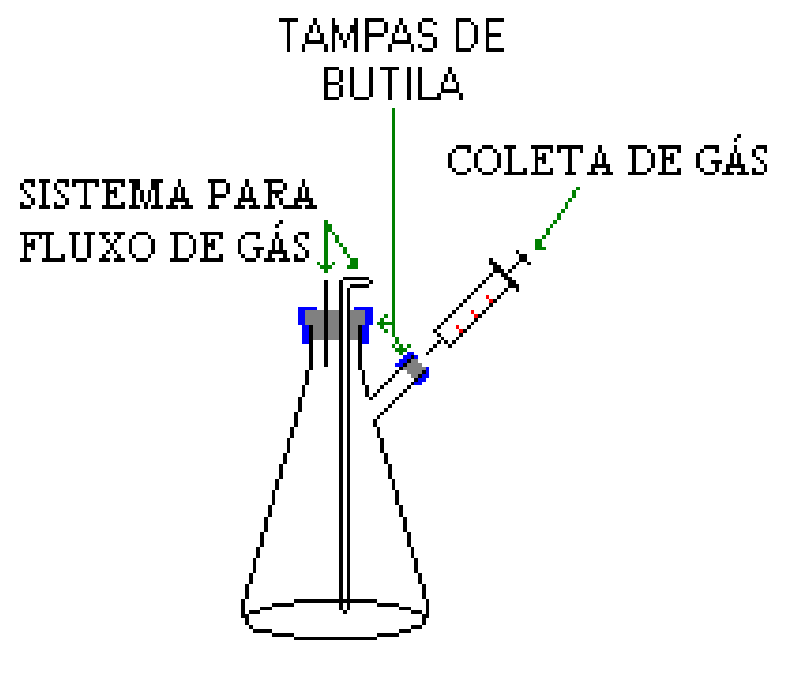

(a)

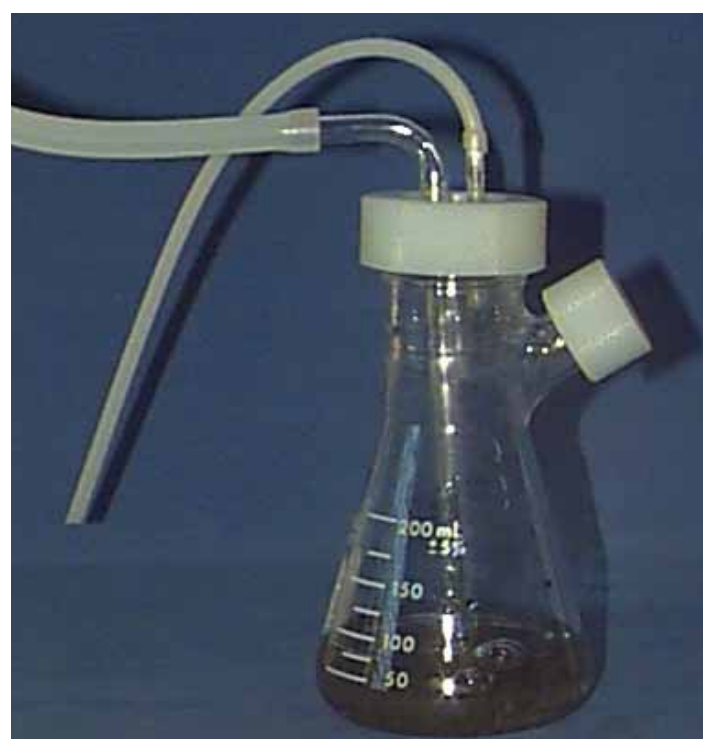

(b)

Figura 7. Frascos tipo erlenmeyer utilizados nos ensaios para determinação de parâmetros cinéticos intrínsecos: (a) esquema; (b) foto

De acordo com metodologia proposta por Vieira (1996) a aplicação, ao “shaker”, de velocidade de agitação igual ou superior a 150 rpm minimiza os efeitos da resistência externa à transferência de massa. A minimização dos efeitos da resistência interna à transferência de massa é realizada através da análise do módulo de Thiele observado (eq. 4). 
Foram utilizados 13 frascos iguais, retirados, um a um, do "shaker", em intervalos de tempo determinados, para a obtenção dos perfis temporais de concentração de nitrato, nitrito e $\mathrm{N}_{2} \mathrm{O}$. Além destes, mais dois frascos foram utilizados como controle, denominados C1 e C2. O frasco C1 não recebeu nenhuma fonte externa de carbono, pois se pretendia verificar a possível ocorrência de desnitrificação através da utilização de fontes internas de carbono (resultantes de processos endógenos). O frasco C2 não recebeu adição de nitrato, pois o objetivo era verificar a possível ocorrência de competição entre bactérias desnitrificantes e arqueas metanogênicas pela fonte de carbono.

Nos ensaios com lodo proveniente dos reatores de 4 L, RE e RM1, todos os frascos foram submetidos à seguinte seqüência de operação, antes de serem colocados no "shaker":

1. Introdução de $20 \mathrm{~g}$ de lodo, provenientes dos reatores de $4 \mathrm{~L}$, previamente centrifugados e pesados diretamente nos frascos;

2. Adição de $60 \mathrm{~mL}$ de água residuária sintética em cada frasco, concentradas para $70 \mathrm{~mL}$, de forma que quando misturadas aos $10 \mathrm{~mL}$ da fonte de carbono (etanol ou metanol) resultou na concentração pretendida;

3. Troca da composição gasosa no head-space. Neste passo, os frascos foram submetidos a um fluxo contínuo de nitrogênio (100\%), durante 3 minutos. Em seguida, o sistema previsto para permitir o fluxo de gás no interior do frasco (Figura 7a) foi fechado;

4. Injeção de $30 \mathrm{~mL}$ de acetileno, com o objetivo de bloquear a via metabólica que leva $\mathrm{N}_{2} \mathrm{O}$ para $\mathrm{N}_{2}$;

5. Colocação dos frascos no "shaker";

6. Adição de $10 \mathrm{~mL}$ de metanol ou etanol, em cada frasco (com exceção do frasco C1), através de seringa de plástico, para se obter a concentração desejada da fonte de carbono;

7. Retirada de um frasco e coleta de amostras das fases gasosa e líquida para realização das análises. Os resultados obtidos a partir das análises de amostras deste frasco foram considerados como representativos do tempo zero (inicial). 
O local de coleta de gás (Figura 7a) foi mantido fechado durante todo o tempo de ensaio, desde seu início.

Quando o metano foi utilizado como doador de elétrons, a mesma seqüência foi aplicada nos ensaios, com as seguintes exceções: no passo 2, foram adicionados $70 \mathrm{~mL}$ de água residuária, sem necessidade de concentrar; no passo 3, para a fase $\mathrm{B}$, uma mistura de ar (50\%) e metano (50\%) foi mantida no sistema durante 5 minutos, enquanto que, na fase $\mathrm{C}$, o gás utilizado na troca da atmosfera do head-space continha apenas metano (100\%); o frasco controle (C1) foi submetido a atmosfera de $100 \%$ de nitrogênio; o passo 6 não foi realizado.

Ao final dos ensaios, o lodo era retirado dos frascos e devolvido aos reatores de 4 L (RE, RM1 e RM2).

As análises de $\mathrm{pH}$, alcalinidade e ácidos voláteis foram realizadas apenas nas amostras do ponto zero (início), do último ponto (final) e dos frascos controle. Os parâmetros que foram analisados em todas as amostras são apresentados na Tabela 8, para cada doador de elétrons específico.

Tabela 8. Parâmetros analisados para cada doador de elétrons específico

\begin{tabular}{cccc}
\hline \multirow{4}{*}{$\begin{array}{c}\text { Parâmetros } \\
\text { analisados }\end{array}$} & Etanol & Metanol & Metano \\
\cline { 2 - 4 } & etanol, nitrato, nitrito, & metanol, nitrato, & metano, nitrato, \\
& $\mathrm{N}_{2} \mathrm{O}$ e sólidos totais, & nitrito, $\mathrm{N}_{2} \mathrm{O}$ e & nitrito, $\mathrm{N}_{2} \mathrm{O}$ e \\
& fixos e voláteis & sólidos totais, fixos & sólidos totais, fixos \\
& e voláteis & e voláteis \\
\hline
\end{tabular}

\subsection{Experimentos com reatores anóxicos alimentados com metano}

Foram utilizados cinco reatores anóxicos (concebidos em fracos de Duran de 500mL), preenchidos com $150 \mathrm{~mL}$ do lodo de inóculo, $200 \mathrm{~mL}$ de água residuária sintética e $150 \mathrm{~mL}$ de head-space (Figura 8). Os reatores foram operados em ciclos de batelada de 24 h e mantidos em câmara rotativa incubadora (“shaker”), sob agitação contínua de $150 \mathrm{rpm}$ e temperatura controlada de $30{ }^{\circ} \mathrm{C} \pm 1{ }^{\circ} \mathrm{C}$. 


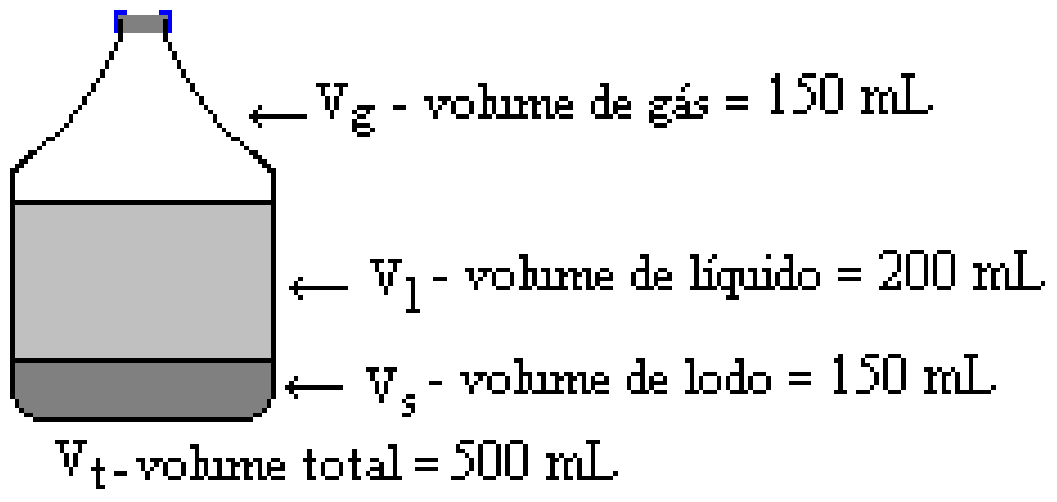

(a)

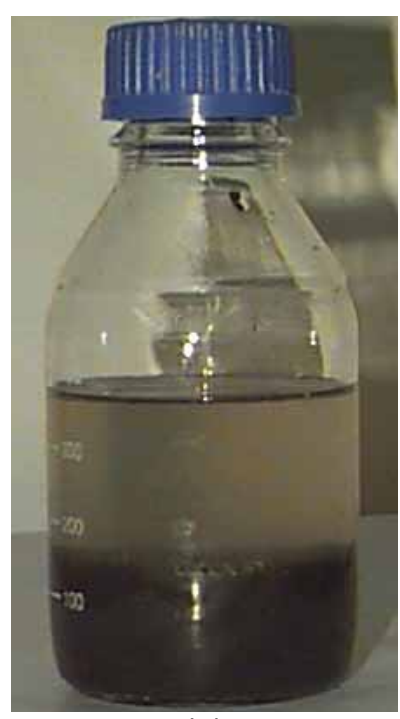

(b)

Figura 8. Reatores anóxicos utilizados nos ensaios de desnitrificação com metano: (a) esquema ilustrativo, (b) reatores anóxicos

Além da água residuária sintética, cada reator foi submetido a uma condição nutricional diferente, conforme apresentado na Tabela 9 e ilustrado na Figura 9. O pH da água residuária foi mantido em 7,5.

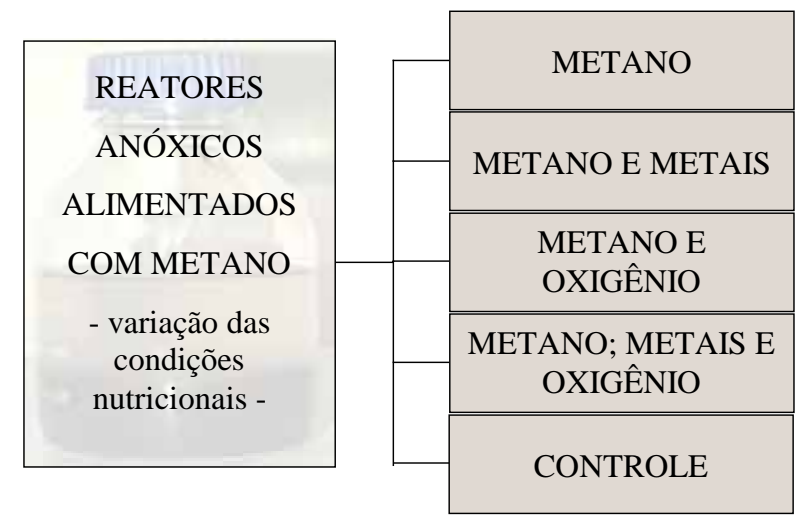

Figura 9. Esquema ilustrativo das variações nutricionais

Após receberem a água residuária, a solução traço mineral (reatores MM e MMO) e serem submetidos à atmosfera gasosa, os reatores foram fechados com tampa de butila e rosca plástica. Em seguida, os reatores MO e MMO receberam $5 \mathrm{~mL}$ de oxigênio puro, injetados através de seringa de plástico. A concentração de oxigênio introduzida nos reatores (5 mL de oxigênio puro/150 mL de head-space - pressão atmosférica) foi determinada como sendo a quantidade de oxigênio necessária para promover a conversão de metano a metanol, pelo fato de ser este o principal composto produzido por bactérias metanotróficas a partir de metano e oxigênio. 
Os reatores MM e MMO foram suplementados com solução traço mineral (10 mL/L), cuja composição está apresentada na Tabela 10. A suplementação com micronutrientes teve caráter exploratório, não visou a investigação da influência de metais específicos.

Tabela 9. Descrição das condições nutricionais dos reatores anóxicos alimentados com metano.

\begin{tabular}{|c|c|c|c|c|}
\hline Reator & $\begin{array}{l}\text { Fonte de carbono e } \\
\text { doador de elétrons }\end{array}$ & $\begin{array}{l}\text { Atmosfera } \\
\text { gasosa* }\end{array}$ & $\begin{array}{l}\text { Oxigênio } \\
\text { puro }\end{array}$ & $\begin{array}{l}\text { Metais } \\
\text { traços }\end{array}$ \\
\hline Metano (M) & Metano & $100 \%$ de $\mathrm{CH}_{4}$ & Ausente & Ausente \\
\hline Metano e oxigênio (MO) & Metano & $\begin{array}{c}100 \% \text { de } \mathrm{CH}_{4}+ \\
\text { oxigênio }\end{array}$ & Presente & Ausente \\
\hline Metano e metais (MM) & Metano & $100 \%$ de $\mathrm{CH}_{4}$ & Ausente & Presente \\
\hline Metano, metais e oxigênio (MMO) & Metano & $\begin{array}{c}100 \% \text { de } \mathrm{CH}_{4}+ \\
\text { oxigênio }\end{array}$ & Presente & Presente \\
\hline Controle (C) & sem adição externa & $100 \%$ de $\mathrm{N}_{2}$ & Ausente & Ausente \\
\hline
\end{tabular}

* Os reatores foram submetidos à atmosfera gasosa (metano/nitrogênio) durante 5 minutos.

Tabela 10. Composição da solução traço mineral

\begin{tabular}{cc}
\hline Composto & Concentração $(\mathrm{g} / \mathrm{L})$ \\
\hline Ácido nitriloacético (NTA) & 12,8 \\
$\mathrm{FeCl}_{3} \cdot 6 \mathrm{H}_{2} \mathrm{O}$ & 1,35 \\
$\mathrm{MnCl}_{2} \cdot 4 \mathrm{H}_{2} \mathrm{O}$ & 0,1 \\
$\mathrm{CoCl}_{2} \cdot 6 \mathrm{H}_{2} \mathrm{O}$ & 0,024 \\
$\mathrm{CaCl}_{2} \cdot 2 \mathrm{H}_{2} \mathrm{O}$ & 0,1 \\
$\mathrm{ZnCl}_{2}$ & 0,1 \\
$\mathrm{CuCl}_{2} \cdot 2 \mathrm{H}_{2} \mathrm{O}$ & 0,025 \\
$\mathrm{H}_{3} \mathrm{BO}_{3}$ & 0,01 \\
$\mathrm{Na}_{2} \mathrm{MoO}_{4} \cdot \mathrm{H}_{2} \mathrm{O}$ & 0,024 \\
$\mathrm{NaCl}$ & 1,0 \\
$\mathrm{Na}_{2} \mathrm{SeO}_{3} \cdot 5 \mathrm{H}_{2} \mathrm{O}$ & 0,026 \\
$\mathrm{NiCl}_{2} \cdot 6 \mathrm{H}_{2} \mathrm{O}$ & 0,12 \\
\hline
\end{tabular}

Fonte: Adaptado de Zinder et al. (1984)

Os ensaios para obtenção dos parâmetros cinéticos foram realizados após dois meses de operação, quando as concentrações de nitrato e nitrito remanescentes não apresentavam variação significativa entre uma batelada e outra. As amostras foram coletadas em intervalos de tempo, para a obtenção de perfis de concentrações de nitrato, nitrito e $\mathrm{N}_{2} \mathrm{O}$ ao longo do tempo.

$\mathrm{O}$ método de inibição do acetileno $\left(\mathrm{C}_{2} \mathrm{H}_{2}\right)$ foi empregado para verificação da via metabólica utilizada pelos microrganismos, através da observação da produção de $\mathrm{N}_{2} \mathrm{O}$ (YOSHINARI e KNOWLES, 1976). 
Durante o período de monitoramento dos reatores, os parâmetros $\mathrm{pH}$, alcalinidade, ácidos voláteis, nitrato e nitrito foram analisados três vezes por semana. As concentrações de sólidos totais, voláteis e fixos, presentes no líquido sob mistura, foram determinadas apenas no final dos ensaios, visando à obtenção dos parâmetros cinéticos.

Nas fases inicial e final, foram realizadas análises de microscopia eletrônica de varredura (MEV) e coletadas amostras do lodo para realização da análise da diversidade microbiana através da técnica de DGGE.

\subsection{Ensaio de purificação}

Foi realizado ensaio de purificação com amostras de lodo provenientes dos reatores anóxicos, de $500 \mathrm{~mL}$, alimentados com metano (item 5.5), com o objetivo de selecionar consórcios de bactérias metanotróficas e desnitrificantes, bem como microrganismos capazes de utilizar metano diretamente para a desnitrificação (desnitrificantes utilizadores de metano). Adicionalmente, cada amostra de lodo foi incubada na presença de nitrato e de nitrito com o objetivo de verificar possíveis diferenças entre as populações redutoras de nitrato e as redutoras de nitrito. Desta forma, foram utilizadas duas amostras de lodo para cada reator (M, MO, MM, MMO e C), o que resultou no total de 10 amostras, submetidas a esse tipo de ensaio, conforme ilustrado na Figura 10.

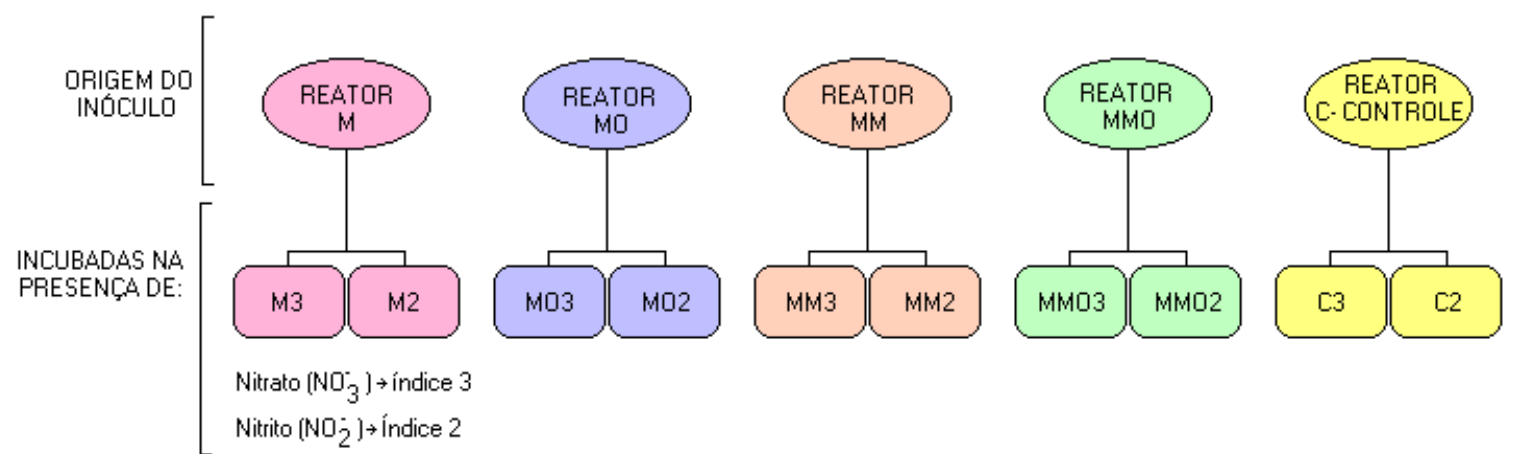

Figura 10. Esquema ilustrativo das amostras incubadas no ensaio de purificação.

Foram utilizados frascos de antibiótico de $30 \mathrm{~mL}$ e tampas de butila, lavadas com solução de bicarbonato de sódio 2\%. Todo material utilizado para incubar as amostras (inclusive a vidraria e as membranas) foi previamente esterilizado em autoclave. O meio utilizado para crescimento dos microrganismos foi a própria água 
residuária sintética, preparada em água milli-q e esterilizada através de filtração em membrana de $0,22 \mu \mathrm{m}$. As amostras foram incubadas em ambiente estéril.

Os ensaios para obtenção dos perfis temporais de concentração de nitrato e nitrito, realizados para os reatores $\mathrm{M}, \mathrm{MO}, \mathrm{MM}, \mathrm{MMO}$ e $\mathrm{C}$, conforme descrito no item 5.5, indicaram que a máxima concentração de nitrito atingida nestes perfis diferiu entre os reatores. Por esse motivo, de acordo com a origem do lodo, a concentração inicial de nitrito foi diferente entre as amostras incubadas e, aproximadamente, igual ao maior valor de $\mathrm{N}$-nitrito, observado nos perfis temporais de nitrito realizados com os reatores M, MO, MM, MMO e C. Nitrito de sódio $\left(\mathrm{NaNO}_{2}\right)$ foi utilizado para promover as concentrações de N-nitrito apresentadas na Tabela 11.

Tabela 11. Concentração de nitrito utilizada para cada amostra

\begin{tabular}{cccc}
\hline \multirow{2}{*}{ Origem do inóculo } & \multicolumn{3}{c}{ Reator } \\
\cline { 2 - 4 } & Controle (C) & M e MO & MM e MMO \\
\hline $\begin{array}{c}\text { Concentração de } \\
\mathrm{N}^{-} \mathrm{NO}_{2}{ }^{-}(\mathrm{mg} / \mathrm{L})\end{array}$ & 8,0 & 5,0 & 2,0 \\
\hline
\end{tabular}

Os meios de cultura utilizados (águas residuárias sintéticas) foram diferentes para cada amostra, em função dos objetivos fixados para esses ensaios. As principais diferenças entre as condições nutricionais impostas a cada amostra incubada são apresentadas na Tabela 12. A água residuária sintética (item 5.2) foi a base dos meios de cultura, utilizada em todas as amostras, ocorrendo a substituição de compostos (nitrato por nitrito), adição de metais e de oxigênio, ou de ambos, dependendo da origem do lodo.

Tabela 12. Condições nutricionais utilizadas de acordo com a origem do inóculo.

\begin{tabular}{|c|c|c|c|c|c|c|c|c|c|c|}
\hline \multirow{2}{*}{ Amostra } & \multicolumn{5}{|c|}{ Nitrato (3) } & \multicolumn{5}{|c|}{ Nitrito (2) } \\
\hline & M3 & MO3 & MM3 & MMO3 & C3 & M2 & MO2 & MM2 & MMO2 & $\mathrm{C} 2$ \\
\hline \multirow{4}{*}{$\begin{array}{l}\text { Condições } \\
\text { nutricionais }\end{array}$} & Nitrato & Nitrato & Nitrato & Nitrato & Nitrato & Nitrito & Nitrito & Nitrito & Nitrito & Nitrito \\
\hline & Metano & Metano & Metano & Metano & $\mathrm{N}_{2}$ & Metano & Metano & Metano & Metano & $\mathrm{N}_{2}$ \\
\hline & & $\mathrm{O}_{2}$ & Metais & Metais & & & $\mathrm{O}_{2}$ & Metais & Metais & \\
\hline & & & & $\mathrm{O}_{2}$ & & & & & $\mathrm{O}_{2}$ & \\
\hline
\end{tabular}


Cada uma das dez amostras foi incubada de acordo com o seguinte procedimento:

1. O meio de cultura foi filtrado (kit de filtração Millipore) e mantido sob fluxo de gás (100\% de metano para M, MO, MM e MMO ou 100\% de $\mathrm{N}_{2}$, para C controle) durante 3 minutos;

2. $10 \mathrm{~mL}$ de água residuária foram retiradas, utilizando-se pipeta de vidro, e adicionadas aos frascos de antibiótico;

3. Cada frasco foi mantido sob fluxo de gás por 1 minuto;

4. Os frascos foram tampados com tampa de butila, e lacrados com selo de alumínio;

5. O lodo granular dos reatores de $500 \mathrm{~mL}$ (item 5.5), foi macerado para desfazer os grânulos;

6. $1 \mathrm{~mL}$ de lodo macerado foi inserido em frasco de antibiótico, que continha $10 \mathrm{~mL}$ de meio, utilizando-se seringa de $1 \mathrm{~mL}$. Este frasco representou a diluição $10^{-1}$;

7. $1 \mathrm{~mL}$ foi retirado do frasco de diluição $10^{-1}$ e inserido em outro frasco de antibiótico que continha $10 \mathrm{~mL}$ de meio e constituiu a diluição $10^{-2}$;

8. Este procedimento foi repetido até que a diluição $10^{-10}$ fosse atingida;

9. $0,7 \mathrm{~mL}$ de oxigênio puro $\left(100 \%\right.$ de $\left.\mathrm{O}_{2}\right)$ foram inseridos nos frascos das dez diluições incubadas com amostras de MO3, MO2, MMO3 e MMO2.

Após a realização deste procedimento, todos os frascos foram mantidos em incubadora, à temperatura controlada de $30^{\circ} \mathrm{C} \pm 1{ }^{\circ} \mathrm{C}$, sem agitação. Diariamente eram realizadas observações visuais dos frascos e os que se apresentavam turvação eram retirados e mantidos em geladeira. Os registros das morfologias presentes, nos frascos com turvação, foram feitos através da observação de amostras em microscópio Olympus (BX 60), sob contraste de fase e microscopia óptica comum.

Em seguida, para as amostras com turvação das maiores diluições de cada condição, promoveu-se o crescimento da massa celular, aumentando-se o volume dos frascos e da fase líquida, sob condições de assepsia, e mantendo-se a proporção de 50\% do volume do frasco como head-space e 50\% de fase líquida (células e meio de cultura). 
Na Tabela 13 é apresentado o resumo da situação final das culturas purificadas, obtidas para cada condição nutricional. O volume de células apresentado nesta tabela refere-se ao volume líquido, em que as células encontram-se dispersas no meio, em baixas concentrações, conforme pode ser observado na Figura 11, para amostra de MMO3.

Tabela 13. Volume de células purificadas obtidas para cada condição nutricional

\begin{tabular}{ccccccccccc}
\hline Amostra & M3 & M2 & MO3 & MO2 & MM3 & MM2 & MMO3 & MMO2 & C3 & C2 \\
\hline $\begin{array}{c}\text { Volume } \\
\text { (mL) }\end{array}$ & 80 & 80 & 80 & 80 & 130 & 80 & 1000 & 1000 & 80 & 80 \\
\hline
\end{tabular}

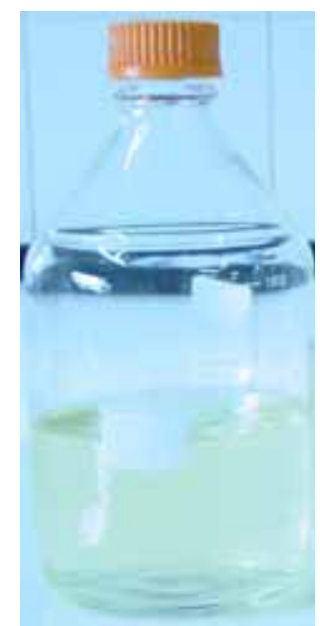

Figura 11. Reator desnitrificante com cultura purificada, amostra MMO3.

\subsubsection{Crescimento das culturas em meio sólido}

As culturas obtidas com as amostras MMO3 e MMO2 foram submetidas a crescimento em meio sólido (placa de Petri), com o objetivo de se verificar a forma de crescimento dessas células em colônia, bem como a possível presença de microrganismos indesejáveis, indicativos de contaminação das amostras durante os ensaios.

Todo o material utilizado, placas de Petri, vidraria, pinças, membranas, etc., foi previamente esterilizado em autoclave. O procedimento descrito, a seguir, foi realizado duas vezes, uma na presença de nitrato (para MMO3) e outra, na presença de nitrito (para MMO2):

1. Foram preparadas $400 \mathrm{~mL}$ de água residuária sintética, com concentração para $500 \mathrm{~mL}$ e esterilizadas por filtração em membrana 0,22 $\mu \mathrm{m}$; 
2. $100 \mathrm{~mL}$ de agar concentrados para $500 \mathrm{~mL}$ foram preparados em água milliq, e autoclavados (a concentração final do agar, após mistura com a água residuária sintética, foi de 1,3\%);

3. Imediatamente após o agar ter sido retirado da autoclave, foi misturado, ainda quente, aos 400 mL de água residuária, já filtrada;

4. Os $500 \mathrm{~mL}$ de meio foram submetidos a fluxo de metano (100\%) durante 5 minutos;

5. O meio foi distribuído nas placas de Petri (em triplicata) até preencher aproximadamente a metade das placas;

6. Tão logo o meio tornou-se sólido, devido ao resfriamento, uma amostra das culturas foi espalhada na placa (estriamento), utilizando alça de platina;

7. As amostras foram incubadas em jarra de acrílico e mantidas em incubadora, com temperatura controlada de $30^{\circ} \mathrm{C} \pm 1^{\circ} \mathrm{C}$;

Observado o crescimento de culturas nas placas, estas foram retiradas da incubadora e uma colônia foi retirada do meio sólido (através de alça de platina) e sua morfologia foi observada em microscópio. A placa de Petri também foi examinada ao microscópio, para observação da forma da colônia.

Em seguida, uma colônia foi extraída do meio sólido e sob condições de assepsia, foi introduzida no meio líquido (frascos de antibiótico de 30mL). A partir daí, esse volume foi aumentado até 1000mL, como apresentado na Tabela 13, para MMO3 e MMO2. As demais culturas não foram submetidas a crescimento em meio sólido.

\subsubsection{Ensaio para obtenção da cinética de crescimento celular}

Foi realizado ensaio cinético com a cultura purificada da amostra MMO3, na presença de metano, metais, nitrato e oxigênio, para obtenção de dados sobre a cinética de crescimento dos microrganismos. O ensaio foi realizado em duplicata. O procedimento utilizado nesse ensaio cinético encontra-se descrito a seguir:

1. $800 \mathrm{~mL}$ do volume de células da amostra MMO3 foram centrifugados em tubos falcon (15 mL), em centrífuga refrigerada a 6000 rpm por 5 minutos;

2. As células foram ressuspendidas em $400 \mathrm{~mL}$ de cloreto de sódio (0,9\%);

3. 2L do mesmo meio de cultura que vinha sendo utilizado foi filtrado em membrana de $0,22 \mu \mathrm{m}$; 
4. $900 \mathrm{~mL}$ de meio foram introduzidos em cada frasco de Duram de 2L (total de 2 frascos);

5. Os meios foram submetidos à atmosfera de metano, durante 5 minutos;

6. $100 \mathrm{~mL}$ de células (obtidas do passo 2) foram introduzidos em cada frasco;

7. Os frascos foram tampados com tampa de butila e fechados com rosca plástica;

8. Os frascos receberam $33 \mathrm{~mL}$ de oxigênio puro (100\%), injetados através de seringa;

9. $12 \mathrm{~mL}$ da fase líquida foram sacados de cada reator para as análises de interesse ao ensaio. Os resultados obtidos foram admitidos como correspondentes ao tempo zero de ensaio.

Para cada amostra retirada, foram determinadas as concentrações de nitrato, nitrito e ácidos voláteis (por cromatografia gasosa). Antes da retirada de cada amostra líquida do frasco, media-se a pressão no seu interior; em seguida, a amostra líquida era retirada e a pressão era medida novamente. A pressão inicial era restabelecida através da introdução de gás hélio (100\%) nos frascos.

\subsection{Parâmetros e métodos de análises}

Os principais parâmetros analisados e os respectivos métodos de determinação utilizados estão apresentados na Tabela 14.

As concentrações de nitrogênio amoniacal $\left(\mathrm{N}-\mathrm{NH}_{3}+\mathrm{N}-\mathrm{NH}_{4}{ }^{+}\right)$, nitrato $\left(\mathrm{N}_{-} \mathrm{NO}_{3}{ }^{-}\right)$, nitrito $\left(\mathrm{N}-\mathrm{NO}_{2}{ }^{-}\right), \mathrm{DQO}$, sólidos totais (ST), sólidos totais voláteis (STV), sólidos totais fixos (SST), pH, ácidos voláteis e alcalinidade (total e a bicarbonato) foram determinadas de acordo com técnicas descritas no Standart Methods for Examination of Water and Wastewater (1998).

As concentrações de metanol e de etanol foram determinadas por cromatografia gasosa utilizando cromatógrafo HP 5860 com detector de ionização de chama (FID), através de adaptação na metodologia proposta por Corrêa e Pedroso (1997), descrita por Santos et al. (2002b).

Foi utilizado o método de coloração Gram (DSM, 1991) para verificação de Gram das culturas purificadas a partir dos reatores anóxicos alimentados com metano. 
Tabela 14. Parâmetros analisados e métodos de análises.

\begin{tabular}{|c|c|}
\hline Parâmetro & Método utilizado \\
\hline pH (unidade) & Potenciométrico \\
\hline Alcalinidade $\left(\mathrm{mgCaCo}_{3} \cdot \mathrm{L}^{-1}\right)$ & Titulométrico \\
\hline Ácidos Voláteis (mg HAc . $\mathrm{L}^{-1}$ ) & Titulométrico \\
\hline Ácidos Voláteis (mg . $\left.\mathrm{L}^{-1}\right)$ & Cromatografia líquida \\
\hline DQO total (mg .L $\left.{ }^{-1}\right)$ & Espectrofotométrico \\
\hline DQO solúvel (mg .L ${ }^{-1}$ ) & Espectrofotométrico \\
\hline $\mathrm{N}-\mathrm{NH}_{4}^{+}\left(\mathrm{mgN} . \mathrm{L}^{-1}\right)$ & Titulométrico \\
\hline $\mathrm{N}^{-\mathrm{NO}_{2}}{ }_{2}^{-}\left(\mathrm{mgN} . \mathrm{L}^{-1}\right)$ & Espectrofotométrico \\
\hline $\mathrm{N}-\mathrm{NO}_{3}^{-}\left(\mathrm{mgN} \cdot \mathrm{L}^{-1}\right)$ & Espectrofotométrico \\
\hline $\mathrm{N}-\mathrm{N}_{2} \mathrm{O}(\mathrm{mg}-\mathrm{N} / \mathrm{L})$ & Cromatografia gasosa \\
\hline $\mathrm{ST}\left(\mathrm{mg} \cdot \mathrm{L}^{-1}\right)$ & Gravimétrico \\
\hline $\operatorname{STF}\left(\mathrm{mg} \cdot \mathrm{L}^{-1}\right)$ & Gravimétrico \\
\hline $\mathrm{STV}\left(\mathrm{mg} \cdot \mathrm{L}^{-1}\right)$ & Gravimétrico \\
\hline Composição do Gás (\%) & Cromatografia gasosa \\
\hline Etanol & Cromatografia gasosa \\
\hline Metanol & Cromatografia gasosa \\
\hline
\end{tabular}

$\mathrm{O}$ método de inibição do acetileno $\left(\mathrm{C}_{2} \mathrm{H}_{2}\right)$ à redução enzimática de $\mathrm{N}_{2} \mathrm{O}$ a $\mathrm{N}_{2}$, proposto por Yoshinari e Knowles (1976), foi empregado para verificação da via metabólica utilizada pelos microrganismos, através da observação da produção de $\mathrm{N}_{2} \mathrm{O}$. As amostras de gás foram retiradas da fase gasosa utilizando-se seringas "gastight” (1 $\mathrm{mL}$ ). As concentrações de $\mathrm{N}_{2} \mathrm{O}$ foram calculadas através da integração das áreas dos cromatogramas, utilizando-se curva padrão de acordo com a pureza do gás de 99\%. Foi utilizado cromatógrafo Gow-Mac com coluna Porapak Q, com 2 m de comprimento e diâmetro de 1/4”. O forno operou à temperatura de $25{ }^{\circ} \mathrm{C}$. Como gás de arraste, foi utilizado o hidrogênio. As mesmas condições cromatográficas foram aplicadas para determinação do teor de metano presente no biogás, determinado através da leitura correspondente em curva padrão, especialmente elaborada para cada ensaio.

Os ácidos voláteis, quantificados no ensaio cinético com culturas purificadas (item 5.6.2), foram determinados por cromatografia líquida (HPLC). O sistema Shimadzu para HPLC era constituído por: bomba LC-10AD VP; válvula FCV-10AL; forno CTO-10A VP; detector SPD-M 10A VP (ultra violeta com arranjos de diodos); controlador SCL-10 ${ }^{\mathrm{A}} \mathrm{VP}$; microcomputador LG Pentium 4, equipado com software Shimadzu Clsaa-VP; Coluna Aminex HPx-87H - 300 x 7,8 mm. Solução 0,005 M de 
$\mathrm{H}_{2} \mathrm{SO}_{4}$ foi utilizada como eluente. A velocidade de fluxo foi de $0,5 \mathrm{~mL} / \mathrm{min}$, a temperatura do forno foi igual a $45{ }^{\circ} \mathrm{C}$ e o comprimento de onda $(\lambda)$ igual a $205 \mathrm{~nm}$.

No lodo de inóculo e na fase B do ensaio descrito no item 5.3, foi realizada a quantificação celular, de bactérias desnitrificantes, através da técnica de número mais provável (NMP), de acordo com metodologia descrita por Alexander (1982) para quantificação em amostras de solo, modificada para as condições de água. Todo o material e soluções utilizadas, foram previamente esterilizados, em autoclave. As amostras foram incubadas em ambiente estéril. As seguintes adaptações foram necessárias:

1. Foram preparados 10 tubos de ensaio de $20 \mathrm{~mL}$ (Tubo A), contendo $9 \mathrm{~mL}$ de água de diluição (1 mL de sol $\mathrm{K}_{2} \mathrm{HPO}_{4}$ e 0,25 mL de sol $\mathrm{KH}_{2} \mathrm{PO}_{4}$, em 250mL de água milli-q);

2. Em seguida, 4,5 mL de meio, constituído de água residuária sintética esterilizada por filtração em membrana de $0,22 \mu \mathrm{m}$, foram distribuídos em tubos de DQO (Tubo B);

3. $1 \mathrm{~mL}$ de lodo macerado (provenientes dos reatores anóxicos comparativos) foram inseridos no tubo A. Este tubo representou a diluição $10^{-1}$;

4. $0,5 \mathrm{~mL}$ foram retirados do tubo $\mathrm{A}$, de diluição $10^{-1}$, e introduzidos em cinco tubos $\mathrm{B}$, constituindo cinco réplicas da diluição $10^{-1}$;

5. $1 \mathrm{~mL}$ foi retirado do frasco de diluição $10^{-1}$ (Tubo A) e inserido em outro tubo de ensaio (Tubo $\mathrm{A}_{2}$ ), que continha $9 \mathrm{~mL}$ de água de diluição, e este, constituiu a diluição $10^{-2}$;

6. $0,5 \mathrm{~mL}$ foram retirados do tubo $\mathrm{A}_{2}$, de diluição $10^{-2}$, e introduzidos em cinco tubos $\mathrm{B}$, constituindo cinco réplicas da diluição $10^{-2}$;

7. Este procedimento foi repetido até que a diluição $10^{-10}$ fosse atingida;

8. As amostras (réplicas dos frascos B) foram mantidas em incubadora, sem agitação, à temperatura de $30^{\circ} \mathrm{C} \pm 1{ }^{\circ} \mathrm{C}$.

9. Após 15 dias, todas as amostras foram retiradas da incubadora;

10. Aproximadamente $1 \mathrm{~mL}$ foram retirados de cada frasco e colocados em tubo de ensaio de $5 \mathrm{~mL}$;

11. 2 gotas de difenilamina $\left(\left(\mathrm{C}_{6} \mathrm{H}_{5}\right)_{2} \mathrm{NH}-0,2 \%\right.$ em ácido sulfúrico concentrado) foram introduzidos nos tubos de ensaio de $5 \mathrm{~mL}$; 
12. Os tubos que apresentaram coloração azul escura indicaram haver presença de nitrato ou nitrito, foram, portanto, considerados negativos, de acordo com a metodologia; os tubos com ausência de cor, foram considerados positivos.

Obtida a composição dos tubos positivos, determinou-se o número mais provável, a partir de tabela estatística, apresentada por Alexander (1982).

O acompanhamento das morfologias presentes nos lodos foi realizado através de microscopia óptica comum e de contraste de fase, em microscópio Olympus (BX 60). Também foram realizadas análises de microscopia eletrônica de varredura (MEV) de acordo com a metodologia descrita por Nation (1983) e adaptada por Araújo (1995) para biofilmes.

\subsubsection{Metodologias utilizadas nas análises de Biologia Molecular}

O acompanhamento da diversidade microbiana presente na biomassa dos ensaios de desnitrificação foi realizado através da aplicação de técnicas de Biologia Molecular, que compreenderam as seguintes etapas: extração de DNA do lodo, amplificação dos fragmentos de DNA, por PCR, e análise da diversidade microbiana, por DGGE. As amostras de lodo, retiradas dos reatores RE, RM1 e RM2, foram armazenadas em freezer $\left(\sim-20^{\circ} \mathrm{C}\right)$ por, aproximadamente 1 ano e meio, enquanto as amostras dos reatores $\mathrm{M}, \mathrm{MO}, \mathrm{MM}$, MMO e $\mathrm{C}$ foram armazenadas por seis meses.

Foi realizada extração de DNA das culturas purificadas $\mathrm{MMO}_{3}$ e $\mathrm{MMO}_{2}$ (descritas no item 5.6.1). Tais amostras foram amplificadas, por PCR, com primer para o domínio Bacteria.

\subsubsection{Extração de DNA}

A extração de DNA das amostras de lodo, coletadas aos longo da operação dos reatores anóxicos, foi realizada de acordo com protocolo apresentado por Melvin e Hobson (1994), o qual encontra-se descrito a seguir, com algumas adaptações que se fizeram necessárias para adequação deste protocolo aos equipamentos disponíveis:

1. Aproximadamente $7 \mathrm{~mL}$ de lodo foram centrifugados $(6.000 \mathrm{rpm}$, por 4 minutos) em tudo Falcon de polipropileno $(15 \mathrm{~mL})$ e o sobrenadante foi descartado;

2. $0,5 \mathrm{~g}$ de lodo úmido foi pesado diretamente em tubo Falcon $(15 \mathrm{~mL})$; 
3. Adicionaram-se $3 \mathrm{~mL}$ de PBS (8 g/L de NaCl; 0,2 g/L de KCl; 0,24 g/L de $\mathrm{KH}_{2} \mathrm{PO}_{4} ; 1,44 \mathrm{~g} / \mathrm{L}$ de $\left.\mathrm{Na}_{2} \mathrm{HPO}_{4}, \mathrm{pH} 7,4\right)$ ao tubo e macerou-se o lodo, com o auxílio de ponteira plástica de $10 \mathrm{~mL}$ com a extremidade fechada em Bico de Bunsen;

4. A amostra foi centrifugada a 6.000 rpm por 4 minutos;

5. O sobrenadante foi descartado e o precipitado foi ressuspendido em 1,0 mL de tampão TESC (Tris 10 mM; EDTA 1 mM; NaCl 0,1mMpH 8,3);

6. A amostra foi congelada a $-80^{\circ} \mathrm{C}$, por 5 minutos;

7. A amostra foi descongelada e centrifugada (6.000 rpm, por 2 minutos) e o sobrenadante descartado;

8. O pellet foi ressuspendido em $300 \mu \mathrm{L}$ de tampão TESC (10 mM de Tris; 1 mM de EDTA; 0,1 mM de $\mathrm{NaCl}, \mathrm{pH}$ 8,3);

9. $5 \mu \mathrm{L}$ de DMSO foram adicionados a esse volume;

10. A amostra foi mantida por 1 minuto à temperatura ambiente;

11. A amostra foi homogeneizada em vórtex, por 3 minutos;

12. Os seguintes reagentes foram adicionados na seguinte ordem:

a. $500 \mu \mathrm{L}$ de guanidina tiocianato $5 \mathrm{M}$;

b. $500 \mu \mathrm{L}$ de clorofórmio:álcool isoamílico (24:1 v/v)

13. A amostra foi homogeneizada em vórtex e centrifugada a $6.000 \mathrm{rpm}$, por 10 minutos;

14. A fase aquosa $( \pm 1000 \mu \mathrm{L})$ foi transferida para tubo "eppendorf“de $1,5 \mathrm{~mL}$;

15. Adicionaram-se 50\% do volume da fase aquosa de acetato de amônio 7,5 M;

16. O tubo "eppendorf" foi misturado levemente e o volume de amostra foi dividido igualmente em 3 tubos;

17. O DNA foi precipitado com a adição de 2 vezes o volume de amostra, de etanol absoluto gelado e agitou-se levemente;

18. As amostras foram centrifugadas (6.000 rpm, por 10 minutos) e o sobrenadante, descartado;

19. As amostras de DNA foram lavadas com $500 \mu \mathrm{L}$ de etanol 70\%, invertendose o tubo várias vezes;

20. As amostras foram centrifugadas (6.000 rpm, por 3 minutos) e o sobrenadante descartado, com cuidado; 
21. As amostras foram deixadas à temperatura ambiente para evaporação da água (aprox. 15 minutos);

22. Os pellets de DNA foram ressuspendidos em $50 \mu \mathrm{L}$ de tampão TE (10 mM de Tris; 1 mM de EDTA, pH 8,3);

23. As amostras de DNA obtidas foram mantidas em freezer $\left(-20^{\circ} \mathrm{C}\right)$.

O produto da extração de DNA foi avaliado em gel de agarose 1,0\%, corado com Brometo de Etídeo (0,5 mg/L) por 10 minutos, sendo o excesso do Brometo de Etídeo retirado através de lavagem do gel em água milli-q por 5 minutos. Os géis foram observados em sistema de ultra-violeta Eagle Eye TMIII (Stratagene), acoplado a microcomputador e Software Eagle Sight. Como marcador foi utilizado $\lambda$ Hind III fragment.

Todas as amostras de DNA foram purificadas através da utilização do kit de purificação Wizard DNA Clean-Up System (Promega), seguindo protocolo descrito pelo fabricante do kit.

\subsubsection{Amplificação por PCR}

Com o DNA extraído do material biológico, foram amplificados fragmentos do gene de DNAr 16S, dos Domínios Bacteria e Archaea, utilizando-se a técnica do PCR com primers homólogos a regiões conservadas do gene RNAr 16S. Os primers usados para os Domínios Bacteria e Archaea foram os descritos por Nielsen et al. (1999) e por Kudo et al. (1997), respectivamente, apresentados na Tabela 15.

Tabela 15. Seqüências dos primers utilizados para amplificação dos fragmentos de DNA.

\begin{tabular}{llc}
\hline Domínio / Primer & Seqüência (sentido 5’ $\rightarrow$ 3’) \\
\hline \multirow{5}{*}{ Bacteria } & $968 \mathrm{f} \mathrm{GC}$ & AAC GCG AAG AAC CTT AC \\
& $1392 \mathrm{r}$ & ACG GGC GGT GTG TAC \\
& GC Clamp* & CGC CCG GGG CGC GCC CCG GGC GGG GCG GGG GCA \\
& $1100 \mathrm{f} \mathrm{GC}$ & CGG GGGG \\
Archaea & AAC CGT CGA CAG TCA GGY AAC GAG CGAG \\
& GC Clamp* & CGC CCG CCG CGC GCGGCG GGC GGG GCG GGG GCA \\
& & CGG GGG G \\
\hline
\end{tabular}

* - a seqüência GC Clamp está ligada aos primers forward.

Como controle positivo para o domínio Bacteria foi utilizada cultura de microrganismos purificada a partir do reator MMO, através da técnica de diluições 
decimais seriadas, purificadas na presença de nitrato $-\mathrm{MMO}_{3}(\mathrm{CP} 1$ - controle positivo 1) e na presença de nitrito - $\mathrm{MMO}_{2}$ (CP2 - controle positivo 2). Para o domínio Archaea foi utilizada cultura de arquea metanogênica (bacilos fluorescentes), cedida pelo pesquisador Gilson Paulo Manfio da Universidade Estadual de Campinas (UNICAMP). As amostras utilizadas como controle positivo para o domínio Bacteria foram as utilizadas como controle negativo para o domínio Archaea e vice-versa.

O volume total da reação de PCR foi de $50 \mu l$, com composição apresentada na Tabela 16. As condições de amplificação são apresentadas, para cada Domínio, na Tabela 17.

Tabela 16. Composição da reação de PCR

\begin{tabular}{cc}
\hline Reagente & Volume $(\mu \mathrm{L} / 50 \mu \mathrm{L}$ de reação) \\
\hline Água milli-q estéril & 35,0 \\
Tampão PCR 10 x & 5,0 \\
Solução MgCl $(50 \mathrm{mM})$ & 1,5 \\
dNTP (2 mM) & 5,0 \\
primer forward (100 pmol) & 0,5 \\
primer reverse (100 pmol) & \\
(Bacteria - 968f GC ou Archaea - 1100f GC) & 0,5 \\
(Bacteria - 1392r ou Archaea - 1400r) & 0,5 \\
Taq DNA Polimerase (5 U/ $\mu \mathrm{L})$ & 2,0 \\
Template (20-100 ng) &
\end{tabular}

Tabela 17. Temperatura e duração das etapas da amplificação por PCR

\begin{tabular}{|c|c|c|c|c|}
\hline \multirow[t]{2}{*}{ Etapa } & \multicolumn{2}{|c|}{$\begin{array}{c}\text { Domínio Bacteria } \\
\text { (NIELSEN et al., 1999) }\end{array}$} & \multicolumn{2}{|c|}{$\begin{array}{c}\text { Domínio Archaea } \\
\text { (OYAIZU et al., 2000). }\end{array}$} \\
\hline & Temperatura $\left({ }^{\circ} \mathrm{C}\right)$ & Duração & Temperatura $\left({ }^{\circ} \mathrm{C}\right)$ & Duração \\
\hline Pré-desnaturação & 94 & 5 min. & 94 & 90 seg. \\
\hline Desnaturação & 94 & $45 \mathrm{seg}$. & 94 & $30 \mathrm{seg}$. \\
\hline 35 ciclos Anelamento & 38 & $45 \mathrm{seg}$. & 55 & $30 \mathrm{seg}$. \\
\hline Extensão & 72 & $1 \mathrm{~min}$. & 72 & $90 \mathrm{seg}$. \\
\hline Final da extensão & 72 & $5 \mathrm{~min}$. & 72 & $3 \mathrm{~min}$. \\
\hline
\end{tabular}

As amplificações foram realizadas em termociclador "Gene Amp PCR System 2400” (Perkin-Elmer Cetus, Norwalk, Conn.). A qualidade do produto obtido no PCR foi confirmada em gel de agarose $1,2 \%$, sendo que as etapas para observação do gel foram as mesmas utilizadas para verificação do produto da extração de DNA. Como marcador foi utilizado $\phi \mathrm{K} 174$ HAE III disgest. 


\subsubsection{Eletroforese em gel de gradiente desnaturante (DGGE)}

Para separação dos fragmentos amplificados de DNA foi utilizado o sistema DGGE-D Code ${ }^{T M}$ - Universal Mutation Detection System (Bio-Rad, Inc., Hercules, Califórnia), com gradiente de desnaturação do gel de 35\% a 55\%, tanto para separação dos fragmentos de DNA do domínio Bacteria, como para os do domínio Achaea. O protocolo utilizado, apresentado por Sakamoto (2001), encontra-se descrito a seguir acrescido das modificações necessárias às adaptações dos equipamentos disponíveis:

1. Foram preparadas as soluções do gel nas concentrações de $0 \%$, 35\% e 55\%, de acordo com a Tabela 18, através da dissolução da uréia nos reagentes líquidos e completando o volume até 100mL com água milli-q;

Tabela 18. Composição da solução do gel gradiente desnaturante.

\begin{tabular}{cccc}
\hline \multirow{2}{*}{ Reagentes } & \multicolumn{3}{c}{ Concentração desejada do gel } \\
\cline { 2 - 4 } & $0 \%$ & $35 \%$ & $55 \%$ \\
\hline 40\% de gel de acrilamida (mL) & 20 & 20 & 20 \\
Solução de TAE 50 X (mL) & 2 & 2 & 2 \\
Formamida (mL) & 0 & 14 & 22 \\
Uréia (g) & 0 & 14,7 & 23,1 \\
\hline
\end{tabular}

2. Montou-se o kit de "sanduíche”de placas de vidro e suporte;

3. Os três géis a serem introduzidos nas placas de vidro foram preparados, utilizando-se as soluções dos géis (Tabela 18), do seguinte modo:

- em tubos* de centrífuga de $15 \mathrm{~mL}$, adicionou-se $14 \mathrm{~mL}$ da solução de 55\%, $100 \mu \mathrm{L}$ de $10 \%$ APS e $10 \mu \mathrm{L}$ de temed**.

- em tubos* de centrífuga de $15 \mathrm{~mL}$, adicionou-se $14 \mathrm{~mL}$ da solução de 35\%; $100 \mu \mathrm{l}$ de $10 \%$ APS; e $10 \mu \mathrm{l}$ de temed**.

- em *tubos de centrífuga de 15 mL, adicionou-se $3 \mathrm{~mL}$ da solução de $0 \%$; 20 $\mu \mathrm{l}$ de $10 \%$ APS; e $2 \mu \mathrm{l}$ de temed**.

Obs: $\quad$ *Os tubos de centrífuga contendo as soluções, foram mantidos em gelo, durante a preparação dos géis.

**O temed foi adicionado por último, pois este reagente provocava a solidificação do gel. Por isso, depois de sua adição o gel foi usado imediatamente.

4. Os géis (35\% e 55\%) foram transferidos simultaneamente para o "sanduíche" de placas de vidro, com auxílio de duas seringas presas ao aparelho injetor; 
5. Após 10 minutos, colocou-se uma placa semelhante a um pente, para formar os poços. Em seguida, adicionou-se a solução do gel 0\%;

6. Aguardou-se 1 hora para os géis solidificarem;

7. A “câmara eletroforética” foi preparadas através da adição de $140 \mathrm{~mL}$ de TAE $50 \mathrm{X}$, completando o volume de 7 litros, com água Milli-q, o que resultou em solução TAE $1 \mathrm{X}$;

8. Colocou-se a solução para aquecer à temperatura de $65{ }^{\circ} \mathrm{C}$, sendo que a temperatura de “corrida” foi de $60{ }^{\circ} \mathrm{C}$;

9. Quando a temperatura da "câmara eletroforética” atingiu os $65{ }^{0} \mathrm{C}$; transferiu-se o "sanduíche” para seu interior;

10. O "pente" foi retirado e os poços formados foram lavados com a solução tampão (TAE 1 X), utilizando-se micropipeta;

11. Preparou-se as amostras, misturando-se $20 \mu \mathrm{L}$ de amostra ("template”) com $5 \mu \mathrm{L}$ de 6 x loading dye;

12. Transferiu-se a mistura (amostra+corante) para os poços do gel;

13. A bomba de agitação de foi ligada e eletrodos conectados à voltagem de $130 \mathrm{~V}$;

14. O tempo de “corrida”foi igual a 6h (360 minutos);

15. Transferiu-se o gel das placas de vidro para corar em solução de Brometo de Etídeo (0,5 mg/L) por 15 minutos.

16. O excesso de Brometo de Etídeo foi retirado através da lavagem do gel em água milli-q por 10 minutos.

17. A leitura do gel foi realizada em sistema de ultra-violeta Eagle Eye TMIII (Stratagene), acoplado a microcomputador e Software Eagle Sight.

\subsection{Análise dos resultados obtidos nos ensaios cinéticos}

A análise dos resultados obtidos foi feita através de ajuste de modelo cinético aos perfis temporais de concentração de nitrato e nitrito. Os resultados são apresentados na forma de gráficos, obtidos através dos programas computacionais Microsoft Excel e Microcal Origin 6.0. Com o auxílio destes programas, os parâmetros cinéticos foram obtidos e utilizados como ferramenta de comparação entre os doadores de elétrons para desnitrificação e análise dos resultados. 


\section{RESULTADOS E DISCUSSÃO}

Neste capítulo, os resultados estão apresentados e discutidos na mesma seqüência em que foram descritos no capítulo 5.

\subsection{Experimentos com reatores anóxicos comparativos}

\subsubsection{Relação $C / N=1,5$}

Nos primeiros cinco dias de operação, a concentração de nitrogênio amoniacal, presente no efluente dos reatores (Figuras 13; 14 e 15), foi consideravelmente maior que a concentração no afluente. Por este motivo, a relação $\mathrm{C} / \mathrm{N}$ foi diminuída para 1,0, no sexto dia de operação, devido à possibilidade de estar ocorrendo o processo de redução dissimilativa de nitrato a amônia (RDNA), em substituição à desnitrificação. Uma causa provável para a prevalência da RDNA poderia ser a elevada relação C/N.

Com a continuidade da operação desses reatores, observou-se que a concentração de nitrogênio amoniacal efluente diminuiu com o tempo, até manter-se pouco superior à do afluente (Figuras 13, 14 e 15), mesmo após alguns meses de operação.

Como o lodo de inóculo era predominantemente metanogênico e foi armazenado em geladeira, é provável que tenha ocorrido, inicialmente, a autólise da massa celular inativa presente nos reatores; ou seja, fração substancial do lodo biológico nos reatores, impossibilitada de operar como lodo desnitrificante, estaria submetida a intenso processo de respiração endógena, que libera constituintes do citoplasma para o meio.

\subsubsection{Relação $C / N=1$ (Fases $A$ e B)}

As Figuras 13, 14 e 15 apresentam os dados de monitoramento para nitrato, nitrito e N-amoniacal, durante os primeiros quatro meses de operação dos reatores desnitrificantes, alimentados com etanol (RE), metanol (RM1) e metano (RM2), respectivamente. 
No sexto dia de operação, a relação C/N foi diminuída para 1,0, em RE e RM1, não tendo sido detectada qualquer alteração significativa nos valores dos parâmetros de monitoramento.

É possível observar que, desde o início da operação, os reatores RE e RM1 apresentaram eficiências de remoção de nitrato em torno de 98\%, chegando a 100\%, na maior parte do tempo. Por outro lado, observa-se (Figura 14) que o reator alimentado com metano demorou aproximadamente 3 meses para alcançar a estabilidade operacional, tendo sido alcançada eficiência média de remoção de nitrato de $87 \%$ após esse período.

Os ensaios para determinação dos parâmetros cinéticos intrínsecos, apresentados no item 6.2, mostraram que, apesar de a concentração de nitrogênio amoniacal no efluente de todos os reatores (5,0 $\mathrm{mg} \mathrm{N}-\mathrm{NH}_{4}{ }^{+} / \mathrm{L}$, para RE e 8,0 $\mathrm{mg} \mathrm{N}-\mathrm{NH}_{4}{ }^{+} / \mathrm{L}$ para RM1 e RM2) ter se mantido superior à do afluente $\left(\sim 4,0\right.$ mg-N-NH$\left.{ }_{4}^{+} / \mathrm{L}\right)$, ao longo de todo o tempo de operação, a desnitrificação foi confirmada através da produção de $\mathrm{N}_{2} \mathrm{O}$. A presença deste composto intermediário, que foi quantificado neste ensaio, pois sua produção antecede a etapa final da desnitrificação, constitui-se em importante indicativo de sua ocorrência. Além disso, o acompanhamento das morfologias presentes na biomassa, através da microscopia, ao longo do experimento, permitiu constatar intenso processo de seleção dos microrganismos nos reatores. Observou-se, também, em todos os reatores, entre a fase inicial (inoculação) e a fase $B$, o desenvolvimento de microrganismos pertencentes ao domínio Bacteria (Figura 27).

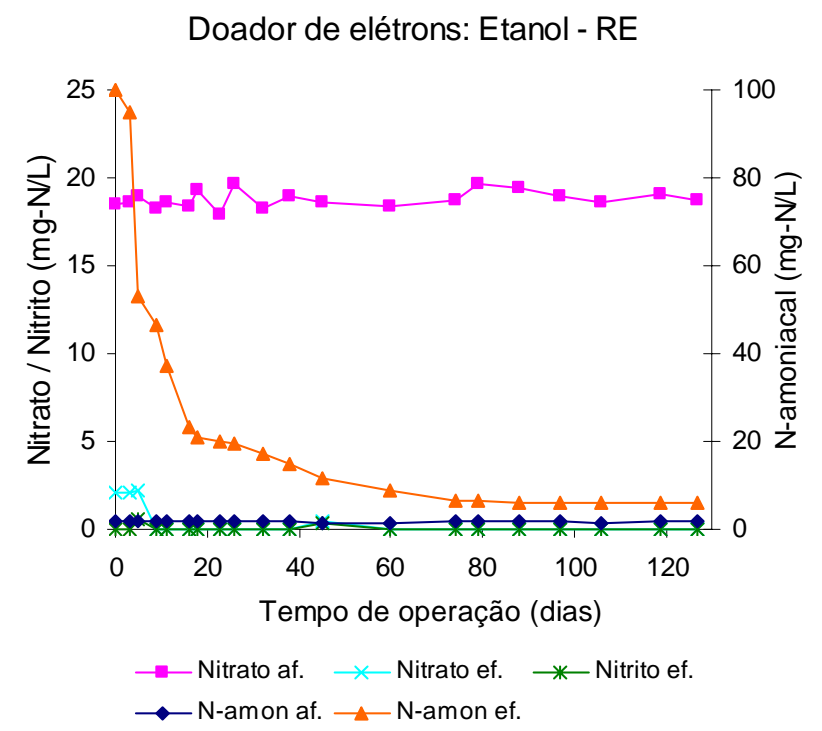

Figura 12. Resultados do monitoramento do reator alimentado com etanol (RE) para $C / N=1,0$. 


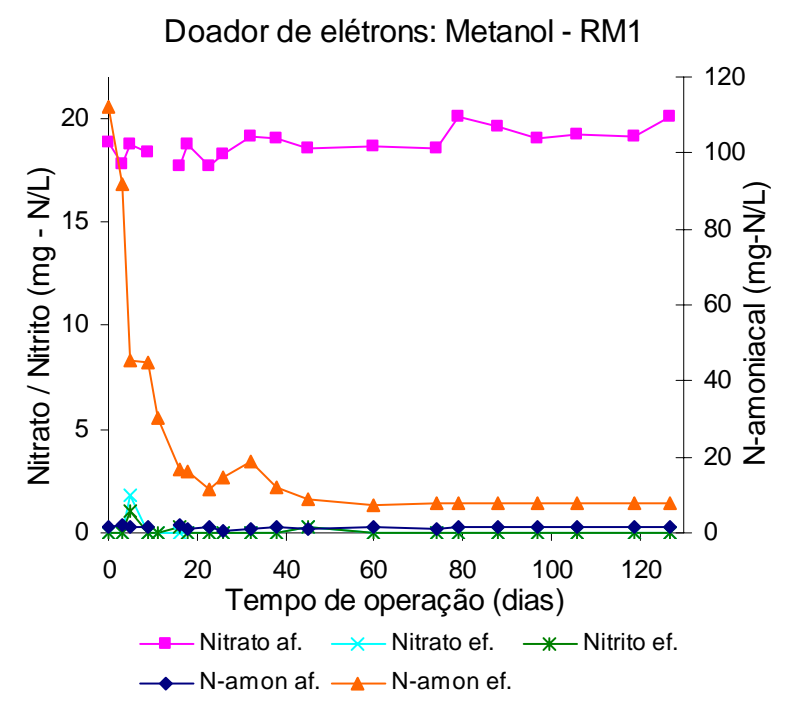

Figura 13. Resultados do monitoramento do reator alimentado com metanol (RM1) para $C / N=1,0$.

Doador de elétrons: Metano - RM2

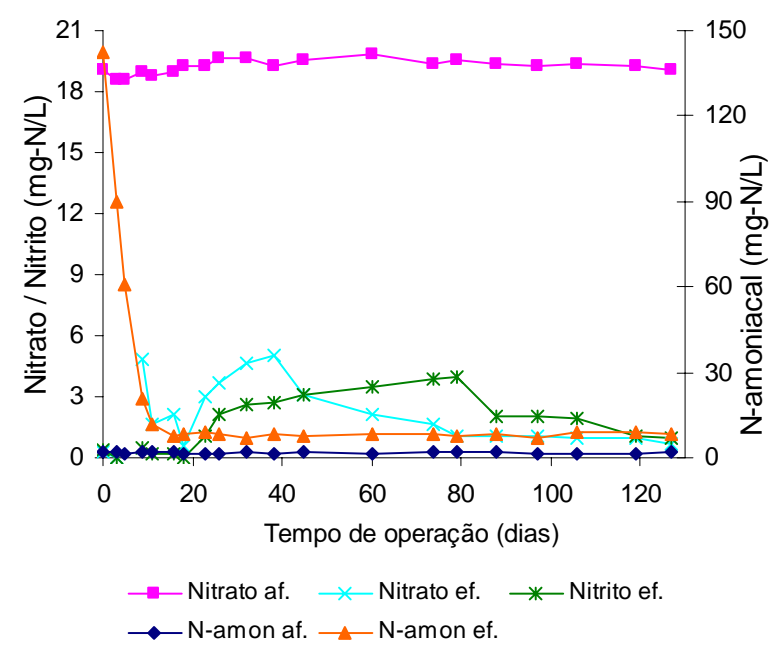

Figura 14. Resultados do monitoramento do reator alimentado com metano/ar (50\%/50\%) - (RM2).

Os resultados dos parâmetros de monitoramento $\mathrm{pH}$, alcalinidade a bicarbonato e ácidos voláteis, presentes no efluente dos reatores, encontram-se resumidos na Tabela 19, na qual são apresentados os valores mínimos, médios e máximos obtidos. Apresentam-se, apenas, os resultados de alcalinidade a bicarbonato, omitindo-se outras formas de alcalinidade, pelo fato de ser a única produzida durante o processo de desnitrificação.

Os valores médios de $\mathrm{pH}$, alcalinidade a bicarbonato e ácidos voláteis, afluentes aos reatores, foram iguais a 7,4 \pm 0,1; $53 \mathrm{mg} \mathrm{CaCO}_{3} / \mathrm{L} \pm 6 \mathrm{mg} \mathrm{CaCO}_{3} / \mathrm{L}$ e $29 \mathrm{mg}$ ác. acético/L \pm 4 mg ác. acético/L, respectivamente. Nenhum desses parâmetros apresentou variação significativa ao longo do período de operação dos reatores RE e RM1. Apenas no início da operação é que foram observados valores mais elevados da alcalinidade a 
bicarbonato (em torno de $200 \mathrm{mg} / \mathrm{L}$, medidos como $\mathrm{CaCO}_{3}$ ), provavelmente decorrente da geração de N-amoniacal nos primeiros cinco dias de operação.

Para o reator RM2, os valores de pH e de ácidos voláteis não apresentaram grandes variações $(7,4 \pm 0,1$ e $40 \mathrm{mg}$ ác. acético/L $\pm 7 \mathrm{mg}$ ac. acético/L, respectivamente). No entanto, os valores de alcalinidade a bicarbonato apresentaram flutuação considerável, sendo que os maiores valores foram observados nos primeiros três meses (129 mg $\left.\mathrm{CaCO}_{3} / \mathrm{L}\right)$, enquanto que valores próximos ao mínimo foram observados no último mês de operação (73 mg $\left.\mathrm{CaCO}_{3} / \mathrm{L}\right)$.

Tabela 19. Resumo dos resultados obtidos no monitoramento dos reatores.

\begin{tabular}{|c|c|c|c|c|c|c|c|c|c|}
\hline \multirow{3}{*}{ Parâmetro } & \multicolumn{9}{|c|}{ Reator } \\
\hline & \multicolumn{3}{|c|}{$\mathrm{RE}(\mathrm{C} / \mathrm{N}=1,0)$} & \multicolumn{3}{|c|}{$\mathrm{RM} 1(\mathrm{C} / \mathrm{N}=1,0)$} & \multicolumn{3}{|c|}{ RM2 (50\% $\left.\mathrm{CH}_{4} / 50 \% a r\right)$} \\
\hline & Min. & Médio & Máx. & Min. & Médio & Máx. & Min. & Médio & Máx. \\
\hline $\mathrm{pH}$ & 7,0 & $7,2 \pm 0,2$ & 7,5 & 7,0 & $7,2 \pm 0,3$ & 7,7 & 7,3 & $7,4 \pm 0,1$ & 8,1 \\
\hline Alcalinidade total a & & & & & & & & & \\
\hline $\begin{array}{l}\text { bicarbonato } \\
\left(\mathrm{mg} \mathrm{CaCO}_{3} / \mathrm{L}\right)\end{array}$ & 139 & $183 \pm 51$ & 224 & 121 & $168 \pm 37$ & 203 & 65 & $125 \pm 30$ & 156 \\
\hline $\begin{array}{l}\text { Ácidos voláteis } \\
\text { (mg Ác. Acético/L) }\end{array}$ & 33 & $36 \pm 6$ & 43 & 31 & $35 \pm 5$ & 41 & 32 & $40 \pm 7$ & 51 \\
\hline
\end{tabular}

Observa-se que todos os reatores mantiveram uma concentração praticamente constante de ácidos no efluente de cada batelada. É possível atribuir tal concentração ao contínuo processo de hidrólise de material celular que aconteceu em todos os reatores.

A Figura 15 mostra o ajuste do modelo cinético aos dados experimentais, para consumo de nitrato e nitrito, nas fases A (sistema não adaptado) e B (sistema adaptado) para RE, RM1 e RM2. Os perfis temporais de concentração de nitrato e nitrito foram obtidos em duas etapas experimentais: após 60 dias de operação (fase A) e após 120 dias de operação (fase B). Os dados experimentais foram analisados e foi proposto o modelo de reações múltiplas em série, irreversíveis (LEVENSPIEL, 1999), considerando o nitrito como único produto intermediário formado durante a desnitrificação (seq. 4).

$$
\mathrm{NO}_{3}{ }^{-} \stackrel{\mathrm{k}_{1}}{\longrightarrow} \mathrm{NO}_{2}^{-} \stackrel{\mathrm{k}_{2}}{\longrightarrow} \mathrm{N}_{2}
$$

O modelo, considerando-se reação de primeira ordem para o consumo de nitrato e de ordem zero para o consumo de nitrito, foi o que melhor representou os dados experimentais, em RE e RM1. Dessa forma, a partir de balanço de massa em reator 
operado em batelada, os perfis de concentração de nitrato e nitrito puderam ser representados por:

$$
\begin{aligned}
& -\frac{\mathrm{dC}_{\mathrm{NO}_{3}^{-}}}{\mathrm{dt}}=\mathrm{k}_{1} \mathrm{C}_{\mathrm{NO}_{3}^{-}} \\
& \frac{\mathrm{dC}_{\mathrm{NO}_{2}^{-}}}{\mathrm{dt}}=\mathrm{k}_{1} \mathrm{C}_{\mathrm{NO}_{3}^{-}}-\mathrm{k}_{2} \\
& C_{\mathrm{NO}_{3}^{-}}=C_{\mathrm{NO}_{3}^{-}{ }^{-}} \cdot e^{-k_{1} \mathrm{t}} \\
& C_{\mathrm{NO}_{2}^{-}}=C_{\mathrm{NO}_{2}^{-}{ }^{-}} \cdot\left(1-e^{-k 1 t}\right)-k_{2} t
\end{aligned}
$$

Esses resultados diferenciam-se dos obtidos por Bilanovic et al. (1999). Esses autores observaram que a cinética da desnitrificação, na presença de metanol, ocorreu segundo reação de ordem zero, considerando apenas o consumo de nitrato. No experimento relatado, os autores utilizaram reator operado em batelada, alimentado com solução contendo elevadas concentrações de nitrato (500 mg/l) e de metanol (1250 $\mathrm{mg} / \mathrm{l})$.

O modelo cinético anteriormente descrito foi aplicado, também, para o reator alimentado com metano como única fonte externa de carbono (RM2). No entanto, não foi possível obter ajuste razoável, principalmente aos dados de nitrito. Por esse motivo, foi proposto um modelo mais simples, de conversão de nitrato diretamente a $\mathrm{N}_{2}$, obtendo-se ajuste do modelo de ordem zero, segundo o qual o consumo de nitrato pode ser expresso por:

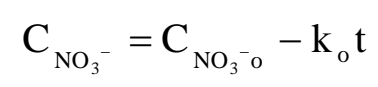

Nas equações (5), (6), (7), (8) e (9) $C_{\mathrm{NO}_{3}^{-}}$é concentração de nitrato, (mg N-NO${ }_{3}^{-}$ /L); $C_{\mathrm{NO}_{2}^{-}}$, a concentração de nitrito $\left(\mathrm{mg} \mathrm{N}-\mathrm{NO}_{2}^{-} / \mathrm{L}\right) ; \mathrm{k}_{1}$, a constante de reação de primeira ordem de conversão de nitrato a nitrito; $k_{2}$, a constante de reação de ordem zero para conversão de nitrito a $\mathrm{N}_{2}$ e $\mathrm{k}_{0}$, a constante de reação de ordem zero para conversão de nitrato a $\mathrm{N}_{2}$, quando o doador de elétrons foi o metano. $\mathrm{O}$ índice (o) subscrito indica a concentração inicial dos aceptores de elétrons. Essas equações foram utilizadas para representar os dados experimentais de nitrato e de nitrito que se encontram apresentados na Figura 15. 

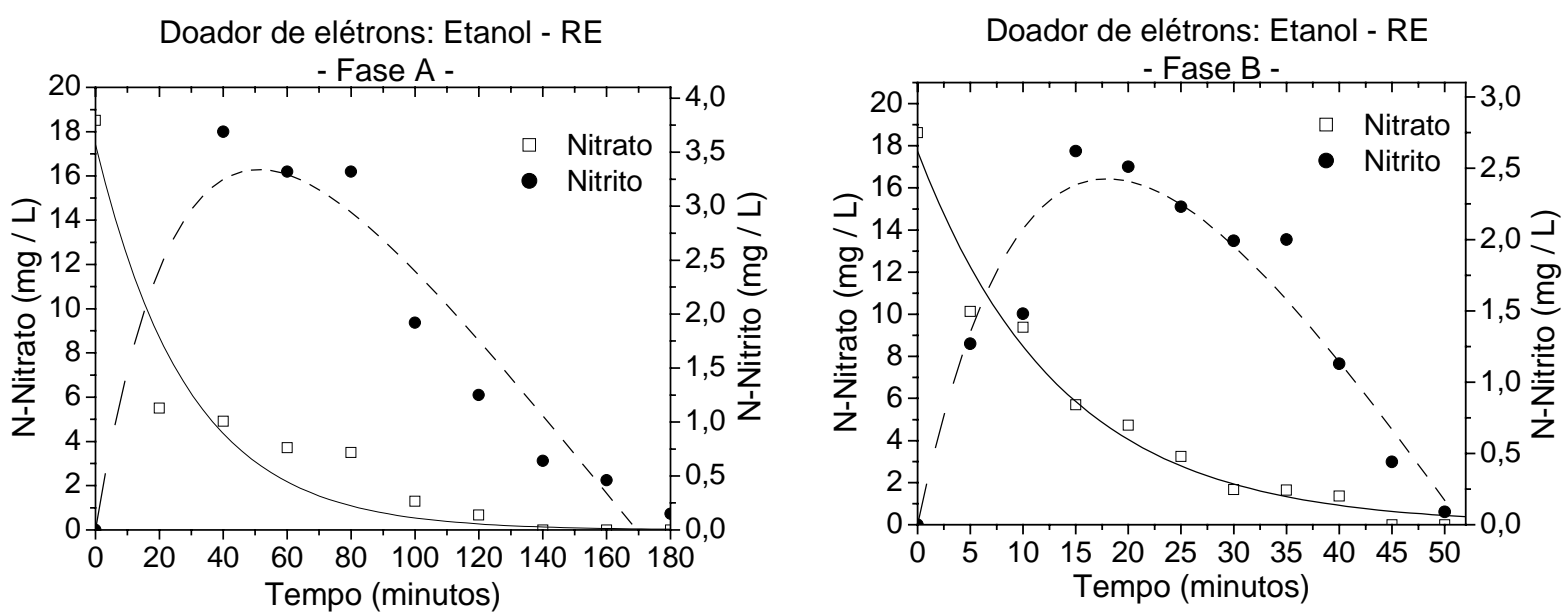

(a)
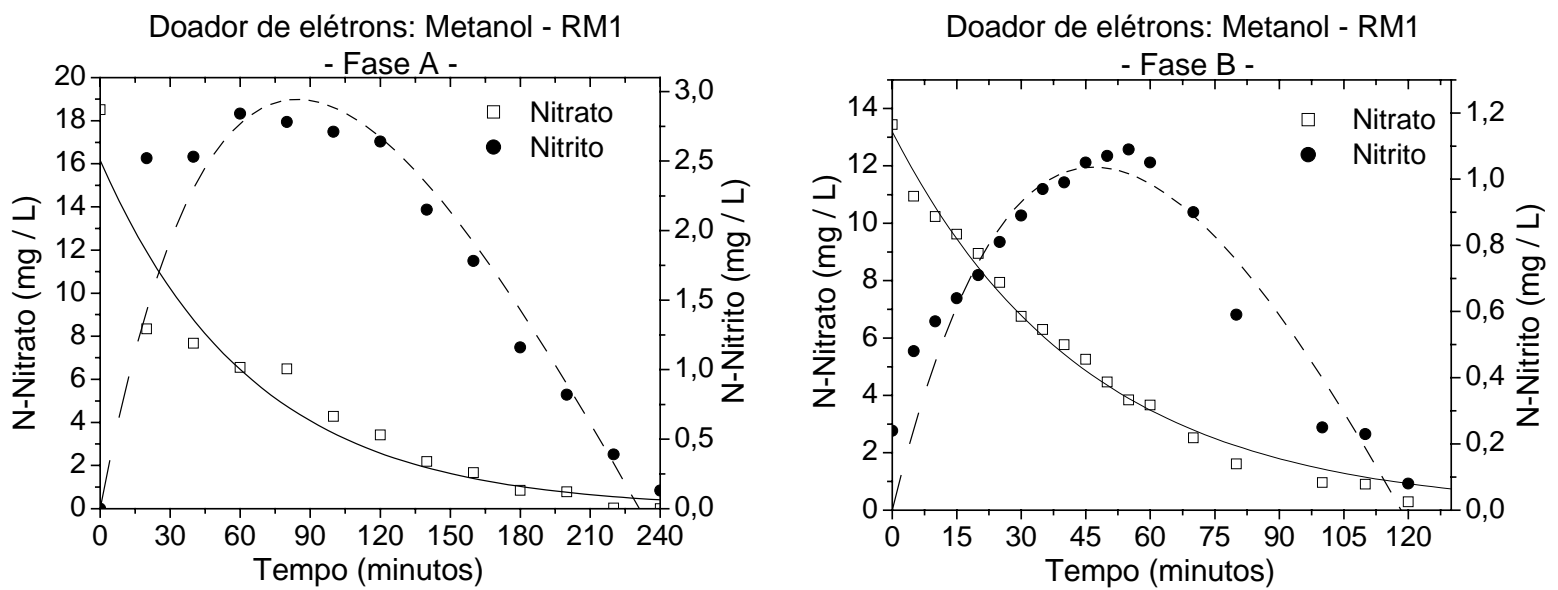

(b)

Doador de elétrons: Metano - RM2
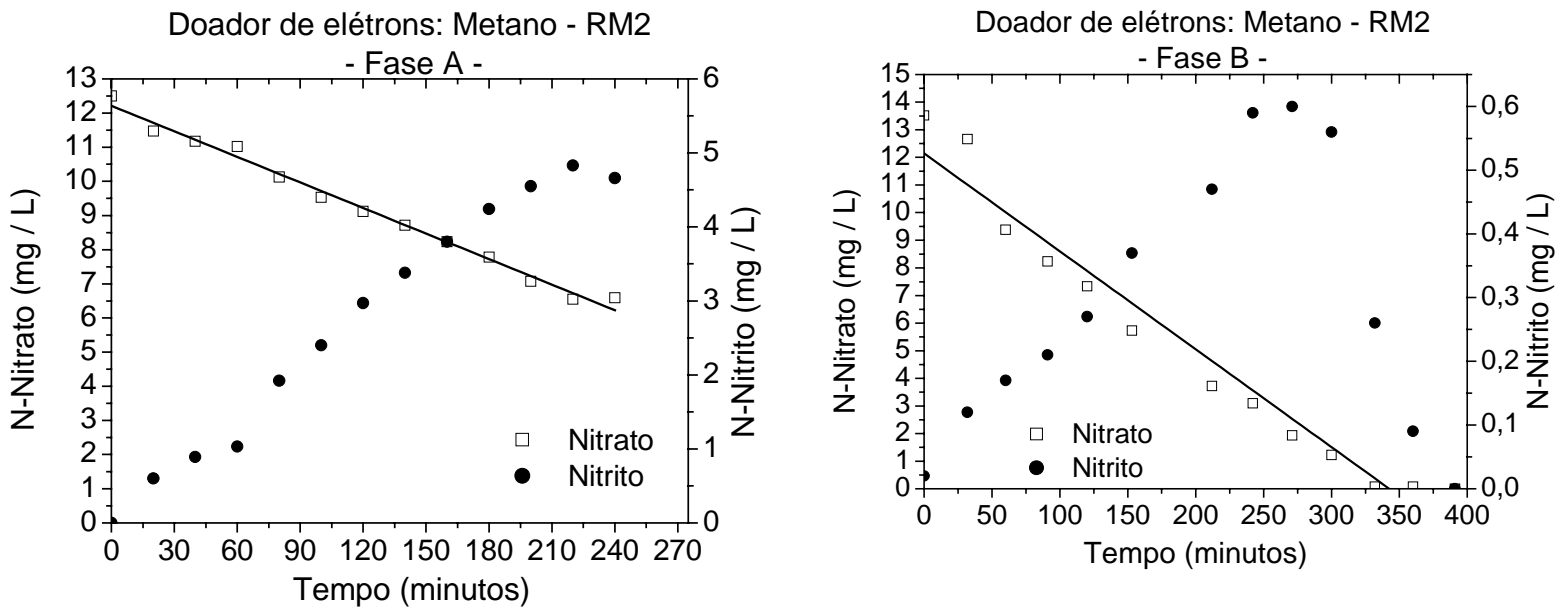

(c)

$\square \quad$ Dados experimentais (nitrato)

Dados experimentais (nitrito)

Modelo cinético (Eq. 9)

Modelo cinético (Eq. 10) Modelo cinético (Eq. 11)

Figura 15. Perfis de concentração de nitrato e nitrito, nas fases de adaptação $(A)$ e de biomassa adaptada (B) para os diferentes doadores de elétrons: (a) Etanol - RE (C/N = 1,0); (b) Metanol RM1 (C/N = 1,0) e (c) Metano - RM2 (50\% $\mathrm{CH}_{4} / 50 \%$ ar). 
Na Tabela 20 são apresentados os parâmetros cinéticos obtidos, nas duas fases experimentais, para os reatores RE e RM1, enquanto que a Tabela 21 apresenta os parâmetros obtidos para RM2.

Os sistemas foram considerados adaptados quando as concentrações de nitrato, nitrito e nitrogênio amoniacal não apresentaram variações significativas de uma batelada para outra. A estabilização ocorreu após quatro meses de operação, aproximadamente, para todos os reatores.

Tabela 20. Parâmetros cinéticos obtidos para modelo de reação em série de primeira ordem seguida de ordem zero para RE e RM1.

\begin{tabular}{ccccc}
\hline \multirow{2}{*}{ Parâmetros cinéticos aparentes } & \multicolumn{4}{c}{ Doador de elétrons } \\
\cline { 2 - 5 } & \multicolumn{2}{c}{ Etanol - RE } & \multicolumn{2}{c}{ Metanol - RM1 } \\
\cline { 2 - 5 } $\mathrm{k}_{1}\left(\mathrm{~h}^{-1}\right)$ & $2,08 \pm 0,36$ & $4,43 \pm 0,32$ & $0,918 \pm 0,12$ & $1,33 \pm 0,05$ \\
$\mathrm{k}_{2}(\mathrm{mg} / \mathrm{L} . \mathrm{h})$ & $2,23 \pm 0,24$ & $6,63 \pm 0,61$ & $2,00 \pm 0,17$ & $1,75 \pm 0,11$ \\
$\mathrm{R}^{2}$ para primeira ordem & 0,926 & 0,978 & 0,922 & 0,989 \\
$\mathrm{R}^{2}$ para ordem zero & 0,925 & 0,924 & 0,886 & 0,887 \\
\hline
\end{tabular}

Tabela 21. Parâmetros cinéticos obtidos para modelo de reação de ordem zero para RM2.

\begin{tabular}{ccc}
\hline \multirow{2}{*}{ Parâmetros cinéticos aparentes } & \multicolumn{2}{c}{ Doador de elétrons: Metano - } \\
\cline { 2 - 3 } & Fase A & Fase B \\
\hline $\mathrm{k}_{\mathrm{o}}(\mathrm{mg} / \mathrm{L} . \mathrm{h})$ & $1,50 \pm 0,05$ & $2,37 \pm 0,002$ \\
$\mathrm{R}^{2}$ & 0,985 & 0,972 \\
\hline
\end{tabular}

Os resultados obtidos em RE e RM1 mostram que o desempenho da biomassa melhorou ao longo do tempo. Ou seja, o processo de adaptação da biomassa às condições nutricionais teve, como resultado, o aumento da velocidade de desnitrificação nos dois casos estudados. Houve redução significativa no tempo necessário para a desnitrificação nesses reatores, após adaptação da biomassa (de 180 min. para 50 min. RE e de 240min. para 130min - RM1). No caso do reator RE, a constante cinética de primeira ordem $\left(\mathrm{k}_{1}\right)$ foi duas vezes maior para o sistema adaptado, enquanto que a constante de ordem zero $\left(\mathrm{k}_{2}\right)$ apresentou valor três vezes superior, aproximadamente. Para RM1, a constante de primeira ordem para conversão do nitrato foi cerca de $45 \%$ maior para o sistema adaptado. No entanto, nesse caso, a constante de ordem zero para conversão do nitrito não se alterou ao longo do tempo, indicando que a comunidade microbiana que converte nitrito já estava adaptada na Fase A.

Quando o metano foi utilizado como doador de elétrons (RM2), o parâmetro cinético de ordem zero, ou seja, a constante da velocidade de reação cresceu 58\%, após 
o reator ter sido considerado adaptado. Nesse caso, é importante notar que o parâmetro cinético obtido, após adaptação (Fase B), certamente inclui todas as etapas do processo, ou seja, pode ser adotado como o parâmetro representativo da desnitrificação completa, pois o nitrito foi consumido completamente ao longo do ensaio cinético. O mesmo não aconteceu na fase de adaptação, pois não houve consumo completo de nitrato e de nitrito.

O comportamento do reator RM2 foi claramente afetado por problemas de solubilidade do gás e pelos fenômenos de transferência de massa. As resistências externas e internas à transferência de massa dificultam o acesso da biomassa ao substrato, diminuindo a velocidade global do processo. Tendo em vista que não foi adotado qualquer procedimento que pudesse minimizar esses efeitos, o processo esteve sujeito a essas limitações. Contudo, os experimentos confirmaram a possibilidade de utilização de metano como doador de elétrons para a desnitrificação. Esse resultado é muito importante, uma vez que os problemas de natureza física podem ser resolvidos através do desenvolvimento de configurações de reatores apropriadas.

Após adaptação da biomassa, o reator RE alcançou 100\% de remoção de nitrogênio, após 50 minutos de reação. Foram necessários 120 e 385 minutos para que a mesma eficiência fosse alcançada nos reatores RM1 e RM2, respectivamente.

A constante cinética de primeira ordem, para consumo de nitrato, foi consideravelmente maior quando se utilizou o etanol como fonte de carbono e energia $\left(\mathrm{k}_{1}=4,43 \mathrm{~h}^{-1}\right)$, quando comparada à constante obtida no reator alimentado com metanol $\left(k_{1}=1,33 h^{-1}\right)$. Da mesma forma, a constante de velocidade de formação de $N_{2}$ foi significativamente maior quando a desnitrificação se deu na presença de etanol $\left(\mathrm{k}_{2}=\right.$ 6,63 mg/L.h - RE e k2 = 1,75 mg/L.h - RM1). De fato, observou-se que as velocidades globais de desnitrificação foram mais elevadas na presença de etanol que de metanol (Figura 17).

É importante ressaltar que, em RE e RM1, a velocidade de conversão de nitrito a $\mathrm{N}_{2}$ foi constante e independente da concentração de nitrito presente no meio (modelo de ordem zero).

A Figura 16 associa os perfis temporais de concentração de metanol e etanol aos perfis de consumo de nitrato obtidos para o sistema adaptado (fase B), para os reatores $\mathrm{RE}$ e RM1. Essa figura mostra que a relação $\mathrm{C} / \mathrm{N}$ igual a 1,0 foi adequada para promover a desnitrificação completa, ou seja, que não houve nem excesso, nem falta de carbono para que as funções celulares fossem mantidas e a respiração do nitrato 
realizada. De forma semelhante, Jianping et al. (2003) encontraram, para a relação C/N, a faixa de valores entre 0,95 e 1,0 como sendo os adequados para a desnitrificação quando metanol foi utilizado como doador exógeno de elétrons.

Os consumos de metanol e de etanol apresentaram o mesmo comportamento cinético obtido para a conversão de nitrato, em RE e RM1, cujo modelo cinético de consumo de nitrato é apresentado na eq. 9. Portanto, considerando-se reação de primeira ordem para o consumo de metanol e de etanol, as constantes cinéticas de primeira ordem foram obtidas para cada reator e encontram-se apresentadas na Tabela 22.
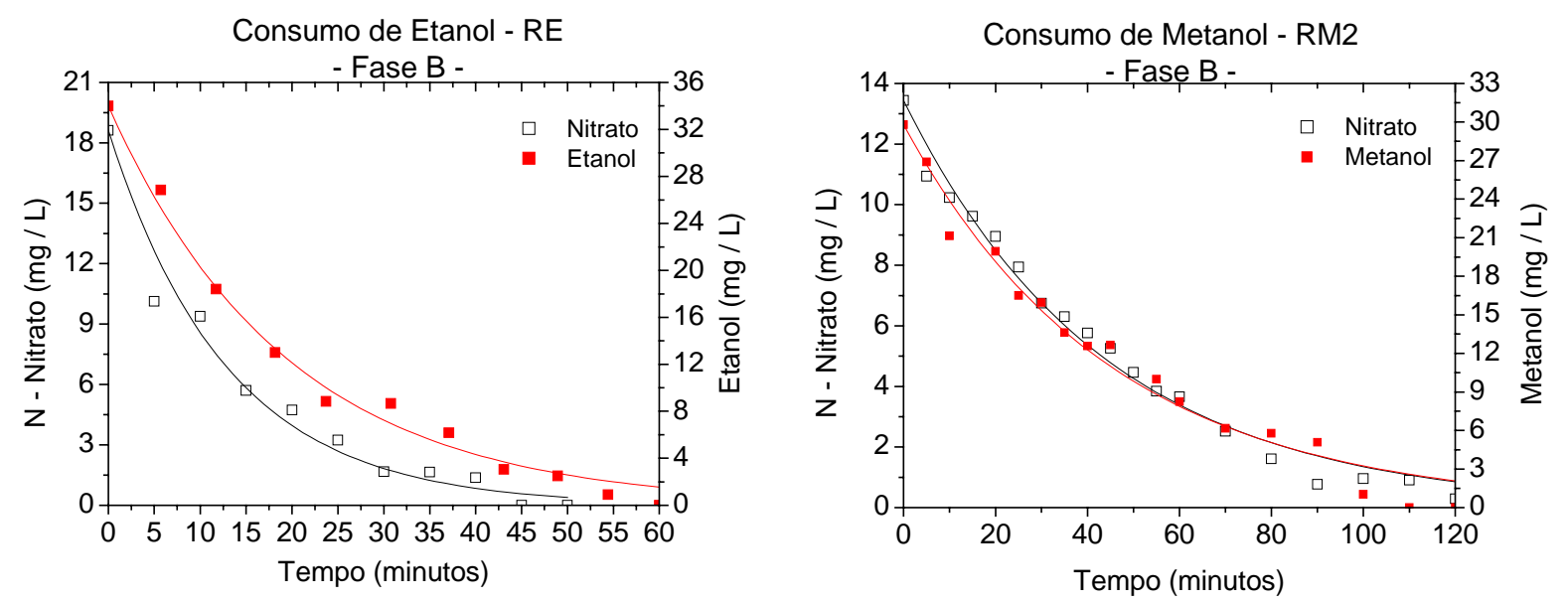

Figura 16. Consumo das fontes de carbono metanol e etanol, associados aos perfis temporais de concentração de nitrato (fase B).

É possível observar (Figura 16) que, aparentemente, o nitrato foi mais rapidamente consumido que o etanol (RE) e que o metanol (RM1) foi consumido exatamente à mesma velocidade que o nitrato.

Tabela 22. Parâmetros cinéticos obtidos para modelo de reação de primeira ordem para consumo de metanol e etanol

\begin{tabular}{ccc}
\hline \multirow{2}{*}{ Parâmetros cinéticos aparentes } & \multicolumn{2}{c}{ Doador de elétrons - Fase B } \\
\cline { 2 - 3 } & Etanol & Metanol \\
\hline $\mathrm{k}_{1}\left(\mathrm{~h}^{-1}\right)$ & $3,09 \pm 0,12$ & $1,33 \pm 0,05$ \\
$\mathrm{R}^{2}$ para primeira ordem & 0,990 & 0,976 \\
\hline
\end{tabular}

Analisando-se a Tabela 22, é possível observar que a constante cinética de primeira ordem para consumo de etanol $\left(\mathrm{k}_{1}=3,09 \mathrm{~h}^{-1}\right)$ foi , aproximadamente, $60 \%$ maior do que a de consumo de metanol $\left(\mathrm{k}_{1}=1,33 \mathrm{~h}^{-1}\right)$, confirmando, assim como foi observado para o consumo de nitrato, que o etanol foi mais rapidamente consumido do 
que o metanol. Dessa forma, é muito provável que os doadores de elétrons etanol e metanol tenham sido utilizados para a redução de nitrato do meio líquido.

As concentrações de nitrato, metanol e etanol, em mM, observadas nos reatores, foram iguais a $0,7 \mathrm{mM}$ de etanol e $1,21 \mathrm{mM}$ de nitrato, para RE e 0,994 $\mathrm{mM}$ de metanol e 1,0 mM de nitrato, para RM1. As relações estequiométricas (eq. 5 e 6) indicam que é necessário 1 mol de etanol para reduzir 2 moles de nitrato, quando o etanol é o doador de elétrons e que, $1 \mathrm{~mol}$ de metanol reduz $1 \mathrm{~mol}$ de nitrato, quando o metanol é o doador de elétrons.

É possível observar, portanto, que havia mais etanol $(0,7 \mathrm{mM})$ do que a quantidade requerida $(0,605 \mathrm{mM})$, enquanto que a proporção entre metanol e nitrato esteve bem próxima da requerida (1 mol de metanol : 1 mol de nitrato). Apesar de as relações $\mathrm{C} / \mathrm{N}$ terem sido as mesmas, nos dois reatores, a concentração de etanol encontrava-se em excesso para promover o processo de desnitrificação, pelo fato deste composto possuir dois carbonos e ser capaz de doar mais elétrons do que o metanol.

Em geral, os estudos sobre desnitrificação baseiam-se em valores da relação C/N (ou DQO/N) considerados ótimos, ou procuram estabelecer um valor ótimo, o qual passa a ser reportado como adequado para promover o processo de desnitrificação. No entanto, é importante observar que compostos diferentes como etanol e metanol, por exemplo, são capazes de doar quantidades de elétrons diferentes. Por esse motivo, quando é possível estabelecer um doador de elétrons específico, constatou-se ser mais adequado adotar-se a quantidade do doador de elétrons a ser introduzida avaliando-se, primeiramente, a capacidade que cada composto possui em doar elétrons. No entanto, algumas vezes não é possível estabelecer um doador específico de elétrons, como, por exemplo, no caso do uso de esgoto bruto como fonte de elétrons para a desnitrificação, o que torna necessária a utilização da relação DQO/N.

A Figura 17 apresenta os perfis temporais de velocidade de consumo de nitrato e nitrito para RE e RM1 (equações 5 e 6). Os perfis foram obtidos através da utilização dos parâmetros cinéticos apresentados na Tabela 20, considerando-se que o modelo cinético ajustado representou bem os dados experimentais.

O modelo cinético ajustado permitiu observar, nos dois casos, que a reação de conversão de nitrito a $\mathrm{N}_{2}$ foi o passo limitante do sistema reacional, pois essas velocidades se mantiveram inferiores às de conversão de nitrato a nitrito.

É importante destacar quando esse tipo de modelo é utilizado para representar reações que ocorrem em série, é esperado que a velocidade de consumo do produto 
intermediário seja a limitante do processo reacional. As velocidades de consumo de nitrato e de nitrito poderão ser, no máximo, iguais, no caso de consumo instantâneo de nitrito. Nesse caso, nenhuma concentração de nitrito seria detectada no meio líquido. Diante disso, do ponto de vista do processo de desnitrificação, torna-se difícil concluir que a velocidade de conversão de nitrito foi a limitante de sistema reacional, conforme sugerido pelo modelo cinético ajustado aos dados experimentais de nitrito.

As velocidades observadas na fase A (após dois meses) foram significantemente menores que aquelas observadas na fase B (após quatro meses) no reator RE. As velocidades variaram pouco no experimento com metanol. Os resultados obtidos para as maiores velocidades de conversão confirmaram que o etanol foi o doador de elétrons mais eficiente para a desnitrificação. Contudo, eles também indicaram que a biomassa adaptou-se mais rapidamente ao metanol.

A vantagem cinética de se utilizar etanol, em relação ao metanol, é claramente ilustrada na Figura 17. A velocidade de conversão de nitrato na fase B (80 mg/L.h para RE e $18 \mathrm{mg} / \mathrm{L} . h$, para RM1), em que a biomassa encontrava-se adaptada, foi aproximadamente quatro vezes maior com a utilização de etanol. Além disso, o tempo de ciclo de batelada para atingir a desnitrificação completa foi menor. Foram obtidas baixas velocidades de conversão (próximas de zero) após 30 minutos em RE, enquanto que 100 minutos foram necessários para RM1.

Louzeiro et al (2002) encontraram a velocidade máxima de desnitrificação igual a $19 \mathrm{mg} \mathrm{NO}_{3}{ }^{-}-\mathrm{N} / g S S V L M . d i a$, para reator seqüencial em batelada alimentado com 8,1 $\mathrm{mg} / \mathrm{L}$ de metanol. Este valor de velocidade foi estimado considerando-se a concentração de sólidos suspensos voláteis no licor misto (SSVLM). Os autores também observaram velocidades distintas no sistema com e sem metanol, no início e no final do ciclo. Em ambos os casos, o composto intermediário (nitrito) formado não foi considerado e o modelo cinético de ordem zero foi ajustado para a conversão direta de nitrato a $\mathrm{N}_{2}$. Neste trabalho, a velocidade de desnitrificação obtida para RM1, na fase B, foi de 32 mg $\mathrm{N}^{-\mathrm{NO}_{3}}{ }^{-}$/g STVLM.dia, isto é, 70\% maior do que a obtida por Louzeiro et al (2002), provavelmente devido à disponibilidade de metanol durante todo o processo de desnitrificação. 


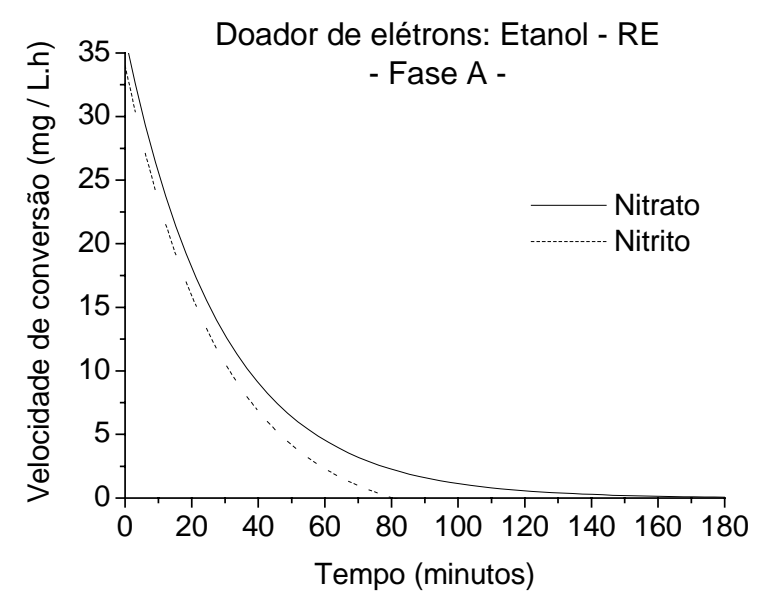

(a)

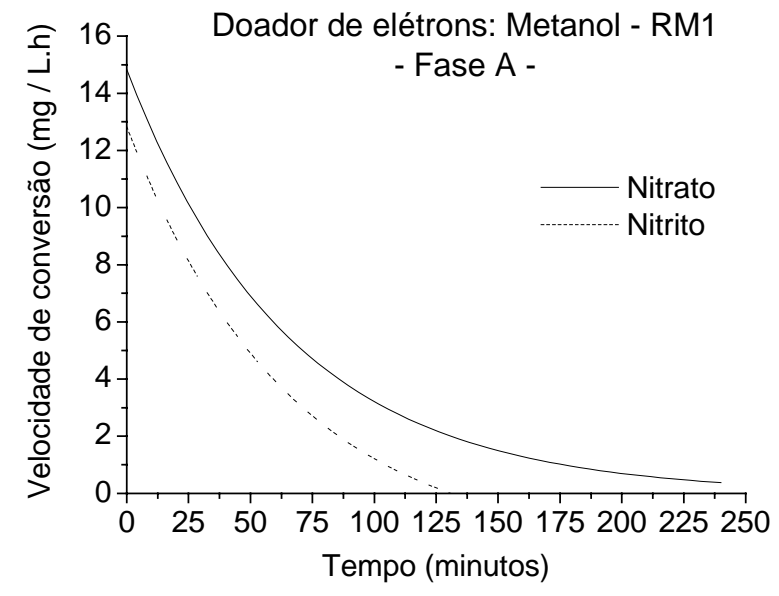

(c)

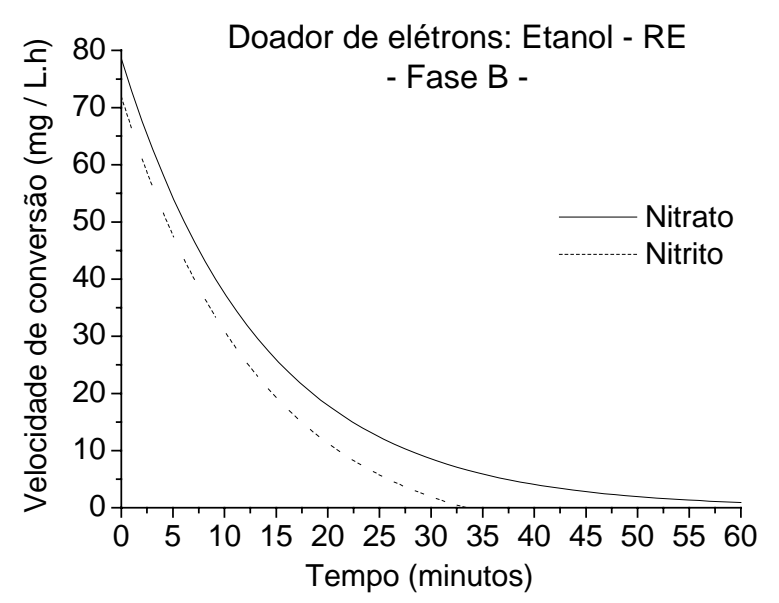

(b)

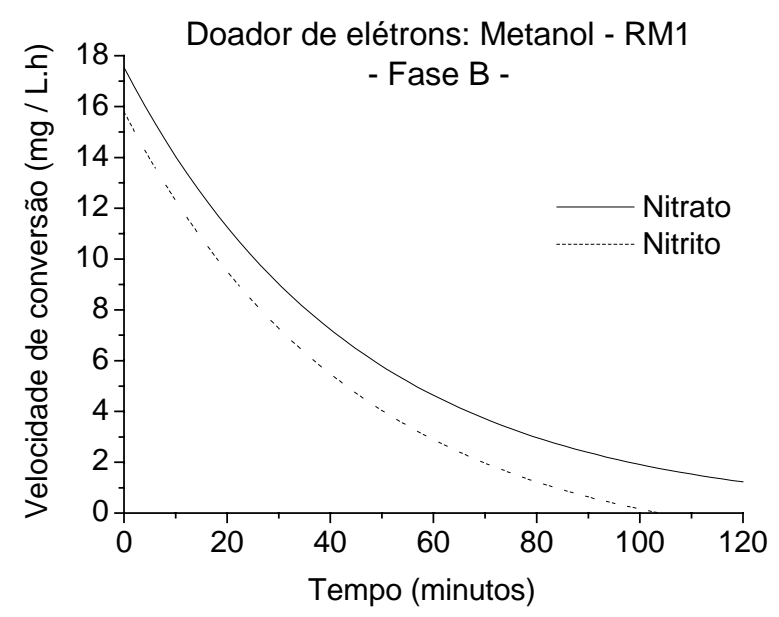

(d)

Figura 17 Perfis temporais de velocidade de consumo de nitrato e nitrito, para os reatores: (a) RE - fase A; (b) RE - fase B; (c) RM1 - fase A e (d) RM1 - fase B. A relação C/N foi igual a 1,0.

A alcalinidade produzida durante a desnitrificação depende da fonte de carbono utilizada. Em todas as equações apresentadas na Tabela 23, para cada mol de $\mathrm{N}$ reduzido na forma de nitrato, ocorre a produção de um mol de $\mathrm{OH}^{-}$ou $50 \mathrm{~g}$ de alcalinidade, na forma de $\mathrm{CaCO}_{3}$. Dessa forma, foi possível obter a alcalinidade teórica produzida no processo de desnitrificação, para os três doadores de elétrons utilizados (Tabela 23). No caso do metano, para a obtenção do valor teórico da alcalinidade, foi considerada a solubilidade do gás, a $17^{\circ} \mathrm{C}$, igual a $3,5 \mathrm{~mL} / 100 \mathrm{~mL}$.

A Tabela 24 apresenta os valores de alcalinidade total a bicarbonato produzida em cada fase dos três reatores desnitrificantes. Baseado no erro de $10 \%$, inerente ao método utilizado para determinação da alcalinidade, é possível observar que os valores teóricos foram bem reproduzidos nas fases A e B dos reatores RE e RM1 e na fase A, para RM2. 
Tabela 23. Alcalinidade teórica produzida durante a desnitrificação.

\begin{tabular}{ccc}
\hline $\begin{array}{c}\text { Doador de } \\
\text { elétrons }\end{array}$ & $\begin{array}{c}\mathrm{AT} \\
\left(\mathrm{mg} \mathrm{CaCO}_{3} / \mathrm{L}\right)\end{array}$ & Equação estequiométrica simplificada \\
\hline Etanol & 99,91 & $12 \mathrm{NO}_{3}^{-}+5 \mathrm{CH}_{3} \mathrm{CH}_{2} \mathrm{OH} \rightarrow 6 \mathrm{~N}_{2}+10 \mathrm{CO}_{2}+9 \mathrm{H}_{2} \mathrm{O}+12 \mathrm{OH}^{-}$ \\
Metanol & 99,94 & $6 \mathrm{NO}_{3}^{-}+5 \mathrm{CH}_{3} \mathrm{OH} \rightarrow 3 \mathrm{~N}_{2}+5 \mathrm{CO}_{2}+7 \mathrm{H}_{2} \mathrm{O}+6 \mathrm{OH}^{-}$ \\
Metano & 125 & $8 \mathrm{NO}_{3}{ }^{-}+5 \mathrm{CH}_{4} \rightarrow 4 \mathrm{~N}_{2}+5 \mathrm{CO}_{2}+6 \mathrm{H}_{2} \mathrm{O}+8 \mathrm{OH}^{-}$ \\
\hline
\end{tabular}

Tabela 24 Alcalinidade a bicarbonato produzida durante o processo de desnitrificação

\begin{tabular}{|c|c|c|c|c|c|c|}
\hline \multirow{2}{*}{ Parâmetro } & \multicolumn{2}{|c|}{ Etanol } & \multicolumn{2}{|c|}{ Metanol } & \multicolumn{2}{|c|}{ Metano } \\
\hline & Fase A & Fase B & Fase A & Fase B & Fase A & Fase B \\
\hline $\begin{array}{c}\text { Alcalinidade a bicarbonato produzida - } \\
\mathrm{AB}\left(\mathrm{mg} \mathrm{CaCO}_{3} / \mathrm{L}\right)\end{array}$ & 76,74 & 64,22 & 70,03 & 61,34 & 68,11 & 28,15 \\
\hline $\begin{array}{l}\text { Nitrogênio reduzido- } \mathrm{N}_{\text {red }} \\
\text { (mg N/L) }\end{array}$ & 18,54 & 18,61 & 18,53 & 13,45 & 1,25 & 13,54 \\
\hline $\begin{array}{c}\mathrm{AB}_{\text {prod }} / \mathrm{N}_{\text {red }}^{*} \\
\left(\mathrm{mg} \mathrm{CaCO}_{3} / \mathrm{mg} \mathrm{N}\right)\end{array}$ & 4,14 & 3,45 & 3,78 & 4,56 & 54,5 & 2,08 \\
\hline $\mathrm{pH}$ inicial & 7,34 & 7,15 & 7,30 & 7,51 & 7,30 & 7,79 \\
\hline $\mathrm{pH}$ final & 7,52 & 7,29 & 7,53 & 7,71 & 7,52 & 8,02 \\
\hline
\end{tabular}

A proporção alcalinidade a bicarbonato gerada por nitrogênio reduzido ( $\mathrm{AB}_{\text {prod}}$ ) $\mathrm{N}_{\text {red}}$ ) foi determinada a partir dos dados das formas oxidadas de nitrogênio (nitrato e nitrito). Os resultados desta proporção, obtidos para RM1 e RE (3,78 e 4,56; 4,14 e 3,45 mg $\mathrm{CaCO}_{3} / \mathrm{mg} \mathrm{N}$, para as fases $\mathrm{A}$ e $\mathrm{B}$, respectivamente), foram próximos do valor teórico (3,57 $\mathrm{mg} \mathrm{CaCO}_{3} / \mathrm{mg} \mathrm{N}$ ), apesar do desvio (cerca de 30\%) entre os valores experimentais e teóricos de alcalinidade a bicarbonato. Contudo, maiores desvios (42\%) foram encontrados em RM2 na fase B, provavelmente devido a problemas de solubilidade e resistência à transferência de massa.

Valores aparentemente anormais de $A B_{\text {prod }} / N_{\text {red }}$ foram observados em RM2 na fase A. O elevado valor de alcalinidade a bicarbonato gerada foi incompatível com a quantidade de nitrogênio (nitrato e nitrito) reduzida. Isto pode ser atribuído ao crescimento de organismos metanogênicos, que utilizam produtos intermediários das bactérias metanotróficas, como metanol (MADIGAN et al, 1997) ou ácido acético (COSTA et al, 2000). Conseqüentemente, organismos metanogênicos podem ter tido uma vantagem competitiva sobre os desnitrificantes na fase de adaptação, gerando, deste modo, alcalinidade a bicarbonato. De fato, arqueas semelhantes ao gênero Methanosarcina, que utilizam metanol e acetato, foram observadas, através de microscopia óptica, no lodo da fase A. A quantidade observada desses microrganismos foi menos significante na fase $B$, em que a alcalinidade produzida foi menor que a esperada, tomando-se como base a relação estequiométrica. 
A concentração de sólidos totais, presentes no licor misto, não apresentou variação significativa entre as fases A e B, nos três reatores. Valores próximos a 9,5 g STV/L, 13,0 g STV/L e 7,6 g STV /L foram observados em RE, RM1 e RM2, respectivamente.

No início da operação dos reatores e durante a realização dos perfis temporais de concentração de nitrato e nitrito, na fase A, foi empregado o método da DQO para quantificação das fontes de carbono específicas. A utilização desse método mostrou-se inadequada, pois as concentrações de matéria orgânica eram muito baixas, o que provocou aumento do erro experimental. Além disso, as presumíveis fontes de carbono quantificadas como DQO não representavam, necessariamente, aquelas utilizadas para a desnitrificação. Por esse motivo, foi realizada uma adaptação na metodologia proposta por Corrêa e Pedroso (1997) e publicada por Santos et al. (2002b), cuja aplicação permitiu quantificar as fontes de carbono metanol e etanol diretamente.

O avanço do processo de desnitrificação, durante a fase de adaptação, foi acompanhado pelo aumento na concentração celular de microrganismos desnitrificantes. No lodo granulado utilizado como inóculo, foi observada concentração de 8,4.10 ${ }^{7}$ $\mathrm{NMP} / \mathrm{g}$ STV, com predomínio de coco-bacilos e bacilos delgados. Nos sistemas adaptados (fase B), a maior concentração foi verificada em RE, com valor igual a 5,3.10 NMP/g STV. Para RM1 e RM2, os valores foram iguais a 2,07.10 ${ }^{9} \mathrm{NMP} / \mathrm{g}$ STV, $1,71.10^{9} \mathrm{NMP} / \mathrm{g}$ STV, respectivamente. Nas maiores diluições aplicadas no uso da técnica do número mais provável (NMP), após adaptação, foi observado o predomínio de bacilos, nas três condições estudadas. Esses resultados comprovaram o desenvolvimento de microrganismos desnitrificantes e demonstraram a relação entre eficiência e concentração celular nos reatores anóxicos.

\subsubsection{Relação $C / N=0,75$ (Fase $C$ )}

As Figuras 19 e 20 apresentam os dados referentes ao monitoramento dos parâmetros nitrato e nitrito, durante os dois meses de operação dos reatores desnitrificantes RM1 e RM2, com a relação C/N igual a 0,75. Os resultados obtidos durante o monitoramento de RE não são apresentados, pois as concentrações de nitrato e nitrito, presentes no efluente de todas as bateladas, mantiveram-se abaixo do limite de detecção do método utilizado para quantificação destes parâmetros. 
Doador de elétrons: Metanol - RM1

Relação $\mathrm{C} / \mathrm{N}=0,75$

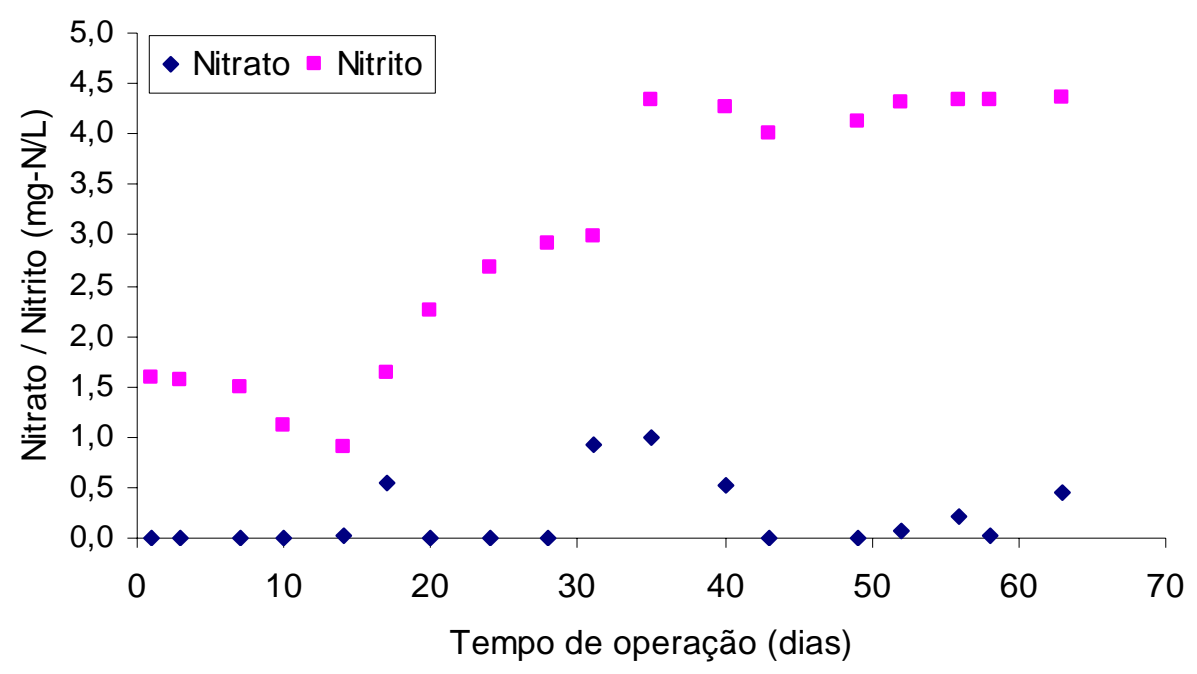

Figura 18. Concentrações de nitrato e de nitrito, no efluente do reator RM1 (C/N = 0,75).

Doador de elétrons: Metano - RM2

Alimentação sem oxigênio

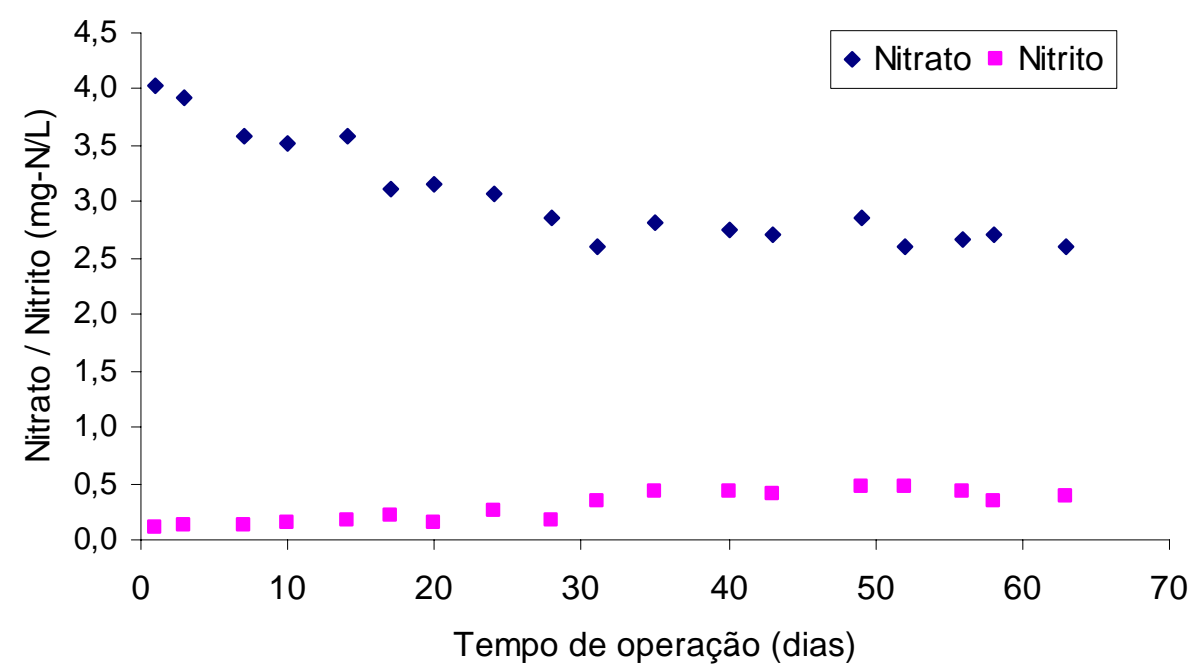

Figura 19. Concentrações de nitrato e de nitrito, no efluente do reator RM2 (ausência de oxigênio).

Após a mudança da relação C/N para 0,75 (Figura 18), a concentração de nitrito, no efluente de RM1, aumentou gradativamente, até se estabilizar em torno de 4,0 mgN/L. A quantidade de metanol adicionada não foi suficiente para promover a desnitrificação completa e a população consumidora de nitrito foi a mais prejudicada com a mudança da relação $\mathrm{C} / \mathrm{N}$.

Comportamento oposto foi observado em RM2 (Figura 19), em que a concentração de nitrato foi de, aproximadamente, 4,0 mg $\mathrm{N}-\mathrm{NO}_{3}{ }^{-} / \mathrm{L}$, já no efluente do primeiro ciclo de batelada, enquanto que a concentração de nitrito se manteve abaixo de $1,0 \mathrm{mg} \mathrm{N}-\mathrm{NO}_{2}{ }^{-} / \mathrm{L}$. Nesse caso, a população redutora de nitrato parece ter sido mais 
sensível à falta de oxigênio do que a redutora de nitrito. Parece ser comum a ocorrência de baixas concentrações de nitrito em reatores desnitrificantes que utilizam metano como doador de elétrons. Thalasso et al (1997) operaram reator desnitrificante, na presença de metano e oxigênio, não tendo observado formação de nitrito durante o processo de desnitrificação.

A concentração de nitrogênio amoniacal, no efluente de todos os reatores, não apresentou variação significativa e manteve-se próxima de 8,2 mg-N/L; 5,5 mg-N/L e 8,4 mg-N/L, para RM1, RE e RM2, respectivamente. A manutenção desses níveis de concentração de nitrogênio amoniacal no efluente dos reatores ocorreu desde que a estabilidade foi alcançada, nas fases anteriores (Figuras 13 a 15). Duas hipóteses podem ser aventadas: a primeira refere-se à continuidade do processo de autólise de material celular inativo, decorrente da constante seleção dos microrganismos; a segunda relaciona-se com a possível competição entre bactérias desnitrificantes e bactérias que promovem a RDNA (redução dissimilativa de nitrato a amônia) a partir do nitrato presente no meio.

A primeira hipótese é confirmada através dos resultados de microscopia óptica, conforme será discutido no item 6.1.5. Foi possível verificar que ocorreu seleção das morfologias presentes no inóculo, chegando a ponto de, em alguns casos, a estrutura do grânulo servir de material suporte para crescimento de microrganismos.

A segunda hipótese é apresentada por Guynot et al (1998), em que os autores observaram que a produção de $\mathrm{N}$-amoniacal aumentou no reator desnitrificante com o aumento da relação C/N. Para a menor relação estudada, C/N igual a 1,12, medida como glicose, foi observado que aproximadamente $20 \%$ do nitrato presente foi reduzido para $\mathrm{N}$-amoniacal. Essa porcentagem chegou a $45 \%$, quando a relação $\mathrm{C} / \mathrm{N}$ foi igual a 4,5. Os autores concluíram pela necessidade de se conhecer os fatores que influenciam a competição entre microrganismos desnitrificantes e produtores de amônia, para melhorar o desempenho dos reatores desnitrificantes.

O monitoramento dos parâmetros $\mathrm{pH}$, alcalinidade e ácidos voláteis (Tabela 25) mostrou haver maior estabilidade nos reatores, quando comparados com as fases anteriores (fases A e B), pois tais parâmetros não apresentaram variações significativas ao longo do período de operação.

Observa-se, comparando-se com a fase anterior, que houve aumento do $\mathrm{pH}$ no efluente de RM1 e RE, que se manteve superior a 8,0. Esse aumento de $\mathrm{pH}$ deve ter sido 
proporcionado pelo sensível aumento da alcalinidade a bicarbonato nos reatores desnitrificantes, conforme apresentado na Tabela 25.

A alcalinidade a bicarbonato produzida em RM2 (184 mg $\mathrm{CaCO}_{3} / \mathrm{L}$ ), na ausência de oxigênio, foi consideravelmente maior, quando comparada com a produzida durante as fases $\mathrm{A}$ e $\mathrm{B}\left(125 \mathrm{mg} \mathrm{CaCO}_{3} / \mathrm{L}\right)$, na presença de oxigênio, talvez devido à possível inativação de populações que participam de etapas intermediárias do processo de desnitrificação.

Apesar da ausência de oxigênio em RM2, não foi observada diminuição da concentração de ácidos voláteis, em relação às fases anteriores. É possível que, caso tenha havido produção de ácidos por bactérias metanotróficas nas fases A e B, estes tenham sido rapidamente consumidos por microrganismos desnitrificantes. Por outro lado, deve-se considerar que o método titulométrico empregado, para quantificação dos ácidos, não é suficientemente sensível para detectar tal diferença.

Tabela 25. Resumo dos resultados provenientes do monitoramento dos reatores.

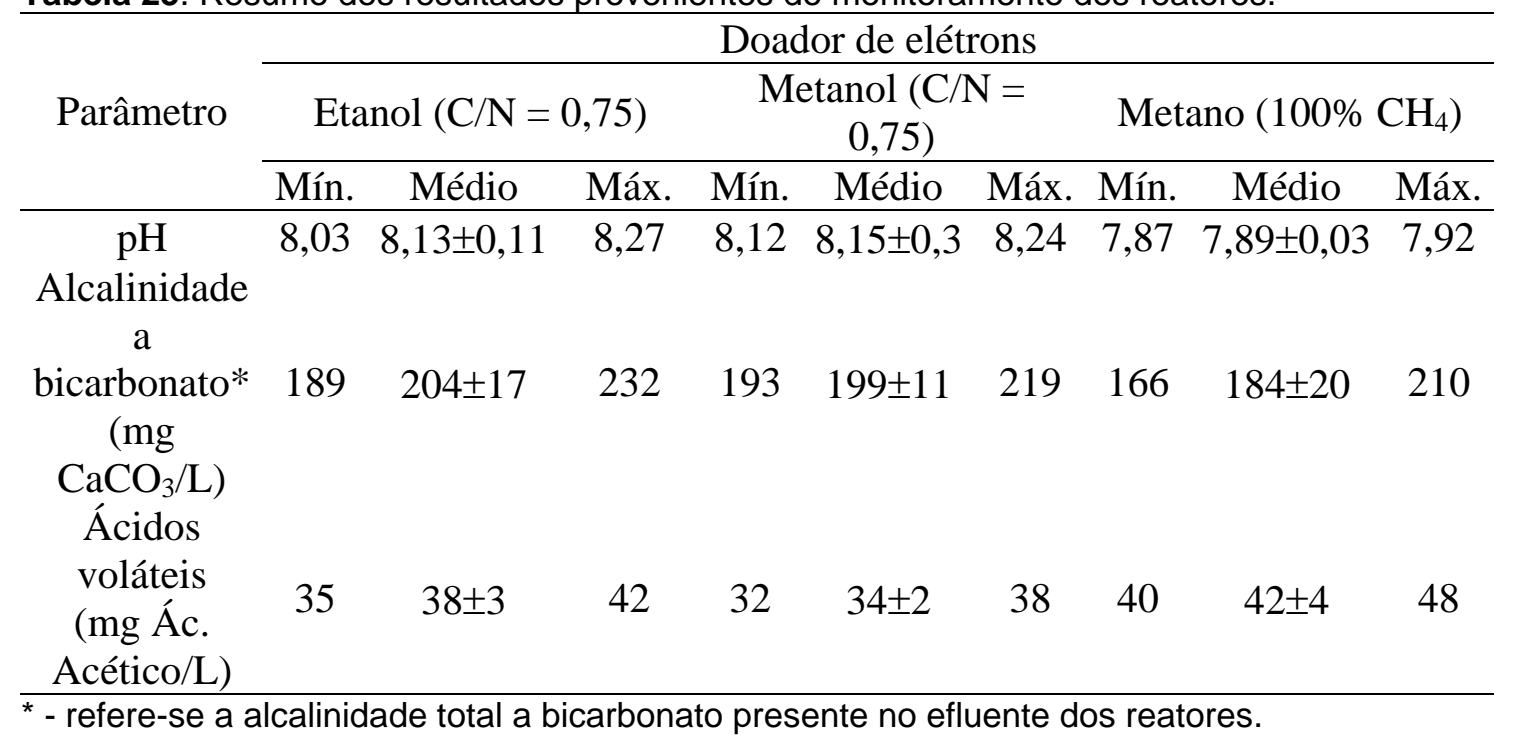

A Figura 20 mostra o ajuste dos modelos cinéticos aos dados experimentais de consumo de nitrato, nitrito, metanol e etanol observados, na fase $\mathrm{C}$, dos reatores RE, RM1 e RM2. Os perfis temporais de concentração foram obtidos após 60 dias de operação com a relação C/N igual a 0,75 (fase C), para RM1 e RE e operação sem oxigênio, para RM2.

Em nenhum dos casos foi possível obter ajuste razoável aos dados experimentais de nitrito. Acredita-se que a indisponibilidade da fonte de carbono para promover a completa redução de nitrato e de nitrito fez com que o comportamento cinético, 
principalmente de consumo de nitrito, fosse modificado. Nesse caso, ficou claro que grupos de microrganismos diferentes participaram do processo de redução de nitrato e de nitrito, decorrentes da utilização dos doadores específicos de elétrons e de fontes endógenas de carbono.

Os dados experimentais de consumo de metanol e de etanol são apresentados juntamente com os dados de remoção de nitrato e de nitrito. Os modelos utilizados para representar os dados experimentais foram de reação de ordem zero (eq. 12) e de primeira ordem (eq. 13), cujas expressões gerais são apresentadas a seguir:

$$
\begin{aligned}
& C_{A}=C_{A 0}-k_{0} t \\
& C_{A}=C_{A 0} \cdot e^{-k 1 . t}
\end{aligned}
$$

O índice A foi utilizado para representar a concentração de nitrato, metanol ou etanol, dependendo dos dados experimentais em questão. Desta forma, $\mathrm{C}_{\mathrm{A}}$ é a concentração de $A$ em mg /L (para nitrato, $C_{A}$ é dada em mg-N/L); $k_{1}$, a constante de reação de primeira ordem e $\mathrm{k}_{0}$, a constante de reação de ordem zero. O índice (o) subscrito indica a concentração inicial.

É possível observar que tanto a concentração de metanol, quanto a de etanol foram insuficientes para promover a desnitrificação completa. Fontes internas de carbono (endógenas), provavelmente, devem ter sido utilizadas para promover a desnitrificação após o metanol e o etanol terem sido completamente consumidos. Para o reator RM1, foi clara a ocorrência de duas velocidades de consumo de nitrato. Ambas seguiram reação de ordem zero; a primeira quando metanol foi utilizado como doador de elétrons ( $1^{\mathrm{a}}$ velocidade de consumo de nitrato - Figura 20a) e a segunda, quando, provavelmente, foram utilizadas fontes internas de carbono $\left(2^{\mathrm{a}}\right.$ velocidade de consumo de nitrato - Figura 20a).

Louzeiro et al (2002) observaram, durante operação de reator seqüencial em batelada desnitrificante, em escala real, duas velocidades de desnitrificação distintas. Os autores suspeitam que a elevada velocidade inicial observada foi resultado da utilização do metanol, disponível para a desnitrificação. Após o metanol ter sido consumido, o processo de desnitrificação continuou pela utilização de outras fontes de carbono presentes no afluente ou por desnitrificação endógena. As velocidades foram determinadas a partir de reação de ordem zero, para relação C/N igual a 2,34 (ou 4,1 mg $\mathrm{CH}_{3} \mathrm{OH} / \mathrm{L}$ para $3,6 \mathrm{mg} \mathrm{N}-\mathrm{NO}_{3}{ }^{-} / \mathrm{L}$ ) e temperatura de $13,6^{\circ} \mathrm{C}$, tendo resultado em valores iguais a 48,40 mg-N/L.h e 15,27 mg-N/L.h, respectivamente. Observa-se que a 
utilização de fonte interna de carbono (representada pelo segundo valor) resultou em velocidade de desnitrificação significativamente menor que a resultante da utilização de metanol (representada pelo primeiro valor).

Neste trabalho, as duas velocidades de desnitrificação observadas na presença de metanol foram: 8,05 mg-N/L.h e 0,78 mg-N/L.h para a primeira e para a segunda velocidade, respectivamente. Esses valores de velocidade foram muito inferiores aos observadas por Louzeiro et al (2002), provavelmente devido às condições deste trabalho serem bastante distintas. A principal influência se deve à relação $\mathrm{C} / \mathrm{N}$ que foi de 0,75 , ou seja, a quantidade de metanol disponível para reduzir nitrato foi $68 \%$ inferior à utilizada por Louzeiro et al (2002).

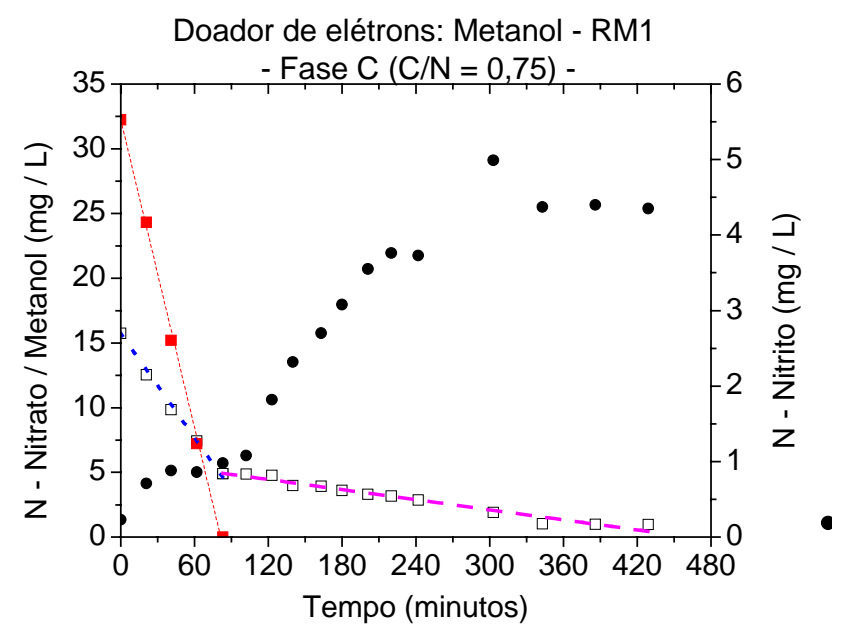

(a)

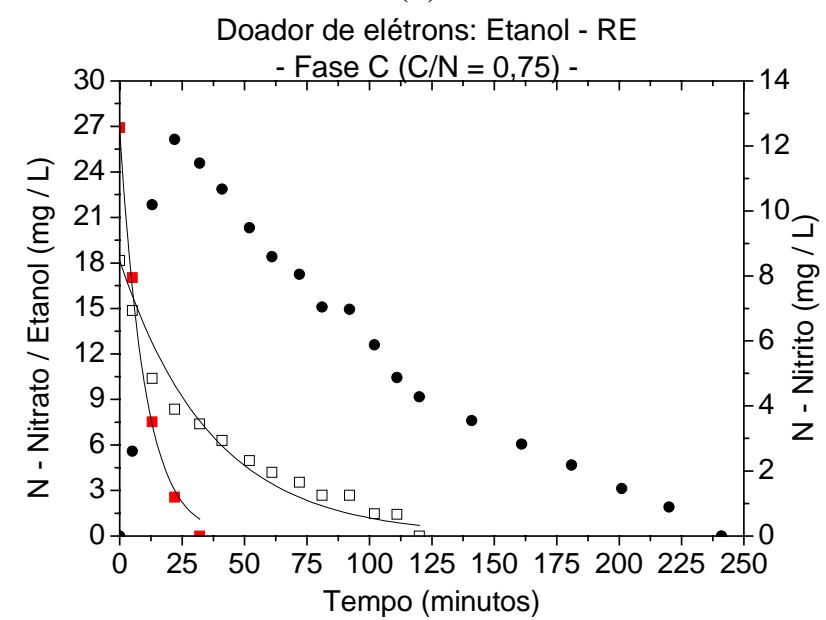

(c)

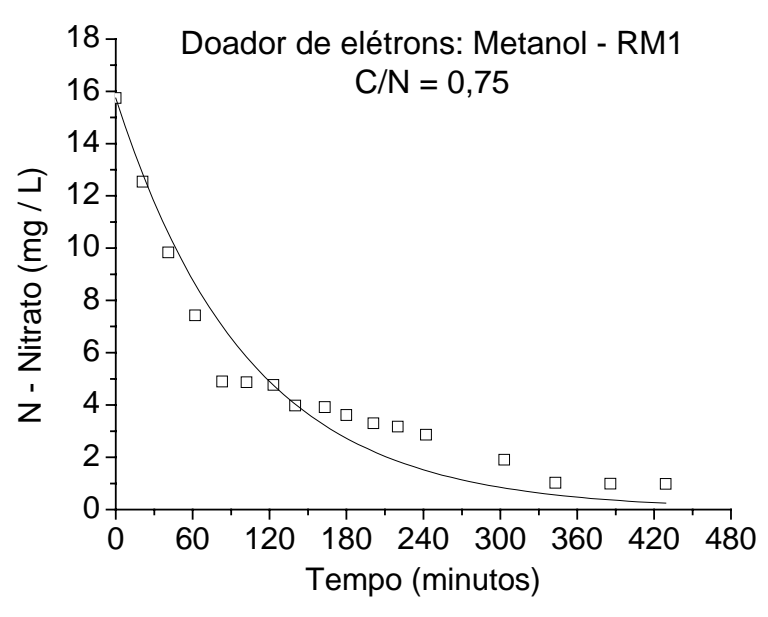

(b)

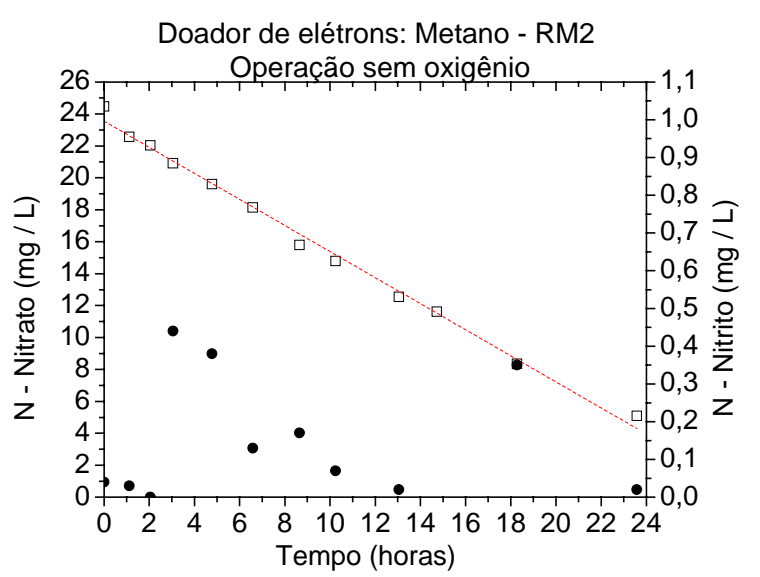

(d)

$\square \quad$ Dados experimentais de Nitrato - Dados experimentais de Metanol / Etanol

- Dados experimentais de Nitrito - - - Modelo cinético (eq. 12) Modelo cinético (eq. 13)

.... . Modelo (eq. 12) ajustado a $1^{\mathrm{a}}$ velocidade de consumo de nitrato (Fig. a) Modelo (eq. 12) ajustado a $2^{\mathrm{a}}$ velocidade de consumo de nitrato (Fig. a)

Figura 20. Perfis de concentração de nitrato, nitrito, metanol e etanol na fase $\mathrm{C}$ para os reatores: (a) e (b) RM1 - C/N = 0,75, (c) RE - C/N = 0,75 e (d) RM2 (100\% $\left.\mathrm{CH}_{4}\right)$. 
Fato semelhante, em relação à ocorrência de duas velocidades de desnitrificação, foi, aparentemente, observado para os dados experimentais de nitrito em RM1 e RE.

No reator RE (Figura 20c), ocorreu a rápida formação de nitrito, quando etanol ainda encontrava-se disponível no meio, sendo a máxima concentração atingida (12 mg -N/L) em 22 minutos. Por outro lado, foram necessários 220 minutos para o desaparecimento completo de nitrito; ou seja, foi gasto o tempo 100 vezes maior para o consumo que para a formação de nitrito. Nesse caso, é possível constatar que a população consumidora de nitrito foi, aparentemente, a mais prejudicada, talvez devido ao fato de as fontes internas de carbono serem mais complexas e, portanto, não serem diretamente assimiláveis pelas bactérias desnitrificantes, como o etanol. Esse fato jamais poderia ter sido observado durante o monitoramento do reator, pois as concentrações de nitrato e de nitrito no efluente sempre se mantiveram próximas de zero.

No caso de RM1, já era esperado que o nitrito não fosse completamente consumido, devido à sua presença no efluente desse reator, durante a fase de monitoramento. Após 83 minutos (Figura 20a), observa-se a formação de um patamar, com concentração de N-nitrito em torno de 1,0mg/L. Ocorreu, neste ponto, um aparente desequilíbrio da reação de desnitrificação, entre formação e consumo do intermediário nitrito, e este passou a ficar acumulado no meio, devido à ausência de fontes disponíveis de carbono para promover seu consumo. Esse aparente desequilíbrio esteve associado à mudança na inclinação da reta de consumo de nitrato, que acarretou a ocorrência de duas velocidades de consumo desse composto.

Para o reator RM1, o modelo cinético de primeira ordem (eq. 13) também representou bem os dados experimentais de nitrato, sem considerar a ocorrência de duas velocidades durante seu consumo. Para efeito de comparação entre os doadores de elétrons, será considerado o ajuste ao modelo cinético considerando-se reação de primeira ordem (Figura 20b), que foi utilizado para representar os dados de nitrato deste reator na fase anterior (fase $B$ ). De forma semelhante, o modelo cinético de primeira ordem também representou bem os dados experimentais de consumo de nitrato, quando o etanol foi o doador de elétrons.

Os resultados do consumo das fontes de carbono, metanol e etanol, permitiram realizar ajustes aos dados experimentais, considerando-se reação de ordem zero e de primeira ordem, respectivamente. No entanto, tais ajustes não serão discutidos, pois foram realizados baseados apenas em quatro pontos experimentais. 
No caso do RM2 (Figura 20d), a concentração de nitrito manteve-se abaixo de 0,5 mg-N/L, indicando que a população consumidora de nitrito encontrava-se bem estabelecida nesse reator, contrariamente ao que foi observado em RM1 e RE. O mesmo modelo cinético de reação de ordem zero, que representou os dados experimentais de nitrato na fase anterior (fase B), também foi utilizado para representar os dados experimentais de nitrato nesta fase. Isto indica que a ausência de oxigênio não afetou o comportamento cinético dos microrganismos consumidores de nitrato. No entanto, aumento significativo, no tempo necessário para seu consumo, foi observado entre as fases B e C. Na presença de oxigênio (fase B), aproximadamente 385 minutos foram necessários para a desnitrificação completa, enquanto que, na ausência de oxigênio (fase C), a desnitrificação não foi completa mesmo após 24 horas.

Mesmo com carência das fontes de carbono, em RM1 e RE, e ausência de oxigênio, em RM2, mais uma vez o etanol foi o doador de elétrons mais eficiente para a desnitrificação. Tal processo foi completo após 240 e 440 minutos, para etanol e metanol, respectivamente, enquanto que, após 24 horas, ainda foram detectados 4 mgN/L de nitrato, em RM2. Além disso, o nitrato foi completamente consumido após 120 minutos em RE.

Na Tabela 26, são apresentados os parâmetros cinéticos obtidos para RM1 e RE, enquanto a Tabela 27 apresenta os parâmetros obtidos para RM2, na fase C.

Os sistemas eram considerados estáveis quando as concentrações de nitrato e de nitrito não apresentavam variação entre uma batelada e outra. A estabilização ocorreu após, aproximadamente, 2 meses de operação para todos os sistemas.

Tabela 26. Parâmetros cinéticos obtidos para os reatores RE e RM1, fase C.

\begin{tabular}{ccccc}
\hline \multirow{2}{*}{$\begin{array}{c}\text { Parâmetros cinéticos } \\
\text { aparentes }\end{array}$} & \multicolumn{3}{c}{ Doador de elétrons - Fase C (C/N = 0,75) } \\
\cline { 2 - 5 } & $\begin{array}{c}\text { Etanol } \\
\text { (eq. 13) }\end{array}$ & $\begin{array}{c}\text { Nitrato } \\
\text { (eq. 13) }\end{array}$ & $\begin{array}{c}\text { Metanol } \\
\text { (eq. 12) }\end{array}$ & $\begin{array}{c}\text { Nitrato } \\
\text { (eq. 13) }\end{array}$ \\
\hline $\mathrm{k}_{1}\left(\mathrm{~h}^{-1}\right)$ & $5,97 \pm 0,28$ & $1,64 \pm 0,09$ & - & $0,58 \pm 0,03$ \\
$\mathrm{k}_{0}(\mathrm{mg} / \mathrm{L} . \mathrm{h})$ & - & & $23,77 \pm 0,31$ & \\
$\mathrm{R}^{2}$ para primeira ordem & 0,996 & 0,961 & - & 0,942 \\
$\mathrm{R}^{2}$ para ordem zero & - & & 0,998 & \\
\hline
\end{tabular}

Tabela 27. Parâmetros cinéticos obtidos para reator RM2, fase C

\begin{tabular}{cc}
\hline \multirow{2}{*}{ Parâmetros cinéticos aparentes } & Metano - Fase C $\left(100 \% \mathrm{CH}_{4}\right)-\mathrm{RM} 2$ \\
\cline { 2 - 2 } & Nitrato \\
\hline $\mathrm{k}_{0}(\mathrm{mg} / \mathrm{L} . \mathrm{h})$ & 0,82 \\
$\mathrm{R}^{2}$ para ordem zero & 0,994 \\
\hline
\end{tabular}


Os resultados obtidos, em RM1 e RE, mostram que o desempenho da biomassa foi prejudicado pelo esgotamento antecipado das fontes de carbono, na fase C. A constante cinética de primeira ordem $\left(\mathrm{k}_{1}\right)$, para consumo de nitrato, foi 2,7 e 2,3 vezes menor na fase $\mathrm{C}\left(\mathrm{k}_{1}=1,64 \mathrm{~h}^{-1}\right.$ - etanol; $\mathrm{k}_{1}=0,58 \mathrm{~h}^{-1}$ - metanol $)$ do que na fase $\mathrm{B}\left(\mathrm{k}_{1}=\right.$ 4,43 $\mathrm{h}^{-1}$ - etanol; $\mathrm{k}_{1}=1,33 \mathrm{~h}^{-1}-$ metanol), para RE e RM1, respectivamente. Tais valores comprovaram a perda da eficiência observada entre as fases B e C.

Na fase $\mathrm{C}$, a constante cinética de primeira ordem $\left(\mathrm{k}_{1}\right)$, para consumo de nitrato, foi, aproximadamente, 65\% maior para RE que para RM1, confirmando, assim, a manutenção do melhor desempenho do reator com etanol em relação aos demais, conforme havia sido observado na fase B.

Apesar de não ter sido possível obter ajuste cinético aos dados experimentais de nitrito, ficou claro, para o reator RE (Figura 20c), que a velocidade de consumo de nitrito representou a etapa limitante do processo, pois este foi consumido 220 minutos depois que a concentração de nitrato chegou a zero. Nesse caso ficou claro que a limitação foi devida à indisponibilidade da fonte de carbono para redução total de nitrito.

Para RM2, o parâmetro cinético de ordem zero, ou seja, a velocidade constante de consumo de nitrato, diminuiu 65\% na ausência de oxigênio $\left(\mathrm{k}_{0}=0,82 \mathrm{mg} / \mathrm{L} \cdot \mathrm{h}-\right.$ fase C), em relação à fase anterior $\left(\mathrm{k}_{0}=2,37 \mathrm{mg} / \mathrm{L} . \mathrm{h}\right.$ - fase $\left.\mathrm{B}\right)$, em que o processo se desenvolveu na presença de oxigênio. A perda de eficiência, observada entre as fases B e C, pode ter ocorrido devido à falta do produto intermediário, produzido por organismos metanotróficos, que servia como doador de elétrons e fonte de carbono para as bactérias desnitrificantes.

A velocidade de desnitrificação, observada na ausência de oxigênio, foi igual a 0,82 mg/L.h. Este valor, além de muito baixo, foi próximo à segunda velocidade de consumo de nitrato, igual a 0,78 mg/L.h, observada no reator com metanol, após este ter sido completamente consumido (Figura, 21a), em que foi considerado ter havido desnitrificação endógena. Diante disso, não é possível afirmar que houve utilização de metano diretamente por microrganismos desnitrificantes, uma vez que tal hipótese não está bem estabelecida (MECHSNER e HAMER, 1985; THALASSO et al, 1997).

As velocidades de consumo de nitrato, para os reatores alimentados com metanol e etanol, são apresentadas na Figura 21. Observa-se que, para esses doadores de elétrons, a velocidade inicial de conversão de nitrato foi 69\% maior para o etanol do que para metanol. 
A velocidade de consumo de nitrato diminuiu $62 \%$ e $47 \%$, entre as fases B e C, para RE e RM1, respectivamente. As perdas observadas nas velocidades de conversão de nitrato acompanharam os decréscimos obtidos para as constantes cinéticas de primeira ordem $\left(\mathrm{k}_{1}\right)$ de consumo de nitrato, nesses reatores.

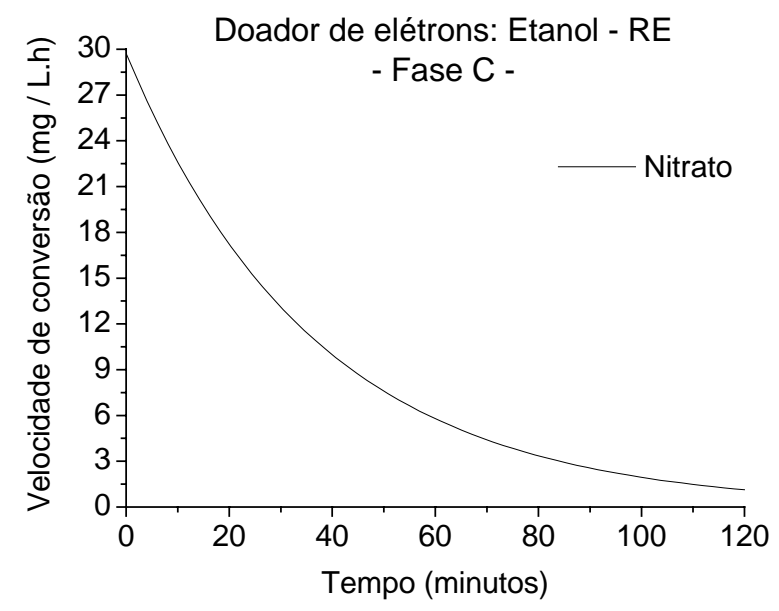

(a)

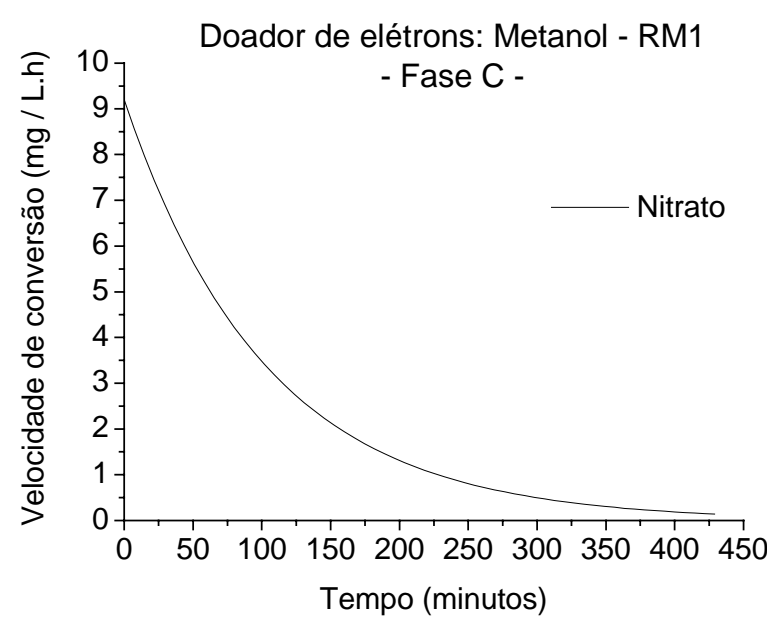

(b)

Figura 21. Velocidade de conversão de nitrato, na fase $C(C / N=0,75)$, para: (a) RE e (b) RM1

\subsubsection{Relação $C / N=0,5$ (Fase $D)$}

Nesta fase, apenas os reatores RE e RM1 foram mantidos em funcionamento, uma vez que a operação de RM2 foi encerrada na fase C.

A Figura 22 apresenta os dados referentes ao monitoramento dos parâmetros, nitrato e nitrito, durante os dois meses de operação do reator desnitrificante RM1. Os resultados obtidos durante o monitoramento do reator RE não serão apresentados, pois, de forma semelhante ao ocorrido, na fase C, as concentrações de nitrato e nitrito, presentes no efluente de todas as bateladas, mantiveram-se abaixo do limite de detecção do método utilizado para quantificação desses compostos.

Através da Figura 22, pôde-se concluir que os microrganismos consumidores de nitrito apresentaram melhora de desempenho no consumo de nitrito, ao longo dos dois meses de operação do reator RM1, para a relação C/N igual a 0,5. Devido à diminuição gradativa da concentração de nitrito no efluente desse reator, pode ser observado que, aparentemente, houve um processo de adaptação das bactérias redutoras de nitrito à utilização de fontes internas de carbono (endógenas), pois, como foi concluído através dos resultados das fases A e B, essa população já se encontrava adaptada ao metanol desde a primeira fase de operação (fase A). 
Doador de elétrons: Metanol - RM1

Relação $\mathrm{C} / \mathrm{N}=0,5$

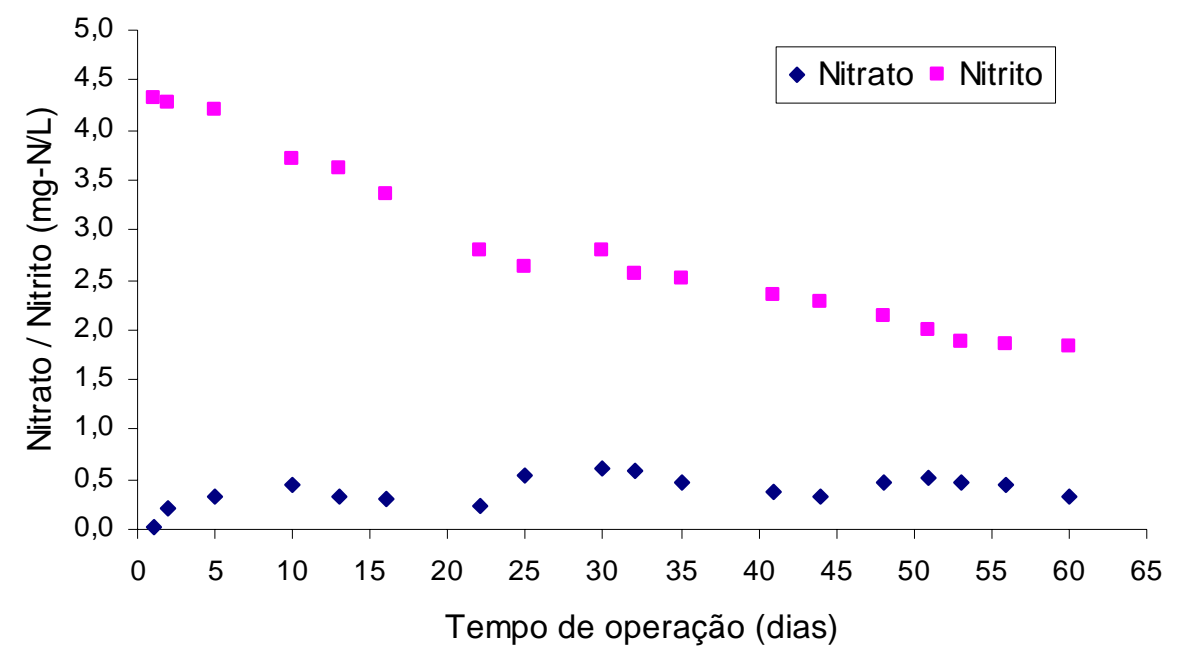

Figura 22. Concentrações de nitrato e nitrito, no efluente do reator $R M 1$ (relação $C / N=0,5$ ).

Mais uma vez, as concentrações de nitrogênio amoniacal, no efluente dos reatores RE e RM1, mantiveram-se próximas dos valores apresentados na fase C.

O resultado do monitoramento dos parâmetros $\mathrm{pH}$, alcalinidade e ácidos voláteis (Tabela 28) permitiu afirmar que os reatores mantiveram a estabilidade observada na fase anterior (fase $\mathrm{C}$ ), inclusive para o $\mathrm{pH}$, que foi, novamente, superior a 8,0.

Tabela 28. Resumo do monitoramento dos reatores RE e RM1, fase D.

\begin{tabular}{ccccccc}
\hline \multirow{2}{*}{ Parâmetro } & \multicolumn{5}{c}{ Doador de elétrons (C/N =0,5) } \\
\cline { 2 - 7 } & \multicolumn{3}{c}{ Etanol - RE } & \multicolumn{3}{c}{ Metanol - RM1 } \\
\cline { 2 - 6 } Mín. & Médio & Máx. & Mín. & Médio & Máx. \\
\hline $\begin{array}{c}\text { pH } \\
\text { Alcalinidade a } \\
\text { bicarbonato* }\end{array}$ & 8,00 & $8,20 \pm 0,09$ & 8,30 & 8,10 & $8,12 \pm 0,03$ & 8,17 \\
$\begin{array}{c}\text { (mg CaCO } / \mathrm{L}) \\
\text { Ácidos voláteis }\end{array}$ & 195 & $211 \pm 14$ & 228 & 205 & $209 \pm 10$ & 230 \\
$\begin{array}{c}\text { (mg Ác. Acético/L) } \\
\text { *- refere-se a alcalinidade total a bicarbonato presente no efluente dos reatores. }\end{array}$
\end{tabular}

Na Figura 23, são apresentados os perfis temporais de concentração de nitrato, nitrito, metanol e etanol, para a fase D, nos reatores RE e RM1. Os perfis foram realizados após dois meses de operação com a relação $\mathrm{C} / \mathrm{N}$ igual a 0,5.

Foi constatado, através da Figura 23a, que houve, realmente, desenvolvimento da população consumidora de nitrito que utiliza fontes internas de carbono, entre as 
fases $\mathrm{C}$ e $\mathrm{D}$, pois o acúmulo de nitrito, observado na fase C, não ocorreu na fase $\mathrm{D}$, tendo sido este composto, portanto, completamente consumido.

O desempenho dos reatores ficou ainda mais prejudicado com a diminuição da relação C/N para 0,5. No caso do reator RE, a desnitrificação foi completa após 565 minutos, na fase D, contra 240 minutos, da fase C, ou seja, aumento de, aproximadamente, $58 \%$ do tempo necessário para reduzir, completamente, nitrato e nitrito. Para o reator RM1, o aumento foi de 30\% (de 429 minutos, na fase C, para 619 minutos, na fase D). Comparando-se os valores obtidos nas fases D e B (50 minutos, para RE e 120 minutos, para RM1), as reduções nos valores foram muito relevantes, de 91\% e 81\%, para RE e RM1, respectivamente. Esses dados reforçam a grande necessidade da suplementação de sistemas desnitrificantes com fontes externas de carbono.

Apesar disso, o comportamento cinético, de reação primeira ordem (eq. 13) para consumo de nitrato, foi mantido, em ambos os reatores e, mais uma vez, não foi possível ajustar os dados experimentais de nitrito, em nenhum dos casos. O ajuste dos dados experimentais de consumo de metanol e etanol também foi realizado, mas os resultados não serão, novamente, discutidos devido à pequena quantidade de pontos experimentais. Os modelos que melhor representaram esses dados foram o de reação de ordem zero e o de primeira ordem, para consumo de etanol e de metanol, respectivamente.

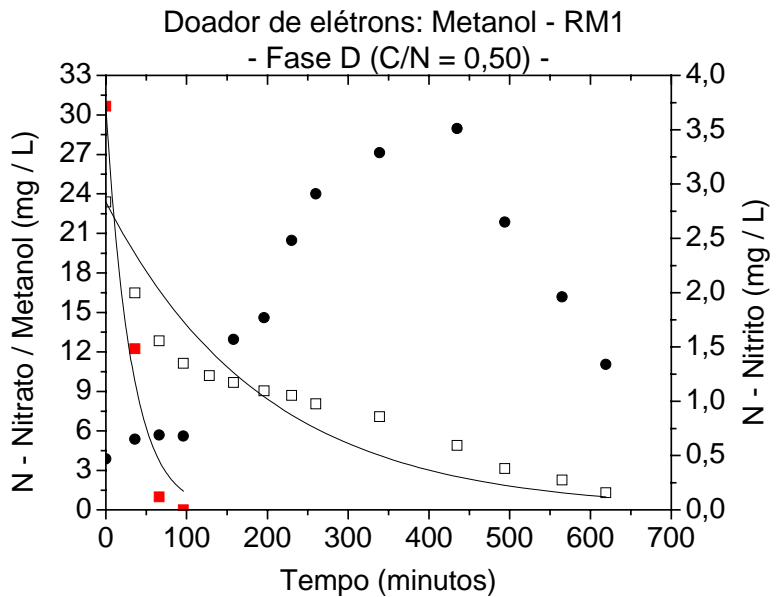

(a)

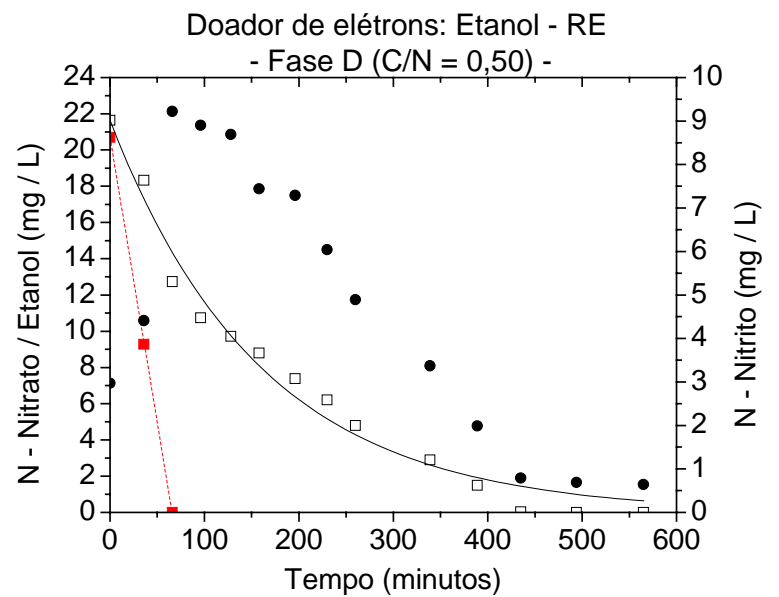

(b)

$\square \quad$ Dados experimentais de Nitrato $\quad$ Dados experimentais de Metanol / Etanol - Dados experimentais de Nitrito - - - Modelo cinético (eq. 12) Modelo cinético (eq. 13)

Figura 23. Perfis temporais de concentração de nitrato, nitrito, metanol e etanol, para a relação $\mathrm{C} / \mathrm{N}=$ 0,5 (fase D), nos reatores: (a) RM1 e (b) RE. 
No caso do etanol, por exemplo, tem-se apenas 3 pontos experimentais, o que tornou fácil o ajuste de reação ordem zero. Para se obterem parâmetros cinéticos confiáveis, seria necessário que a coleta dos dados de etanol e metanol tivessem sido realizadas em menores intervalos de tempo, a fim de gerar maior quantidade de dados experimentais.

O comportamento do nitrito, observado em RE, foi semelhante aos anteriormente descritos, tendo havido a rápida formação de nitrito, na presença de etanol e, em seguida, o seu consumo, que se desenvolveu lentamente.

A Tabela 29 apresenta as concentrações máximas de nitrito, obtidas nos perfis temporais de concentração de nitrito, nos reatores RM1 e RE, nas fases B, C e D. É possível observar que houve aumento das concentrações máximas nitrito, entre as fases B e C, mais acentuado para RE. Aparentemente, a população que utilizava fontes internas de carbono (endogenia) não se encontrava adaptada, ao final da fase B, devido à grande disponibilidade de fontes de carbono mais eficientes (metanol e etanol). Desse modo, essa população perdia a competição pelo nitrito na fase B.

Os valores mais elevados, observados na fase C, podem ser justificados pelo fato de os microrganismos que utilizam fontes de carbono mais eficientes, para reduzir o nitrito, já não terem essas fontes disponíveis, enquanto os utilizadores de fontes internas encontravam-se em fase de adaptação. Essa hipótese explica o fato de o consumo de nitrito ter sido mais lento do que nas fases anteriores, bem como terem sido detectadas concentrações mais elevadas deste composto.

Os microrganismos que utilizavam fontes internas de carbono para reduzir nitrito, na fase D, provavelmente tornaram-se mais adaptados e foram responsáveis pela pequena diminuição da concentração de nitrito, observada no valor máximo. Nas fases C e D, as concentrações máximas de nitrito, no reator RM1 (4,99 mg-N/L e 3,50 mg$\mathrm{N} / \mathrm{L}$, para as fases $\mathrm{C}$ e $\mathrm{D}$, respectivamente), foram inferiores às observadas no reator RE (11,47 mg-N/L e 9,22 mg-N/L, para as fases C e D, respectivamente), indicando que essa população se encontrava mais bem estabelecida em RM1.

Tabela 29. Concentrações máximas de nitrito observadas nos reatores alimentado com metanol e etanol, nas fases B, C e D.

\begin{tabular}{ccc} 
& \multicolumn{2}{c}{ alimentado com metanol e etanol, nas fases B, C e D. } \\
\cline { 2 - 3 } Fase & \multicolumn{2}{c}{ Concentração máxima de nitrito (mg-N/L) } \\
\cline { 2 - 3 } & Reator com etanol - RE & Reator com metanol - RM1 \\
\hline B & 2,62 & 1,09 \\
C & 11,47 & 4,99 \\
D & 9,22 & 3,50 \\
\hline
\end{tabular}


Os parâmetros cinéticos aparentes, obtidos para a relação $\mathrm{C} / \mathrm{N}$ igual 0,5 , são apresentados na Tabela 30, para RE e RM1.

A Figura 23 permite observar que os tempos gastos para consumir nitrato completamente foram iguais a 620 minutos e 560 minutos, para RM1 e RE, respectivamente, sendo, portanto, muito próximos. Os parâmetros cinéticos aparentes permitiram confirmar esta observação. Na fase $\mathrm{D}$, a constante cinética de primeira ordem $\left(\mathrm{k}_{1}\right)$, para consumo de nitrato, foi apenas 16\% maior em RE do que em RM1, contra $65 \%$, na fase C e $70 \%$, na fase B.

Tabela 30. Parâmetros cinéticos aparentes obtidos para a fase $D$, nos reatores alimentados com metanol e etanol.

\begin{tabular}{ccccc}
\hline \multirow{2}{*}{$\begin{array}{c}\text { Parâmetros cinéticos } \\
\text { aparentes }\end{array}$} & \multicolumn{3}{c}{ Doador de elétrons - Fase D (C/N = 0,5) } \\
\cline { 2 - 5 } & $\begin{array}{c}\text { Etanol } \\
(\text { eq. 12) }\end{array}$ & $\begin{array}{l}\text { Nitrato } \\
\text { (eq. 13) }\end{array}$ & $\begin{array}{c}\text { Metanol } \\
\text { (eq. 13) }\end{array}$ & $\begin{array}{c}\text { Nitrato } \\
\text { (eq. 13) }\end{array}$ \\
\cline { 2 - 5 } $\mathrm{k}_{1}\left(\mathrm{~h}^{-1}\right)$ & - & $0,37 \pm 0,02$ & $1,91 \pm 0,31$ & $0,31 \pm 0,03$ \\
$\mathrm{k}_{0}(\mathrm{mg} / \mathrm{L} . \mathrm{h})$ & $18,87 \pm 0,06$ & - & - & - \\
$\mathrm{R}^{2}$ para primeira ordem & - & 0,981 & 0,974 & 0,862 \\
$\mathrm{R}^{2}$ para ordem zero & 0,999 & - & - & - \\
\hline
\end{tabular}

A constante cinética de primeira ordem $\left(\mathrm{k}_{1}\right)$, obtida para os dados de nitrato, diminuiu consideravelmente entre as fases C e D. Na fase $D\left(k_{1}=0,37 h^{-1}\right.$, para RE e $k_{1}$ $=0,31 \mathrm{~h}^{-1}$, para RM1), essa constante foi aproximadamente 4 e 2 vezes menor do que na fase $C\left(k_{1}=1,64 \mathrm{~h}^{-1}\right.$, para $\mathrm{RE}$ e $\mathrm{k}_{1}=0,58 \mathrm{~h}^{-1}$, para RM1), para RE e RM1, respectivamente. Esses dados indicam que o reator $\mathrm{RE}$ foi mais sensível do que o reator RM1 à diminuição da relação $\mathrm{C} / \mathrm{N}$ para 0,5 .

Na Figura 24, são apresentadas as velocidades de consumo de nitrato, para RM1 e RE nas fases A, B, C e D, considerando que o modelo cinético de primeira ordem representou bem os dados experimentais. Todas as velocidades são apresentadas com o objetivo de se ter uma visão geral do comportamento dos reatores, desde o início da operação, considerando as alterações nutricionais a que foram expostos.

Em relação à fase anterior (fase $\mathrm{C}$ ), a velocidade inicial de conversão de nitrato diminuiu 73\% e 22\%, nos reatores RE e RM1, respectivamente, confirmando a grande sensibilidade do reator RE à mudança da relação $\mathrm{C} / \mathrm{N}$ para 0,5 .

Na fase $\mathrm{D}$, as velocidades de conversão de nitrato atingiram valores bem próximos entre si, nos reatores RM1 e RE. A velocidade inicial de consumo de nitrato foi $11 \%$ maior para RE do que para RM1, conforme era esperado, devido aos valores obtidos para as constantes cinéticas de primeira ordem $\left(\mathrm{k}_{1}\right)$, para redução de nitrato a 
nitrito. Portanto, o reator RE apresentou melhor desempenho do que o RM1, em todas as fases.

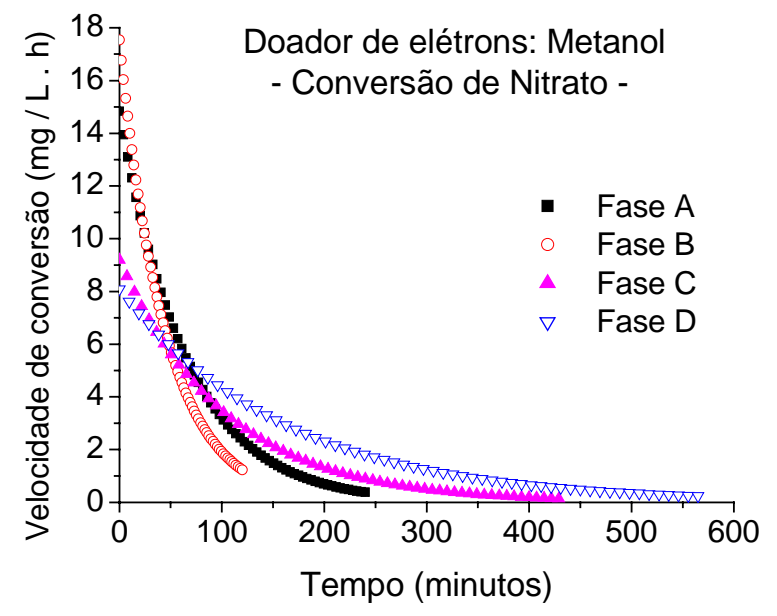

(a)

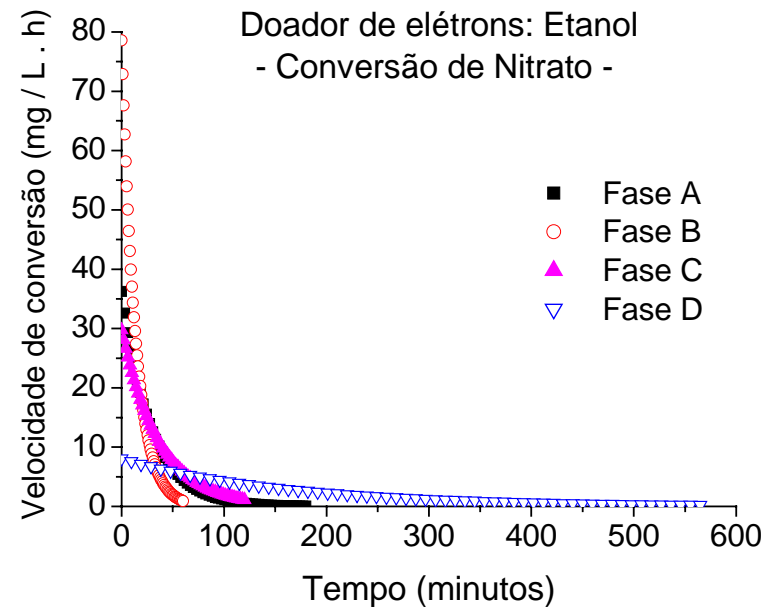

(b)

Figura 24. Velocidade de conversão de nitrato, nas fases A, B, C e D, para os doadores de elétrons: (a) Metanol e (b) Etanol.

Também é possível observar, na Figura 24, que as mudanças mais bruscas, observadas entre os valores de velocidades de conversão de nitrato, foram encontradas no reator RE, principalmente entre as fases B e C; e entre, C e D.

\subsubsection{Acompanhamento morfológico do lodo}

As amostras foram coletadas do lodo utilizado como inóculo e dos reatores, logo após a realização dos ensaios para obtenção dos parâmetros cinéticos, ou seja, no final das fases A, B e C (reatores RE, RM1 e RM2) e no final da fase D (reatores RE e RM1). Também são apresentados os principais bacilos encontrados nos ensaios de NMP, realizados no inóculo e na fase B de operação dos reatores. Tais amostras foram submetidas a análises de microscopia eletrônica de varredura, contraste de fase e fluorescência. Os resultados estão resumidos na Tabela 31. Para cada amostra, aproximadamente 20 campos foram fotografados, sendo que as morfologias consideradas mais importantes, observadas ao longo da operação dos reatores, estão ilustradas nas Figuras 26 e 27. A simbologia utilizada na Tabela 31 é indicativa das quantidades relativas das morfologias encontradas nos reatores: 
Tabela 31. Morfologias presentes nas amostras retiradas dos reatores e submetidas à microscopia de contraste de fase e fluorescência.

\begin{tabular}{|c|c|c|c|c|c|c|c|c|c|c|c|c|c|}
\hline \multirow{2}{*}{\multicolumn{2}{|c|}{$\begin{array}{c}\text { Semelhança das principais } \\
\text { morfologias encontradas }\end{array}$}} & \multirow[b]{2}{*}{ Inóculo } & \multicolumn{4}{|c|}{ Etanol } & \multicolumn{4}{|c|}{ Metanol } & \multicolumn{3}{|c|}{ Metano } \\
\hline & & & fase $\mathrm{A}$ & fase B & fase $\mathrm{C}$ & fase D & fase $A$ & fase $B$ & fase $\mathrm{C}$ & fase $D$ & fase $A$ & fase B & fase $\mathrm{C}$ \\
\hline \multirow{3}{*}{$\begin{array}{l}\text { Domínio } \\
\text { Archaea }\end{array}$} & Methanosaetha sp & +++ & +++ & +++ & ++ & ++ & +++ & ++ & ++ & ++ & +++ & +++ & ++ \\
\hline & Methanosarcina sp. & ++++ & +++ & +++ & +++ & +++ & +++ & +++ & +++ & +++ & +++ & +++ & ++ \\
\hline & B. Fluorescente & +++ & ++ & ++ & ++ & ++ & ++ & ++ & + & + & + & & \\
\hline \multirow{4}{*}{$\begin{array}{l}\text { Domínio } \\
\text { Bacteria }\end{array}$} & Filamentos & ++ & + & + & + & + & + & + & + & & + & ++ & + \\
\hline & Bacilos & ++ & +++ & +++ & +++ & ++++ & ++ & +++ & +++ & +++ & +++ & +++ & +++ \\
\hline & Coco-bacilos & ++ & ++ & + & + & + & ++ & + & + & + & ++ & + & + \\
\hline & Cocos & +++ & ++ & ++ & ++ & +++ & ++ & ++ & ++ & ++ & ++ & ++ & ++ \\
\hline
\end{tabular}

+ : morfologias raramente presentes,

++: morfologias presentes,

+++ : morfologias presentes freqüentemente e

++++ : morfologias predominantes. 
Comportamento semelhante foi observado, em todos os reatores, em relação à seleção dos microrganismos. O acompanhamento das morfologias presentes, no inóculo, permitiu observar que, nesse lodo, havia o predomínio de arqueas metanogênicas, devido à presença de microrganismos semelhantes à Methanosarcina e Methanosaeta e bacilos fluorescentes. Ao longo do tempo de operação, esse tipo de microorganismos permaneceu nos reatores. Contudo, as arqueas semelhantes a Methanosaeta apresentaram-se, a partir da fase B, com visível perda de material celular. De fato, a partir dessa fase, a morfologia de bacilos (Figuras 26e, 26f, 26g, 27d, 27e e 27f) passou a ser observada com maior freqüência nos reatores, enquanto que, nas fases C e D, essa morfologia predominava nos reatores.

Foi observado que a estrutura dos grânulos se tornou fraca, ao longo do tempo de operação, sendo que alguns grânulos se desestruturaram dentro dos reatores. Na Figura 26a é possível observar a superfície do grânulo do reator RM2, na fase C, a qual se apresenta, aparentemente, porosa e ausente de microrganismos, enquanto a Figura 26e apresenta a superfície de um grânulo do reator RE servindo como material suporte para aderência de microrganismos. Além disso, ocorreu a formação gradativa de lodo floculento, que formou fina camada sobre os grânulos. No reator RE, esse lodo floculento foi mais representativo que nos demais reatores. No lodo floculento, de todos os reatores, bacilos e cocos grandes representaram as morfologias predominantes (Figuras 26g e 27c e 27f), encontradas imersas em matriz de polímero, o que provocou dificuldade de visualização desses microrganismos através de microscopia óptica.

Nos reatores RM1 e RE, as arqueas, semelhantes a Methanosarcina, estiveram presentes, em quantidade significativa, durante todo o período de operação. No entanto, esses microrganismos apresentavam-se na forma de cistos, o que indica que o ambiente não se encontrava favorável ao seu desenvolvimento (Figuras 26a, 26b e 27b).

Durante a fase C de operação do reator RM2, a ocorrência de arqueas semelhantes a Methanosarcina foi menor em relação às fases anteriores (A e B); além disso, a fluorescência desses microrganismos também diminuiu. A diminuição dessa população, na fase $\mathrm{C}$, pode ter sido decorrente da falta do produto intermediário (metanol ou acetato), produzido por bactérias metanotróficas. Contudo, é importante afirmar que nenhum dos produtos intermediários, mais conhecidos por serem produzidos por metanotróficas (acetato, formiato e metanol), foi detectado por HPLC. 


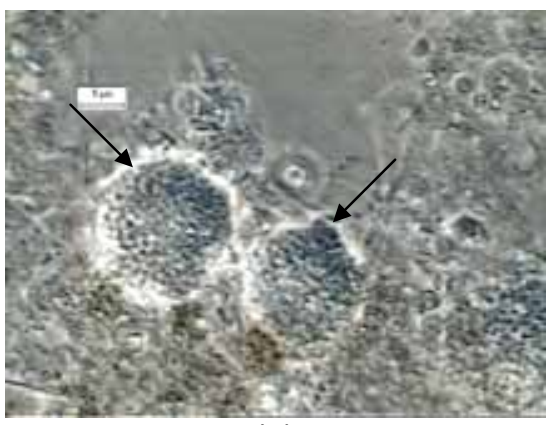

(a)

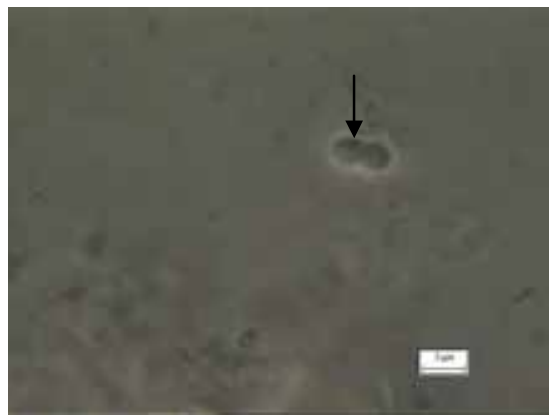

(d)

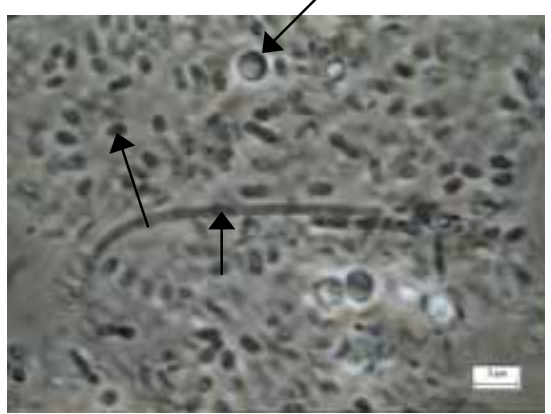

(g)

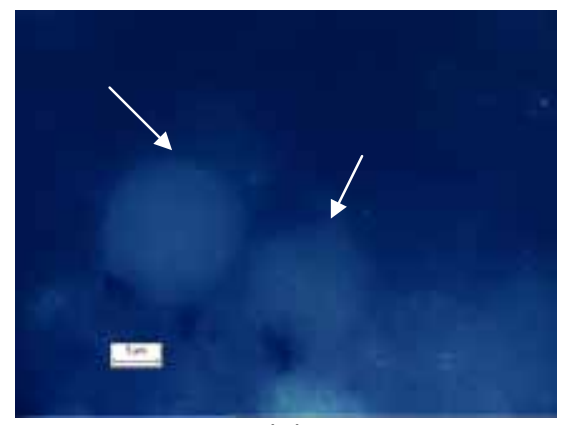

(b)

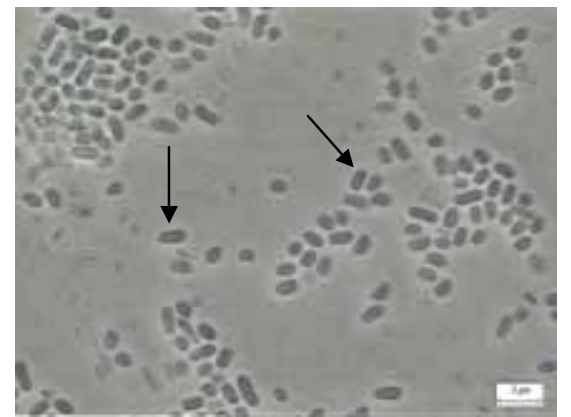

(e)

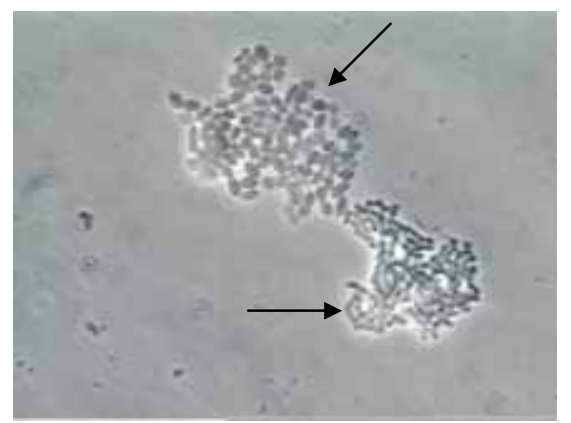

(h)

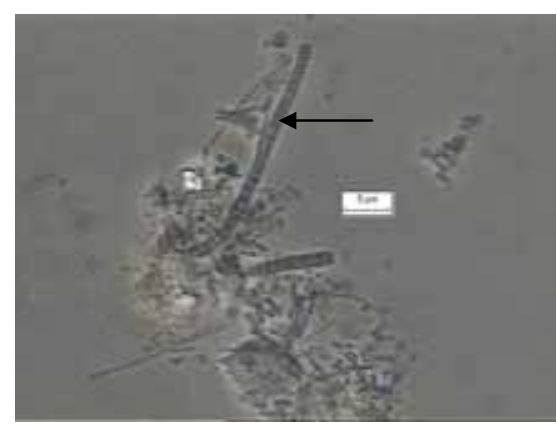

(c)

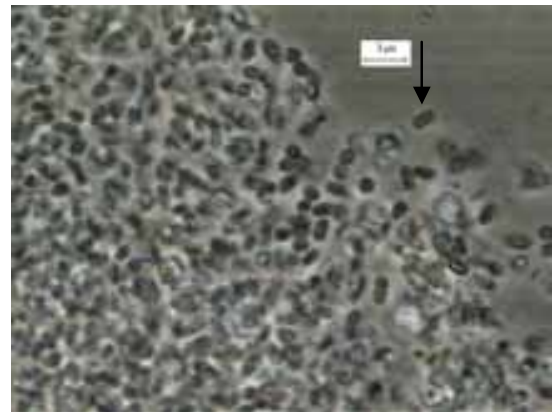

(f)

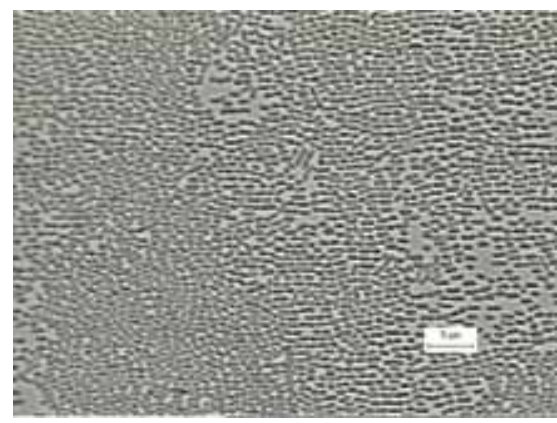

(i)

Figura 25. Principais morfologias observadas através de microscopia óptica comum e fluorescência: (a) Cistos de Methanosarcina observados no reator RM1 - Fase A; (b) Cistos fluorescentes de Methanosarcina, RM1 - FaseA; (c) Bactéria filamentosa observada em RE - Fase A; (d) Diplococo observado em RM2 - Fase B; (e) Bacilos encontrados no reator RM2 - Fase C; (f) Bacilos em matriz de polímero, observados em lodo floculento do reator RE - Fase D; (g) Bacilos, cocos e filamentos observados em RE - Fase C; (h) Bacilos afilados nas extremidades e bacilos na diluição $10^{-6}$ (NMP) do inóculo; (i) Bacilos na diluição $10^{-7}$ (NMP) do reator RE. 


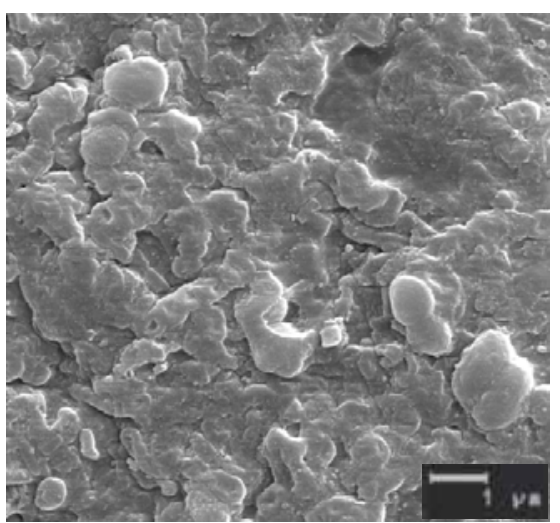

(a)

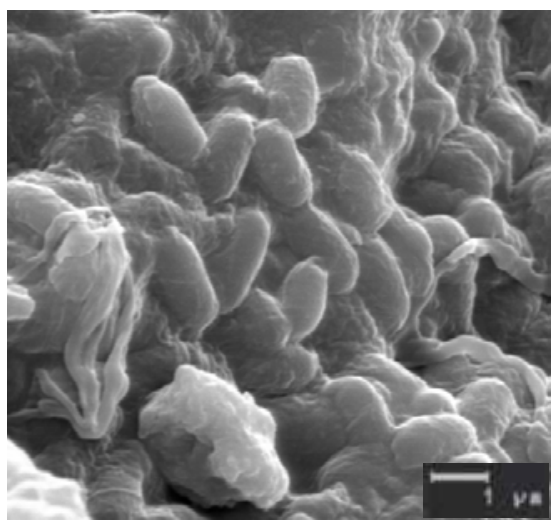

(d)

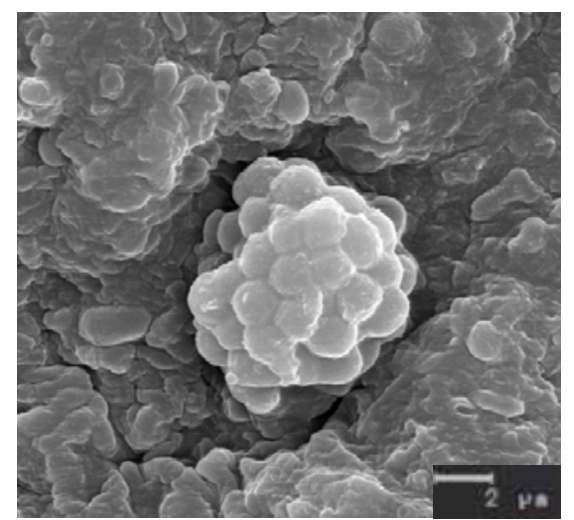

(b)

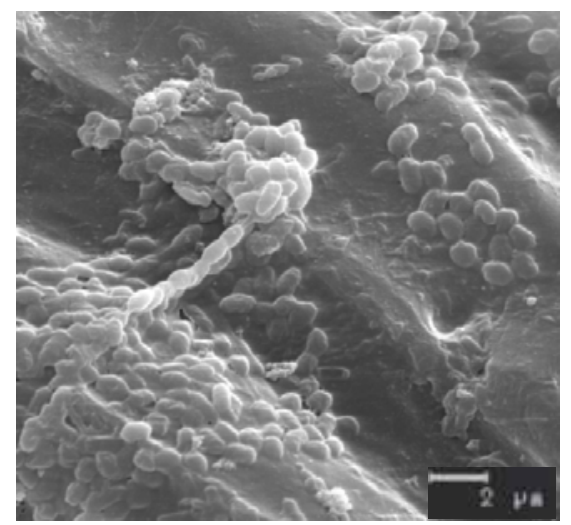

(e)

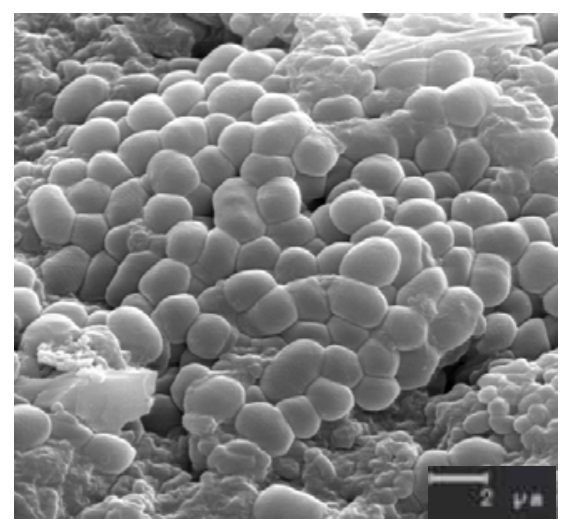

(c)

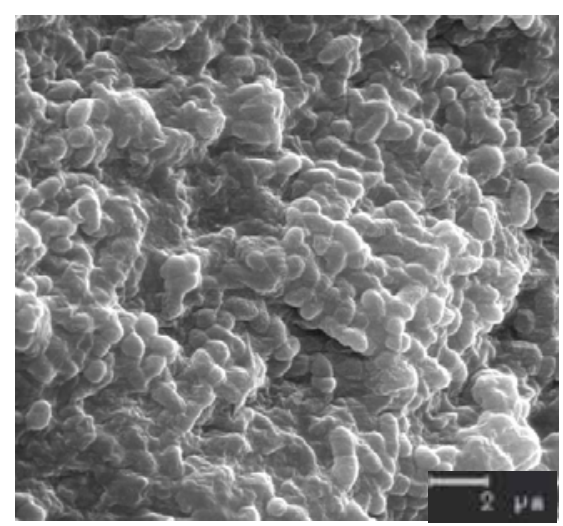

(f)

Figura 26. Morfologias observadas em microscopia eletrônica de varredura (MEV): (a) Superfície de grânulo do reator RM2 - Fase C; (b) morfologia semelhante à Methanosarcina em grânulo de RM1 - Fase B (c) Bacilos observados em RM2 - Fase A; (d) Bacilos em lodo floculento do reator RM1, recobertos por polímero - Fase D; (e) Bacilos na superfície do grânulo do reator RE - Fase D e (f) Bacilos na matriz de polímero do lodo floculento do reator RM2 - Fase C. 


\subsubsection{Análise da diversidade microbiana}

A avaliação e comparação da diversidade microbiana presente nos reatores desnitrificantes, foram realizadas por meio da técnica do PCR/DGGE.

Os resultados da extração de DNA e da amplificação dos fragmentos de DNA por PCR encontram-se apresentados nos géis de agarose no apêndice 10.

O perfil dos padrões das bandas no gel de DGGE dos fragmentos de DNAr 16S, amplificados com primer para o domínio Bacteria, estão apresentados nas Figuras 27, 30 e 31. Os fragmentos amplificados com primer, para o domínio Archaea, são apresentados nas Figuras 29 e 32. Nessas figuras, In, indica amostra representativa do lodo utilizado como inóculo; E, corresponde a amostra do reator alimentado com etanol (RE); M1, refere-se a amostra do reator com metanol (RM1); M2, indica amostra do reator com metano (RM2); $\mathrm{CP} 1$, refere-se ao controle positivo 1 ; $\mathrm{CP} 2$, refere-se ao controle positivo 2; e CN, corresponde ao controle negativo. As letras B, C e D indicam que as amostras são representativas das fases $B$ (relação $C / N=1,0$ - reatores RE e RM1 e operação do reator RM2, na presença de oxigênio), $C$ (relação $C / N=0,75$ - reatores RE e RM1) e D (relação C/N = 0,50 - RE e RM1), respectivamente. Os índices g e f, indicam amostras de lodo granular e lodo floculento, respectivamente.

A partir da fase C, como já mencionado, ocorreu a formação de lodo floculento sobre a camada de grânulos. A fim de se verificar possíveis diferenças entre as populações microbianas presentes nos grânulos e nos flocos dos reatores alimentados com etanol e metanol, nas fases C e D, foi realizada extração de DNA desse lodo.

As amostras de lodo, representativas do inóculo e das fases B, C e D, foram mantidas em freezer $\left(-20^{\circ} \mathrm{C}\right)$ por, aproximadamente, 1 ano e meio. Por esse motivo, talvez não se obteve sucesso na etapa de extração de DNA da amostra de lodo do reator alimentado com metano, na fase C. Observa-se (Figuras 27 e 29) que, na fase B, as amostras representativas desse reator já apresentavam, aparentemente, concentração celular inferior às demais, resultando em menor expressão das bandas desse reator quando comparada com as bandas dos reatores RE e RM1 (fase B). A presença de polímero na fase $C$ também pode ter interferido na extração do material genético da amostra do reator alimentado com metano.

É necessário considerar que a técnica de DGGE não fornece informações sobre a atividade dos microrganismos nos reatores; permite, apenas, inferir sobre a presença dos mesmos. 
Nas Figuras 27 e 29 as amostras foram dispostas no gel de maneira a permitir realizar comparação entre a diversidade de microrganismos presentes no inóculo e na fase B, dos reatores RE, RM1 e RM2. Por outro lado, as Figuras 30, 31 e 32 permitem observar as diferenças decorrentes da variação das relações C/N (fases B, C e D), nos reatores RE e RM1, e as diferenças impostas pelos doadores de elétrons etanol e metanol, para cada relação C/N.

Os resultados obtidos por meio da utilização da técnica de PCR/DGGE, para os reatores RE, RM1 e RM2, são resumidos no Tabela 32. As bandas, consideradas mais importantes, encontram-se relacionadas aos reatores e às fases em que estas ocorreram. As variações nutricionais impostas a cada reator, associadas aos resultados obtidos de consumo dos doadores de elétrons e redução dos aceptores de elétrons, tornaram possível, em alguns casos, destacar o provável grupo de microrganismo associado à banda em questão. 
Tabela 32. Resumo dos resultados obtidos por meio da utilização da técnica de PCR/DGGE.

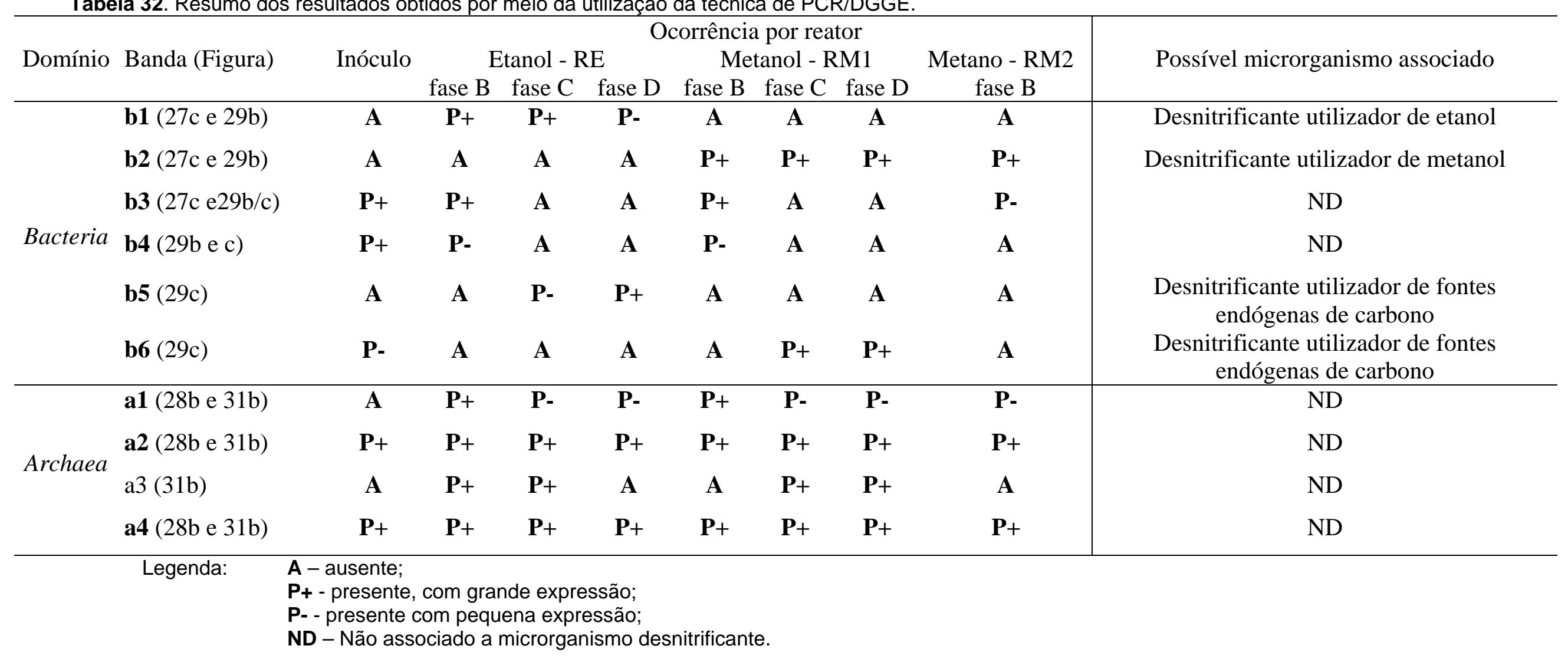


- Fase B (relação $\mathrm{C} / \mathrm{N}=1,0$ - reatores com etanol e metano e operação do reator alimentado com metano na presença de oxigênio)

A partir da Figura 27c, foi possível observar que a diversidade de microrganismos pertencentes ao domínio Bacteria, encontrada no inóculo, foi mantida na fase B (relação $\mathrm{C} / \mathrm{N}=1,0$ - reatores RE e RM1; operação do reator RM2 na presença de oxigênio). Apesar de a diversidade ter sido mantida, bandas com pouca expressão no inóculo, como as bandas $\boldsymbol{b} 1$ e $\boldsymbol{b} 2$ (Figura 27c), tornaram-se bastante expressivas na fase B dos reatores RE, RM1 e RM2, devendo estar relacionadas aos bacilos que, notadamente, se desenvolveram nesses reatores. Já a banda $\boldsymbol{b} 3$ manteve sua expressão na fase B dos reatores RE e RM1 e teve significância diminuída no reator RM2.

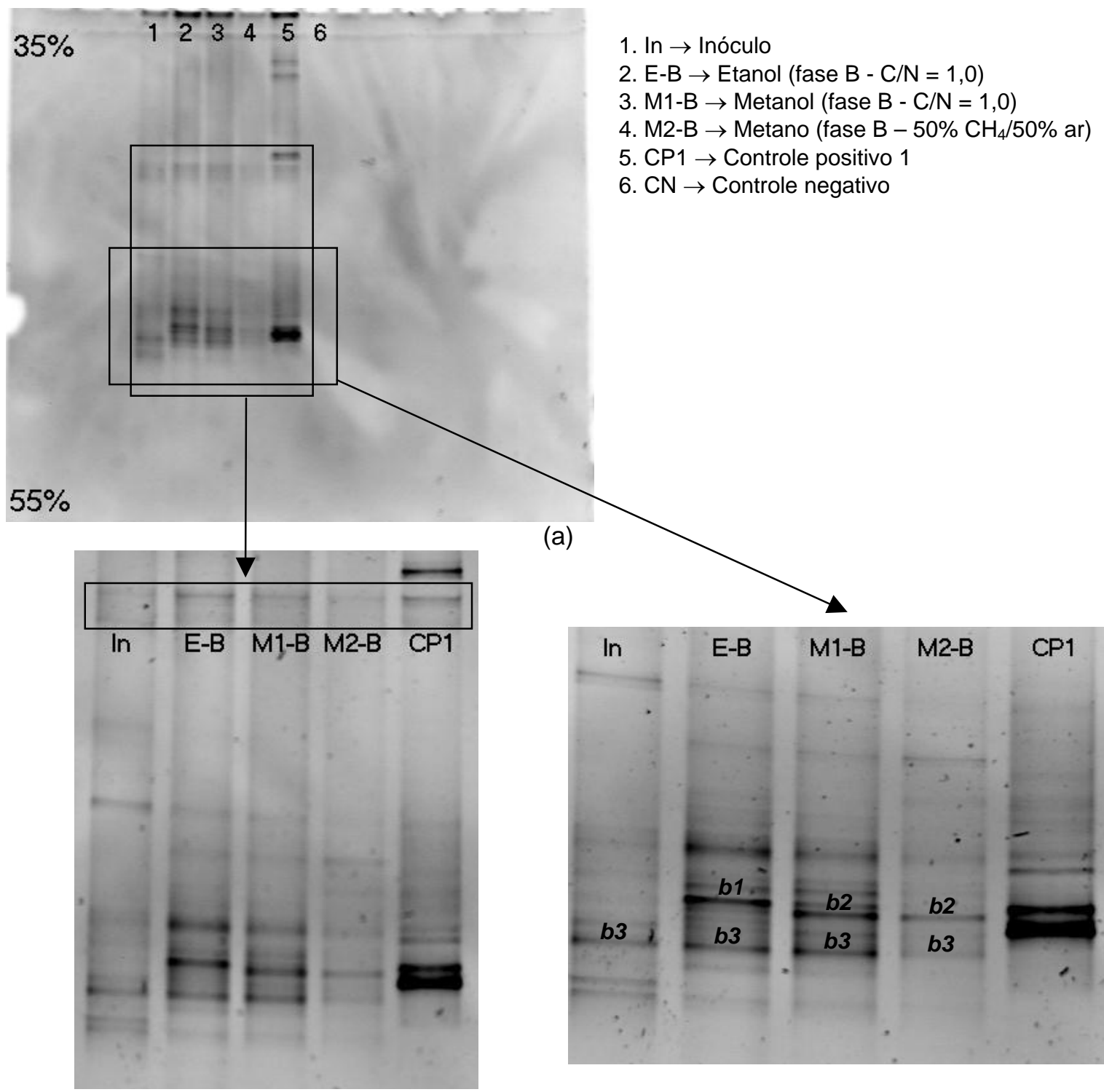

(b)

(c)

Figura 27 Diversidade de microrganismos pertencentes ao Domínio Bacteria nas amostras do inóculo (In) e dos reatores RE, RM1 e RM2, na fase B: (a) gel de DGGE; (b) e (c) ampliação da região do gel marcada em (a). 
A amostra utilizada como controle positivo (CP1 - Figura 27) foi proveniente de ensaio de purificação realizado com amostra de reator desnitrificante, alimentado com metano, metais e oxigênio (item 6.4), que cresceu na presença de nitrato. Em ensaio cinético, realizado com esta cultura purificada, constatou-se ser provável tratar-se de bactérias metanotróficas (ver item 6.6). É importante observar que as bandas do trecho em destaque (Figura 27b), presentes no inóculo e no controle positivo, encontravam-se presentes, também, nos reatores RE, RM1 e RM2.

Uma vez que não é possível garantir que os reatores encontravam-se sob condições de anaerobiose estrita, é possível que bactérias metanotróficas tenham se desenvolvido em todos os reatores, na fase B. Apesar de a composição do biogás não ter sido analisada após o nitrato ter sido completamente reduzido no meio líquido dos reatores RE e RM1, é provável que havia disponibilidade de metano, nesses reatores, devido à presença de arqueas metanogênicas durante todo o período de operação desses reatores.

A presença de bactérias metanotróficas, na fase B de todos os reatores, encontra-se justificada, principalmente nos reatores RE e RM1, pela utilização do gás metano produzido nos próprios reatores. Horz et al. (2002) detectaram, por meio da técnica de DGGE, que as populações de metanotróficas encontradas abaixo de $5 \mathrm{~cm}$ de solo, utilizaram o gás metano produzido por micro-sítios anaeróbios em solo fertilizado para pasto, enquanto que no presente trabalho, foi observado haver estratificação das morfologias presentes, em todos os reatores, ao longo da camada de lodo, sendo mais comum encontrar, na superfície, bacilos não fluorescentes e, no fundo dos reatores, Methanosarcina, Methanosaeta e bacilos fluorescentes.

É importante observar que a banda $\boldsymbol{b} 2$ foi bastante expressiva nos reatores RM1 e RM2, podendo ser indicativa da presença de microrganismos desnitrificantes utilizadores de metanol, principal composto produzido por bactérias metanotróficas. Esse composto deve ter sido utilizado como fonte de carbono para a desnitrificação no reator com metano.

A diversidade de bactérias (Figura 27c) foi muito semelhante entre os reatores RE e RM1, na fase B, tendo, a maior diferença, sido observada entre as bandas $\boldsymbol{b} \mathbf{1}$ e $\boldsymbol{b} 2$, devendo a incidência de tais bandas estar relacionada à presença de microrganismos desnitrificantes utilizadores de etanol e metanol, respectivamente. Apesar de as bandas do reator RM2 terem sido menos expressivas, constata-se (Figura 27c) que a diversidade de microrganismos pertencentes ao domínio Bacteria foi tão significativa, nesse reator, quanto nos reatores RE e RM1. 
A predominância de bacilos, no final da operação dos reatores, pôde ser confirmada devido ao significante desenvolvimento de microrganismos pertencentes ao domínio Bacteria, que ocorreu em todos os reatores, constatado através da comparação entre a diversidade microbiana presente no inóculo e na fase B dos reatores RE, RM1 e RM2 (Fig. 27c).

Em relação ao domínio Archaea (Figura 28), a diversidade de microrganismos encontrada no inóculo foi mantida, na fase B, de todos os reatores. De fato, já havia sido constatado, por meio de análises por microscopia óptica, a presença de arqueas metanogênicas durante a fase B de operação de todos os reatores. Além disso, a banda a1 (Figura 28b), praticamente sem expressão no inóculo, se desenvolveu em todos os reatores, apresentando maior significância nos reatores RE e RM1.

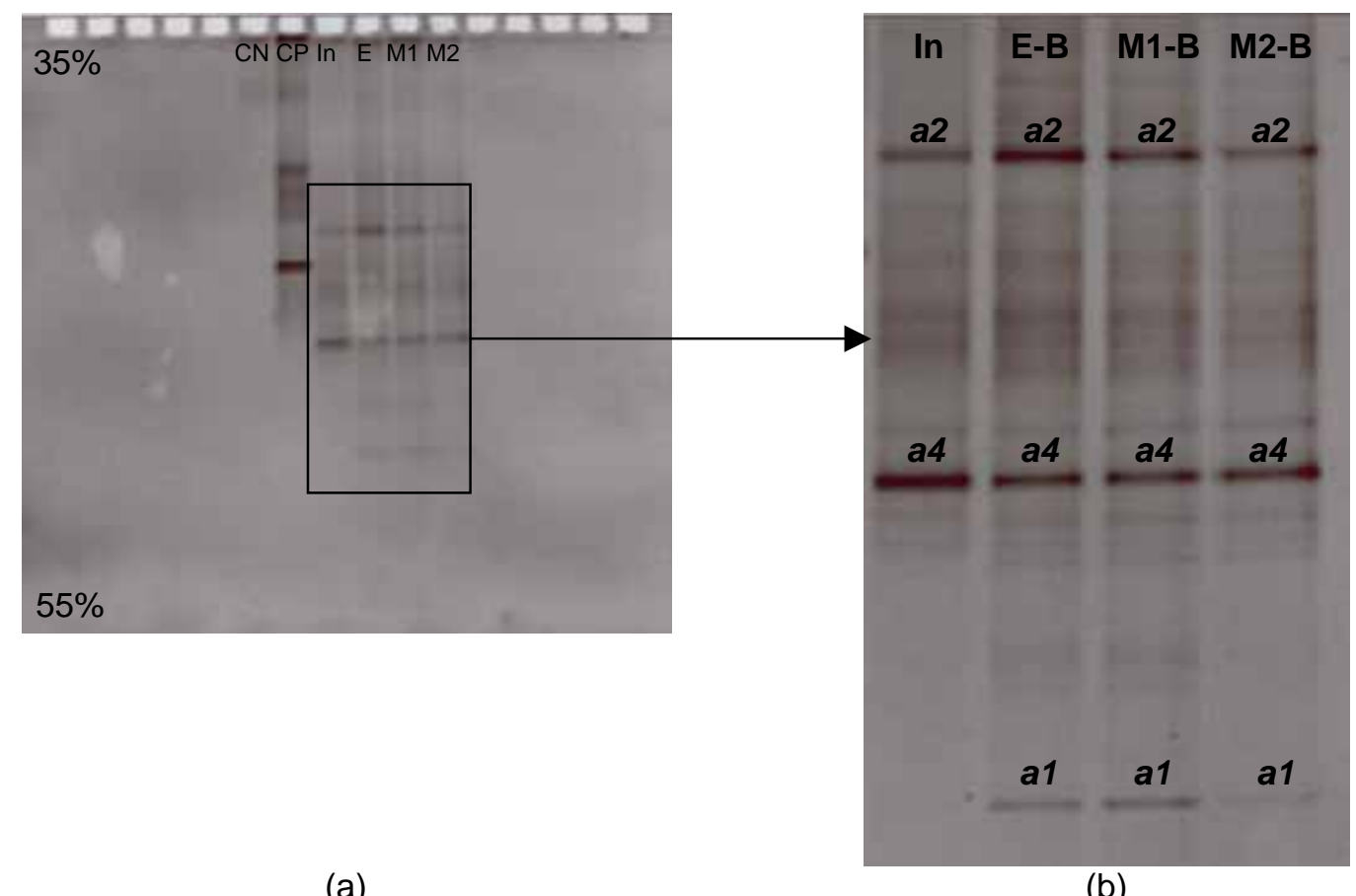

Figura 28. Diversidade de microrganismos pertencentes ao Domínio Archaea nas amostras do inóculo (In) e dos reatores RE, RM1 e RM2, na fase B: (a) gel de DGGE; (b) ampliação da região do gel marcada em (a).

Após o completo desaparecimento de nitrato do meio líquido, o que ocorreu após 50, 120 e 385 minutos, respectivamente, para os reatores RE, RM1 e RM2, o potencial redox tornou-se mais favorável ao desenvolvimento de arqueas metanogênicas. A manutenção e desenvolvimento dessas populações devem estar relacionados com o tempo de ciclo de batelada remanescente. 
- Fases B, C e D (comparação entre as populações de bactérias impostas pelas relações $\mathrm{C} / \mathrm{N}$ - reatores com etanol e metanol)

\section{- $\quad$ Reator com Etanol (RE) - Domínio Bacteria (Figura 29c)}

Observa-se que houve grande diversidade de bactérias durante todo o período de operação do reator RE. Destaque-se a presença da banda b1, praticamente sem expressão no inóculo e na fase $\mathrm{D}(\mathrm{C} / \mathrm{N}=0,5)$, e bastante expressiva nas fases $\mathrm{B}(\mathrm{C} / \mathrm{N}=1,0)$ e $\mathrm{C}(\mathrm{C} / \mathrm{N}$ $=0,75)$. As bandas $\boldsymbol{b} 3$ e $\boldsymbol{b} 4$, expressivas no inóculo e na fase $\mathrm{B}$, foram selecionadas do reator a partir da fase $\mathrm{C}$. Na fase $\mathrm{D}(\mathrm{C} / \mathrm{N}=0,5)$, é notável o aparecimento de bandas diferentes, que, praticamente, não apareciam nas fases B e C, merecendo destaque a banda b5. É muito provável que essa banda esteja relacionada ao desenvolvimento significativo de microrganismos desnitrificantes utilizadores de fontes internas (endógenas) de carbono.

No reator RE, o doador de elétrons, etanol, e o aceptor, nitrato, foram completamente removidos do meio líquido após, aproximadamente, 30 minutos e 125 minutos, na fase $\mathrm{C}$ (Figura 21c - $\mathrm{C} / \mathrm{N}=0,75$ ) e após 60 minutos e 440 minutos, na fase D (Figura 24b - C/N = 0,50), respectivamente. Diante disso, fontes endógenas de carbono foram utilizadas, após o consumo completo de etanol, para reduzir o nitrato remanescente. Dessa forma, encontra-se justificada a seleção de algumas bandas (b1, b3 e b4 - Figura 29c), entre as fases B e C, e o surgimento de outras (b5 - Figura 29c). As bandas selecionadas devem estar relacionadas a microrganismos desnitrificantes utilizadores de etanol, enquanto que as bandas que surgiram são indicativas do desenvolvimento bactérias desnitrificantes utilizadoras de fontes internas de carbono.

O desaparecimento de algumas bandas não implica a afirmativa de que os microrganismos correspondentes tornaram-se ausentes do reator, mas sim que sua concentração celular tornou-se pouco significativa, quando comparada com a de microrganismos relacionados a outras bandas que se desenvolveram no reator (por exemplo, a banda $\boldsymbol{b} 5$ - Figura 29c).

É importante constatar que o lodo floculento (Figura 29c), que se desenvolveu no reator RE, apresentou a mesma diversidade bacteriana do lodo granular, utilizado para inocular esse reator, sendo que as bandas observadas no lodo floculento foram significantemente mais expressivas do que as observadas nos grânulos. Isto indica que a concentração desses microrganismos era maior no floco do que nos grânulos. Tal constatação, aliada ao fato de que os grânulos se desestruturaram ao longo do tempo de operação do reator, permitiu concluir pela vantagem da utilização de suportes para 
imobilização da biomassa desnitrificante, quando o etanol é utilizado como doador de elétrons.
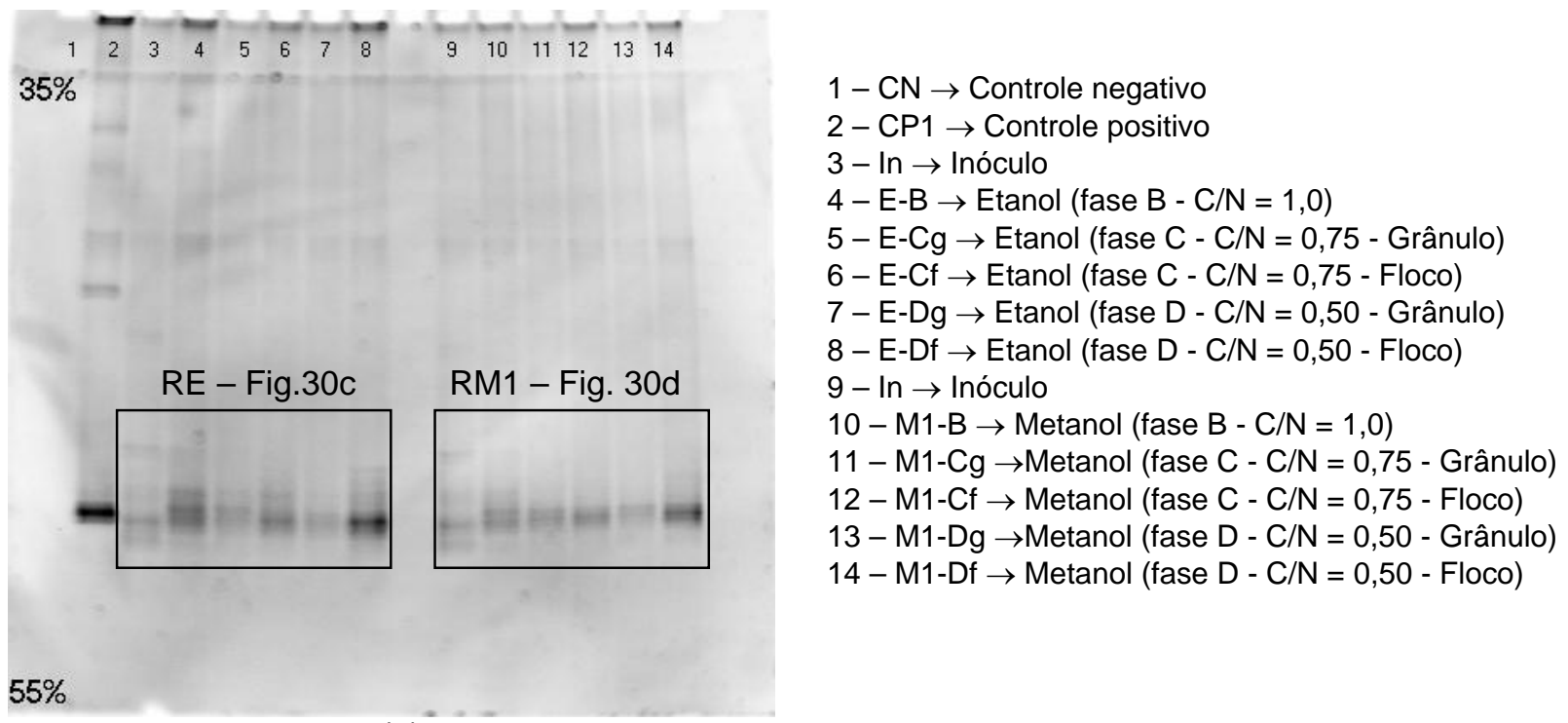

(a)

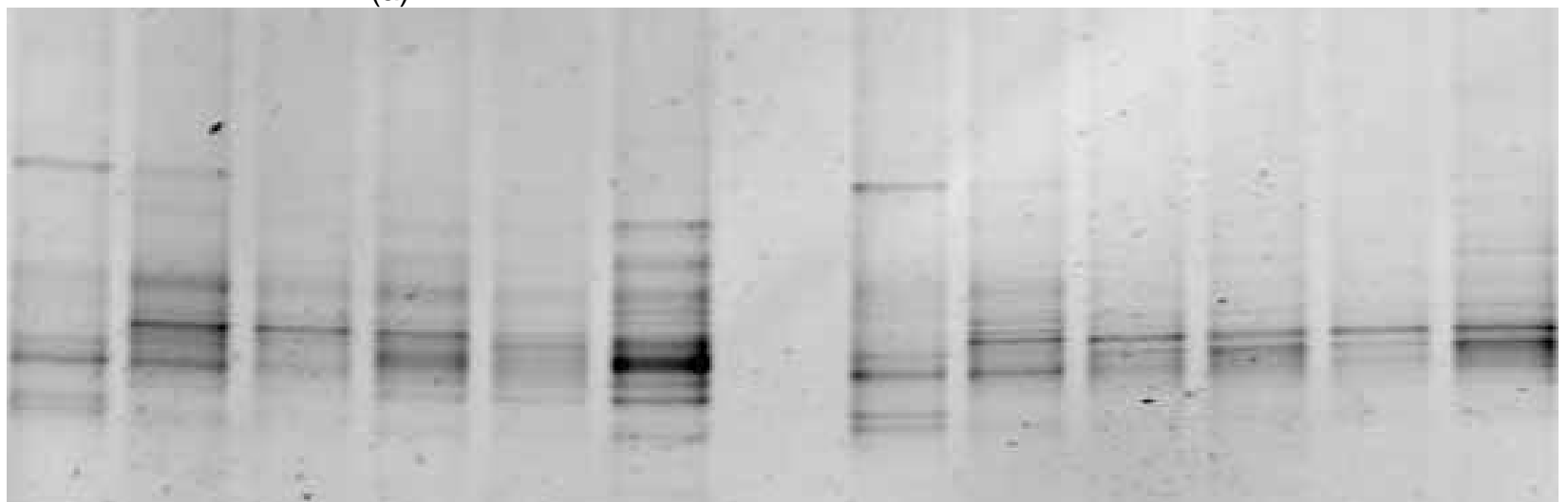

(b)

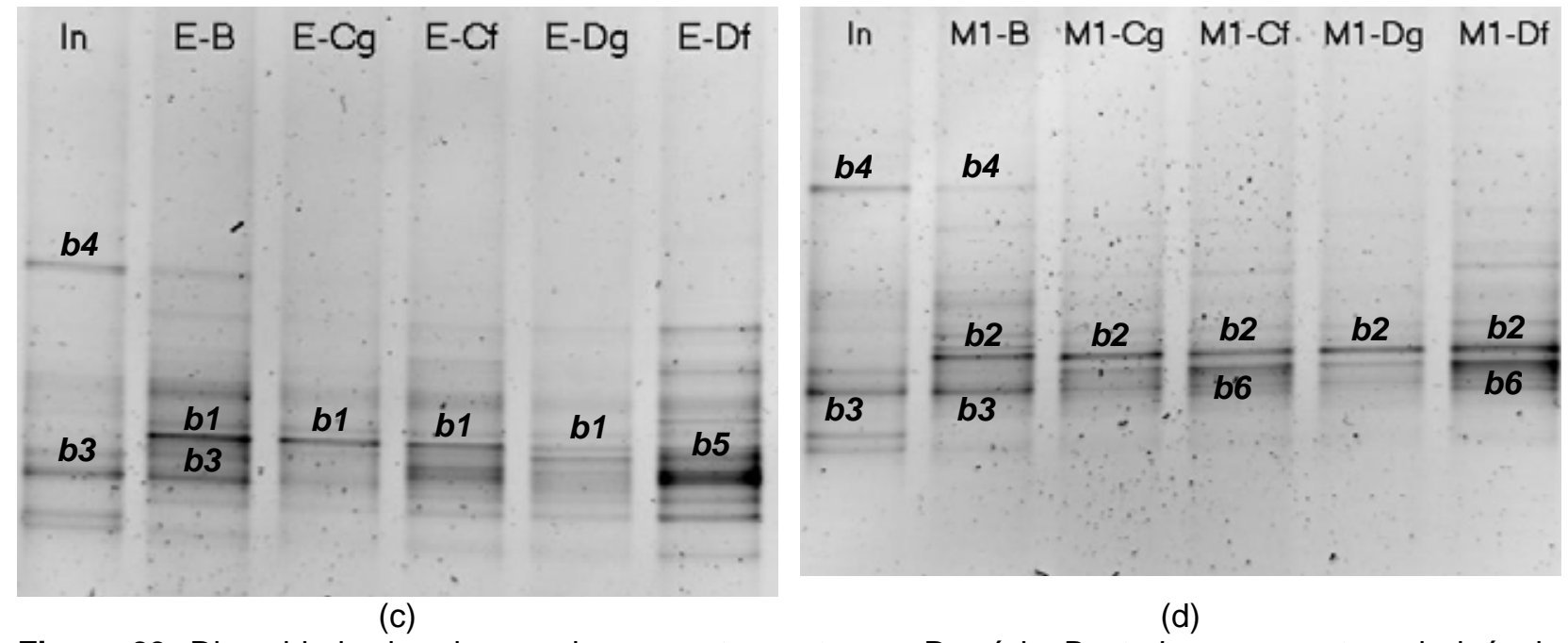

Figura 29. Diversidade de microrganismos pertencentes ao Domínio Bacteria nas amostras do inóculo (In) e dos reatores E e M1, nas fases B, C e D: (a) gel de DGGE; (b) ampliação da região do gel contendo as amostras dos reatores RE e RM1 (c) região do gel para RE e (d). região do gel para RE 


\section{- $\quad$ Reator com Metanol (RM1) - Domínio Bacteria (Figura 29d)}

Os fatos observados, em relação à diversidade de bactérias no reator com metanol, foram muito semelhantes aos observados no reator com etanol. As bandas b4 e b3 (Figura 29d) foram menos expressivas a partir da fase $C(C / N=0,75)$ e a banda $\boldsymbol{b} 6$ (Figura 29d) apareceu nas fases C e D, sendo mais expressivas no lodo floculento do que no lodo granular. No entanto, a banda b2 (Figura 29d) manteve-se praticamente estável, ao longo de todo o período de operação, sendo que essa banda não apresentou expressão no inóculo.

Dessa forma, a banda b2 (Figura 29d) deve estar relacionadas à presença de microrganismo desnitrificante utilizador de metanol, enquanto que a banda b6 (Figura 29d) está relacionada, provavelmente, aos microrganismos utilizadores de fontes endógenas de carbono.

As bandas do lodo floculento foram mais expressivas que as do lodo granular, sendo tal diferença mais significante na fase $\mathrm{D}(\mathrm{C} / \mathrm{N}=0,5$ - Figura 29d).

No reator RM1, ficou evidente, a partir dos gráficos de consumo de nitrito (Figuras 21a e 24a), que, entre as fases C e D, houve o desenvolvimento de microrganismos consumidores de nitrito que utilizaram fontes internas de carbono. Enquanto na fase C houve acúmulo de nitrito, pôde-se observar que ocorreu sua completa redução na fase D, após o metanol ter sido completamente consumido. É possível que a banda b6 (Figura 29d), que apresentou maior desenvolvimento entre as fases C e D, esteja relacionada a esta população de microrganismos.

- Fases B, C e D (comparação entre as populações de bactérias imposta pelos doadores de elétrons etanol e metanol, para as diferentes relações $\mathrm{C} / \mathrm{N}$ )

\section{- Domínio Bacteria (Figura 30)}

É possível observar (Figura 30b - comparação entre E-B e M1-B) que as bandas do reator RE foram mais expressivas do que as do reator RM1. Além disso, o lodo floculento do reator RE (Figura 30c - colunas E-Cf; M1-Cf; E-Df e M1-Df) apresentou maior diversidade de microrganismos pertencentes ao Domínio Bacteria do que o do reator RM1. Esses resultados reforçam a afirmativa de que o etanol foi doador de elétrons mais eficiente que o metanol. Aparentemente, a seleção de bactérias dos grânulos foi mais intensa no reator RE (Figuras 30b e 30c - colunas E-Cg; M1-Cg; E-Dg e M1-Dg), o qual apresentou maior formação de lodo floculento. 


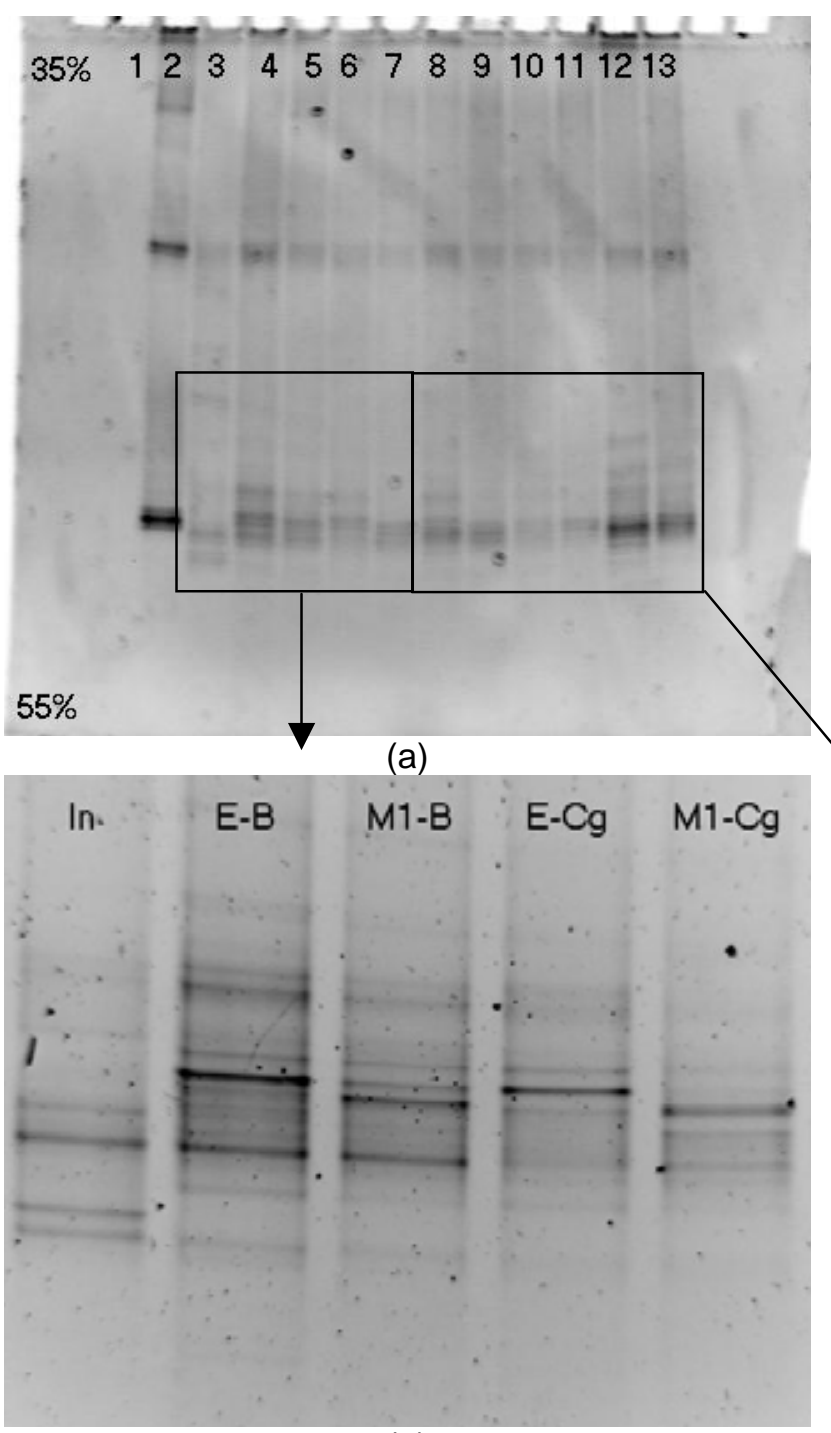

(b)
1 - $\mathrm{CN} \rightarrow$ Controle negativo

2 - CP1 $\rightarrow$ Controle positivo 1

3 - In $\rightarrow$ Inóculo

4 - E-B $\rightarrow$ Etanol (fase $B-C / N=1,0$ )

5 - M1-B $\rightarrow$ Metanol (fase $B-C / N=1,0$ )

6 - E-Cg $\rightarrow$ Etanol (fase $\mathrm{C}-\mathrm{C} / \mathrm{N}=0,75$ - Grânulo)

7 - M1-Cg $\rightarrow$ Metanol (fase $C$ - $C / N=0,75$ - Grânulo)

8 - E-Cf $\rightarrow$ Etanol (fase $\mathrm{C}-\mathrm{C} / \mathrm{N}=0,75$ - Floco)

9 - M1-Cf $\rightarrow$ Metanol (fase $\mathrm{C}-\mathrm{C} / \mathrm{N}=0,75$ - Floco)

10 - E-Dg $\rightarrow$ Etanol (fase D - C/N = 0,50 - Grânulo)

11 - M1-Dg $\rightarrow$ Metanol (fase $D$ - C/N = 0,50 - Grânulo)

12 - E-Df $\rightarrow$ Etanol (fase D - C/N = 0,50 - Floco)

$13-\mathrm{M} 1-\mathrm{Df} \rightarrow$ Metanol (fase $\mathrm{D}-\mathrm{C} / \mathrm{N}=0,50-$ Floco)

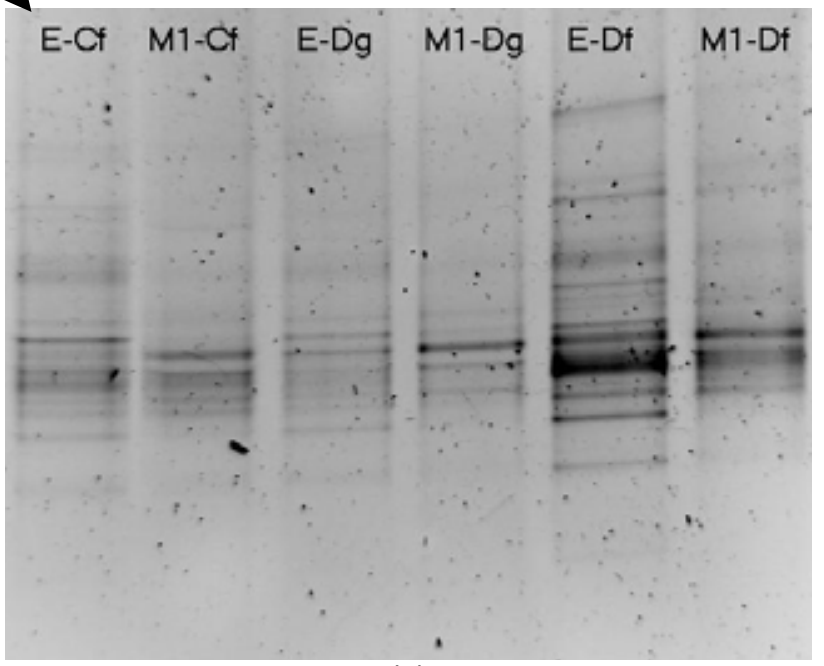

(c)

Figura 30. Diversidade de microrganismos pertencentes ao Domínio Bacteria nas amostras do inóculo (In) e dos reatores RE e RM1, nas fases B, C e D: (a) gel de DGGE; (b) e (c) ampliação da região do gel marcada em (a).

- Fases B, C e D (Domínio Archaea - comparação entre as populações dos reatores com etanol e metanol)

Para comparação dos lodos, referente à presença de microrganismos pertencentes ao Domínio Archaea, foi utilizada apenas a Figura 31, devido à semelhança observada entre os reatores RE e RM1, não sendo necessário separar comparações em função das relações $\mathrm{C} / \mathrm{N}$ e dos doadores de elétrons. 


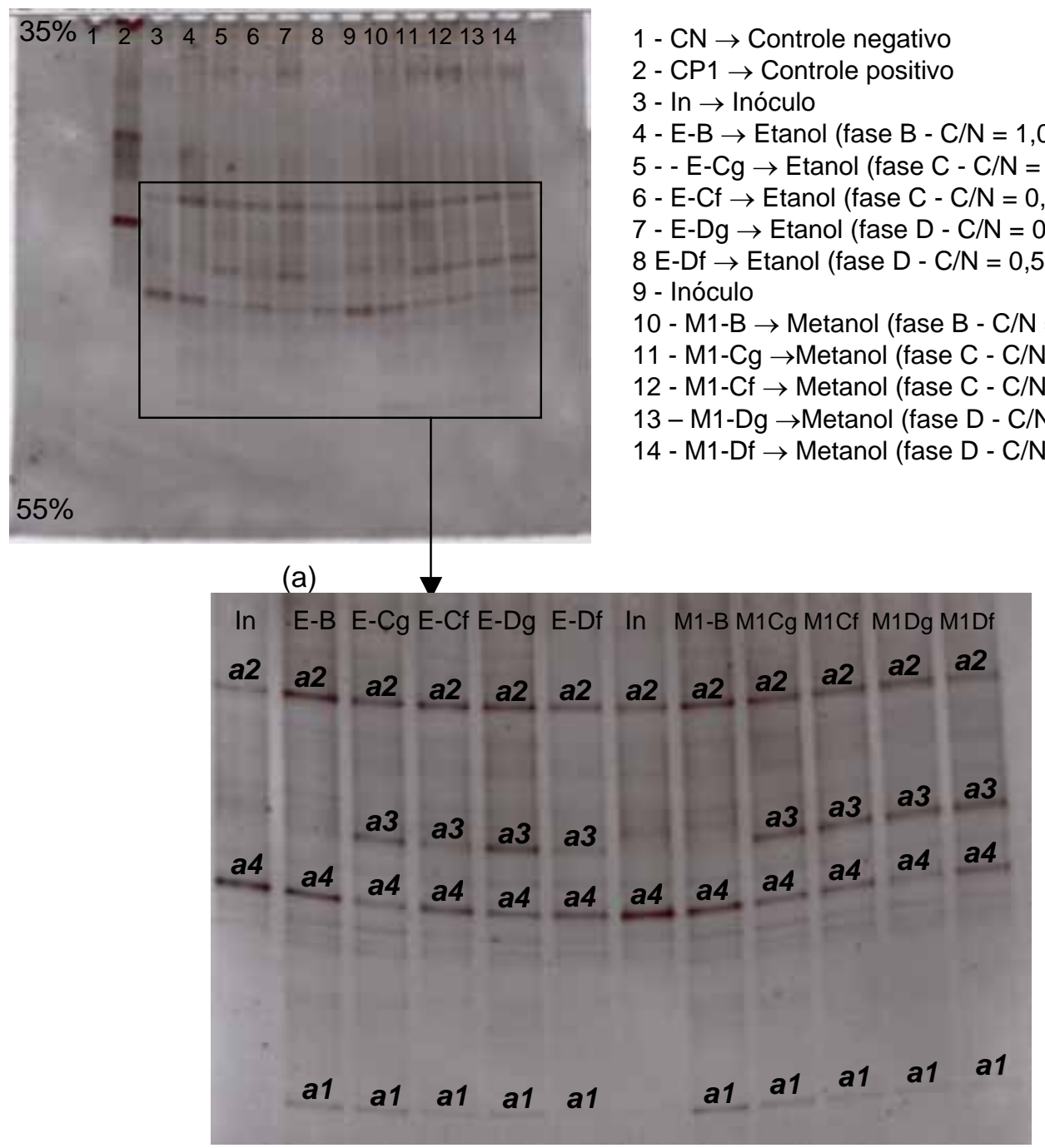

(b)

Figura 31. Diversidade de microrganismos pertencentes ao Domínio Archaea nas amostras do inóculo (In) e dos reatores RE e RM1, nas fases B, C e D: (a) gel de DGGE; (b) ampliação da região do gel marcada em (a).

Foi constatado que não houve diferenças entre as populações de arqueas nos reatores RE e RM1 (Figura 31b); ou seja, os microrganismos pertencentes ao Domínio Archaea não foram selecionados pela fonte de carbono utilizada. Além disso, a diversidade de arqueas foi, praticamente, a mesma entre RE e RM1.

No entanto, foi clara a ocorrência de processo de seleção de arqueas decorrente das variações nas relações $\mathrm{C} / \mathrm{N}$. A banda $\boldsymbol{a}$, inexpressiva no inóculo e na fase $\mathrm{B}(\mathrm{C} / \mathrm{N}=1,0)$ dos reatores, apresentou desenvolvimento significativo a partir da fase $C(C / N=0,75)$, estando presente nas fases C e D, tanto no lodo floculento quanto nos grânulos, de ambos os reatores. Processo semelhante foi observado em relação à banda $\boldsymbol{a 1}$, sendo que esta apresentou maior expressão no início da operação dos reatores (Fase $\mathrm{B}-\mathrm{C} / \mathrm{N}=1,0$ ), tendo 
sua significância progressivamente reduzida com a diminuição da relação C/N para 0,75 e 0,5, nos reatores RE e RM1.

Nesse caso, seria natural afirmar que a banda $\boldsymbol{a} \mathbf{1}$ estaria relacionada à presença microrganismos utilizadores de etanol e metanol, uma vez que esta foi sendo selecionada do meio com a diminuição da relação $\mathrm{C} / \mathrm{N}$, enquanto a banda $\boldsymbol{a} 3$ deveria estar relacionada com microrganismos utilizadores de fontes endógenas de carbono e energia, por esta ter se desenvolvido com as mudanças das relações C/N. No entanto, a segunda afirmação tornase muito difícil quando se refere a arqueas metanogênicas, que, em geral, utilizam os produtos das fases de acidogênese e acetogênese, além de hidrogênio e dióxido de carbono para produção de metano.

Diante disso, a associação dos resultados obtidos a partir das análises de redução de nitrato e de nitrito com os obtidos por meio da técnica de DGGE e os decorrentes das observações morfológicas, permitiram inferir que, um aparente equilíbrio deve ter sido alcançado em todos os reatores entre as populações de bactérias desnitrificantes, bactérias metanotróficas e arqueas metanogênicas, devendo ser estes os principais grupos de microrganismos presentes nos reatores. Metanol e acetato, substrato para Methanosarcina e Methanosaeta são produzidos por bactérias metanotróficas, enquanto o processo de desnitrificação gera $\mathrm{CO}_{2}$. As condições de nutrição de cada grupo de microrganismo deve ter sido satisfeita através desse equilíbrio.

Observa-se que as bandas $\boldsymbol{a} \mathbf{2}$ e $\boldsymbol{a 4}$, presentes no inóculo, permaneceram nos reatores RE e RM1, durante todo o período de operação (Figura 31b). Essas bandas foram bastante expressivas em ambos os reatores e podem estar relacionadas à presença dos microrganismos semelhantes a Methanosaeta e Methanosarcina, que foram observados durante todo o período de operação dos reatores.

O processo de seleção dos microrganismos dos grânulos para formação de lodo floculento, intensamente detectado no Domínio Bacteria, não foi observado em relação aos microrganismos pertencentes ao Domínio Archaea.

\subsection{Experimentos com reatores para estudo cinético}

A utilização desses reatores visou à obtenção de perfis temporais de concentração de nitrato e de nitrito, que permitissem a determinação de parâmetros cinéticos intrínsecos de desnitrificação quando metanol, etanol e metano foram utilizados como doadores de elétrons. 
Para comparação entre os resultados obtidos com os reatores, para o estudo cinético, com os obtidos durante a operação dos reatores anóxicos comparativos (RE, RM1 e RM2), foi necessário calcular a relação F/M, mantida em cada reator. Para o cálculo dessa relação, F foi considerado ser a concentração de nitrato presente no meio líquido e M, a concentração de biomassa, medida como STV. A Tabela 33 apresenta as relações, determinadas no final da fase $\mathrm{B}$, para ambos os tipos de reatores.

É importante observar que, nos experimentos realizados com os reatores para estudo cinético, cada reator reapresentou um ponto experimental. Por esse motivo, os valores apresentados na Tabela 33 representam a média dos valores obtidos em cada reator.

Tabela 33. Relação F/M calculadas para a fase B, dos reatores RM1, RE e RM2.

\begin{tabular}{cccc}
\hline \multirow{2}{*}{ Condição } & \multicolumn{3}{c}{ Relação F/M para cada doador de elétrons (mg N-NO $\left.{ }_{3}{ }^{-} / \mathrm{g} \mathrm{STV}\right)$} \\
\cline { 2 - 4 } & Metanol (C/N =1,0) & Etanol $(\mathrm{C} / \mathrm{N}=1,0)$ & Metano $\left(50 \% \mathrm{CH}_{4} / 50 \%\right.$ ar) \\
\hline $\begin{array}{c}\text { Reatores anóxicos de } \\
\text { 4 L (fase B) }\end{array}$ & 1,031 & 1,960 & 1,779 \\
$\begin{array}{c}\text { Reatores para estudo } \\
\text { cinético (fase B) }\end{array}$ & 1,517 & 1,642 & 2,075 \\
\hline
\end{tabular}

As relações F/M, observadas nos reatores para estudo cinético, foram superiores às mantidas nos reatores anóxicos comparativos. Portanto, a quantidade de microrganismos, presente nesses reatores, foi menor que em RE, RM1 e RM2, exceto para os reatores do estudo cinético alimentados com etanol. Nesses, a relação F/M foi 16\% inferior; ou seja, nesse caso, a quantidade de microrganismos presente nos reatores para estudo cinético foi maior que em RE.

A resistência à transferência externa de massa na fase líquida, anteriormente investigada por Vieira (1996), para biomassa imobilizada na forma de grânulos, foi minimizada através da aplicação de velocidade de agitação, à mesa rotativa incubadora (“shaker”), igual a 250 rpm.

A velocidade de $250 \mathrm{rpm}$, utilizada nos primeiros ensaios, com lodo proveniente dos reatores RE, RM1 e RM2 (fase B), foi responsável pela quebra dos grânulos, de forma que, no final dos experimentos, a estrutura granular havia sido completamente desfeita. Por esse motivo, os ensaios foram novamente realizados, submetendo os reatores à velocidade de agitação de 200rpm, velocidade esta que, de acordo com Vieira (1996), também minimiza a resistência externa à transferência de massa. 
Após essa modificação, os grânulos continuaram a se desfazer, mas em menor proporção. Na Figura 32, estão apresentados os perfis temporais de concentração de nitrato, nitrito, $\mathrm{N}_{2} \mathrm{O}$, metanol e etanol obtidos com o lodo representativo da fase $\mathrm{B}$, dos reatores RE, RM1 e RM2.

As linhas contínuas apresentadas na Figura 32 não representam ajuste de modelo cinético. São, apenas, linhas de tendência, que ligam os dados experimentais.

Nos ensaios com lodo dos reatores RM1 e RE (Figuras 33a e 33b), a desnitrificação foi completa após 160 e 50 minutos, respectivamente, enquanto que, para o lodo proveniente de RM2, a desnitrificação não foi completa, mesmo após 10h de experimento. Em relação aos resultados obtidos para a fase B, nos reatores RE, RM1 e (Figuras 16a e 16b), o tempo despendido foi, aproximadamente, 25\% e 10\% maior nos reatores para estudo cinético, para os doadores de elétrons metanol e etanol, respectivamente. Como a resistência à transferência externa de massa foi minimizada, era esperado que houvesse redução no tempo necessário para a desnitrificação, principalmente no ensaio com o lodo de RE, que apresentou menor relação F/M.

O caso mais difícil de compreender foi o que ocorreu no ensaio com o lodo do RM2, em que, após 10h, ainda havia, no sistema, $12 \mathrm{mg}-\mathrm{N} / \mathrm{L}$ na forma dos óxidos de nitrogênio, nitrato e nitrito; ou seja, apenas 31\% do $\mathrm{N}_{-} \mathrm{NO}_{3}{ }^{-}$havia sido reduzido. No reator RM2, na fase B (Figura 16c), a desnitrificação foi completa após 385 minutos (6,42 h), tempo significativamente inferior ao decorrido no experimento com o lodo proveniente deste reator.

Diante disso, tornou-se difícil compreender os processos que ocorreram nos experimentos com lodo proveniente dos reatores RE, RM1 e RM2. Como a resistência externa à transferência de massa foi minimizada, é possível que a conformação desfeita dos grânulos tenha interferido no desempenho dos microrganismos. Além disso, a retirada de parte do lodo dos reatores, da condição em que se encontravam havia quatro meses, e a brusca submissão desses microrganismos à velocidade de agitação de 200 rpm, certamente teve grande influência sobre o comportamento final do processo de desnitrificação, devendo ter sido deletéria para alguns microrganismos.

Ainda assim, pretendia-se determinar os parâmetros cinéticos intrínsecos para os reatores RE e RM1. Outros testes foram realizados utilizando apenas o lodo floculento, presente nesses reatores, mas a desnitrificação não foi completa em nenhum dos casos. 


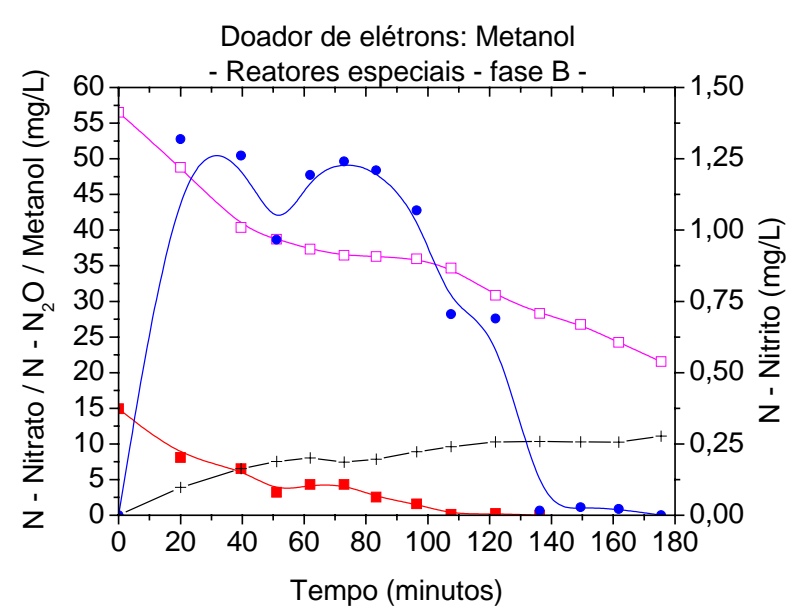

(a)

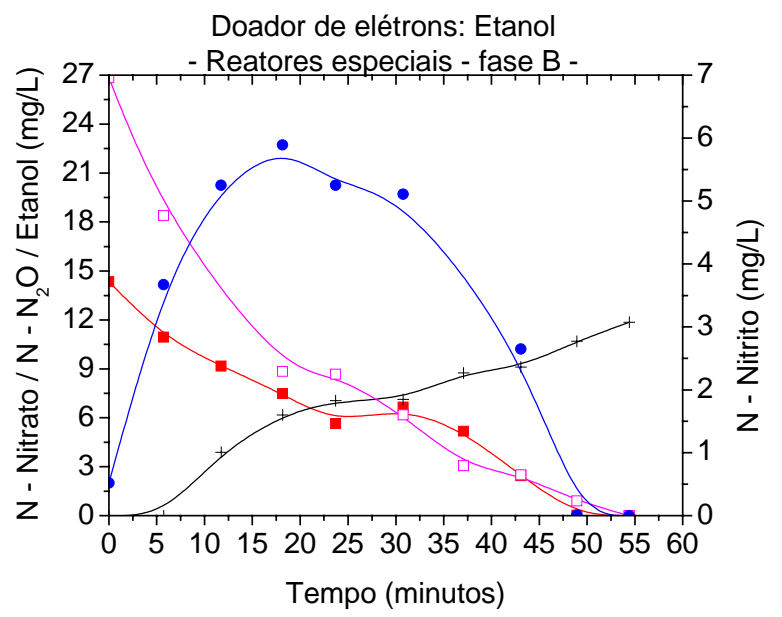

(b)

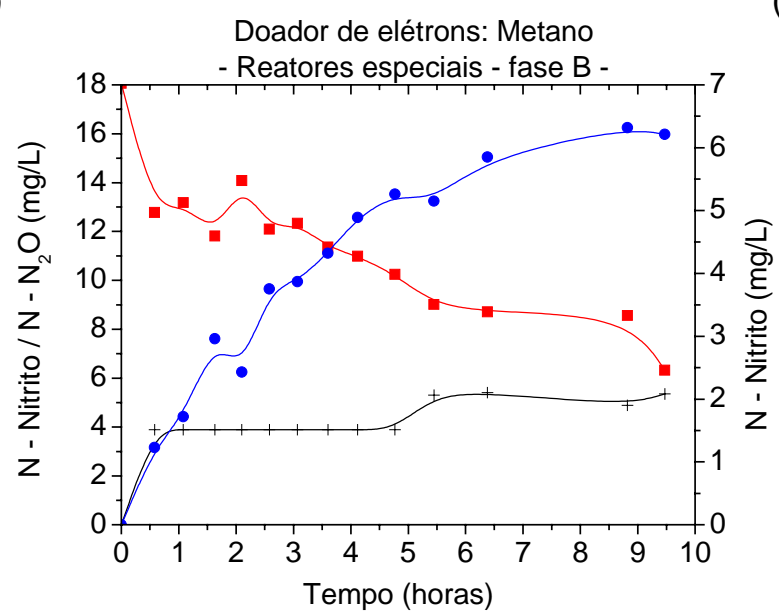

(c)

Dados experimentais de: $\square$ Nitrato $\longrightarrow \mathrm{N}_{2} \mathrm{O} \longrightarrow$ Metanol/Etanol $\longrightarrow$ Nitrito

Figura 32. Perfis temporais de concentração de nitrato, nitrito, $\mathrm{N}_{2} \mathrm{O}$, metanol e etanol obtidos, para a fase $B$, nos reatores para estudo cinético alimentados com: (a) metanol $(C / N=0,75) ;(b)$ etanol $(C / N=$ $0,75)$ e (c) metano (50\% $\mathrm{CH}_{4} / 50 \%$ ar).

Na fase C (relação C/N igual a 0,75), foi realizado apenas experimento com lodo proveniente de RE. Os resultados obtidos encontram-se apresentados na Figura 33. Neste experimento, os grânulos foram completamente desfeitos e o comportamento do processo de desnitrificação divergiu significativamente do esperado.

De acordo com os perfis de concentrações de nitrato e de nitrito, obtidos para o RE (Figura 21c), para a relação $\mathrm{C} / \mathrm{N}$ igual a 0,75, a desnitrificação foi completa após 240 minutos e o nitrato foi completamente consumido após 120 minutos. No experimento para obtenção de parâmetros cinéticos intrínsecos, após 30 minutos, o nitrato foi reduzido para nitrito, que não foi reduzido. As concentrações atingidas foram próximas de $12 \mathrm{mg}-\mathrm{N} / \mathrm{L}$ para o nitrato e $10 \mathrm{mg}-\mathrm{N} / \mathrm{L}$ para o nitrito. Após 300 minutos de experimento, as concentrações desses compostos se mantiveram praticamente estáveis, diferindo bastante do comportamento observado no RE (Figura 21c). 


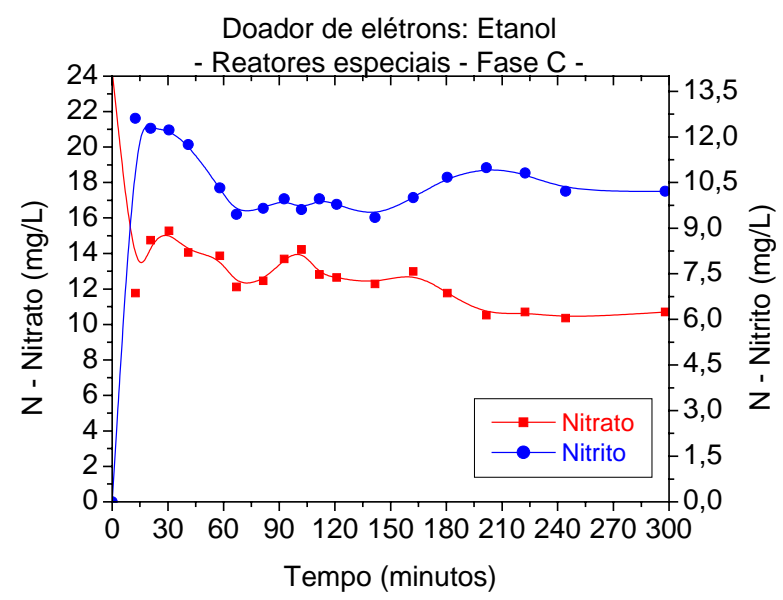

Figura 33. Perfil temporal de concentração de nitrato e nitrito obtidos, para a fase $C$, no reator especial alimentado com etanol.

Em vista dos resultados obtidos para o experimento com etanol, na fase C, os experimentos para obtenção de parâmetros cinéticos intrínsecos foram finalizados, não tendo sido realizados os experimentos com lodo proveniente dos outros dois reatores, metanol e metano. Fatores como a desgranulação do lodo e mudanças bruscas das condições físicas às quais os microrganismos encontravam-se adaptados (elevada velocidade de agitação - 200rpm), devem ter tido grande influência sobre o comportamento dos microrganismos desnitrificantes.

A desgranulação do lodo não permitiu determinar o raio médio dos grânulos presentes nos reatores. Tal parâmetro deveria ser utilizado para calcular o módulo de Thiele observado, a fim de se verificar se a resistência interna à transferência de massa teria sido minimizada. Estas indefinições não permitiram que os parâmetros cinéticos intrínsecos fossem determinados. No entanto, este ensaio permitiu verificar que os microrganismos desnitrificantes, presentes nos reatores RE, RM1 e RM2, encontravam-se muito bem adaptados às suas condições de funcionamento, indicando que os parâmetros cinéticos aparentes obtidos nas fases A, B, C e D são bastante confiáveis.

\subsection{Experimentos com reatores anóxicos alimentados com metano}

A Figura 34 apresenta os perfis temporais de concentração de nitrato, nitrito e $\mathrm{N}_{2} \mathrm{O}$ obtidos nos cinco reatores. Constatou-se produção de $\mathrm{N}_{2} \mathrm{O}$, nos reatores $\mathrm{M}, \mathrm{MO}$ e $\mathrm{C}$, confirmando, portanto, a ocorrência do processo de desnitrificação com formação de $\mathrm{N}_{2}$. Os reatores $\mathrm{M}$, MO e C foram denominados desnitrificantes pelo fato de terem convertido $63 \%, 67 \%$ e $68 \%$, respectivamente, do $\mathrm{N}$-nitrato afluente a $\mathrm{N}_{2} \mathrm{O}$. Acredita-se que, por se 
tratar de um gás, o procedimento adotado subestima a quantidade total de $\mathrm{N}_{2} \mathrm{O}$ produzido. Por outro lado, parte do nitrato pode ter sido convertido a $\mathrm{N}$-amoniacal, conforme já observado por outros autores (GUYNOT et al., 1998).

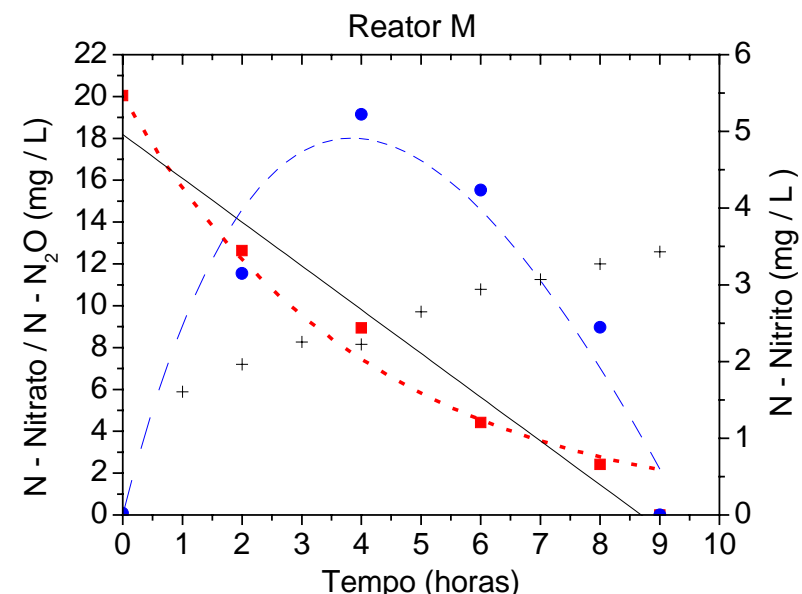

(a)

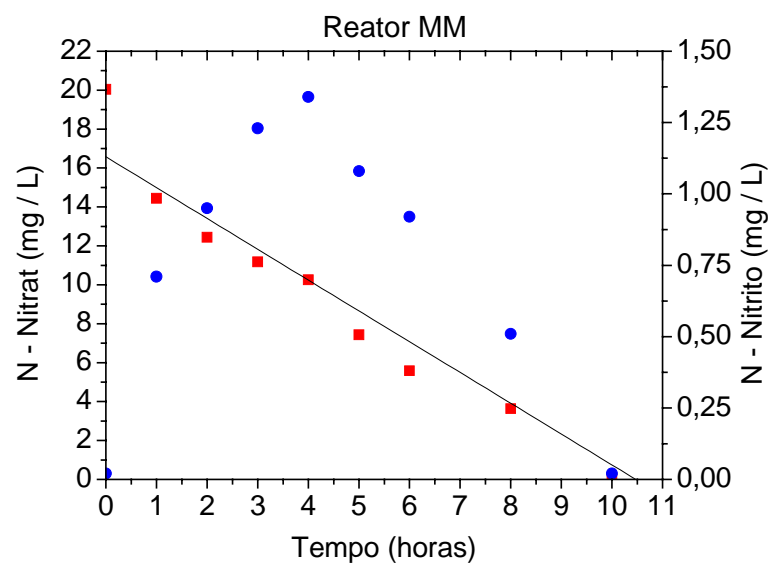

(c)

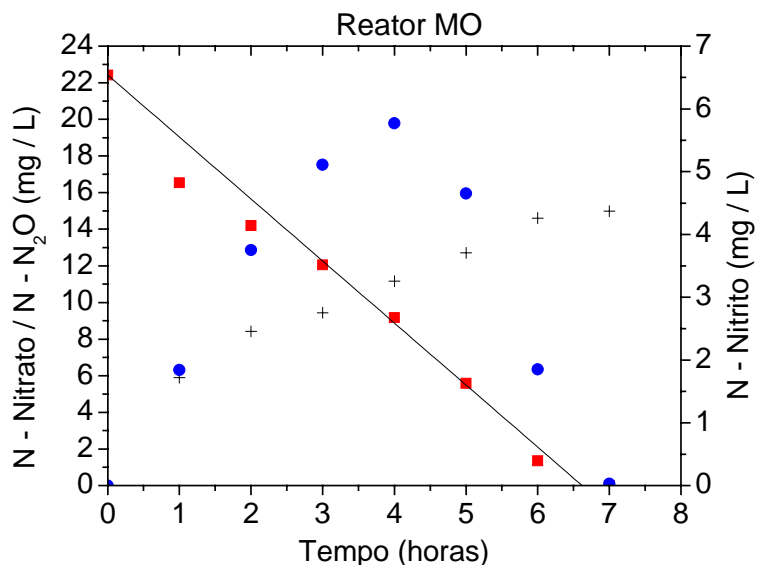

(b)

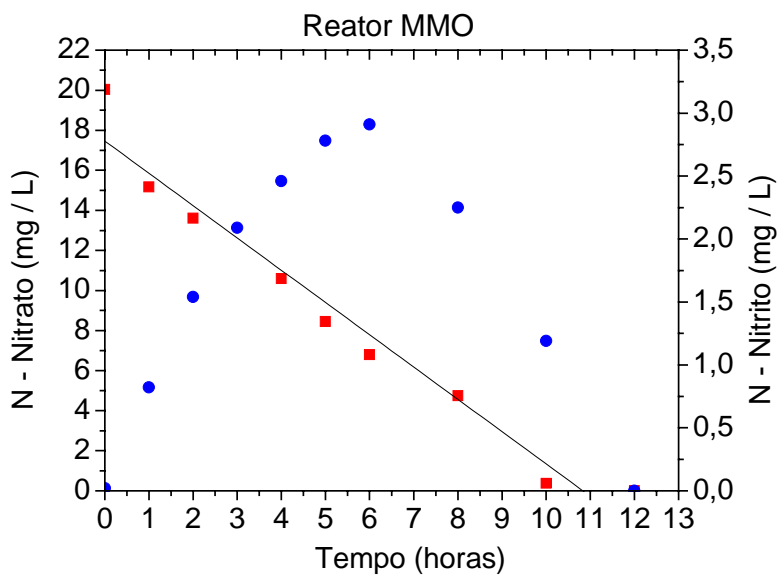

(d)

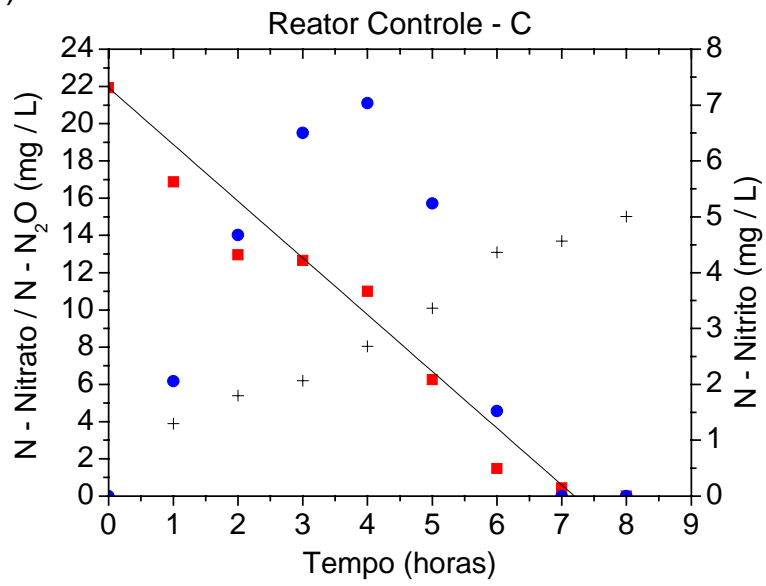

(e)

- Dados experimentais de nitrato .... Modelo cinético (eq. 7.10)
- Dados experimentais de nitrito Modelo cinético (eq. 7.11)
Dados experimentais de $\mathrm{N}_{2} \mathrm{C}$ Modelo cinético (eq. 7.12)

Figura 34 Ajuste de modelo cinético aos perfis temporais de concentração de nitrato, nitrito e $\mathrm{N}_{2} \mathrm{O}$ nos reatores: (a) M; (b) MO; (c) MM; (d) MMO e (e) C 
A produção de $\mathrm{N}_{2} \mathrm{O}$ não foi observada nos reatores que receberam suplementação com solução de metais (MM e MMO). Nesse caso, as rotas metabólicas de redução dissimilativa (RDNA) ou assimilativa de nitrato a amônia (RANA), ou ambas, podem ter ocorrido em substituição à desnitrificação.

O processo de redução de nitrato à amônia para assimilação celular é comum ocorrer quando existe, no meio líquido, carência de nitrogênio na forma amoniacal (MADIGAN et al., 1997). Aproximadamente $4 \mathrm{mg} / \mathrm{L}$ de $\mathrm{N}_{-} \mathrm{NH}_{4}{ }^{+}$encontravam-se disponíveis para assimilação celular no afluente dos reatores. Diante disso, é mais provável que a rota metabólica de RDNA tenha sido utilizada pelos microrganismos nos reatores MM e MMO.

Para o reator alimentado apenas com metano (reator $\mathrm{M}$ ), o modelo de reações múltiplas irreversíveis em série, tendo nitrito como único produto intermediário formado durante a desnitrificação, foi o que melhor representou os dados experimentais.

O consumo de nitrato seguiu reação de primeira ordem e o de nitrito ocorreu segundo reação de ordem zero, conforme apresentado na seq. 5.

$$
\mathrm{N}-\mathrm{NO}_{3}{ }^{-} \stackrel{\mathrm{k}_{1}}{\longrightarrow} \mathrm{N}-\mathrm{NO}_{2}^{-} \stackrel{\mathrm{k}_{2}}{\longrightarrow} \mathrm{N}-\mathrm{N}_{2}
$$

Dessa forma, a partir de balanço de massa em reator em batelada, foram obtidas as equações dos perfis de concentração de nitrato e nitrito em função do tempo (eq. 14 e 15):

$$
\begin{aligned}
& C_{\mathrm{NO}_{3}^{-}}=C_{\mathrm{NO}_{3}{ }^{-} \mathrm{o}} \cdot e^{-k_{1} t} \\
& C_{\mathrm{NO}_{2}^{-}}=C_{\mathrm{NO}_{2}{ }^{-} \mathrm{o}} \cdot\left(1-e^{-k 1 t}\right)-k_{2} t
\end{aligned}
$$

Não foi possível obter ajuste razoável do mesmo modelo cinético aos resultados dos outros reatores, principalmente para os dados de nitrito, apesar de, aparentemente, o comportamento ter sido muito semelhante para esses dados experimentais em todos os reatores.

Para os reatores MO e C (nos quais ocorreu a desnitrificação) e MM e MMO (em que a redução de nitrato não produziu $\mathrm{N}_{2} \mathrm{O}$ ), o consumo de nitrato seguiu reação de ordem zero, estando, portanto, representado por um modelo mais simples, conforme explicitado na equação (16). Para efeito comparativo, o mesmo modelo de reação de ordem zero para remoção de nitrato foi, também, ajustado aos dados do reator $\mathrm{M}$.

$$
C_{\mathrm{NO}_{3}{ }^{-}}=C_{\mathrm{NO}_{3}{ }^{-} \mathrm{o}}-k_{\mathrm{o}} t
$$


Nas equações (14), (15) e (16), $C_{\mathrm{NO}_{3}^{-}}$refere-se à concentração de nitrato, (mg N$\left.\mathrm{NO}_{3}{ }^{-} / \mathrm{L}\right) ; C_{\mathrm{NO}_{2}^{-}}$, à concentração de nitrito $\left(\mathrm{mg} \mathrm{N}-\mathrm{NO}_{2}{ }^{-} / \mathrm{L}\right) ; \mathrm{k}_{1}$, à constante de reação de primeira ordem de conversão de nitrato a nitrito; $k_{2}$, à constante de reação de ordem zero para conversão de nitrito a $\mathrm{N}_{2}$ e $\mathrm{k}_{0}$, à constante de reação de ordem zero para conversão de nitrato a $\mathrm{N}_{2}$. O índice (o) subscrito indica a concentração inicial.

É importante observar que os reatores desnitrificantes (MO e C) e os produtores de amônia (reatores MM e MMO) apresentaram o mesmo comportamento cinético quanto à relação entre a velocidade de consumo de nitrato e sua concentração. Nesses casos, a velocidade de conversão foi independente da concentração de nitrato no meio líquido.

Na Tabela 34, estão apresentados os valores dos parâmetros cinéticos aparentes obtidos para consumo de nitrato, segundo reação de ordem zero, em todos os reatores. Comparando-se os resultados obtidos nos reatores M e MO, constata-se que a presença de oxigênio (reator MO) tornou o processo de desnitrificação, na presença de metano, 30\% mais eficiente do que no reator $M$, que não recebeu oxigênio.

Tabela 34. Parâmetros cinéticos aparentes para modelo cinético de ordem zero para consumo de nitrato.

\begin{tabular}{cccccc}
\hline Parâmetros & \multicolumn{5}{c}{ Reator (Processo) } \\
\cline { 2 - 6 } cinéticos & $\mathrm{M}$ & $\mathrm{MO}$ & $\mathrm{C}$ & $\mathrm{MM}$ & MMO \\
aparentes & (desnitrificação) & (desnitrificação) & (desnitrificação) & (RDNA) & (RDNA) \\
\hline $\mathrm{k}_{\mathrm{o}}$ (mg/L.h) & $2,36 \pm 0,12$ & $3,39 \pm 0,10$ & $3,05 \pm 0,12$ & $1,58 \pm 0,15$ & $1,61 \pm 0,12$ \\
$\mathrm{R}^{2}$ & 0,945 & 0,974 & 0,948 & 0,936 & 0,961 \\
\hline
\end{tabular}

Como o reator C não recebeu nenhuma fonte exógena de carbono, a desnitrificação ocorreu através da utilização de fontes endógenas de carbono provenientes da decomposição do lodo. A utilização de lodo anaeróbio como doador de elétrons para a desnitrificação foi anteriormente reportada por outros autores (SOUSA e FORESTI, 1999).

Nos experimentos realizados com o reator anóxico comparativo, na fase $\mathrm{B}$, alimentado com metano e oxigênio (item 6.1), em que os efeitos da resistência à transferência de massa não foram minimizados, foi observado que a velocidade de consumo de nitrato também ocorreu segundo reação de ordem zero e foi igual a 2,37 mg/L.h (resultado também apresentado por SANTOS et al., 2002a). Tal valor foi, aproximadamente, 30\% inferior ao encontrado neste ensaio para o reator MO (3,39 mg/L.h), submetido à agitação contínua de 150rpm em "shaker”. A diferença entre esses valores indica que, quando metano é utilizado como doador de elétrons, os efeitos de transferência de massa exercem influência considerável sobre a cinética da desnitrificação. 
As velocidades de desnitrificação (Tabela 34) obtidas para os reatores MO e C foram, aproximadamente, duas vezes maiores que a velocidade de produção de Namoniacal (reatores MM e MMO).

Os valores dos parâmetros cinéticos obtidos para os reatores MM e MMO permitem admitir que o oxigênio não exerceu influência significativa sobre a cinética da remoção de nitrato. Por outro lado, a suplementação de micronutrientes favoreceu claramente o processo de redução de nitrato, predominante nesses reatores, frente a desnitrificação, conforme pôde ser observado pelos resultados dos reatores MM e MMO.

Na Tabela 35, são apresentados os parâmetros cinéticos aparentes obtidos para o modelo cinético de reações em série, ajustado aos dados obtidos quando apenas o metano foi utilizado como doador de elétrons. Na Figura 35, apresentam-se as velocidades de consumo de nitrato e de nitrito, sendo que o modelo cinético utilizado representou bem os dados experimentais.

Tabela 35. Parâmetros cinéticos para o modelo de reações múltiplas em série obtidos a partir dos dados utilizando metano como doador de elétrons (reator M)

\begin{tabular}{cc}
\hline Parâmetros cinéticos aparentes & Reator $\mathrm{M}$ \\
\hline $\mathrm{k}_{1}\left(\mathrm{~h}^{-1}\right)$ & $0,25 \pm 0,022$ \\
$\mathrm{k}_{2} \times 10^{4}\left(\mathrm{~mol}^{-1} \mathrm{l}^{-1} \cdot \mathrm{h}^{-1}\right)$ & $1,37 \pm 0,028$ \\
$\mathrm{R}^{2}$ para reação de $1^{\mathrm{a}}$ ordem & 0,936 \\
$\mathrm{R}^{2}$ para reação de ordem zero & 0,974 \\
\hline
\end{tabular}

O modelo cinético utilizado para representar os dados experimentais indicou (Figura 35) que a velocidade de consumo nitrito manteve-se inferior à de consumo de nitrato, aproximadamente $38 \%$ menor; ou seja, o consumo de nitrito foi a etapa limitante do processo reacional.

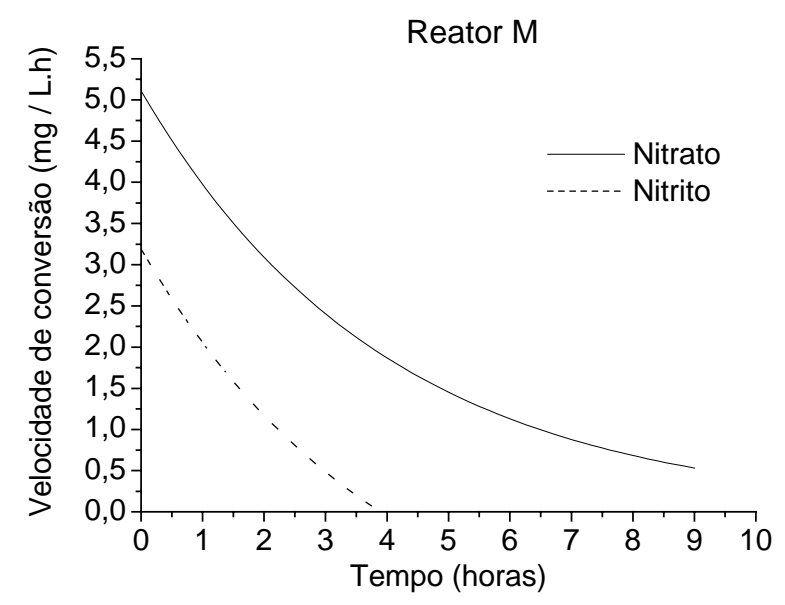

Figura 35. Velocidades de conversão de nitrato e de nitrito - Reator M 
Aparentemente, a população consumidora de nitrito encontrava-se mais bem estabelecida no reator MM, tendo em vista a concentração máxima observada de 1,3 mg $\mathrm{N}-\mathrm{NO}_{2}{ }^{-} / \mathrm{L}$, em relação ao reator $\mathrm{C}$, que foi de 7,0 $\mathrm{mg} \mathrm{N}-\mathrm{NO}_{2}{ }^{-} / \mathrm{L}$.

Os sólidos totais voláteis foram analisados no final da realização dos perfis temporais de concentração de nitrato, nitrito e $\mathrm{N}_{2} \mathrm{O}$, tendo sido obtidos os seguintes valores 18,48 g STV/L; 16,33 g STV/L; 15,19 g STV/L; 18,57 g STV/L e 20,80 g STV/L, para os reatores $\mathrm{M}, \mathrm{MO}, \mathrm{MM}, \mathrm{MMO}$ e C, respectivamente.

O monitoramento microscópico das morfologias presentes no lodo permitiu observar o predomínio de arqueas metanogênicas no início da operação de todos os reatores. Ao longo do tempo, foi observada a formação de lodo floculento, que constituiu fina camada sobre os grânulos. Além disso, a estrutura dos grânulos do lodo de inóculo tornou-se menos resistente, chegando, em alguns casos, a perder sua configuração, ou a ser utilizado como suporte (Figura 36b), em outros. Após dois meses de operação, os bacilos tornaram-se a morfologia predominante. Os bacilos observados nos reatores encontravamse inseridos em matrizes de polímero, na maioria das vezes formando aglomerados (Figura 36a).

No lodo floculento dos reatores M e MO, foi observada a presença de bacilos em cadeia (Figuras 37b, 38a e 38b), que não foram encontrados nos demais reatores.

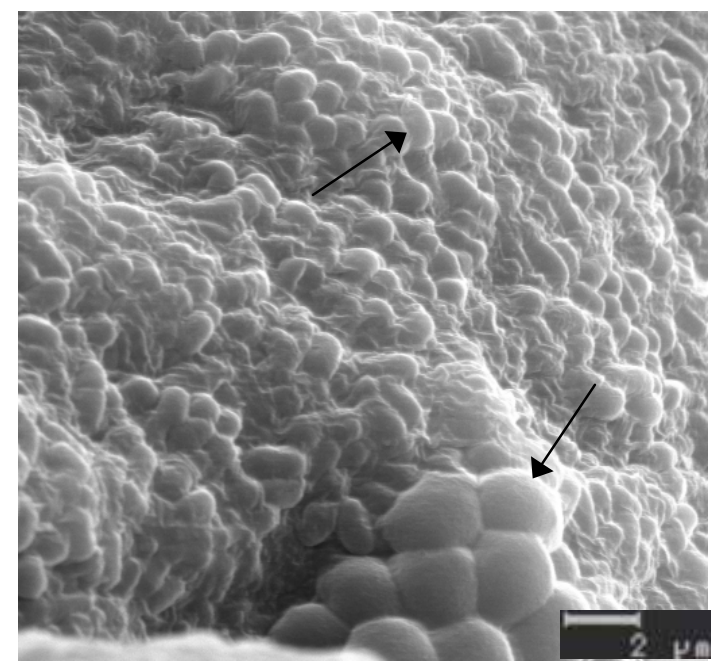

(a)

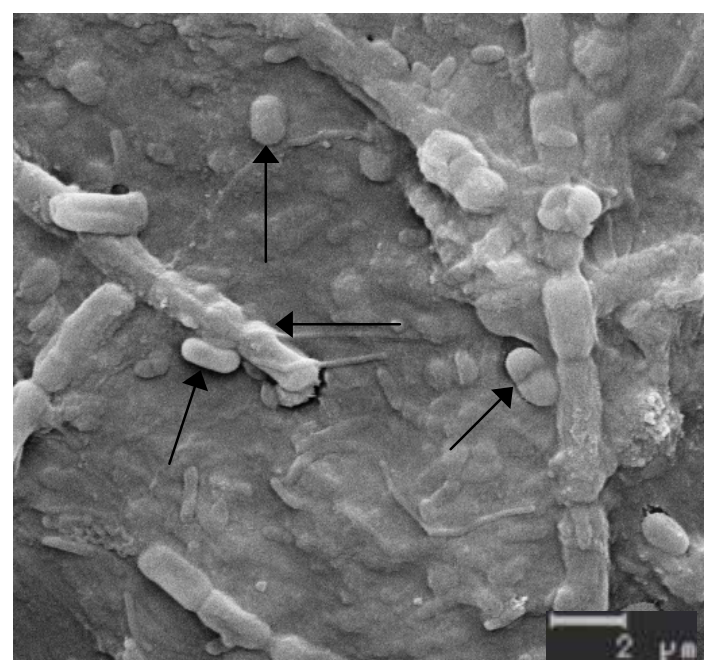

(b)

Figura 36. Morfologias observadas por meio de microscopia eletrônica de varredura (MEV): (a) bacilos em matriz polímero, encontrados no reator MM e (b) Bacilos e bacilos em cadeia na superfície do grânulo do reator MO. 


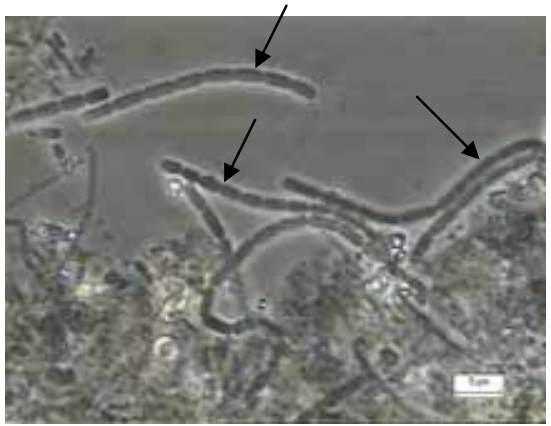

(a)

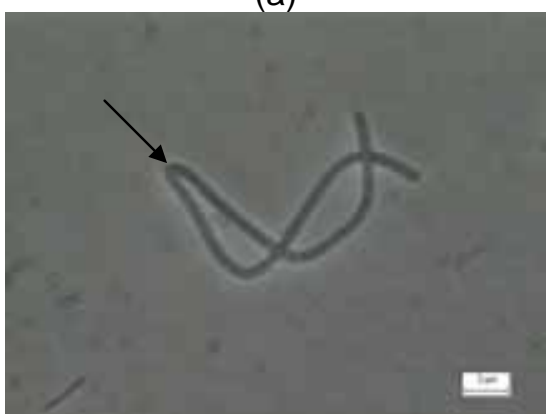

(d)

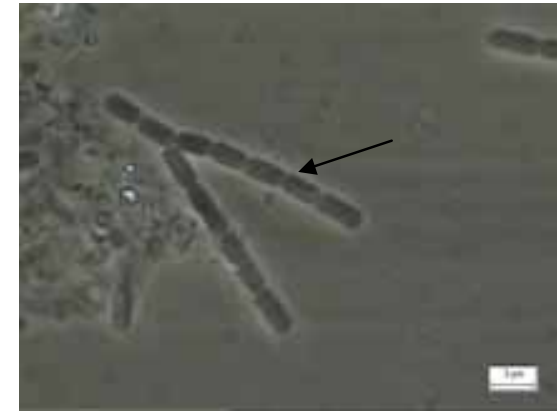

(b)

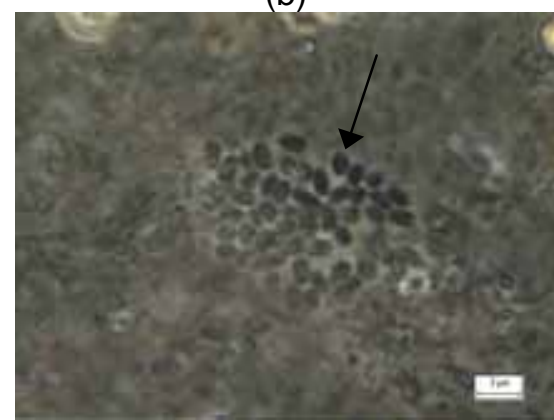

(e)

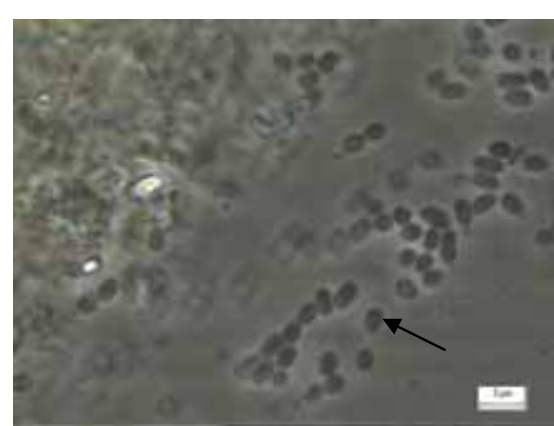

(c)

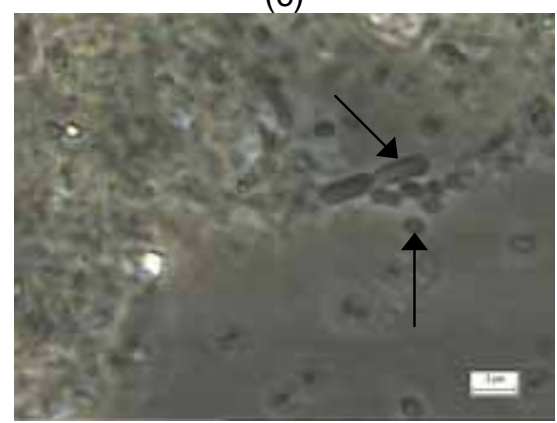

(f)

Figura 37. Morfologias observadas por meio de microscopia óptica comum: (a) Bacilos em cadeia, observados no lodo floculento do reator M; (b) Bacilos em cadeia observados no lodo floculento reator MO; (c) Bacilos ovalados observados no lodo floculento reator M; (d) Filamento observado em grânulo do reator MMO; (e) Aglomerado de bacilos ovalados observados em lodo floculento do reator $\mathrm{C}$ e (f) Bacilos e bacilos em cadeia em lodo floculento do reator $M$.

As amostras usadas na avaliação e comparação da diversidade microbiana, por meio da técnica do PCR/DGGE, dos reatores foram: In, do lodo utilizado como inóculo; $\mathrm{C}$, do reator controle; $\mathrm{M}$, do reator com metano; $\mathrm{MO}$, do reator com metano e oxigênio; MM, do reator com metano e metais e MMO, do reator com metano, metais e oxigênio; CP, controle positivo; e CN, controle negativo. Nas Figuras 39 e 40 são apresentados os padrões das bandas no gel de DGGE dos fragmentos de DNAr 16S amplificados com primers para os Domínios Bacteria e Archaea, respectivamente.

O processo de extração de DNA foi, também, realizado para as amostras representativas do lodo floculento, formado em todos os reatores. No entanto, não se obteve sucesso durante a realização dessa etapa para as amostras representativas dos reatores C, M, MO e MM, sendo possível a obtenção de DNA apenas para a amostra do reator MMO. Diante disso, tal amostra não foi utilizada por não permitir realizar comparação com os demais reatores. Os resultados obtidos e discutidos nesta seção são 
referentes as amostras de DNA, representativas do lodo granular, extraídas de todos os reatores.

A concentração de DNA do inóculo, observada nas bandas fracas (Figuras 39 e 40), encontra-se, aparentemente, inferior à dos reatores. Isso pode ser conseqüência do longo período (6 meses) de armazenamento em geladeira $\left(\sim 4^{\circ} \mathrm{C}\right)$, antes de sua utilização nos reatores. Esse período excessivo de armazenamento deve ter provocado degradação do material genético dos microrganismos.

É importante constatar que, aparentemente, as populações microbianas presentes nos reatores MM e MMO encontravam-se, também, presentes, em sua maioria, nos reatores $\mathrm{M}$ e MO. Isto pode indicar a presença de microrganismos que fazem a RDNA ou a RANA, também nos reatores $\mathrm{M}$ e MO. No entanto, as bandas mais fortes $(\mathbf{1}, \mathbf{2}, 3$ e 4Figura 38b), representativas das populações com maior expressão em M e MO, não foram observadas em MM e MMO, podendo indicar a ocorrência simultânea de populações desnitrificantes e redutoras de nitrato à amônia em M e MO.

Não é possível garantir que os reatores M e MM encontravam-se sob condições de anaerobiose estrita. Diante disso, é provável que bactérias metanotróficas tenham participado dos processos bioquímicos que ocorreu nos reatores $\mathrm{M}, \mathrm{MO}, \mathrm{MM}$ e MMO, devido à diferença entre a população de bactérias observada nesses reatores, quando comparadas com a do reator $\mathrm{C}$. Tal diferença deve estar relacionada à seleção de bactérias pela fonte de carbono utilizada.

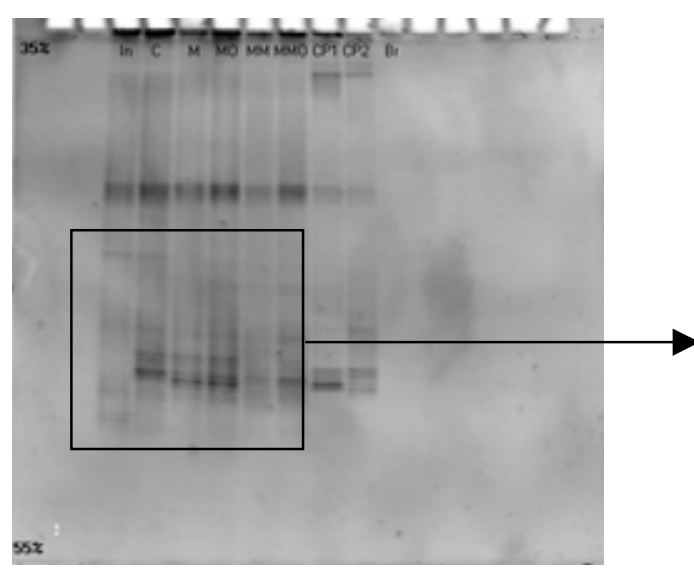

(a)

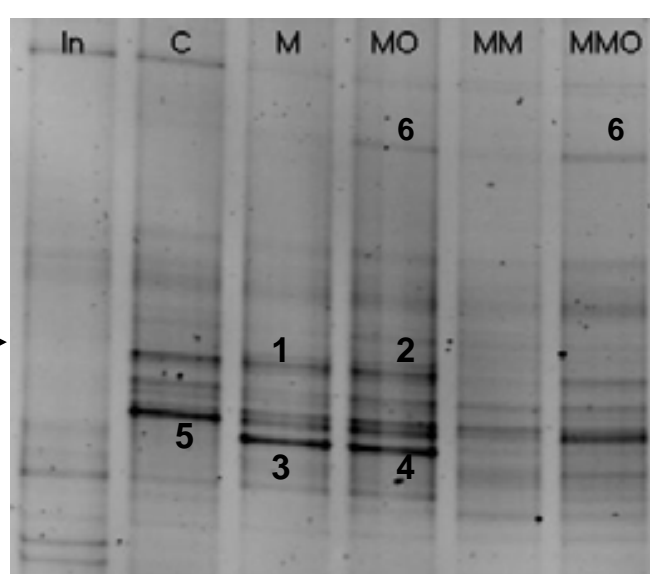

(b)

Figura 38. Diversidade de microrganismos pertencentes ao Domínio Bacteria nas amostras do inóculo (In) e dos reatores C, M, MO, MM e MMO: (a) gel de DGGE e (b) ampliação de região específica do gel. 
Os parâmetros cinéticos (Tabela 35) de ordem zero para desnitrificação, na presença de metano e oxigênio (MO), foram muito próximos aos obtidos quando nenhuma fonte de carbono foi adicionada ao sistema (reator $\mathrm{C}$ ). Contudo, a diversidade microbiana presente em M e MO foi diferente de C, principalmente em relação às bandas 3 e 4 (Figura 38b) que não foram observadas no reator C. Essas bandas não foram observadas em nenhum outro reator, podendo ser representativas dos bacilos em cadeia (Figura 38b), por estes terem sido visualizados, por microscopia de contraste de fase, apenas em M e MO. É provável, portanto, que as bandas 3 e $\mathbf{4}$ da Figura 38b estejam relacionadas à presença de microrganismos desnitrificantes que utilizavam metano como única fonte de elétrons.

A banda 5 (Fig. 39b), indicativa da presença de microrganismo com grande expressão no reator $\mathrm{C}$, e pequena significância no inóculo, deve estar relacionada ao desenvolvimento de população desnitrificante utilizadora de fontes internas de carbono e energia.

Em relação à diversidade de microrganismos pertencentes ao Domínio Archaea (Figura 39), é possível observar que houve desenvolvimento dessa população ao longo da operação de todos os reatores. É importante destacar que, tanto nos reatores desnitrificantes (C, M e MO), quanto nos que ocorreu a redução de nitrato à amônia (MM e MMO), não foi detectada produção de gás metano durante a realização dos perfis de concentração de nitrato e de nitrito.

Como o produto gasoso de interesse neste trabalho foi $\mathrm{o} \mathrm{N}_{2} \mathrm{O}$, a composição do head-space não foi avaliada após o nitrato e o nitrito terem sido completamente reduzidos (o que ocorreu após, aproximadamente, 9 horas). É provável que outras reações bioquímicas tenham ocorrido durante as 15 horas remanescentes do ciclo de batelada. Após o completo desaparecimento de nitrato do meio líquido, o potencial redox torna-se mais favorável ao desenvolvimento de arqueas. Estes microrganismos podem, nos reatores M, MO, MM e MMO, ter utilizado compostos intermediários (como metanol ou ácido acético) produzidos por bactérias metanotróficas, como fontes de carbono e energia. No entanto, no reator controle, outras fontes como hidrogênio e o dióxido de carbono devem ter sido utilizadas. De fato, foram observados bacilos fluorescentes e arqueas semelhantes a Methanosarcina e Methanosaeta, em todos os reatores no final da operação. 


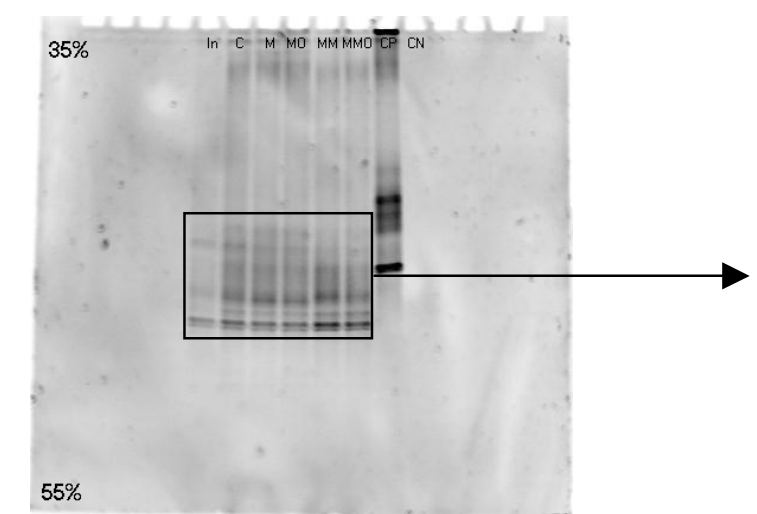

(a)

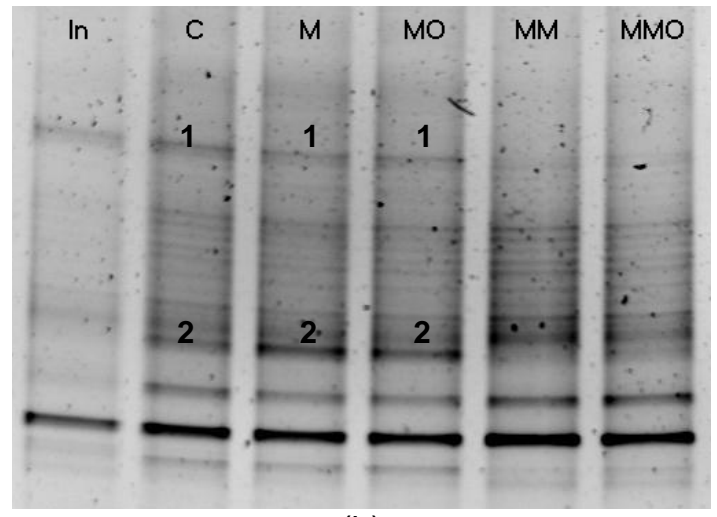

(b)

Figura 39. Diversidade de microrganismos pertencentes ao Domínio Archaea em amostras do inóculo (In) e reatores C, M, MO, MM e MMO: (a) gel de DGGE e (b) ampliação da região específica do gel.

A presença de oxigênio não teve, aparentemente, influência significativa sobre a seleção das populações de arqueas presentes nos reatores MO e MMO, quando comparados com os reatores $\mathrm{M}$ e MM, respectivamente. Pequena diferença é observada em relação à população de bactérias nos reatores MO e MMO, em que a banda 6 (Figura 38b) foi mais expressiva apenas nos reatores que receberam oxigênio. Tal observação permite concluir que, tanto os microrganismos desnitrificantes, quanto os que realizaram o processo de redução de nitrato à amônia, foram tolerantes à presença do oxigênio.

A influência da presença de metais sobre a rota metabólica de redução de nitrato, utilizada pela população de microrganismos presentes nos reatores MM e MMO, foi verificada pela técnica de Biologia Molecular empregando fragmentos de DNAr 16S. Observou-se diferença entre a diversidade bacteriana nesses reatores, em comparação com os demais, indicando que grupos de bactérias distintos participaram do processo de redução de nitrato à amônia. No entanto, em relação ao Domínio Archaea, tal influência foi menos significativa, sendo que os reatores que não receberam adição de metais (C, $\mathrm{M} \mathrm{e}$ MO) apresentaram maior diversidade de arqueas do que os reatores que foram suplementados com metais (MM e MMO). Destaca-se a seleção das populações microbianas, representadas pelas bandas 1 e 2 (Figura 39b), dos reatores MM e MMO. 


\subsection{Ensaio de Purificação}

Neste ensaio, os inóculos utilizados foram as amostras de lodo proveniente dos reatores M, MO, MM, MMO e C. Cada amostra foi incubada na presença de nitrato e de nitrito. Não foram observadas diferenças entre as populações consumidoras de nitrato e de nitrito em nenhuma das amostras.

Nas Tabelas 36 e 37 são apresentadas as morfologias observadas nos frascos com turvação, das maiores diluições. $\mathrm{O}$ índice (3), indica que a amostra foi incubada na presença de nitrato e (2), na presença de nitrito.

Tabela 36. Morfologias observadas durante purificação das amostras provenientes dos reatores anóxicos alimentados com metano.

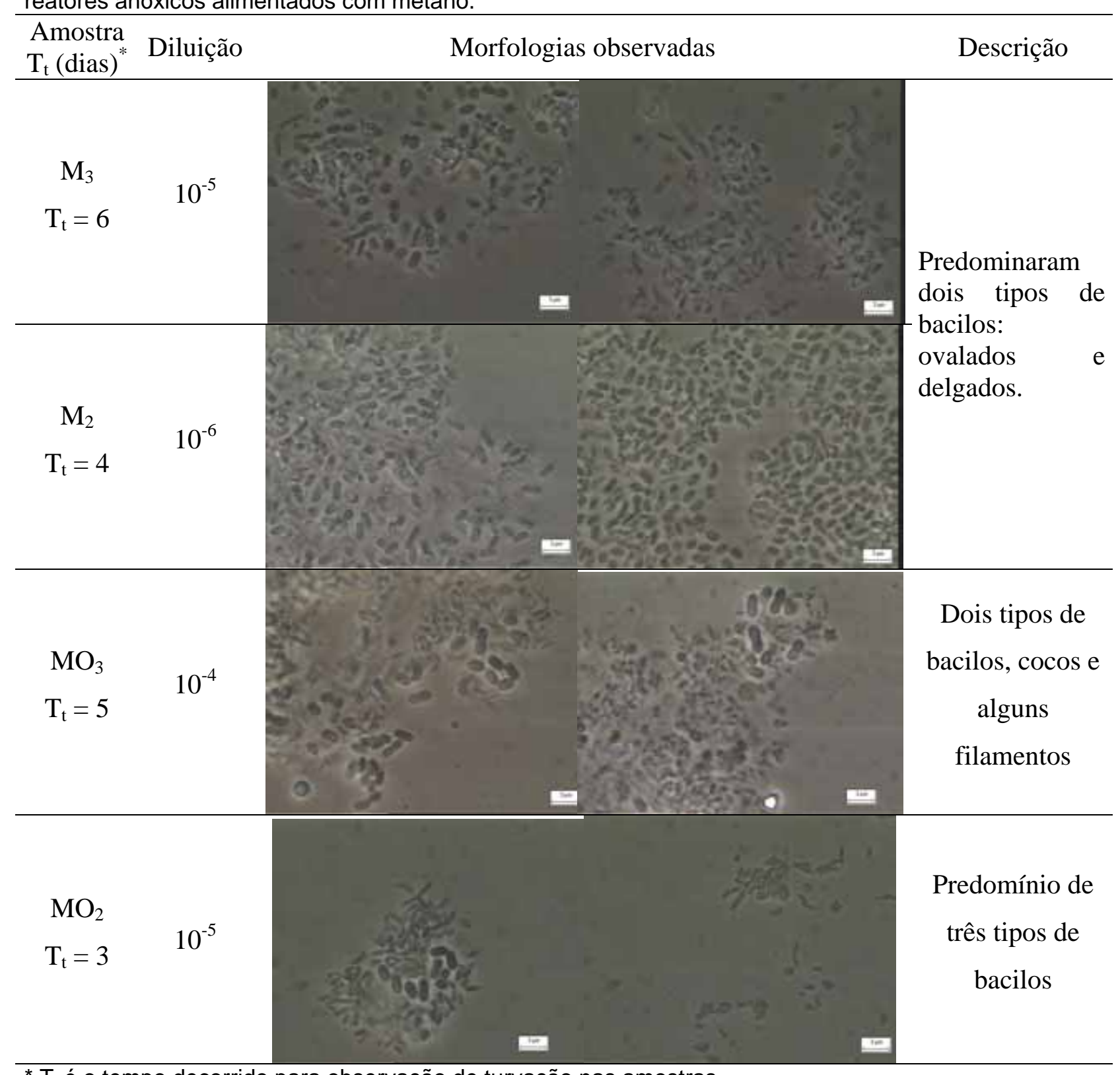

${ }^{*} T_{t}$ é o tempo decorrido para observação de turvação nas amostras. 
Tabela 37. Morfologias observadas durante purificação das amostras provenientes dos reatores anóxicos alimentados com metano.

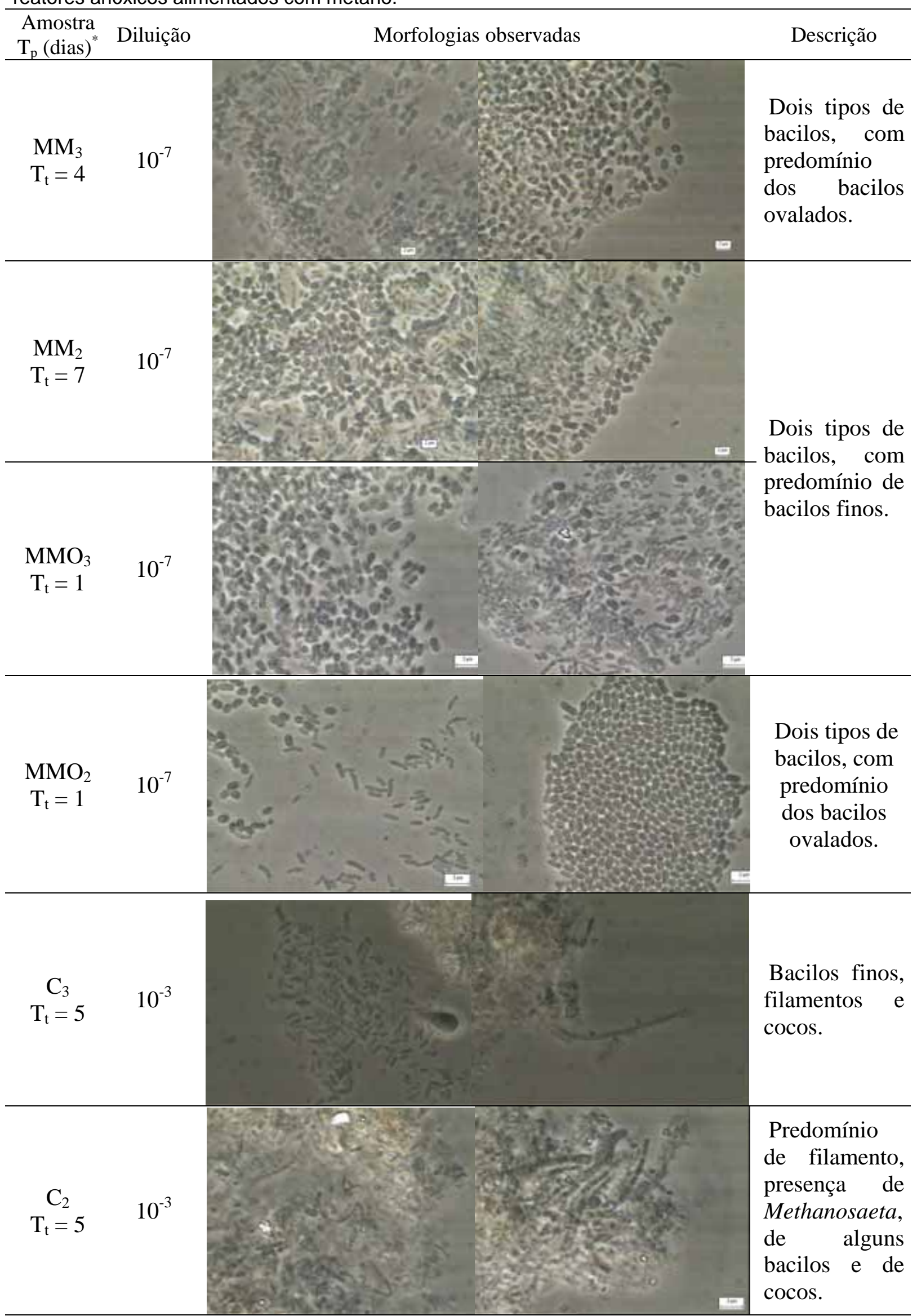

* $T_{t}$ é o tempo decorrido para observação de turvação nas amostras. 
As observações morfológicas permitiram constatar que dois tipos principais de bacilos predominaram entre as amostras, tanto na presença de nitrato, como de nitrito. Os bacilos em cadeia, observados nos reatores M e MO (Figura 37a e 37b), não cresceram durante a purificação.

Nas amostras purificadas do controle $\left(\mathrm{C}_{3}\right.$ e $\left.\mathrm{C}_{2}\right)$ ainda haviam muitos dos microrganismos presentes nos reatores, inclusive arqueas metanogênicas. As amostras encontravam-se, também, muito sujas, provavelmente devido à presença de polímeros extracelulares excretados por microrganismos ativos e inativos, uma vez que a maior diluição que apresentou turvação $\left(10^{-3}\right)$ ainda possuía biomassa originária do inóculo.

Nas amostras $\mathrm{MMO}_{3}$ e $\mathrm{MMO}_{2}$, foi observado o crescimento de microrganismos após 24h. As morfologias observadas nesses reatores referem-se, provavelmente, a microrganismos aeróbios, devido à presença de oxigênio no meio.

A partir dessas observações microscópicas, as amostras foram submetidas à etapa de aumento da massa celular. O intervalo de tempo de sete dias (ou uma semana) foi mantido entre as adições de nutrientes visando o aumento de massa celular, com o intuito de promover repouso dos microrganismos. Nesse intervalo, as amostras eram mantidas em geladeira.

Após o primeiro aumento de massa celular (de $30 \mathrm{~mL}$ para $60 \mathrm{~mL}$ ), as células foram submetidas a exame para observação das características morfológicas, através do método diferencial de coloração Gram.

Na Figura 40 encontram-se apresentadas as morfologias observadas durante o aumento da massa celular das culturas em purificação, juntamente com os resultados obtidos da coloração Gram.

Foi observado, durante o aumento da massa celular, que houve mais um processo de purificação dos microrganismos. Nas amostras $\mathrm{M}_{3}, \mathrm{M}_{2}$ e $\mathrm{MO}_{3}$, os bacilos ovalados desapareceram. As amostras $C_{3}$ e $C_{2}$ encontravam-se mais limpas e foram selecionados bacilos finos. Foi evidente o predomínio dos dois tipos de bacilos nas amostras $\mathrm{MMO}_{3}$ e $\mathrm{MMO}_{2}$; além dessas células crescerem após 24 horas, a concentração celular foi, aparentemente, bem maior nessas amostras, do que nas demais.

Todas as células coradas foram gram-negativas, o que quer dizer que essas bactérias contêm concentrações mais elevadas de lipídeos e suas paredes são também mais finas, quando comparadas com as gram-positivas. A maioria dos microrganismos desnitrificantes conhecidos, até o momento, são descritos ser gram-negativos. 


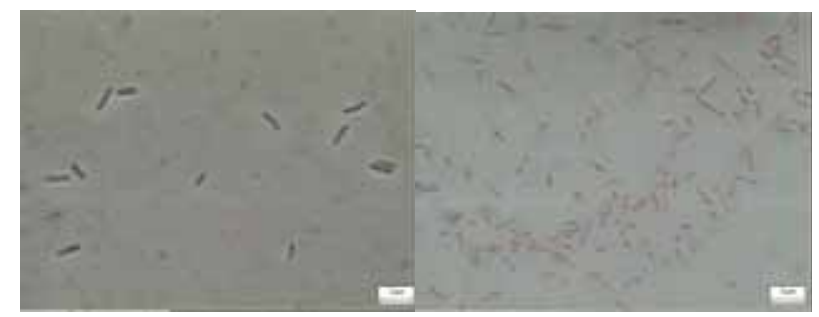

(a)

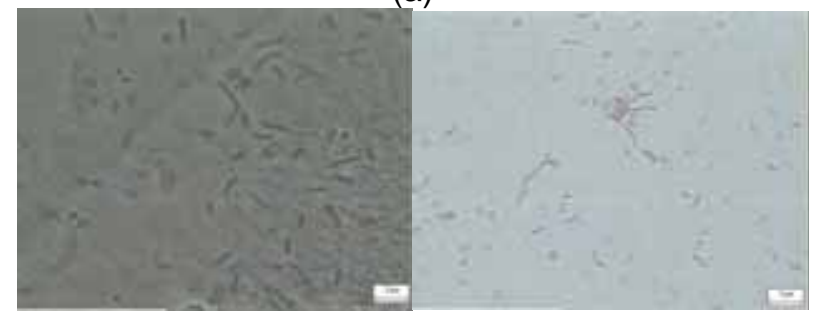

(c)

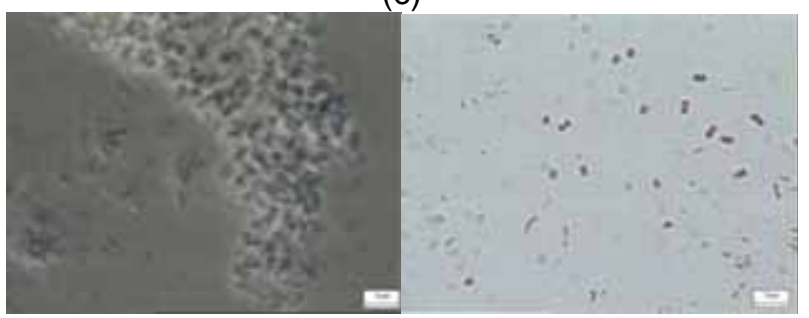

(e)

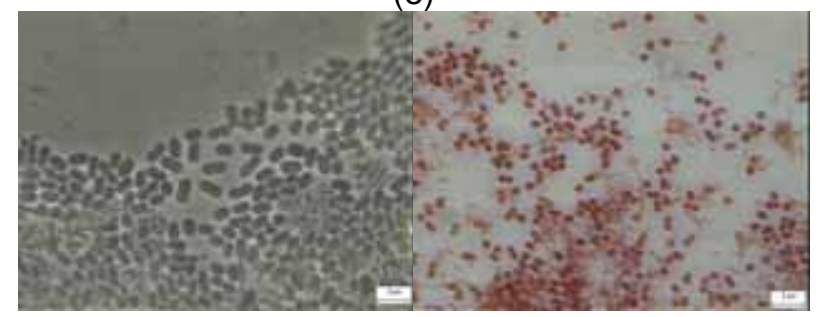

(g)

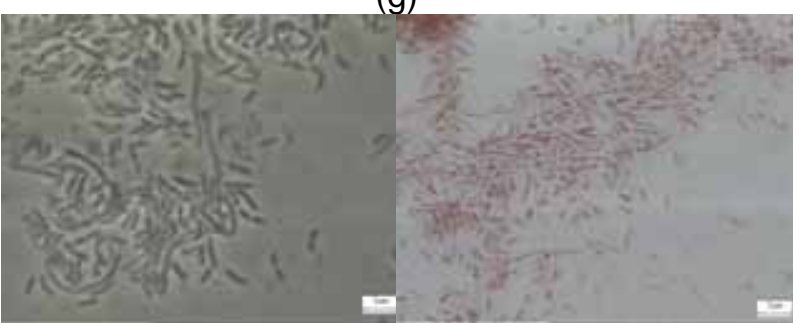

(i)

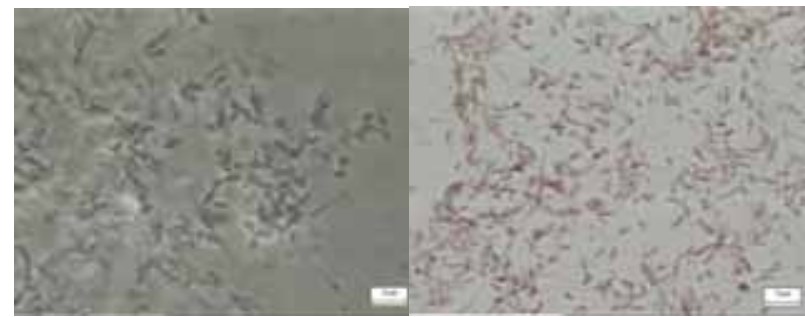

(b)

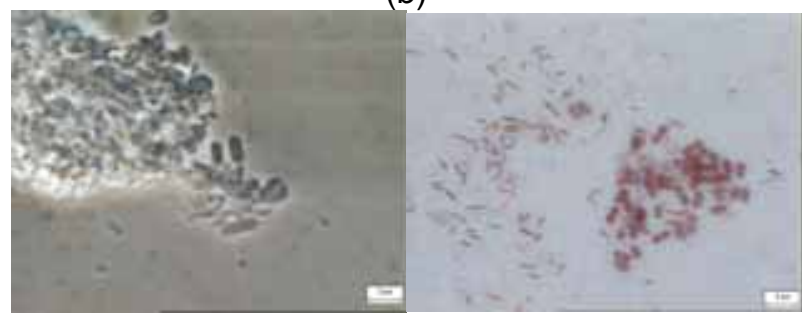

(d)

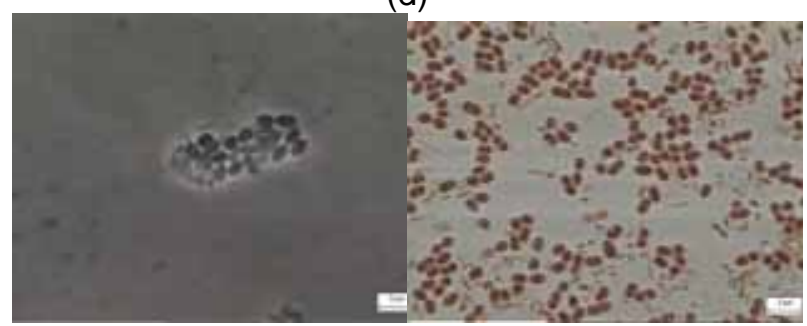

(f)

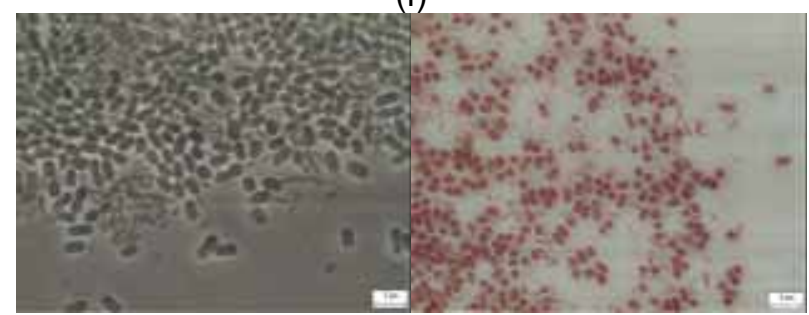

(h)

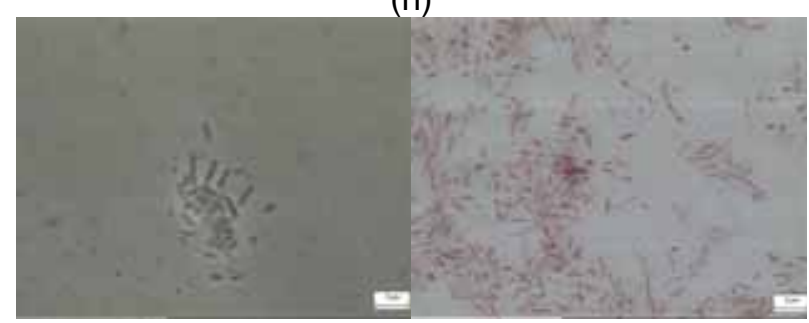

(j)

Figura 40. Morfologias observadas em aumento da massa celular e coloração Gram, nas amostras: (a) $\mathrm{M}_{3} ;$ (b) $\mathrm{M}_{2}$; (c) $\mathrm{MO}_{3} ;$ (d) $\mathrm{MO}_{2}$; (e) $\mathrm{MM}_{3}$; (f) $\mathrm{MM}_{2} ;$ (g) $\mathrm{MMO}_{3}$; (h) $\mathrm{MMO}_{2}$ (i) $\mathrm{C}_{3} ;$ (j) $\mathrm{C}_{2}$.

Foi dado prosseguimento ao processo de aumento de massa celular, mantendo-se o intervalo de repouso de uma semana entre cada aumento. Os volumes de células obtidos, para cada reator, são apresentados na Tabela 38.

Tabela 38. Volume de células purificadas obtidas para cada condição nutricional

\begin{tabular}{ccccccccccc}
\hline Amostra & $\mathrm{M}_{3}$ & $\mathrm{M}_{2}$ & $\mathrm{MO}_{3}$ & $\mathrm{MO}_{2}$ & $\mathrm{MM}_{3}$ & $\mathrm{MM}_{2}$ & $\mathrm{MMO}_{3}$ & $\mathrm{MMO}_{2}$ & $\mathrm{C}_{3}$ & $\mathrm{C}_{2}$ \\
\hline $\begin{array}{c}\text { Volume } \\
(\mathrm{mL})\end{array}$ & 80 & 80 & 80 & 80 & 130 & 80 & 1000 & 1000 & 80 & 80 \\
\hline
\end{tabular}




\subsection{Crescimento das culturas em meio sólido}

Para observação das características das culturas puras obtidas para as amostras $\mathrm{MMO}_{3}$ e $\mathrm{MMO}_{2}$, foi realizado o crescimento das culturas em meio sólido, em placa de Petri. As características de ambas as colônias foram muito semelhantes tendo bordo circular, consistência gelatinosa e coloração branco leitosa. A principal diferença foi observada em relação ao tamanho médio em que, para $\mathrm{MMO}_{3}$ foi igual a 0,795 mm e para $\mathrm{MMO}_{2}$ igual a 1,030 mm. As observações microscópicas das colônias isoladas são apresentadas na Figura 41.

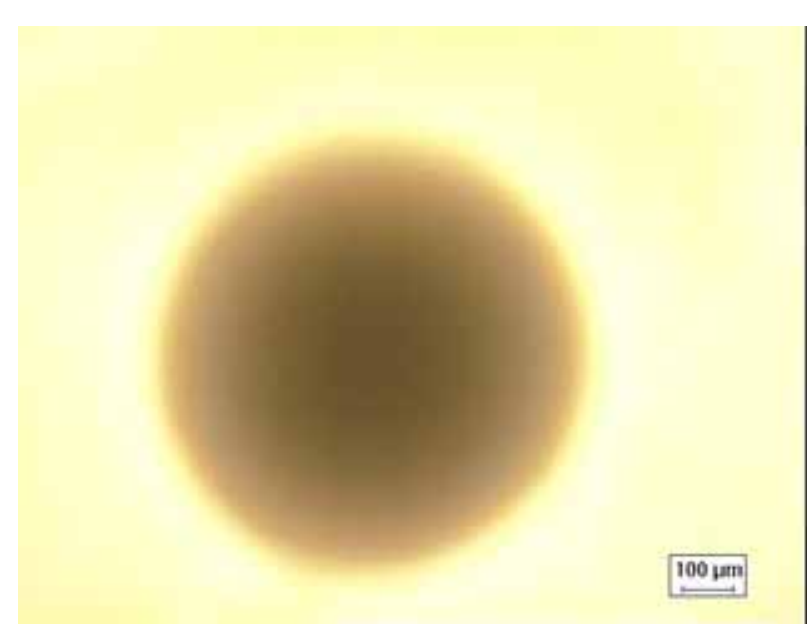

(a)

Figura 41. Colônias obtidas para as amostras: $(\mathrm{a}) \mathrm{MMO}_{3}$ e (b) $\mathrm{MMO}_{2}$

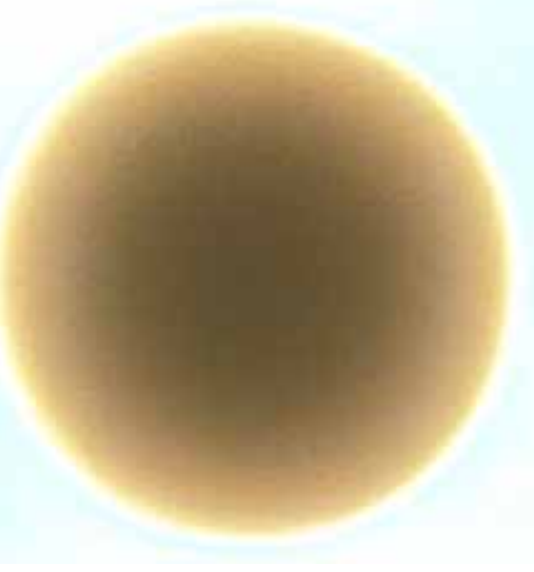

(b)

\subsection{Ensaio para obtenção da cinética de crescimento celular}

O ensaio para obtenção da cinética de crescimento celular foi realizado para a amostra $\mathrm{MMO}_{3}$, em duplicata. Os dois reatores, contendo culturas purificadas, foram submetidos a uma única batelada, na presença de metano, metais, oxigênio e nitrato.

Foram coletadas amostras para realização de nitrato, nitrito e ácidos voláteis. Nitrato e nitrito foram analisados simultaneamente, durante a realização do ensaio, e as demais amostras foram congeladas em freezer $\left(-20^{\circ} \mathrm{C}\right)$ para análise posterior.

Após 8 horas de ensaio, foi observada turvação dos reatores, indicando crescimento visual das células. As concentrações de nitrato e nitrito permaneceram constantes durante 48 horas de ensaio, em todos os reatores com as culturas puras.

Após 18 horas de ensaio foi realizada observação morfológica das culturas através de microscopia óptica. As células dos reatores $\mathrm{MMO}_{3}$, na presença de oxigênio, apresentavam-se em excelentes condições, inclusive em visível processo de divisão celular. 
Decorrido o período de realização do ensaio, o licor misto de ambos os reatores apresentava-se amarelado, provavelmente devido à precipitação de óxido de ferro, como conseqüência da reação química entre o ferro, presente na solução de metais, com o oxigênio. A agitação em "shaker" deve ter aumentado a quantidade de oxigênio dissolvido no meio líquido e proporcionado tal reação.

Após 48 h de ensaio, esperava-se que o oxigênio dissolvido fosse completamente consumido por bactérias metanotróficas, permitindo que o nitrato começasse a ser reduzido por microrganismos desnitrificantes. Tal processo não ocorreu e o ensaio foi finalizado. Nesta fase, as morfologias observadas nos reatores encontravam-se esporuladas. Como o nitrato não foi reduzido, foi possível constatar que as culturas selecionadas não eram constituídas por bactérias desnitrificantes.

A média dos valores obtidos, nos dois reatores, a partir da quantificação dos ácidos voláteis, por HPLC, são apresentados na Figura 42. É possível observar que o ácido fórmico $(\sim 3 \mathrm{mg} / \mathrm{L})$ foi produzido nos primeiros 30 minutos, sendo que sua concentração permaneceu praticamente estável durante o período de experimento. O ácido acético foi sendo formado ao longo do tempo de batelada e atingiu a concentração de, aproximadamente, $7 \mathrm{mg} / \mathrm{L}$, após 10 h de experimento.

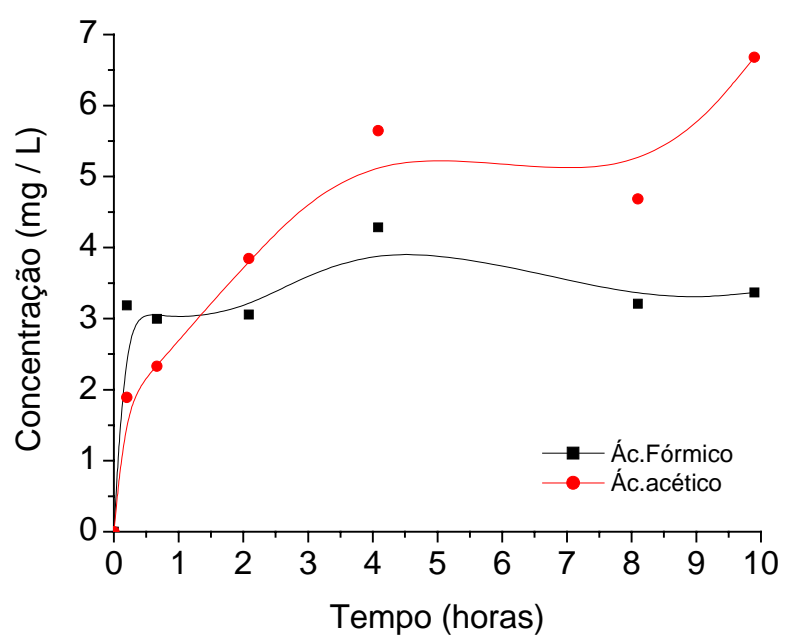

Figura 42. Ácidos voláteis quantificados no ensaio cinético - cultura purificada a partir do reator $\mathrm{MMO}$, na presença de nitrato

O principal composto conhecido por ser produzido por bactérias metanotróficas, o metanol, não foi quantificado neste ensaio. No entanto, Costa et al. (2000) obtiveram que o acetato foi o composto produzido por bactérias metanotróficas que cresceram sob condições limitantes de oxigênio. Por outro lado, o formiato é apresentado, por Madigan 
et al. (1997), como sendo produto da oxidação bioquímica do metano, realizada por bactérias metanotróficas, conforme descrito na seq. 2.

O fato de os compostos nitrato e nitrito não terem sido reduzidos do meio líquido, aliado à produção dos ácidos fórmico e acético e à disponibilidade de metano e oxigênio nos reatores, permite inferir que os microrganismos purificados sejam representativos de bactérias metanotróficas.

Amostras de DNA das culturas de MMO, purificadas na presença de nitrato e de nitrito, foram amplificadas por PCR, através da utilização de primer para o Domínio Bacteria, e utilizadas como controle positivo, durante a avaliação da diversidade microbiana presente nos reatores alimentados com metano (item 6.3), cujos resultados são apresentados na Figura 39. Os padrões de bandas obtidos a partir do DGGE, para as amostras do reator alimentado com metano, metais e oxigênio e para as culturas purificadas na presença de nitrato $\left(\mathrm{MMO}_{3}\right.$ - utilizado como controle positivo1 - CP1) e de nitrito $\left(\mathrm{MMO}_{2}\right.$ - utilizado como controle positivo2 - CP2), são apresentados na Figura 43.

É possível verificar (Figura 43) que a banda 1 foi observada, tanto nas culturas purificadas na presença de nitrato e de nitrito, como no reator MMO. Portanto, é possível que bactérias metanotróficas tenham participado dos processos bioquímicos que ocorreram no reator MMO. Além disso, a banda 2, representativa de população microbiana presente apenas nas culturas purificadas de $\mathrm{MMO}_{2}$, foi encontrada, também, no reator MMO.

É importante destacar que os bacilos, observados por microscopia óptica, nas culturas purificadas $\mathrm{MMO}_{3}$ e $\mathrm{MMO}_{2}$, apresentaram diversidade considerável de bandas no gel de DGGE (Figura 43 - CP1 e CP2). Acreditava-se, inicialmente, tratar-se de uma co-cultura de bacilos. No entanto, os resultados de DGGE permitiram observar a presença de mais de duas bandas nas amostras das culturas purificadas. Esse resultado indica que mais de duas populações microbianas, provavelmente de bactérias metanotróficas, foram purificadas a partir do reator MMO.

De forma semelhante, Svenning et al. (2003) observaram, para cultura de bactérias metanotróficas, purificada a partir de amostra de solo, a presença de bacilos curvos e retos com coloração amarronzada que resultou em 10 linhagens diferentes de bactérias metanotróficas, analisadas através da técnica de fingerprinting ERIC - PCR, usada para avaliar a diversidade genética a nível de linhagem. 


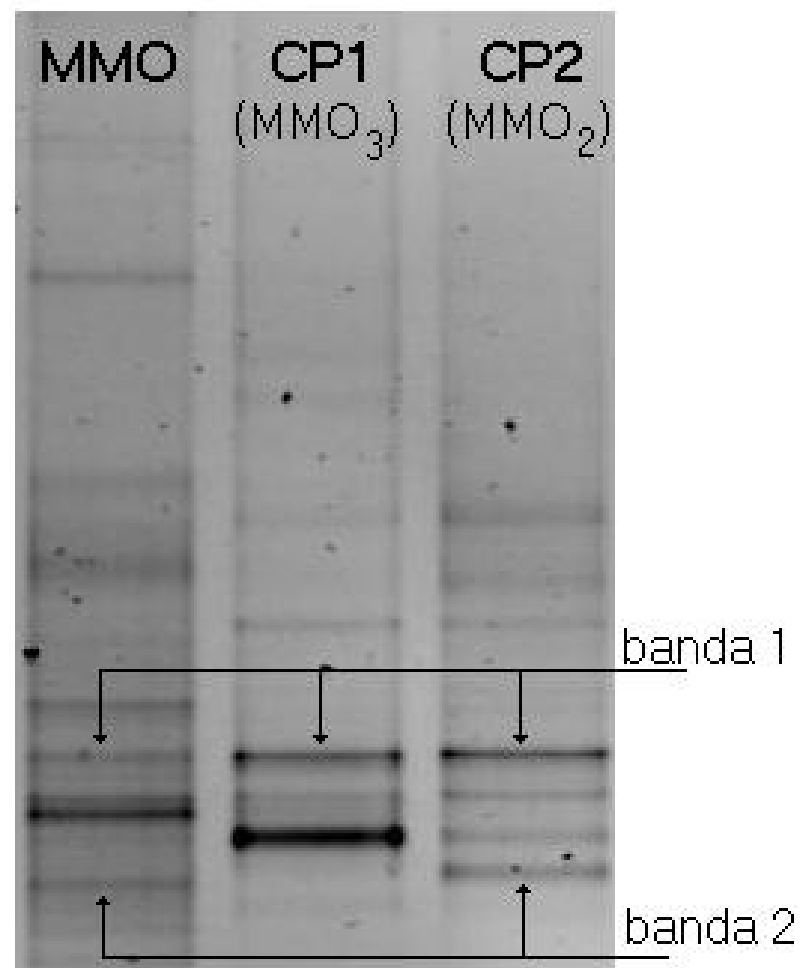

Figura 43. Separação das bandas em gel de DGGE das amostras do reator MMO e das culturas purificadas $\mathrm{MMO}_{3}(\mathrm{CP} 1)$ e $\mathrm{MMO}_{2}(\mathrm{CP} 2)$. 


\section{CONCLUSÕES}

Os resultados obtidos durante a operação dos reatores anóxicos, a análise comparativa entre os valores dos parâmetros cinéticos determinados e a análise da diversidade microbiana presente, nos reatores ensaiados, permitiram concluir que:

\subsection{Conclusões Gerais}

A desnitrificação completa ocorreu com todos os doadores de elétrons (etanol, metanol e metano) utilizados, porém com diferentes velocidades. Embora esses doadores de elétrons já tivessem sido testados por outros pesquisadores, os resultados obtidos permitiram elucidar alguns aspectos do processo de desnitrificação de efluentes de reatores aeróbios nitrificados.

Os valores das constantes cinéticas obtidas, bem como dos tempos necessários para se atingir a desnitrificação completa, permitiram concluir que o etanol foi o doador de elétrons mais eficiente para a desnitrificação. Esse resultado é particularmente importante, porque a desnitrificação com o uso de metanol tem sido a preferida por muitos pesquisadores.

Foram obtidos resultados distintos de eficiências de desnitrificação quando foram aplicadas relações $\mathrm{C} / \mathrm{N}$ idênticas dos doadores específicos de elétrons, etanol e metanol, uma vez que as capacidades específicas de doar elétrons, por unidade de concentração desses compostos são distintas. Conclui-se que a relação $\mathrm{C} / \mathrm{N}$ não se constitui parâmetro preciso para a aplicação do processo de desnitrificação, devendo ser substituído por outro que leve em conta a capacidade de doar elétrons dos compostos.

Apesar de o metano não ter sido tão eficiente como doador de elétrons quanto os demais, a desnitrificação foi alcançada com sucesso, tendo sido detectado que a resistência à transferência de massa exerce grande influência sobre o processo. Como para estar disponível à biomassa o metano deve estar dissolvido na massa líquida, é 
provável que o processo de transferência da fase gasosa para a fase líquida, nos reatores ensaiados, tenha sido lento, inclusive em função da baixa solubilidade do gás metano.

A estrutura granular não foi adequada para manutenção da biomassa desnitrificante, uma vez que a maior concentração de bactérias, observada através da técnica de PCR/DGGE, foi verificada ocorrer no lodo floculento que se desenvolveu em todos os reatores, ao longo do tempo de operação.

\subsection{Conclusões por Experimento}

\section{- Reatores Anóxicos Comparativos}

A elevada concentração de $\mathrm{N}$-amoniacal, que foi observada no início da operação dos reatores alimentados com etanol, metanol e metano decorreu, provavelmente, do processo de autólise do material celular inativo, presente no lodo anaeróbio metanogênico utilizado como inóculo.

A relação $\mathrm{C} / \mathrm{N}$ igual a 1,0, aplicada aos reatores que receberam etanol e metanol como doadores de elétrons, foi a mais adequada para promover o processo de desnitrificação, dentre os valores avaliados (1,0; 0,75 e 0,5). A partir da relação C/N igual a 0,75, a quantidade de etanol e de metanol tornaram-se insuficientes para proporcionar a redução completa do nitrato adicionado aos reatores.

Para todas as relações $\mathrm{C} / \mathrm{N}$ avaliadas (reatores com etanol e metanol), o consumo de nitrato seguiu o modelo cinético de reação de primeira ordem. As constantes cinéticas de primeira ordem obtidas, quando o etanol foi o doador de elétrons, foram iguais a 4,43 $\mathrm{h}^{-1}, 1,64 \mathrm{~h}^{-1}$ e $0,37 \mathrm{~h}^{-1}$, para as relações $\mathrm{C} / \mathrm{N}$ iguais a 1,$0 ; 0,75$ e 0,5 , respectivamente. Para o metanol, tais constantes foram iguais a $1,33 \mathrm{~h}^{-1} ; 0,58 \mathrm{~h}^{-1}$; e 0,31 $\mathrm{h}^{-1}$, para as relações $\mathrm{C} / \mathrm{N}$ iguais a 1,$0 ; 0,75$ e 0,5 , respectivamente. Tais resultados demonstram que houve perda considerável da eficiência da desnitrificação, em ambos os reatores, com a diminuição da relação $\mathrm{C} / \mathrm{N}$.

A cinética da desnitrificação, na presença de metano, diferiu significativamente daquela ocorrida na presença dos demais doadores de elétrons. Nesse caso, o modelo cinético de reação de ordem zero, para consumo de nitrato, mostrou-se mais adequado para representar os dados experimentais, tanto na presença, como na ausência de oxigênio.

Para o etanol e o metanol, as maiores eficiências de desnitrificação ocorreram para a relação C/N igual a 1,0 e, para o metano, ocorreu durante a operação na presença 
de oxigênio. Nestas condições, a desnitrificação foi completa após 50, 120 e 385 minutos, para os doadores de elétrons etanol, metanol e metano, respectivamente.

A operação dos reatores alimentados com metano, nesse experimento, permitiu constatar que a desnitrificação foi completa apenas na presença de oxigênio.

A análise da diversidade microbiana, através da técnica de PCR/DGGE, permitiu constatar que houve desenvolvimento significativo de microrganismos pertencentes ao Domínio Bacteria, em todos os reatores. A comparação dos padrões de bandas permitiu inferir que é provável que bactérias metanotróficas estivessem presentes em todos os reatores.

O lodo floculento formado em todos os reatores, ao longo do tempo de operação, apresentou grande diversidade de microrganismos pertencentes ao Domínio Bacteria, sendo a maior diversidade observada no reator alimentado com etanol, não havendo diferenças na diversidade de microrganismos pertencentes ao Domínio Archaea.

As populações de bactérias foram diferentes entre os reatores alimentados com etanol e metanol. No reator alimentado com metano, na presença de oxigênio, a maior parte dos padrões de bandas observados encontravam-se também presentes nos reatores alimentados com etanol e metanol.

Constatou-se ter havido mudanças nas populações de bactérias dos reatores alimentados com etanol e metanol, que foram decorrentes tanto da utilização dos doadores de elétrons específicos, como das variações da relação $\mathrm{C} / \mathrm{N}$. Em relação à população de arqueas, não foi observado haver dinamismo dessa população devido à utilização dos doadores de elétrons etanol e metanol, mas somente como conseqüência das variações nos valores de $\mathrm{C} / \mathrm{N}$.

\section{- Experimentos com reatores para estudo cinético}

Esses experimentos permitiram concluir que o processo de retirada do lodo dos reatores anóxicos, alimentados com etanol, metanol e metano, que se encontravam sob condições estáticas, seguido da submissão à elevada velocidade de agitação, não foi adequado para determinação dos parâmetros cinéticos intrínsecos. A desgranulação do lodo, bem como a mudança brusca nas condições físicas às quais os microrganismos encontravam-se adaptados, tiveram grande influência sobre o comportamento dos microrganismos desnitrificantes. 


\section{- Experimentos com reatores anóxicos alimentados com metano}

A desnitrificação através de metano ocorreu tanto na presença, como na ausência de oxigênio, confirmada através da produção de $\mathrm{N}_{2} \mathrm{O}$ e da diferença entre as populações bacterianas observadas, por DGGE, nos reatores alimentados com metano e com metano e oxigênio, em relação ao reator controle, que não recebeu adição de fonte exógena de carbono. Nos reatores que receberam suplementação com solução de metais, o $\mathrm{N}_{2} \mathrm{O}$ não foi detectado, o que indicou que a redução (assimilativa e/ou dissimilativa) de nitrato à amônia foi a rota metabólica de preferida, em substituição à desnitrificação.

Como o reator controle não recebeu fontes exógenas de carbono, concluiu-se que a desnitrificação ocorreu a partir da utilização de fontes endógenas de doadores de elétrons, uma vez que o nitrato foi completamente removido do reator e foi detectada a formação de $\mathrm{N}_{2} \mathrm{O}$.

O reator alimentado apenas com metano apresentou comportamento cinético de remoção de nitrato e de nitrito diferente dos demais. Nesse caso, o modelo de reações múltiplas irreversíveis, em série, permitiu melhor representar os dados experimentais. A remoção de nitrato seguiu reação de primeira ordem e a de nitrito, reação de ordem zero.

Para os reatores controle e alimentado com metano e oxigênio (nos quais ocorreu desnitrificação) e os alimentados com metano e metais e metano, metais e oxigênio (nos quais ocorreu a redução de nitrato à amônia), o consumo de nitrato seguiu reação de ordem zero, ou seja, a velocidade de conversão foi independente da concentração de nitrato no meio. Nesses casos, não foi possível obter ajuste do modelo cinético de reações em série, devido aos dados experimentais de nitrito.

O modelo cinético de reação de ordem zero foi ajustado, para efeito comparativo, aos dados experimentais de remoção nitrato do reator alimentado com metano. Constatou-se que a presença de oxigênio (reator com metano e oxigênio) tornou o processo de desnitrificação 30\% mais eficiente que o ocorrido no reator que recebeu apenas metano e foi operado na ausência de oxigênio.

Verificou-se que a resistência à transferência de massa exerce influência considerável sobre a cinética da desnitrificação, quando o metano é utilizado como doador de elétrons. Além disso, a velocidade de remoção de nitrito manteve-se inferior à de consumo de nitrato, indicando que a etapa de consumo de nitrito foi a limitante no processo reacional. 
Constatou-se que a maioria das populações microbianas, pertencentes ao Domínio Bacteria, presentes nos reatores com metano e metais e com metano, metais e oxigênio encontravam-se, também, presentes nos reatores com metano e com metano e oxigênio. Essa constatação pode ser indicativa da presença de microrganismos que fazem a redução dissimilativa ou assimilativa de nitrato à amônia, também nos reatores alimentados com metano, que não receberam metais.

A diferença entre a população de bactérias observada em todos os reatores alimentados com metano, quando comparadas com o reator controle, deve estar relacionada à seleção dos microrganismos pelo tipo de fonte de carbono que foi utilizada. É provável que bactérias metanotróficas tenham intermediado o processo de desnitrificação quando o metano foi utilizado como doador de elétrons.

A diversidade microbiana presente nos reatores com metano e com metano e oxigênio foi diferente do reator controle, principalmente devido à presença de duas bandas no gel de DGGE que podem estar relacionadas à presença de microrganismos desnitrificantes que utilizavam metano como única fonte de elétrons.

Foi constatado que houve desenvolvimento de microrganismos pertencentes ao Domínio Archaea em todos os reatores. Isto deve ter sido decorrente das condições favoráveis que se estabelecem no meio líquido, após o nitrato ser completamente reduzido.

Foi observado que tanto os microrganismos desnitrificantes, quanto os que realizaram o processo de redução de nitrato à amônia, foram tolerantes à presença de oxigênio. No entanto, a presença de metais influenciou fortemente a rota metabólica de redução de nitrato, sendo preferida a via de produção de nitrogênio amoniacal.

\section{- Ensaio de purificação}

As observações morfológicas permitiram constatar que, entre as amostras de lodo purificadas a partir dos reatores anóxicos alimentados com metano, independente da presença de nitrato ou de nitrito, predominaram bacilos, sendo que todas as células purificadas foram gram-negativas.

As amostras obtidas a partir do reator alimentado com metano, metais e oxigênio, purificadas na presença de nitrato e de nitrito, apresentaram visível 
crescimento de microrganismos após 24h, devendo, tais células, ser representativas de microrganismos aeróbios.

O ensaio para obtenção da cinética de crescimento celular, realizado para a amostra purificada a partir do reator alimentado com metano, metais e oxigênio, na presença de nitrato, indicou ser provável que a cultura purificada seja constituída por bactérias metanotróficas, devido ao fato de não ter havido, após 48 horas de ensaio, redução de nitrato tendo os ácidos fórmico e acético sido detectados no meio líquido.

A análise de PCR/DGGE dessas culturas, purificadas na presença de nitrato e de nitrito, indicou que algumas bandas foram observadas tanto na presença de nitrato, como na presença de nitrito. Além disso, diversidade considerável de bandas foi observada no gel de DGGE para ambas as amostras. 


\section{SUGESTÕES}

Sugere-se a realização de estudos mais aprofundados sobre as características do lodo de inóculo a ser utilizado em reatores desnitrificantes, visando o estabelecimento mais rápido de população desnitrificante. Em geral, tem-se utilizado lodo anaeróbio metanogênico, que deve passar por intenso processo de adaptação e seleção microbiana para adquirir as características de lodo predominantemente desnitrificante.

Sugere-se que a imobilização da biomassa desnitrificante seja realizada em materiais suporte. Observou-se, através da técnica de PCR/DGGE, que a população de bactérias encontrava-se em maior quantidade no lodo floculento, que se formou ao longo do tempo de operação, do que nos grânulos, sendo que a estrutura granular chegou a ser desfeita, em alguns casos.

No Brasil, sugere-se o uso de etanol como fonte externa de elétrons, uma vez que esse composto é produzido em grande escala no país a partir da cana de açúcar.

Quando doadores de elétrons específicos forem utilizados para promover o processo de desnitrificação, sugere-se que o cálculo da concentração do doador a ser introduzida nos reatores seja baseado na capacidade que cada composto possui em doar elétrons (relação estequiométrica) e não em valores fixos de relação C/N.

Sugere-se o desenvolvimento de novas configurações de reatores que permitam a introdução do gás metano na fase líquida e minimizem a resistência à transferência de massa, a fim de viabilizar a utilização do metano como doador de elétrons para a desnitrificação. Além disso, sugere-se a utilização direta do biogás produzido em reator anaeróbio, utilizado para tratamento de esgotos, como fonte de elétrons para reator desnitrificante.

Sugere-se a utilização de primers específicos, que identificam a presença de genes envolvidos na desnitrificação e contém regiões de DNA altamente conservadas, como $\mathrm{NaR}, \mathrm{NiR}, \mathrm{NOR}, \mathrm{N}_{2} \mathrm{OR}$, em estudos moleculares sobre bactérias desnitrificantes. 
Sugere-se estudar, em maior profundidade, o metabolismo das bactérias metanotróficas, uma vez que a presença desses microrganismos, em reatores anaeróbios que produzem gás metano, parece ser comum.

Sugere-se que seja dada continuidade aos estudos para obtenção da cinética de crescimento celular da provável cultura de bactérias metanotróficas obtida neste trabalho, com o objetivo de se obter a seqüência de DNA das culturas purificadas. 


\section{REFERÊNCIAS BIBLIOGRÁFICAS}

ALEXANDER, M. (1982). Most-probable-number method for microbial populations In: Methods of Soil Analysis. Part 2. Chemical and Microbiological Properties. Tiedje, J. M. (editor). $2^{\text {nd }}$ ed. Madson, Wisconsin: USA, p-815 - 820.

ARAÚJO, J. C. (1995). Caracterização e evolução do biofilme em reator anaeróbio de leito fluidificado alimentado com esgoto sanitário sintético. 158p. Dissertação (Mestrado) - Escola de Engenharia de São Carlos, Universidade de São Paulo, São Carlos. 1995.

AVERILL, B. A; TIEDJE, J. M. (1982). The chemical mechanism of microbial denitrification. FEMS Microbiology. 138: 8-12.

BAILEY, J.E.; OLLIS, D.F. (1986) Biochemical Engineering Fundamentals. 2nd edition. McGraw-Hill, New York.

BANDPI, A. M.; ELLIOTT. (1998). Groundwater denitrification with alternative carbon source. Water Science technology. 38 (6): 237-243.

BANDPI, A. M.; ELLIOTT, D. J.; MAZDEH, A. M. (1999). Denitrification of groundwater using acetic acid as a carbon source. Water science technology. 40 (2): 5359.

BENEFIELD, L. D.; RANDALL, C. W. (1980). Biological process design for wastewater treatment. United States of America. Prentice -Hall, Inc.

BILANOVIC, D. et al. (1999). Denitrification under high nitrate concentration and alternating anoxic conditions. Water research. 33 (15): 3311-3320.

BLACK, J. G. (2002).Microbiologia: Fundamentos e Perspectivas. Quarta edição. Editora Guanabara. Rio de Janeiro - RJ. 
BOTHE, H. et al. (2000). Molecular analysis of ammonia oxidation and denitrification in natural environments. FEMS Microbiology Reviews. 24: 673-690.

BURGESS, J. E.; QUARMBY, J.; STEPHENSON, T. (1999). Role of micronutrients in activated sludge-based biotreatment of industrial effluents. Biotechnology Advances. 17: 49-70.

CALLADO, N. H. (2001). Reatores seqüenciais em batelada em sistema anaeróbio / aeróbio tratando esgoto sanitário sintético. 221p. Tese (Doutorado) - Escola de Engenharia de São Carlos, Universidade de São Paulo, São Carlos. 2001.

CALLADO, N. H.; FORESTI, E. (2001). Removal of organic carbon, nitrogen and phosphorus in sequential batch reactors integrating the aerobic/anaerobic processes. Water Science and Technology. 44 (4): 263-270.

CARR, G. J.; FERGUSON, S. J. (1990). The nitric oxide reductase of Paracoccus denitrificans. Biochemical Journal. 269: 423-429.

CASEY, T. G.; WENTZEL, M. C.; EKAMA, G. A. (1999a). Filamentous organism bulking in nutrient removal activated sludge systems. Paper 9: Review of biochemistry of heterotrophic respiratory metabolism. Water Science and Technology. 25 (4): 409424.

CASEY, T. G.; WENTZEL, M. C.; EKAMA, G. A. (1999b). Filamentous organism bulking in nutrient removal activated sludge systems. Paper 10: Metabolic behavior of heterotrophic facultative aerobic organisms under aerated/unaerated conditions. Water Science and Technology. 25 (4): 425-442.

CATTONY, E. B. (2001). Avaliação da diversidade microbiana e das características físico-químicas de solo submetido ao cultivo de cana-de açúcar. 80p. Dissertação (Mestrado) - Escola de Engenharia de São Carlos, Universidade de São Paulo, São Carlos. 2001.

CHIU, Y. C.; CHUNG, M. S. (2003). Determination of optimal DQO/nitrate ratio for biological denitrification. International Biodeterioration \& Biodegradation. 51: 43-49.

CORRÊA, C. L.; PEDROSO, R. C. (1997). Headspace gás chromatography with capillary column for urine alcohol determination. Journal of chromatography b. 704: 365-368.

COSTA, C. et al. (2000). Denitrification with methane as electron donor in oxygen- 
limited bioreactors. Applied Microbiology and Biotechnology. 53: 754-762.

DABERT, P. et al. (2002). Contribution of molecular microbiology to the study in water pollution removal of microbial community dynamics. Re/Views in Environmental Science \& Bio/Technology. 1: 39-49.

DSM - Scientific services of culture collections. Curso ministrado na Fundação Tropical de Pesquisas e Tecnologia André Tosello, Campinas - SP (1991).

EISENTRAEGER, A. et al. (2001). Denitrification of groundwater with methane as sole hydrogen donor. Water research. 35 (9): 2261-2267.

ETCHEBEHERE, C. et al. (2000). Characterization of the microflora of a denitrifiying reactor by standard culture dependent techniques and new molecular cultureindependent tools. In: VI OFICINA E SEMINÁRIO LATINO-AMERICANO DE DIGESTÃO ANAERÓBIA. Anais, Recife. p143-149.

FORESTI, E. et al. (1999). Fundamentos do tratamento anaeróbio. In: Tratamento de esgotos sanitários por processo anaeróbio e disposição controlada no solo. Campos, J. R. (coordenador). Rio de Janeiro. ABES. Projeto PROSAB.

GUYNOT, M. E. et al. (1998). Microflora of dissimilative nitrate reduction in a denitrifying reactor. Applied Microbiology and Biotechnology. 50: 396-400.

GYLSBERG, B. et al. (1998). Dynamics of $\mathrm{N}_{2} \mathrm{O}$ production from activated sludge. Water Research. 32 (7): 2113-2121.

HER J. J.; HUANG, J. S. (1995). Influences of carbon source and C/N ratio on nitrate/nitrite denitrification and carbon breakthrough. Bioresource technology. 54: 4551.

HORZ, H. P. et al. (2002). Activity and community structure of methane-oxidising bacteria in a wet meadow soil. FEMS Microbiology Ecology. 41: 247-257.

HOUBRON, E.; TORRIJOS, M.; CAPDEVILLE, B. (1999). An alternative use of biogas applied in water denitrification. Water Science and Technology. 40 (8): 115-122.

ISLAS-LIMA S.; THALASSO, F.; GOMES, J. (2002). Evidence of anoxic methane oxidationcoupled to denitrification. Anais de trabalhos orais. VII Taller Y Simposio Latinoamericano Sodre Digestión Anaerobia. Mérida, Yucatán - México.

JERIS, J. S.; McCarty (1965). The biochemistry of methane fermentation using $\mathrm{C}^{14}$ tracers. Journal Water Pollution Control Federation. 37: 178. 
JIANPING, W. et al. (2003). The denitrification of nitrate contained wastewater in a gasliquid-solid three-phase flow airlift loop bioreactor. Biochemical Engineering Journal. 15: 153-157.

KUDO, Y. et al. (1997). Methanogen flora of paddy soils in japan. FEMS Microbiology Ecology. 22: 39-48.

LEHNINGER, A. L. (1975) Biochemistry. $2^{\text {nd }}$ edition. Worth Publishers Inc, New York.

LEVENSPIEL, O. (1999) Chemical Engineering Reactor. $3^{\text {rd }}$ edition. John Wiley \& Sons, New York.

LOUZEIRO, N. R. et al. (2002). Methanol-induced biological nutrient removal kinetics in a full-scale sequencing batch reactor. Water Research. 36: 2721-2732.

MADIGAN, M. T.; MARTINKO, J. M.; PARKER, J. (1997). Brock Biology of Microorganisms. $8^{\text {th }}$ edition. Prentice Hall.

MCELDONEY, S.; HARDMAN, D. J.; WAITE, S. (1993). Pollution: ecology and biotreatment. England. Logman Scientific \& Technical, 322p.

MECHSNER K.; HAMER, G. (1985). Denitrification by methanotrophic/methylotrophic bacterial association in aquatic environment. In: Denitrification in the Nitrogen Cycle. Golterman, L. H. (editor). Plenum Publisher Corporation. New York.

MELVIN, A. N. G.; HOBSON T. W.; (1994). Identification of anaerobic digester bacteria using a polymerase chain reaction method. Bioresource Technology. 47: 73-80. Nation (1983). A new method using hexamethyldisilasane for preparation of soft tissues for scanning electron microscopy. Staining Technology. 58: 347-351.

NIELSEN, T. A. et al. (1999) Identification of a novel group of bacteria in sludge from a deteriorated biological phosphorus removal reactor. Applied and Environmental Microbiology. 65 (3): 1251-1258.

NYBERG, U.; ANDERSON, B.; ASPEGREN, H. (1996). Long-term experiences with external carbon sources for nitrogen removal. Water science technology. 33 (12): 109116.

OYAIZU, H. et al. (2000) Analysis of complex microbial community in soil and wastewater treatment processes by cloning method. In: The International Symposium of 
the COE, Center of Excellence, Project on Establishment and Evaluation of Advanced Water Treatment Technology Systems Using Functions of Complex Microbial Community. Tokyo - Japan. p.48 - 59.

POCHANA, K.; KELLER, J. (1999). Study of factors affecting simultaneous nitrification and denitrification (SND). Water science technology. 39 (6): 61-68.

RAJAPAKSE, J. P.; SCUTT, J. E. (1999). Denitrification with natural gas and various new growth media. Water Research. 33 (18): 3723-3734.

ROS, M. (1995). Denitrification kinetics in an activated sludge system. Water science technology. 32 (9-10): 323-330.

ROSADO, A. S. et al. (1997). Molecular microbial ecology: a minireview. Revista de Microbiologia. 28: 135-147.

SAKAMOTO, I. K. (2001). Comparação da estrutura de comunidades microbianas presentes em sistemas de lodos ativados modificados para remoção biológica de fósforo em excesso, utilizando a técnica de eletroforese em gel de gradiente desnaturante (DGGE). 162p. Tese (Doutorado) - Escola de Engenharia de São Carlos, Universidade de São Paulo, São Carlos. 2001.

SANTOS, S. G. et al. (2002a). Comparative research on the use of methanol, ethanol and methane as electron donors for denitrification. Anais de trabalhos orais. VII Taller Y Simposio Latinoamericano Sodre Digestión Anaerobia. Mérida, Yucatán - México.

SANTOS, S. G. et al. (2002b). Utilização de cromatografia para acompanhamento de sistema desnitrificante na quantificação de baixas concentrações de fontes de carbono específicas (metanol e etanol). In: XXVIII Congresso Interamericano de Ingeniería Sanitaria y Ambiental. AIDIS. Anais, Cancun - México.

SHAPLEIGH, J. P.; PAYNE, W. J. (1985). Differentiation of $c d_{1}$ cytochrome und copper nitrite redutase production in denitrifiers, FEMS Microbiology. Lett. 26: 275279.

SHIEH, W. K.; MULCAHY, L. T. (1986). Experimental determination of intrinsic kinetic coefficients for biological wastewater treatment systems. Water science technology. 18: 1-10.

SILVEIRA, B. I. (1996). Cinética química das reações homogêneas. Editora Edgard Blücher LTDA. São Paulo, Brasil. 
SOLOMON, E. P. et al. (1993) Biology. $3^{\text {th }}$ ed. Saunders College Publishing. Flórida, USA.

SOUSA, J. T.; FORESTI, E. (1999). Utilização de lodo anaeróbio como fonte externa de carbono no processo de desnitrificação de águas residuárias. Revista Brasileira de Engenharia Agrícola e Ambiental. 3 (1): 69-73.

STANDARD METHODS FOR THE EXAMINATION OF WATER AND WASTEWATER (1998). 19 $19^{\text {th }}$ ed. Amer. Public Health Assoc., Americ. Water Works Association, Water Pollution Control Federation, Washington, D.C., 1134p.

SVENNING, M. M. et al. (2003). Isolation of methane oxidising bacteria from soil by use of a soil substrate membrane system. FEMS Microbiology Ecology. 44: 347-354.

THALASSO, F. et al. (1997). The use of methane as a sole carbon source for wastewater denitrification. Water Research. 31 (1) 55-60.

TIEDJE, J. M. (1988) Ecology of denitrification and dissimilatory nitrate reduction to ammonium. In: Biology of Anaerobic Microorganisms. Zehnder, J. B. (editor). John Wiley \& Sons, New York.

VAN HAANDEL, A.; MARAIS, G. (1999). O comportamento do sistema de lodo ativado, teoria e aplicações para projetos e operação. Campina Grande-PB. Epgraf.

VIEIRA, L. G. T. (1996). Estimativa de parâmetros cinéticos intrínsecos de utilização de substrato por lodo anaeróbio imobilizado. 58p. Dissertação (Mestrado) - Escola de Engenharia de São Carlos, Universidade de São Paulo, São Carlos. 1996.

VIEIRA, L. G. T. (2000). Desenvolvimento de sistema misto (anaeróbio/aeróbio) de leito fixo para remoção de nitrogênio de esgoto sanitário pré-tratado em reator anaeróbio. 144p. Tese (Doutorado) - Escola de Engenharia de São Carlos, Universidade de São Paulo, São Carlos. 2000.

YOSHINARI, T.; KNOWLES, R. (1976). Acetylene inhibition of nitrous oxide reduction by denitrifying bacteria. Biochem. Biophys. Res. Commun.,69,p.705-10.

ZHAO, H. W. et al. (1999). Controlling factors for simultaneous nitrification and denitrification in two-stage intermittent aeration process treating domestic sewage. Water research. Vol. 33, No. 4, pp. 961-970. 
ZINDER, S. H.; SOWERS, K. R.; FERRY, J. G. (1984). Methanosarcina thermophila s. Nov. a termophilic, acetotrofic, methane-producing bacterium. International Journal of Systematic Bacteriology. 35: 522 - 523. 


\section{APÊNDICES}

\subsection{Apêndice 1 - Resultados de Extração de DNA}

Neste apêndice encontram-se apresentados os resultados de extração de DNA das amostras de lodo dos reatores anóxicos comparativos. No passo 16 da etapa de extração de DNA (item 5.7.1.1) a amostra foi dividida em 3 tubos de eppendorf para ser submetida a etapa de precipitação do DNA. Dessa forma, cada amostra de lodo submetida ao processo de extração resultou em 3 tubos contendo DNA representativo de tal amostra, denominados nas Figuras 45 e 46 de $\boldsymbol{a}, \boldsymbol{b}$ e $\boldsymbol{c}$. Isso não quer dizer que as amostras foram extraídas em triplicata. Em alguns casos, a quantidade obtida de DNA foi muito pequena, sendo necessário juntar as amostras $\boldsymbol{a}, \boldsymbol{b}$ e $\boldsymbol{c}$ em uma única amostra denominada $\boldsymbol{a}$.
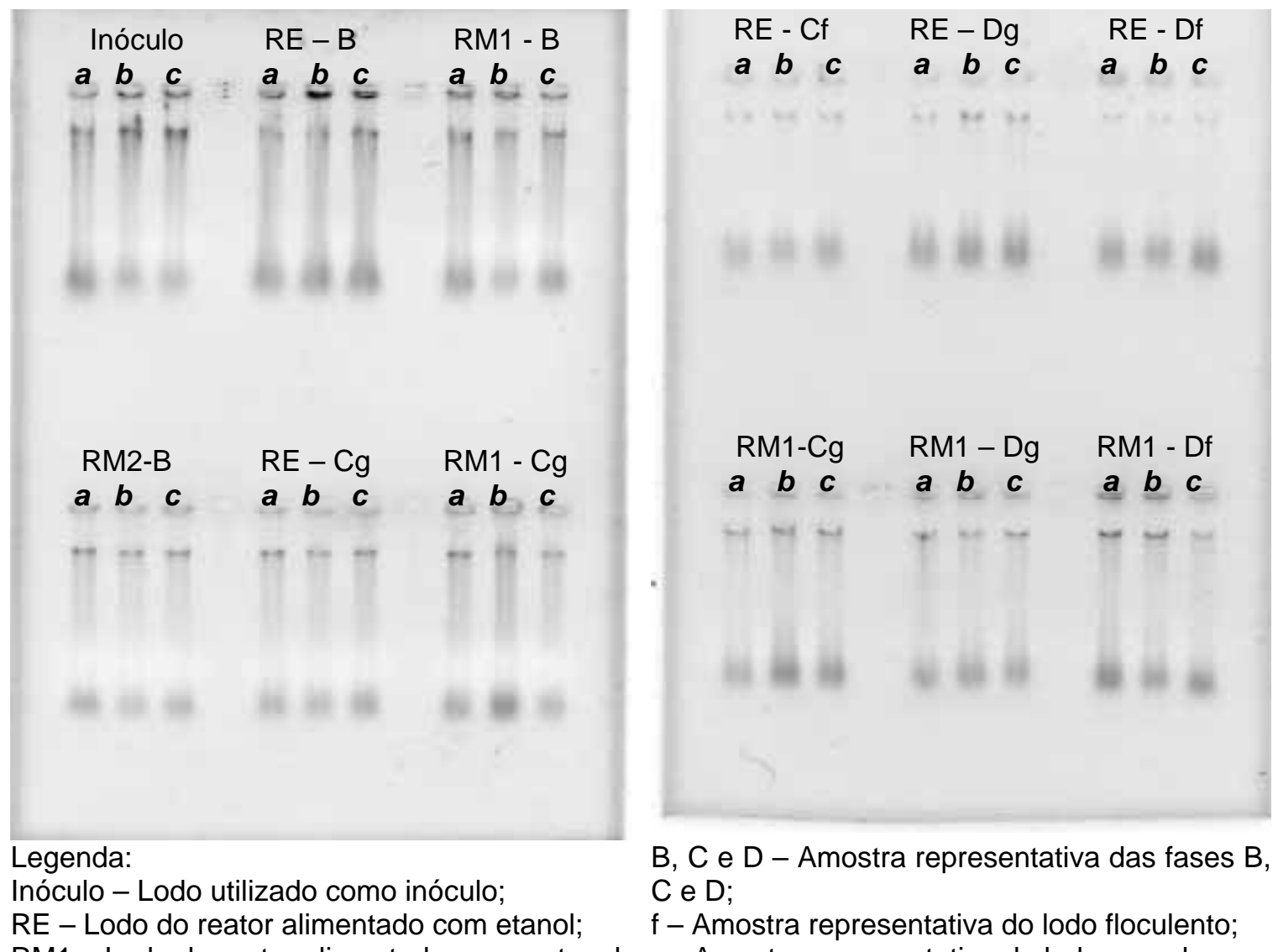

B, C e D - Amostra representativa das fases B, C e D;

$\mathrm{RE}$ - Lodo do reator alimentado com etanol; $\quad \mathrm{f}$ - Amostra representativa do lodo floculento; RM1 - Lodo do reator alimentado com metanol; g - Amostra representativa do lodo granular.

Figura 44. Resultado do processo de extração de DNA das amostras de lodo dos reatores anóxicos comparativos, alimentado com etanol, metanol e metano, nas fases B, C e D. 


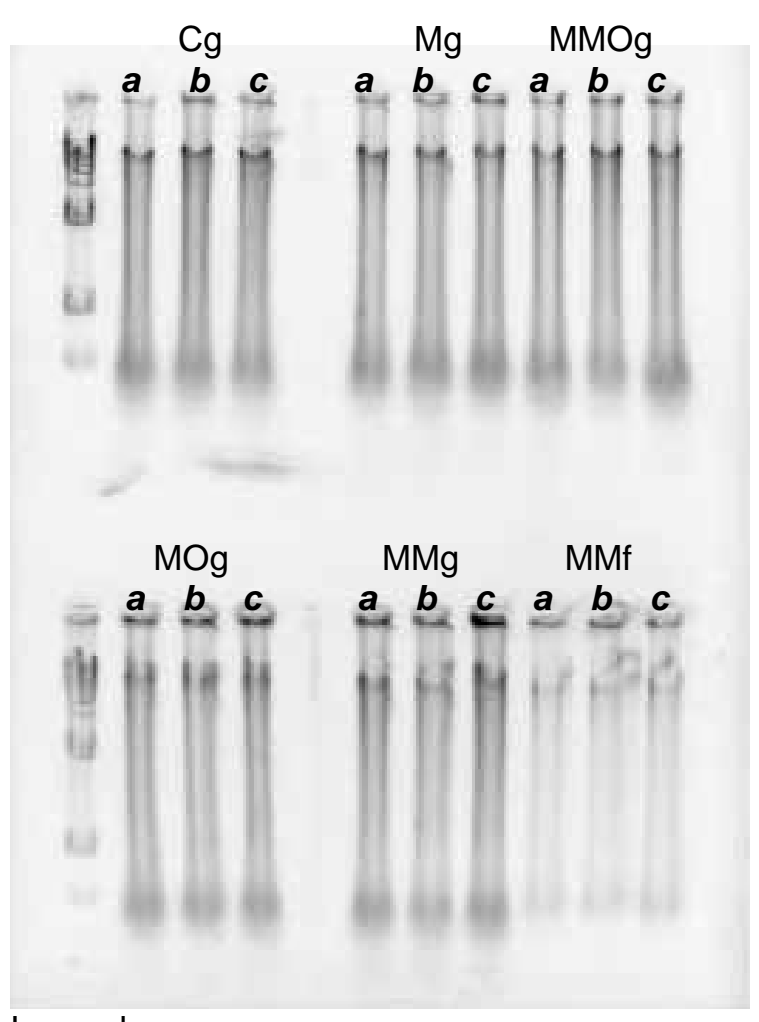

Legenda:

M - Lodo do reator alimentado com metano;

MM - Lodo do reator alimentado com metano e metais;

$\mathrm{MO}$ - Lodo do reator alimentado com metano oxigênio;

Figura 45. Resultado do processo de extração de DNA das amostras de lodo dos reatores anóxicos alimentados com metano, M, MO, MM, MMO e C.

MMO - Lodo do reator alimentado com metano, metais e oxigênio;

C - Lodo do reator controle;

$\mathrm{f}$ - Amostra representativa do lodo floculento;

g - Amostra representativa do lodo granular. $\mathrm{P} 1-\mathrm{MMO}_{3} \quad \mathrm{CP} 2-\mathrm{MMO}_{2} \quad \mathrm{Mf}$ $\underline{a} \underline{b} \quad a \underline{b} \quad a$ MOf MMOf a.b. a

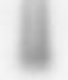




\subsection{Apêndice 2 - Produtos de PCR}

Neste apêndice encontram-se apresentados os produtos das reações de PCR, em que as amostras de DNA foram amplificadas através da utilização de primers para os Domínios Bacteria e Archaea.

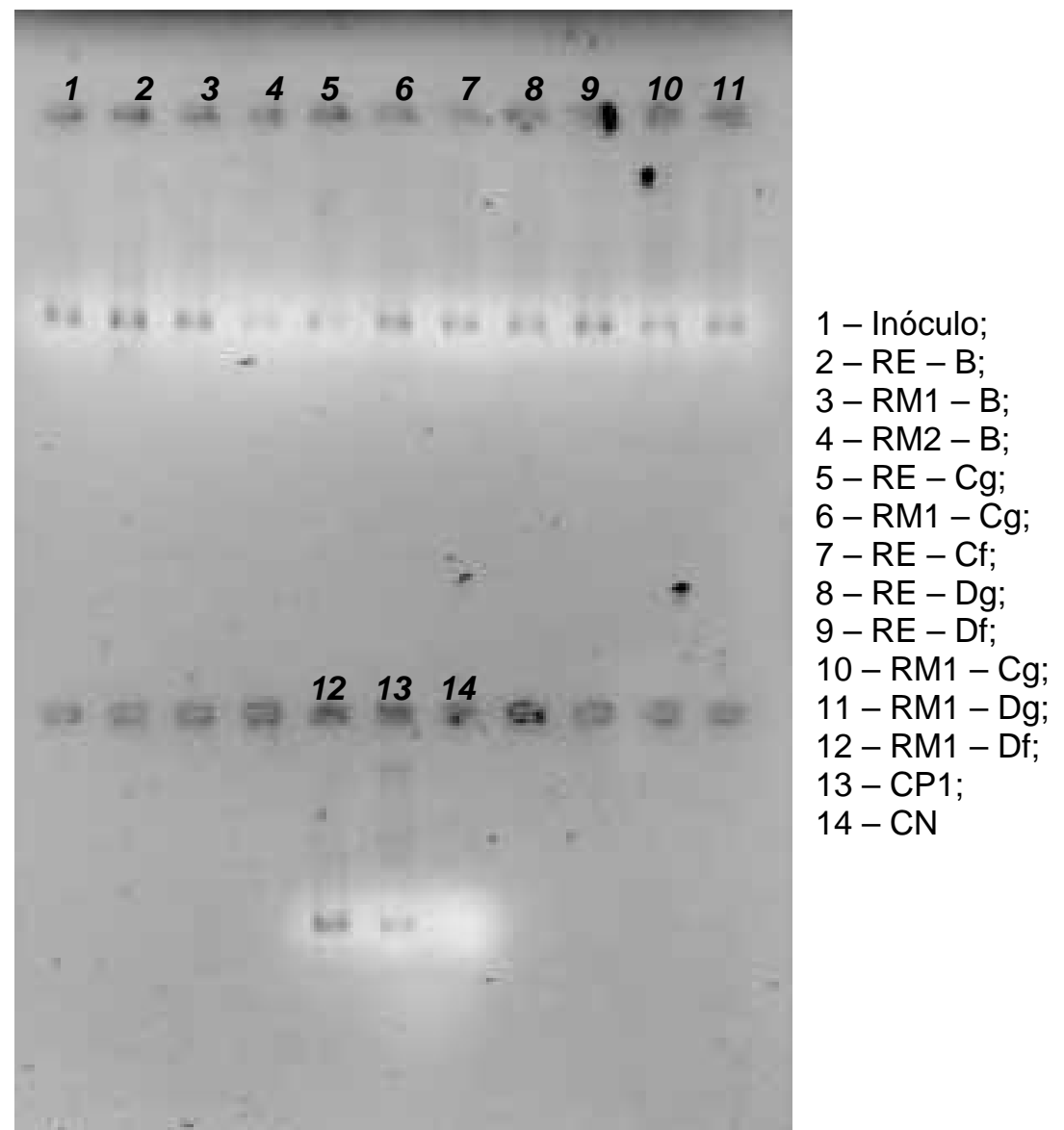

Figura 46. Produto da amplificação, por PCR, para o Domínio Bacteria, das amostras de lodo dos reatores RE, RM1 e RM2, nas fases $B, C$ e D. 


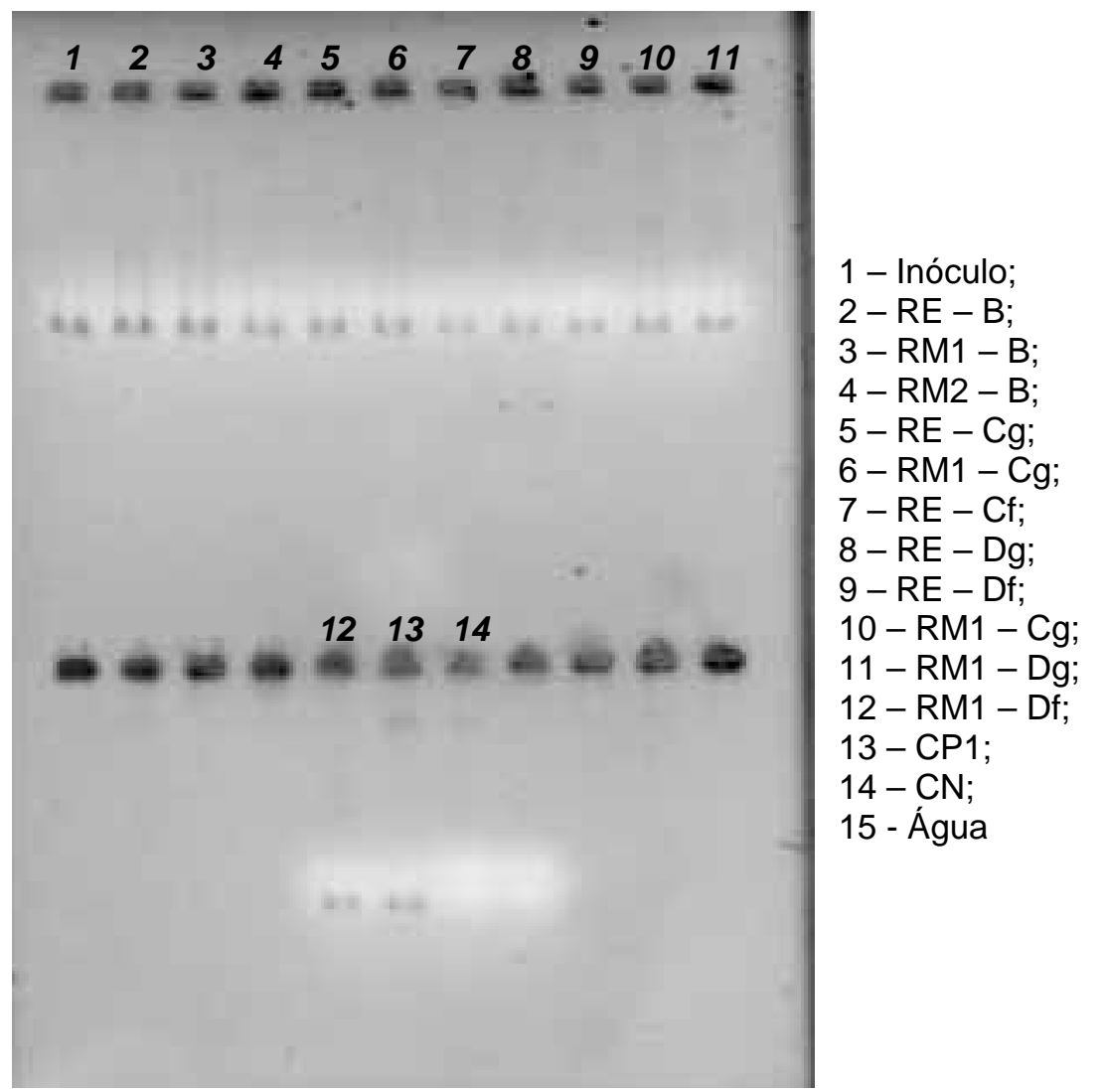

Figura 47. Produto da amplificação, por PCR, para o Domínio Archaea, das amostras de lodo dos reatores RE, RM1 e RM2, nas fases $B, C$ e D.

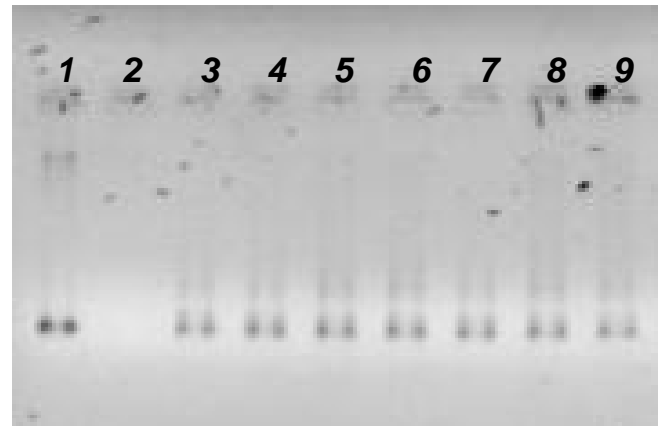

$$
\begin{aligned}
& \text { 1-Inóculo; } \\
& \text { 2-CN; } \\
& \text { 3-CP1; } \\
& \text { 4-CP2; } \\
& \text { 5-M; } \\
& \text { 6-MO; } \\
& \text { 7-MM; } \\
& \text { 8-MMO; } \\
& \text { 9-C. }
\end{aligned}
$$

Figura 48. Produto da amplificação, por PCR, para o Domínio Bacteria, das amostras de lodo dos reatores anóxicos alimentado com metano, M, MO, MM, MMO e C.

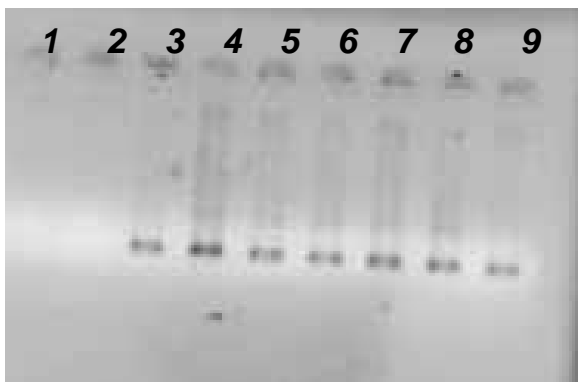

$$
\begin{aligned}
& \text { 1-CN1; } \\
& \text { 2-CN2; } \\
& 3 \text { - CP; } \\
& \text { 4-Inóculo; } \\
& \text { 5-M; } \\
& \text { 6-MO; } \\
& 7 \text {-MM; } \\
& \text { 8-MMO; } \\
& \text { 9-C. }
\end{aligned}
$$

Figura 49. Produto da amplificação, por PCR, para o Domínio Archaea, das amostras de lodo dos reatores anóxicos alimentado com metano, M, MO, MM, MMO e C. 